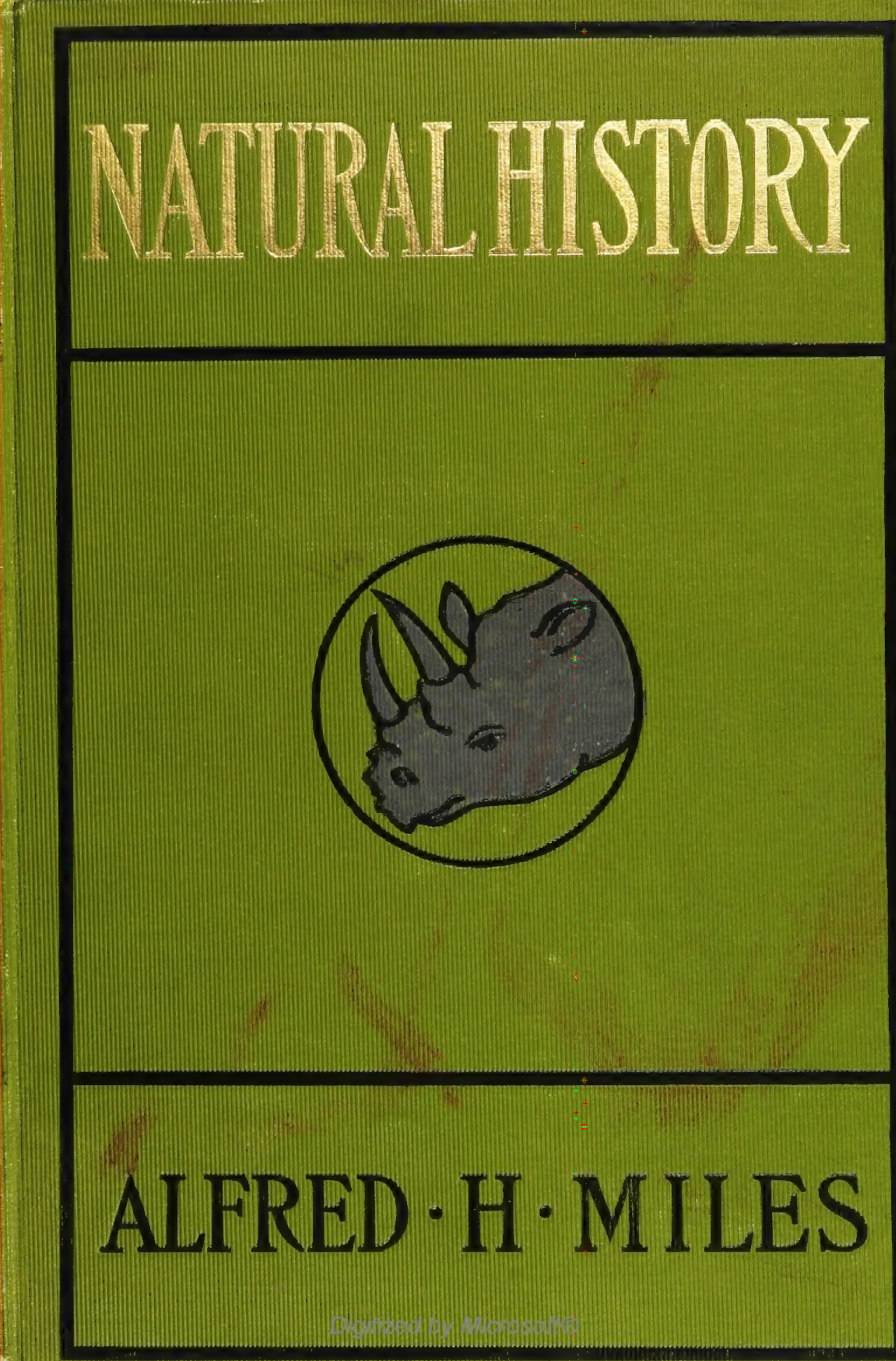


QH

45

M63

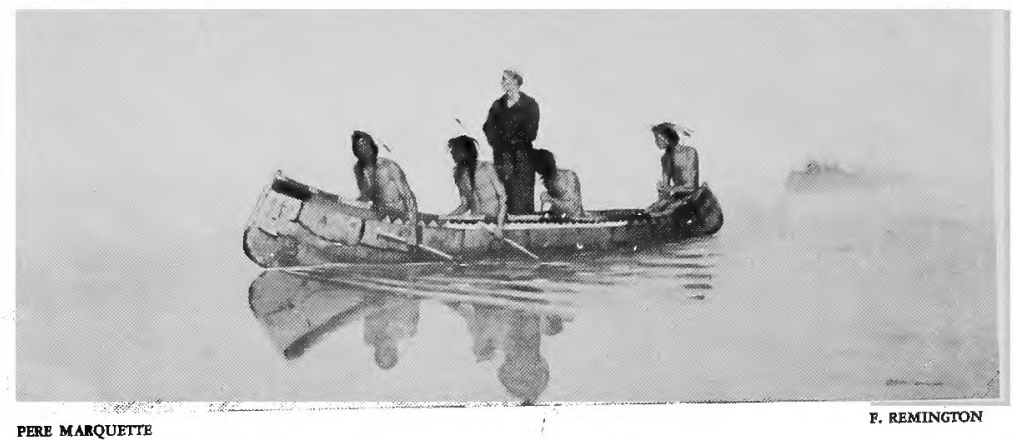

EX LIBRIS ROBERT E. TREMAN

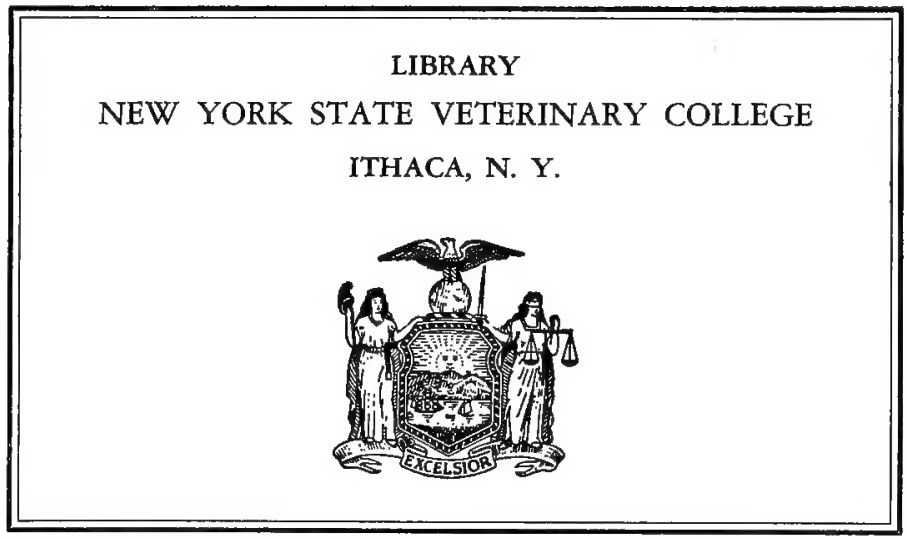




\section{Date Due}
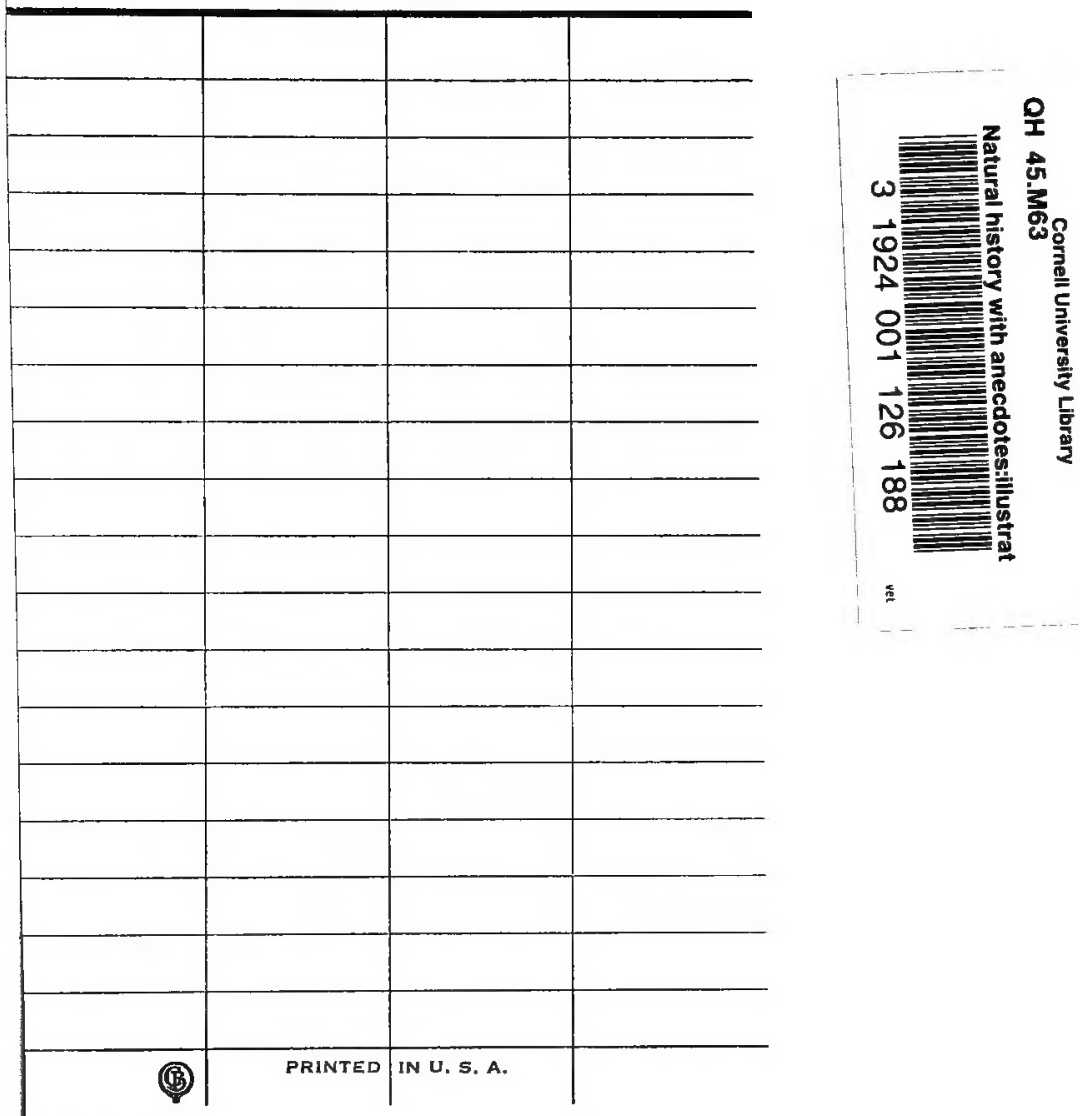
This book was digitized by Microsoft Corporation in cooperation with Cornell University Libraries, 2007. You may use and print this copy in limited quantity for your personal purposes, but may not distribute or provide access to it (or modified or partial versions of it) for revenue-generating or other commercial purposes. 


\section{Cornell University Library}

The original of this book is in the Cornell University Library.

There are no known copyright restrictions in the United States on the use of the text. 


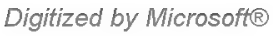




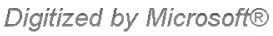




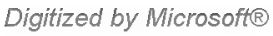




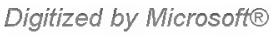




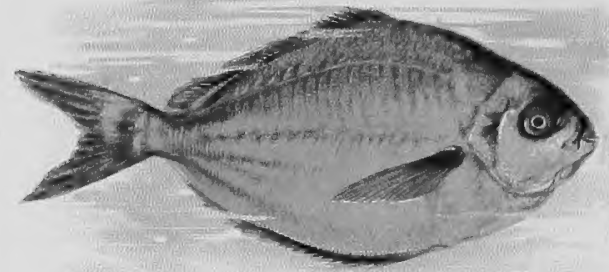

BUTTERFISH
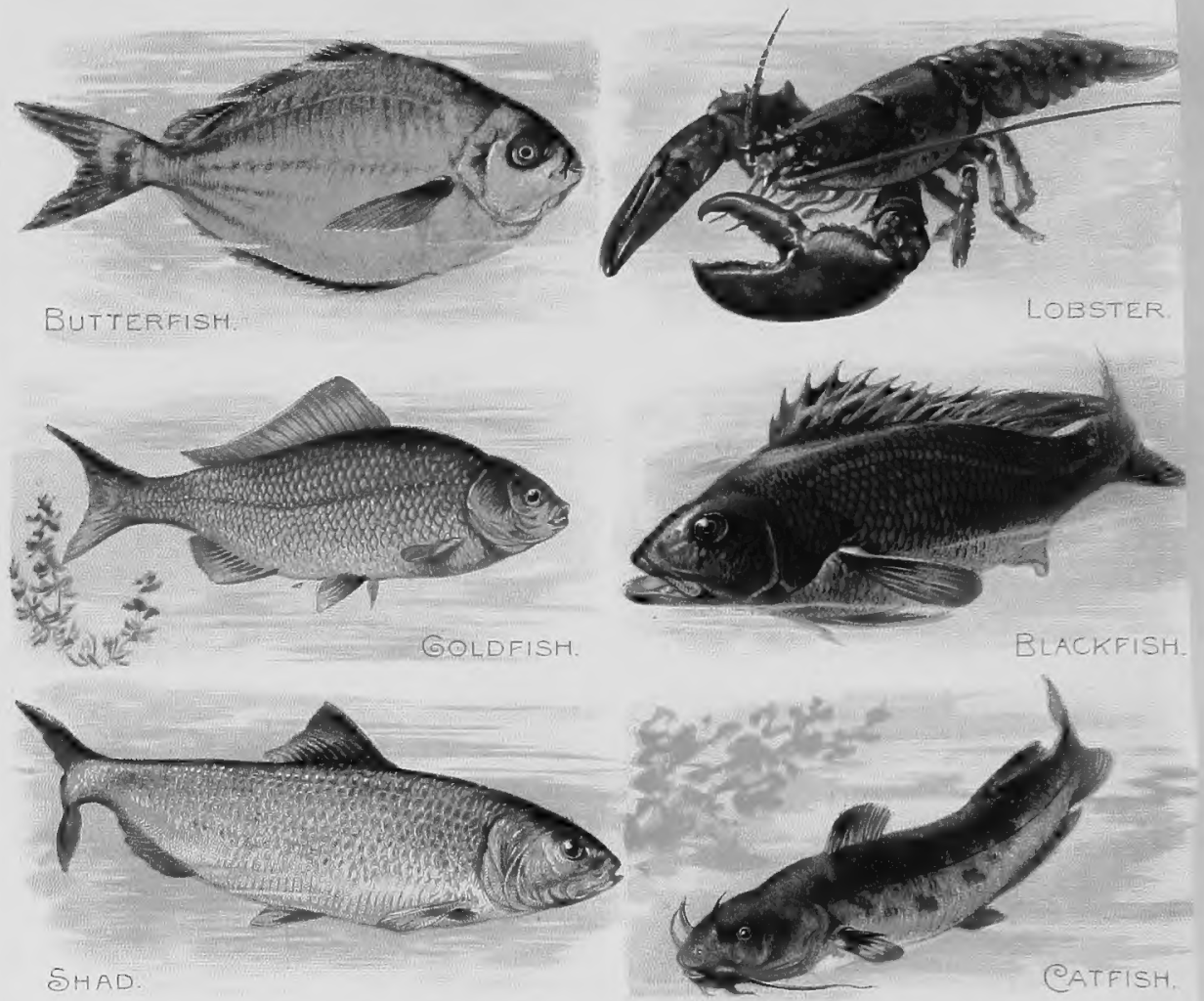

SHAD

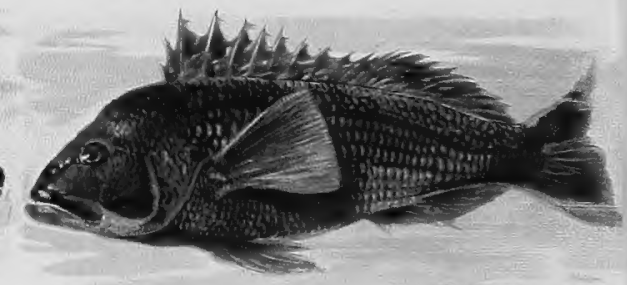

SEAROBIN

SEABASS.

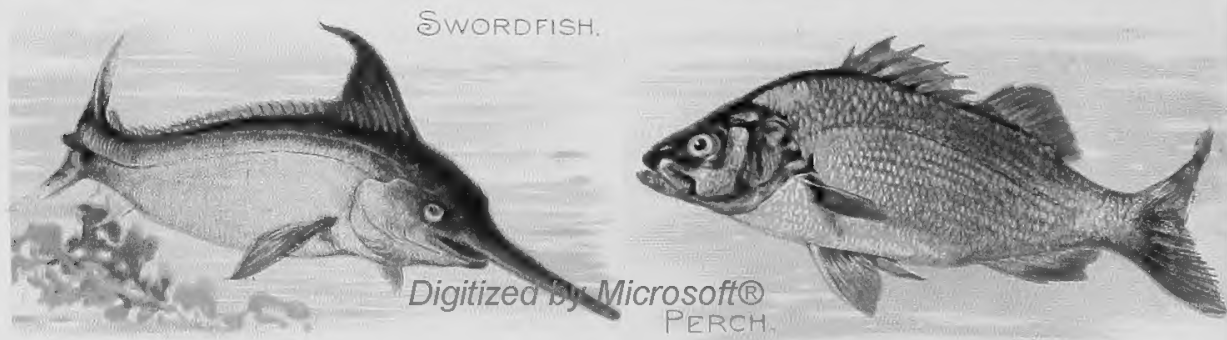


Digitized by Microsofte 
Digitized by Microsofte 


\title{
NATURAL HISTORY
}

\section{WITH ANECDOTES}

\section{ILLUSTRATING}

THE NATURE, HABITS, MANNERS AND CUSTOMS oF ANIMALS, BIRDS, FISHES, REPTILES, INSECTS, ETC., ETC., ETC.

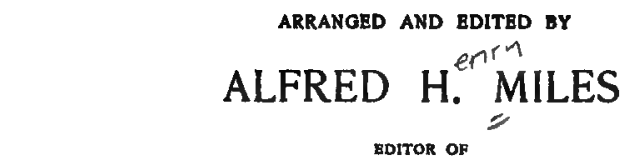

"The Poets and the Poetry of the Contury," "soor Anocdotes."

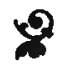

\author{
NEW YORK \\ DODD, MEAD \& COMPANY \\ PUBLISHERS
}




$$
\begin{aligned}
& \text { QH } \\
& 45 \\
& M 63
\end{aligned}
$$

Copyright, 189s,

BY

Dodd, Mead and Company.

All rights reserved.

NYS 10078

IRR 


\section{P R E F A C E.}

Illustrations are like windows to the house of knowledge. They let light in upon the understanding and they facilitate the outlook upon truth and beauty. To illustrate is to help one sense by the use of another, to reason by analogy and to teach the unknown by the known. When definition fails, illustration often carries conviction, and the most successful teachers are those who make the best use of sound and telling illustrations. How many lessons would have been wholly forgotten by us, but for the illustrations which made their meanings clear and left their truths for ever in our minds?

The book of nature is full of illustrations which help the understanding of the book of life, and no illustrations are more valuable and fascinating, whether as revelations of the order and habits of nature herself, or as parallels and parables, full of suggestive application to the social and moral life of humanity, than those afforded by the study of Natural History.

To gather into a convenient volume Illustrative Anecdotes of Natural History, which shall throw light upon the study of Animal Life, for those pursuing it for its own sake, and help to the understanding of Nature herself is the primary . object of this work, while it is hoped that it may serve a 
secondary purpose of no small utility, in suggesting social and morál parallels.

With a view to its first purpose the illustrations are classified in order as those of Mammals, Birds, Reptiles, Fishes, etc., etc., and as much knowledge of Natural History as can be conveyed in anecdote form has been attempted. The book will thus, it is hoped, be a valuable aid to the teacher of Natural History, as a manual of illustrations for his lessons, as well as full of interest to the general reader, who may not wish to devote the time necessary to more exhaustive scientific study.

A. H. M. 


\section{LIST OF COLORED PLATES.}

\section{ANIMALS.}

Plate I. Gorilla. Ourang-Outang.

Plate 2. Galago. Aye Aye.

Plate 3. Lion. Cheetah.

Plate 4. Aard Vark. Blotehed Gennet.

Plate 5. Jaguar. Cacomixle.

Plate 6. Leopard. Lynx.

Plate 7. Fox Terriers. Puppies.

Plate 8. Polar Bear. Ermine.

Plate q. Rhinoceros. Camel.

Plate ro. Elephant. Giraffe.

Plate xx. Zebra. Bison.

Plate xa. Beaver. Alpine Hare.

Plate s3. Tatou, Kangaroo.

\section{BIRDS.}

Plate 14. Sepoy Finch. Red-Headed Bunting. Chinese Bulbul. Canary Bird. Brazilian Tanager. Bell Bird. Orchard Oriole. Blue Bullinch. Java Grosbeak. Nightingale.
Plate 15. Emen Wren. Stitch Bird. Araguira. Whistling Thrush. Pastor. Parrot Finch. Swallow Dicaecum. Golden Oriole. Rosebreasted Grosbeak. Painted Bunting.

Plate r6. Kinglet. Scarlet Finch. Brown Thrasher. Mariposa. Huia. Madagascar Grosbeak. Crested Sparaetes. Mino Bird. Maryland Yellow Throat. Yurple-breasted Chatterer.

Plate 17. Shaft-tailed Bunting. Linnet. Piping Crow-strike. Pine Grosbeak. Audubon's Warbler. Thrush. Amandava. Yellow-head. Crested Malimbus, Saddle-back.

\section{FISHES.}

Plate 18. Spanish Mackerel. Mackerel. Weakfish. Herring. Bluefish. Codfish. Crab. Porgy. Eel. Whitefish.

Plate 19. Butterfish. Catfish. Goldfish. Blackfish. Shad. Lobster. Sea-robin. Sea-bass. Swordfish. Perch.

Plate 20. Carp. Yellow Perch. Sar. dine. Sawfish. Salmon. Sunfish. Brook Trout. Blowfish. Striped Bass. Moonfish. 
Digitized by Microsofte 


\section{CON T E N T S}

\section{INTRODUCTION}

Science, $x$

The Kingdoms of Nature, I

Zoology, 2

Classification, 2

\section{Class I.-Mammalia}

ORDER I

PRIMATES

SUB-ORDER I

Man-Shaped Animals

The Ape Family, 3

The Gorilla, 4

Ancestors of the Gorilla, 4

A Gorilla Hunt, 5

Du Chaillu's First Gorilla, 7

A Young Gorilla, 9

Gorilla Superstitions, 10

The Chimpanzee, II

Docility and Sagacity of Chimpanzee, II

The Orang-Utan, $x 2$

Habits of Orang-Utan, 12

Walk of Orang-Utan, 13

Strength of Orang-Utan, I4

Docility of Orang-Utan, 14

Orang-Utan's Intelligence, I5

" " Affection, I5

The Maternal Instinct, 16

Gibbons, or Long-Armed Apes, 17

Monkeys, 18

The Sacred Monkeys, 18

Long-nosed Monkey, rg

Cheek-pouched Monkeys, I9

The Baboon, I9

Arabian Baboon, 20

Baboon's Imitative Faculty, 20
The Chackma Baboon, 2r

Baboon's Utility, 2I

The Tame Baboon, 22

Baboon's Cunning, 22

" Loyalty, 24

“ Intelligence, 24

The Bonnet Monkey, 25

Indian Monkeys, 25

The Monkey Outdone, 27

The Monkey Aroused, 29

Monkey's Affection, 30

American Monkeys, $3 \circ$

The Capuchin Monkey, 30

The Spider Monkeys, $3^{\circ}$

The Howling Monkeys, 3I

The Bearded Saki, 3 I

The Douroucouli, 32

The Marmosets, 32

\section{SUB-ORDER II \\ The LeMURS}

T'he Tarsier, 33

The Aye-Aye, 33

ORDER II

WING-HANDED ANIMALS

Bats, 35

The Common English Bats, 36

The Vampire Bat, 36

A Traveller's Experience, 37

Megaderma Lyra, $3^{8}$

\section{ORDER III}

INSECT-EATING ANIMALS

The Hedgehog, 39

The Mole, 40

An Enterprising Mole, 4r

The Use of the Mole, 4I

The Shrew, 42 


\section{ORDER IV}

FLESH-EATING ANIMALS

SUb-ORder I

\section{The FISSIPEdIA}

Animals of the Cat Kind, 43

The Lion, 44

Lion's Character, 44

Attitude towards Man, 45

The Better Part of Valour, 46

Lion's Strength, 47

"Affection, 48

“ Docility, 48

Androcles, 49

A Lion Hunt, 50

A Thrilling Experience, 52

Attacked by a Lion, 53

A Night Surprise, 55

A Lion Outwitted, $5^{6}$

Old Instincts and New Opportunities, 56

The Tiger, 57

Tigers' Ravages, $5^{8}$

An Intrepid Hunter, 60

The Leopard, 6r

Leopard's Tenacity of Life, 6I

Hunters Hunted, $6_{3}$

The Jaguar, 64

Jaguar's Strength, 65

A Night of Horror, 65

The Puma, 67

Puma's Ferocity, 67

Animals and Men, 68

The Ocelot, 69

The Clouded Tiger, 70

The Serval, 70

Common Wild Cat, 70

Domestic Cat, 7I

Cat Superstitions, $7 \mathbf{r}$

Cat as a Hunter, 72

Cat and Her Young, 72

Cat as a Foster Mother, 73

Cat as a Traveller, 74

Cat as a Sportsman, 75

Cat's Intelligence, 75

The Lynx, 76

The Chetah as Huntsman, 78

The Civits, 79

The Ichneumon, 79

Dormant Instinct, 80

The Aard Wolf, 80

The Hyæna, 80

Striped Hyæna, 82

Spotted Hyæna, 82

A Narrow Escape, 83

Animals of the Dog Kind, 84

The Wolf, 84

The Fox, 85

The Jackal, 86

Wolf's Mode of Attack, 86
Wolf's Cunning, 87

"Cowardice, 88

Hunted by Wolves, 88

A Terrible Alternative, 89

A Marvellous Escape, 89

Tame Wolves, go

The Cunning of the Fox, 90

The Fox as a Hunter, 9I

A Fox Hunt, 92

The Arctic Fox, 93

Wild Dogs, 93

The Dog, 94

Dog's Understanding; 95

"S Sense of Locality, 97

Dog Friendships and Enmities, 99

" Language, 100

Dog's Intelligence, ror

“' Mistakes, 104

Eskimo Dogs, IO4

A Hard Lot, 106

Newfoundland Dog, 107

Newfoundland's Generosity, 108

II Perception of Dan-

ger, 109

Sense of Right and

Wrong, II I

a Fidelity, $x$ I2

Newfoundland under Training, $x 12$

The Sheep Dog, Ir4

Sheep Dog's Sagacity, II5

" " Fidelity, II7

The St. Bernard, II9

St. Bernard at Work, I2r

The Greyhound, 122

Greyhound's Affection, 123

The Lurcher, 124

The Bloodhound, 125

Scent of the Bloodhound, 126

The Stag Hound, 127

A Stag Hunt, 127

The Fox Hound, ras

Fox Hound's Tenacity, 128

The Harrier, I29

The Beagle, 129

The Dalmatian Dog, I30

The Turnspit, 130

Turnspit's Sagacity, r30

The Pointer, 130

Pointer's Intelligence, $\mathbf{r}_{3} \mathbf{I}$

The Setter, r3z

Pointers and Setters, 132

Sagacity of the Setter, I33

The Spaniel, 134

Blenheim Spaniel and Cats, 135

Water Spaniel as a Witness, $x_{35}$

The Terrier, 136

The Mastiff, 136

Fidelity of the Mastiff, $1_{3} 6$

Intelligence of the Mastiff, 137

The Mastiff as Protector, 137 
The Bull Dog, I38

The Poodle, I39

The Shoe-black's Poodle, 139

Weasels, Otters, and Badgers, 140

The Polecat, I40

The Weasel, I40

Weasel and Kite, I4I

The Common Otter, I4I

The Badger, 142

The Ratel and the Skunk, 143

The Skunk, I44

The Raccoon and the Coati, 145

The Bear, 145

The Polar Bear, 146

The Black Bear, 147

Docility of the Bear, 148

The Grizzly Bear, 149

The Brown Bear, 15I

Bruin and the Honey, I5I

The Malayan Bear, I5I

\section{SUB-ORDER II}

The Pinnipedia

Sea Lions, 152

Sea Bears, 153

The Walrus, 154

The Common Seal, 155

The Seal's Docility, I56

\section{ORDER V}

WHALES AND DOLPHINS

The Right Whale, ${ }_{5} 8$

The Sperm Whale, I59

The Dolphin, I59

The White Whale, I60

The Narwhal, 160

The Porpoise, $16 r$

The Grampus, 16I

\section{ORDER VI}

The Sea Cow, I6z

\section{ORDER VII}

\section{HOOFED ANIMALS}

\section{The Horse, 162}

The Arabian Horse, 163

Affection for his Owner, 165

The Domestic Horse, 166

The Structure of a Horse, 167

The Horse's Speed, 169

The Horse's Endurance, r7o

The Horse's Memory, I7I

The Force of Habit, 172

Intelligence of the Horse, 174

Horse-Play, 176

Horses and Dogs, 177

The Ass, 78

Sagacity of the Ass, I80

Instinct of the Ass, I8I
The Trained Ass, 182

The Mule and the Hinny, 183

The Zebra, 183

The Tapir, 183

The Rhinoceros, 18 ;

Rhinoceros Hunting, I86

The Tame Rhinoceros, 187

The Hippopotamus, I88

The Haunt of the Hippopotami, 189

The Pig Family, 190

The Boar, 190

The Common Hog, 191

The Babiroussa, 192

The Peccary, Ig2

The Camel and the Dromedary, Igs

Strength and Endurance of the Camel, 193

The Camel and his Master, I94

Camel Riding, r95

A Camel's Revenge, 195

The Terrors of the Desert, 196

The Llama, Ig8

The Deer, 198

The Red Deer, rg9

A Stag Hunt, 200

The Tame Stag, 20I

The Reindeer, 201

The Moose or Elk, 204

The Fallow Deer and the Roebuck, 204

The Giraffe, 205

The History of the Giraffe, 205

Hollow-Horned Ruminants, 206

The Bull, the Bison and the Buffalo, 207

The Bull, the Ox, the Cow, 207

The Bull, 208

The Brahmin Bull, 209

The Ox, 209

The Cow, 2ro

The Pride of a Cow, aro

The Bison, 2II

Hunting the Bison, 212

The Buffalo, 213

Hunting the Indian Buffalo, 213

The Cape Buffalo, 214

Hunting the Cape Buffalo, 215

The Zebu, 216

The Yak, 216

The Antelopes, 216

The Gazelle, ar7

The Sheep and the Goat, 217

The Intelligence of the Sheep, 218

Animals and Music, 218

\section{ORDER VIII}

The Elephant, 219

The Wild Elephant, 220

Elephant Herds, 221

Elephant Friendships, 223 
Sagacity of the Elephant, 224

A Centenarian Elephant, 224

An Elephant Nurse, 225

Intelligence of the Elephant, 225

\section{ORDER IX}

The Conies, 226

\section{ORDER $\mathrm{X}$}

THE RODENTS : ANIMALS THAT

$$
\text { GNAW }
$$

Rats and Mice, 227

The Rat Family, 227

The Hamster, 228

Swarms of Rats, 228

Invaded by Rats, 229

Migrations of Rats, 230

The Intelligence of Rats, 23I

Saved by a Rat, 231

The Mouse, 232

The Harvest Mouse, 233

The Field Mouse, 233

The Dormouse, 233

The Jerboas, 234

The Beaver, 234

The European Beaver, 234

The American Beaver, 235

The Squirrel, 237

The Squirrel at Home, $23^{8}$

Tame Squirrels, 239

The Marmot, the Bobak, the Prairie Dog, 240

The Chinchilla, 240

The Porcupine, 240

The Guinea Pig, 24I

Hares and Rabbits, 24I

The Common Hare, 24I

Intelligence of the Hare, 242

A Hunted Hare, 243

Tame Hares, 244

The Common Rabbit, 245

ORDER XI

\section{TOOTHLESS ANIMALS}

The Sloth, 245

The Pazgolin, 246

The Armadillo, 246

The Cape Ant-Bear, 246

The Ant-Eater, 247

\section{ORDER XII \\ POUCHED ANIMALS}

The Opossum, 247

The Kangaroo, 247

Kangaroo Hunting, 248

\section{ORDER XIII \\ MONOTREMATA}

The Duck-billed Platypus, 249

The Australian Hedgehog, 249

\section{Class II.-Aves}

Classification, 250

\section{ORDER I}

PERCHING BIRDS

The Thrushes, 25I

The Common Thrush, 25I .

The Missel Thrush, 252

The Blackbird, 252

The Mocking Bird, 254

The Tailor Bird, 255

The Golden Crested Wren, 255

The Migration of Birds, 255

The Willow Wren, 256

The Common Wren, 256

A Wren's Music Lesson, 257

The House Wren, 257

The Nightingale, 258

Song of the Nightingale, 258

The Robin Redbreast, 259

Intelligence of the Robin, 260

The Titmouse, 260

The Golden Oriole, 26I

The Shrike, 262

The Jays, 262

The Blue Jay, 263

The Magpie, 264

Mischievous Habits of the Magpie, 264

The Raven, 266

Unnatural Parents, 267

The Tame Raven, 268

The Raven and the Dog, 269

The Rook, 270

The Carrion Crow, 270

The Jackdaw, 27r

The Chough, 271

The Bird of Paradise, 271

Hunting the Bird of Paradise, 272

The Tanagers, 273

The Tanager, 273

The Swallow, 273

Swallows in Council, a74

The House Martin, 274

The Sand Martin, 275

The Chaffinch. The Goldfinch. The

Greenfinch, 275

The Linnet, 276

The Canary, 276

The Tame Carary, 277

The Crossbill, 277

The Bunting, 277

The Starling, 278

The Common Starling, 278 
The Weaver Bird, 278

The Lark, 279

Maternal Instinct of the Lark, 280

The Lark and the Hawk, 281

The Wagtails and Pipits, 28I

The Ant-Eaters, 282

The King Bird, 282

The Chatterers, 282

The Lyre Bird, 283

\section{ORDER II}

\section{CLIMBERS AND GAPERS}

The Woodpecker, 284

The Wryneck, 284

The Cuckoo, 284

The Cuckoo and the Hedge-Sparrow, 285

The Cuckoo and the Thrush, 286

The Trogons, 287

The Kingfishers, 287

The Hornbill, 287

The Goat-Suckers, 288

The Whip-poor-Will, 288

The Chuck-Will's-Widow, 288

The Swifts, 289

The Humming Bird, 289

ORDER III

\section{THE PARROTS}

Intelligence of the Parrot, 290

Famous Parrots, 291

The Grey Parrot, 292

Parrot Talk, 293

ORDER IV

PIGEONS

Carrier Pigeons, 294

Pigeons on the Wing, 295

\section{ORDER V \\ FOWLS}

The Peacock, 297

The Pheasant, 298

The Partridge, 299

The Wild Turkey, 300

The Domestic Turkey, 300

Sagacity of the Turkey, 300

Sitting Turkey Cocks, 301

Domestic Fowls, 302

The Common Hen, 303

ORDER VI

The Hoazin, 304

ORDER VII

BIRDS OF PREY

The Eagle, 305

Eagle Shooting, 305
White-Headed Eagle, 306

The Vultures, 307

The Condor, 308

The King of the Vultures, 308

A Feast of Vultures, 309

The Secretary Bird, 3io

The Kite. The Osprey. The Buzzard, 3II

The Falcon, 3II

The Sparrow-Hawk, 312

The Owl, 313

ORDER VIII

WADING BIRDS

The Cranes, 314

The Heron, $3^{1} 4$

The Bittern, 315

The Stork, 3r5

Jealousy of the Stork, 3I5

A Stork's Revenge, $3^{16}$

\section{ORDER IX}

THE GEESE

Gratitude of the Goose, 3i 6

A Wild Goose Chase, $3^{\text {I } 7}$

Goose Friendships, 317

The Goose and the Dog, 318

Maternal Instinct of the Goose, 318

The Duck, 319

The Swan, 3rg

Maternal Instinct of the Swan, 320

Intelligence of the Swan, 320

The Swan and the Fawn, 321

The Common Sea-Gull, $3^{21}$

A Tame Sea-Gull, 321

Mother Carey's Chicken, 322

Carching the Stormy Petrel, $3^{\text {en }}$

The Cormorant, 323

The Albatross, 324

The Pelican, 325

A Tame Pelican, 325

The Penguin, 326

The Puffin, 327

ORDER $X$

THE OSTRICHES

The Ostrich and its Young, 321

The Rhea. The Cassowary. The Emu, 329

\section{Vertebrata}

\section{Class III.-Reptilia}

ORDER I

The Tortoise and the Turtle, 331

The Elephant Tortoise, 332

The Turtle, 333 
ORDER II

The Crocodile, 334:

The Alligator, 335

A Tame Alligator, 336

ORDER III

Hatteria Punctata, 337

ORDER IV

The Lizards, 337

The Chameleon, 337

The Iguana, 338

The Common Lizard, 338

The Monitor, 339

Snakes, 339

\section{ORDER V}

The Viper, 340

The Viper and its Young, 340

The Rattlesnake, 34I

The Sting of the Rattlesnake, 34I

The Black Snake and the Rattlesnake, $342^{\prime}$

The Cobra, 342

Snake Charming, 343

The Cobra as Companion of the Bath, 344

A Night with a Cobra, 345

An Unpleasant Bedfellow, 345

The Boa Constrictor, 346

The Boa and its Prey, 346

The Boa's Appetite, 347

A Terrible Boa, 348

A Narrow Escape, 348
Vertebrata

Olass IV.-Batrachla

The Batrachia, 350

The Common Toad, 351

Tame Toads, 351

The Common Frog, 352

Ingenuity of the Frog, 352

The Tree Frog, 353

\section{Vertebrata \\ Class V,-Pinces}

Fishes, 354

The Sticklebacks, 354

The Stickleback and the Leech, 355

The Mackerel, 356

The Sword Fish, 356

The Cod, 357

The Salmon, $35^{8}$

The Pike, $35^{8}$

The Herring, 360

The Flying Fish, 360

The Eel, 36r

The Gymnotus, 362

Catching the Gymnotus, 362

The Torpedo, 365

The Shark, 366

The White Shark, 366

Sharks in the South Seas, $\mathbf{3}^{67}$

The Rays, 368

Ray Catching, 369 


\title{
NATURAL HISTORY IN ANECDOTE.
}

\author{
INTRODUCTION.
}

Boienoe. Science is classified truth. Men study the heavenly bodies, note their characteristics, observe their movements, and define their relationships; and having verified their deductions by repeated experiments, arrange the truths they have discovered into systems, and by classifying their knowledge reduce it to a science: this science they call Astronomy. Astronomy is thus the classified arrangement of all known truths concerning the heavenly bodies. Geology, similarly, is the classified arrangement of all known truths concerning the material structure of the Earth.

The Kingdoms The Natural World has been variously divided of Nature. for the purposes of study. Linnæus divided it into three kingdoms; (I) the Mineral kingdom (II) the Vegetable kingdom and (III) the Animal kingdom, thus naming the three kingdoms in the order of their natural geneses. The Mineral kingdom comprises the inorganic forms of nature,-those which have no organism and which can only increase by external addition. The Vegetable and Animal kingdoms comprise the organic life of nature,-those forms which are provided with means for promoting their own development and propagating species. The Vegetable kingdom, while easily distinguishable from the Mineral kingdom is in some of its forms so similar to the lower forms of animal life as to suggest relationship between the two; while the Animal lkingdom, beginning with the lower forms which approximate so closely to vegetable forms, 
embraces the whole range of animal life and reaches its highest order in man. The science which treats of organic life as a whole is called Biology, while its two departments are separately known as Botany and Zoology. Natural History is a general term popularly applied to the study of Zoology.

Zoology. Zoology is the science of animal life. It deals with the origin of species, and the evolution of the varied forms of animated nature, and treats of the structure, habits, and environment of all living creatures. Scientifically speaking, Zoology is the classified arrangement of all known truths concerning all animal organisms.

Classification. For convenience in study the Animal kingdom is divided into seven Sub-kingdoms, each of which is further divided into classes. These Sub-kingdoms are known as: I Vertebrata, II Arthropoda, III Mollusca, IV Echinodermata, V Vermes, VI Colenterata, and VII Protozoa. Sub-kingdom I, Vertebrata, includes all animals distinguished by the possession of Vertebræ or back-bones, and its classes are I Mammalia:animals that suckle their young; II Aves:-Birds; III Reptilia:-Reptiles; IV Batrachia:-Frogs, Toads, etc.; and V Pisces:-Fishes. Sub-kingdom II, Arthropoda, includes the Insect families, etc., which it also divides into classes. Sub-kingdom III, Mollusca, animals of the cuttle-fish order, including limpets, oysters, and slugs. Sub-kingdom IV, Echinodermata, a large number of marine animals, such as the star-fish and the sea-urchin. Sub-kingdom V, Vermes, the various classes of worms. Sub-kingdom VI, Cœlenterata, corals and sponges, etc., etc., and Sub-kingdom VII, Protozoa, protoplasms and the lowest forms of animal life. This volume is devoted to the illustration of the first of these sub-kingdoms, the Vertebrata, with its five classes, Mammalia, Aves, Reptilia, Batrachia and Pisces. 


\section{THE ANIMAL KINGDOM.}

\section{SUB-KINGDOM I-VERTEBRATA.}

\section{CLASS I-MAMMALIA.}

ORDER I. The most perfect of all animals is man, for PRIMATES. besides having a marvellous animal organism he possesses reason, which so far transcends the highest instincts of other animals, that it places him in a category by himself.

SUB ORDER I. Next to man it is convenient to deal Man-shaped with man-shaped animals, (anthropoidea)Animals. those animals which most resemble him in external appearance and internal organism. This brings us to the order called Quadrumana or four-handed animals which include Lemurs and their allied forms, and manlike monkeys. Monkeys are divided into five families, one at least of which has to be further divided into sub-families to accommodate its variety. These families are: I The Apes; II The Sacred Monkeys; III The Cheek-pouched Monkeys; IV The Cebidae, with its several sub-families, and V The Marmosets. The first three of these families inhabit the old world, the last two belong to the new.

The Ape The family of the Apes includes the Gorilla,

Family. the Chimpanzee, the Orang-utan or mias, the Gibbons or long-armed Apes, and the Siamang; of these the Gorilla and the Chimpanzee belong to the West of Africa, the Orang-utan to Borneo, the Gibbons to Assam, the Malay 
Peninsula, Java, Sumatra, Borneo, Cambodia and Hainan, and the Siamang to Java and Sumatra.

The Gorilla. The gorilla is the largest of the ape family, and sometimes attains to the height of six feet. It is also the fiercest, if not the strongest, of man-shaped animals. It belongs to the genus Troglodytes of which the chimpanzee is the only other species, and it inhabits a somewhat limited range of Equatorial Africa, where it makes for itself nests of sticks and foliage, among the lower branches of trees, and lives upon berries, nuts and fruits. Though apparently a vegetarian the gorilla has enormous physical strength. His arms bear much the same proportion to the size of his body as those of man do relatively, but his lower limbs are shorter, and have no calves, the leg growing thicker from the knee downwards. The hands are broad, thick, and of great length of palm, and are remarkable for their strength; the feet, broader than those of man, and more like hands, are very large and of great power. The gorilla uses his hands when walking or running, but as his arms are longer than those of other apes, and his legs shorter he stoops less than they do in moving from place to place. The gorilla herds in small companies, or rather families, one adult male being the husband and father of the band. The females are much smaller than the males.

The Ancestors The gorilla, though rediscovered in recent of the years, was apparently known to the ancients. Gorills. Hanno, a Carthaginian admiral who flourished some five or six hundred years B.C., once sailed from Carthage with a fleet of sixty vessels and a company of 30,000 persons, under instructions to proceed past the Pillars of Hercules (the Straits of Gibraltar), with a view to planting colonies on the western coast of Africa. In the course of their travels they discovered several islands inhabited by wild creatures with hairy bodies. "There were," says the ancient navigator, "many more females than males, all equally 
covered with hair on all parts of the body. The interpreters called them gorillas. On pursuing them, we could not succeed in taking a single male, they all escaped with astonishing swiftness, and threw stones at us; but we took three females, who defended themselves with so much violence, that we were obliged to kill them; but we brought their skins, stuffed with straw, to Carthage." Professor Owen remarks upon this that "though such creatures would suggest to Hanno and his crew no other idea of their nature than that of a kind of human being, yet the climbing faculty, the hairy body, and the skinning of the dead specimens strongly suggest that they were great apes. The fact that apes somewhat resembling the negroes, of human size and with hairy bodies, still exist on the west coast of Africa renders it highly probable that such were the creatures which Hanno saw, captured, and called 'gorullai'."

A Gorilla Hunt. Paul du Chaillu, in his "Stories of the Gorilla Country, " gives a graphic description of his first sight of these "wild men of the woods." He was inspecting the ruins of a native village with a party of Africans, when they discovered footprints which the natives immediately recognised as those of the gorilla. "It was," says he, "the first time I had seen the footprints of these wild men of the woods, and I cannot tell you how I felt. Here was I now, it seemed, on the point of meeting, face to face, that monster, of whose ferocity, strength and cunning, the natives had told me so much, and which no man before had hunted. By the tracks it was easy to know that there must have been several gorillas in company. We prepared at once to follow them. My men were remarkably silent, for they were going on an expedition of more than usual risk; for the male gorilla is literally the king of the forest-the king of the equatorial regions. $\mathrm{He}$ and the crested lion of Mount Atlas are the two fiercest and strongest beasts of that continent. The lion of South Africa cannot be compared with either 
for strength or courage. As we left the camp, the men and women left behind crowded together, with fear written on their faces. Miengai, Ngolai, and Makinda set out for the hunt in one party; myself and Yeava formed another. We determined to keep near each other, so that in case of trouble we might be at hand to help one another. For the rest silence and a sure aim were the only cautions to be given. I confess that $I$ was never more excited in my life. For years I had heard of the terrible roar of the gorilla, of its vast strength, of its fierce courage when only wounded. I knew that we were about to pit ourselves against an animal which even the enormous leopards of the mountains fear, which the elephants let alone and which perhaps has driven away the lion out of his territory; for the king of beasts, so numerous elsewhere in Africa, is not met with in the land of the gorilla. We descended a hill, crossed a stream on a fallen log, crept under the trees, and presently approached some huge boulders of granite. In the stream we had crossed we could see plainly that the animals had just crossed it, for the water was still disturbed. Along side of the granite blocks lay an immense dead tree, and about this the gorillas were likely to be: Our approach was very cautious. With guns cocked and ready we advanced through the dense wood, which cast a gloom even at mid-day over the whole scene. I looked at my men and saw that they were even more excited than myself. Slowly we pressed on through the dense bush, dreading almost to breathe for fear of alarming the beasts. Makinda was to go to the right of the rock, while I took the left. Unfortunately he and his party circled it at too great a distance. The watchful animals saw him. Suddenly I was startled by a strange, discordant, half human cry, and beheld four young and half-grown gorillas running towards the deep forest. I was not ready. We fired but hit nothing. Then we rushed on in pursuit; but they knew the woods better than we. Once I caught 
a glimpse of one of the animals again; but an intervening tree spoiled my mark, and I did not fire. We pursued them till we were exhausted, but in vain. I protest I felt almost like a murderer when I saw the gorilla this first time. As they ran on their hind legs with their heads down, their bodies inclined forward, their whole appearance was that of hairy men running for their lives. Add to this their cry, so awful yet with something human in its discordance, and you will cease to wonder that the natives have the wildest superstitions about these 'wild men of the woods.'"

Du Chaillu's In his "Explorations and Adventures in EquaFirst Gorilla torial Africa" du Chaillu gives an equally thrilling account of the capture of his first gorilla. He says : "We started early, and pushed through the most dense and impenetrable part of the forest; in hopes to find the very home of the beast I so much wished to shoot. Hour after hour we travelled and yet no signs of gorillas. Only the everlasting, little, chattering monkeys-and not many of these-and occasionally birds. Suddenly Miengai uttered a little cluck with his tongue which is the native way of showing that something is stirring and that a sharp lookout is necessary. And presently I noticed, ahead of us seemingly, a noise as of some one breaking down branches or twigs of trees. This was a gorilla-I knew at once by the eager satisfied looks of the men. We walked with the greatest care making no noise at all. Suddenly, as we were yet creeping along, in a silence which made a heavy breath seem loud and distinct, the woods were at once filled with the tremendous barking roar of the gorilla. Then the underbrush swayed rapidly just ahead, and presently before us stood an immense male gorilla. He had gone through the jungle on all fours; but when he saw our party he erected himself and looked us boldly in the face. $\mathrm{He}$ stood about a dozen yards from us, and was a sight I think I shall never forget. Nearly six feet high (he proved 
four inches shorter), with immense body, huge chest, and great muscular arms, with fiercely glaring, large, deep gray eyes, and a hellish expression of face, which seemed to me like some nightmare vision: thus stood before us this king of the African forest. $\mathrm{He}$ was not afraid of us. $\mathrm{He}$ stood there and beat his breast with his huge fists till it resounded like an immense bass-drum, which is the gorillas' mode of offering defiance; meantime giving vent to roar after roar. The roar of the gorilla is the most singular and awful noise heard in these African woods. It begins with a sharp bark, like an angry dog, then glides into a deep bass roll, which literally and closely resembles the roll of distant thunder along the sky. So deep is it that it seems to proceed less from the mouth and throat than from the deep chest and vast paunch. His eyes began to flash fiercer fire as we stood motionless on the defensive, and the crest of short hair which stands on his forehead began to twitch rapidly up and down, while his powerful fangs were shown as he again sent forth his thunderous roar. He advanced a few steps-then stopped to utter that hideous roar againadvanced again, and finally stopped when at a distance of about six yards from us. And here, just as he began another of his roars, beating his breast with rage, we fired, and killed him. With a groan which had something terribly human in it, and yet was full of brutishness, he fell forward on his face. The body shook convulsively for a few minutes, the limbs moved about in a struggling way, and then all was quiet: death had done its work, and I had leisure to examine the huge body. It proved to be five feet eight inches high, and the muscular development of the arms and breast showed what immense strength it had possessed." A smaller gorilla, shot by M. du Chaillu on another occasion, measured five feet six inches in height, fifty inches round the chest, and his arms had a spread of seven feet two inches. 

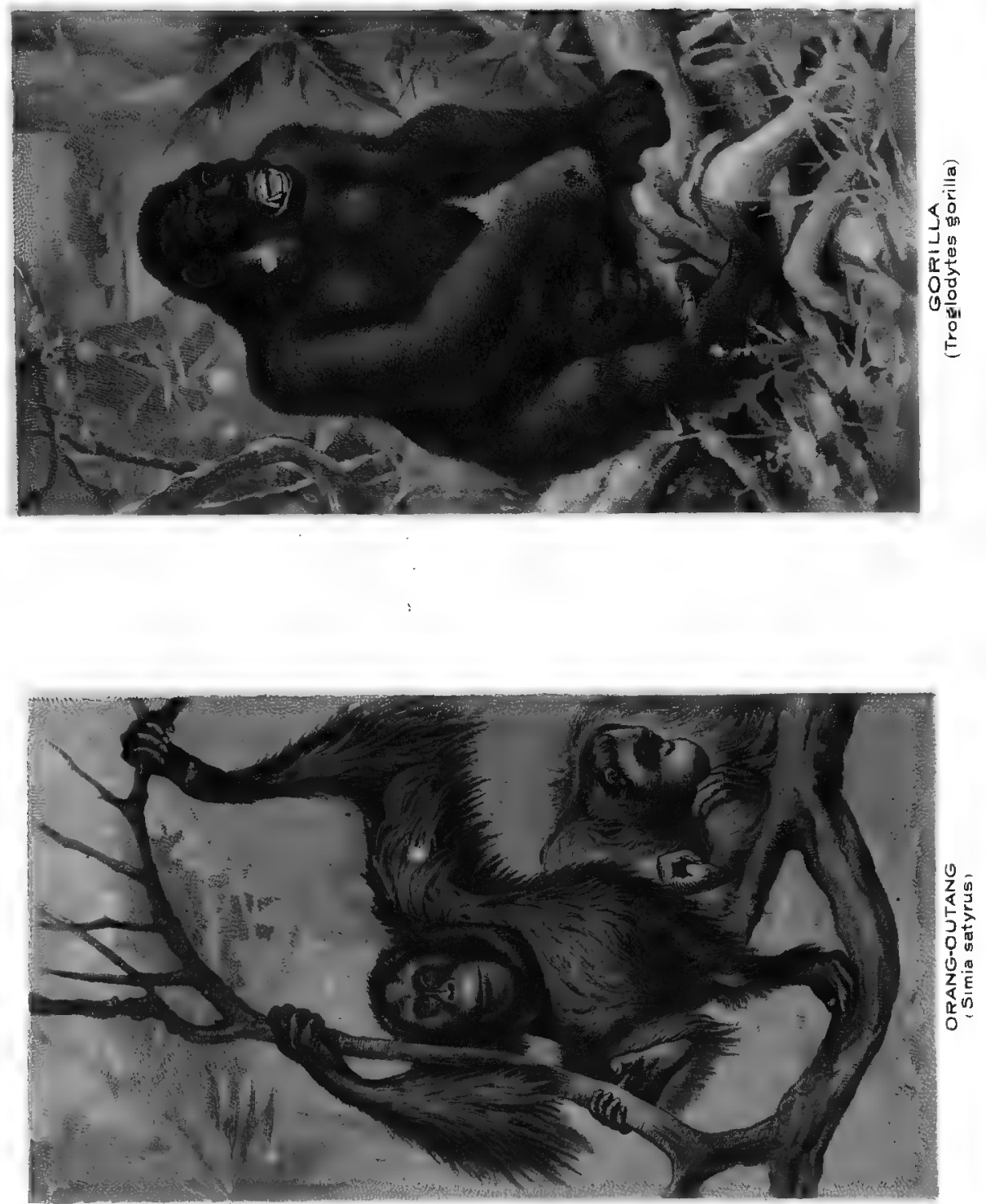

Digitized by Microsoft $₫$ 
Digitized by Microsofte 
^ Young A young gorilla which some natives succeeded Gorilla. in capturing for M. du Chaillu, and which he named "Fighting Joe," forms the subject of one of his most interesting chapters. The young cub was caught by the adroit use of a cloth which one of the natives managed to throw over his head, but not until he had severely bitten one of his captors in the hand and taken a mouthful out of the leg of another. $\mathrm{He}$ was about three years old, three feet six inches in height and of great strength. A cage was made for him, from which he twice escaped, on each occasion being recaptured by the use of fishing nets. On his first escape he concealed himself under the bed in M. du Chaillu's house. "Running in," says the writer, "to get one of my guns, I was startled by an angry growl. It was master Joe; there was no mistake about it; I knew his growl too well. I cleared out faster than I came in. I instantly shut the windows and called in my people to guard the door. When Joe saw the crowd of black faces he became furious, and with his eyes glaring, and every sign of rage in his face and body, he got out from beneath the bed. He was about to make a rush at all of us. He was not afraid. A stampede of my men took place, I shut the door quickly (from outside) and left Joe master of the premises." While the men outside were devising means for his recapture, the young gorilla carefully inspected the furniture and M. du Chaillu became apprehensive for the safety of his clock, the ticking of which was likely to attract unwelcome attention. However, by means of a net dexterously thrown over him, he was secured once more and carried back to his cage, which in the meantime had been repaired, the full strength of four men being required for the purpose. On his second escape he made for the woods and took refuge in a large clump of trees. "This we surrounded," says M. du Chaillu. "He did not ascend a tree, but stood defiantly at the border of the wood. About one hundred and fifty of us surrounded 
him. As we moved up he began to yell, and made a dash upon a poor fellow who was in advance. The fellow ran and tumbled down in affright. By his fall he escaped the tender mercies of Joe's teeth; but he also detained the little rascal long enough for the nets to be thrown over him." But Joe was a child of nature and could not live with the chain of civilisation around his neck, and he died somewhat suddenly some ten days afterwards and finally found his way to the British museum.

Gorilla According to du Chaillu, the natives entertain Superstitions. many superstitions about the gorilla, among the commonest of which is the belief that some gorillas are inhabited by human spirits. In his "Stories of the Gorilla Country" he gives an interesting illustration of this. "In the evening," he says, "the men told stories about gorillas. 'I remember," said one, 'my father told me he once went out to the forest, when just in his path he met a great gorilla. My father had his spear in his hand. When the gorilla saw the spear he began to roar; then my father was terrified and dropped the spear. When the gorilla saw that my father had dropped the spear he was pleased. He looked at him, and then left him and went into the thick forest. Then my father was glad and went on his way.' Here all shouted: 'Yes! so we must do when we meet the gorilla. Drop the spear; that appeases him.' Next Gambo spoke. 'Several dry seasons ago, a man suddenly disappeared from my village after an angry quarrel. Some time after an Ashira of that village was out in the forest. He met a very large gorilla. That gorilla was the man who had disappeared; he had turned into a gorilla. He jumped upon the poor Ashira and bit a piece out of his arm; then he let him go. Then the man came back with the bleeding arm. He told me this, I hope we shall not meet such gorillas.' Chorus: 'No; we shall not meet such wicked gorillas.' "I myself," says du Chaillu, "afterwards met that man in the Ashira 
country. I saw his maimed arm and he repeated the same story." Then one of the men spoke up: "If we kill a gorilla to-morrow, I should like to have a part of the brain for a fetich. Nothing makes a man so brave as to have a fetich of gorilla's brain. That gives a man a strong heart." Chorus (of those who remained awake) 'Yes; that gives a man a strong heart.'" A fetich of the brain of the gorilla is said also to help its owner in love as well as war.

The Chimpanzee. The chimpanzee is a near neighbour of the gorilla in Equatorial Africa though he appears to have a more extended range. $\mathrm{He}$ is found in Sierra Leone and in the country lying to the north of the river Congo, and according to native accounts is gregarious in his habits, travelling in formidable companies, who carry sticks and make effective use of them. They are said to reach maturity at nine or ten years of age and to attain a height of from four to five feet. Like the gorillas they have immensely powerful limbs, and have been known without apparent effort to break off branches of trees which a man would have been powerless to bend.

The Docility The chimpanzee differs from the gorilla in and Sagacity his amenability to civilisation. The gorilla,
of the Chimpanzee. however young, seems incapable of being tamed; while the chimpanzee in its infancy and youth at least has often been domesticated, though like most other apes, as it approaches maturity, it needs to be kept under strong control. Captain Brown in his "Habits and Characteristics of Animals and Birds" gives the following illustration of the docility and sagacity of the chimpanzee. He says: "M. de Grandpré saw, on board of a vessel, a female chimpanzee, which exhibited wonderful proofs of intelligence. She had learnt to heat the oven; she took great care not to let any of the coals fall out, which might have done mischief in the ship; and she was very accurate in observing when the oven was heated to the proper degree, of which she immediately 
apprized the baker, who, relying with perfect confidence upon her information, carried his dough to the oven as soon as the chimpanzee came to fetch him. This animal performed all the business of a sailor, spliced ropes, handled the sails, and assisted at unfurling them; and she was, in fact considered by the sailors as one of themselves. The vessel was bound for America; but the poor animal did not live to see that country, having fallen a victim to the brutality of the first mate, who inflicted very cruel chastisement upon her, which she had not deserved. She endured it with the greatest patience, only holding out her hands in a suppliant attitude, in order to break the force of the blows she received. But from that moment she steadily refused to take any food, and died on the fifth day from grief and hunger. She was lamented by every person on board, not insensible to the feelings of humanity, who knew the circumstances of her fate."

The The orang-utan is one of the largest of the Orang-utan. ape species and until the discovery of the gorilla was supposed to be the largest. It is said sometimes to attain to the height of six feet, and some travellers' tales credit it with even greater height. The orang is possessed of great strength but is of a docile disposition when brought under civilisation, and even in a wild state is often quiet and peaceable except when attacked. It inhabits country that is low, level, and swampy, and that is at the same time covered with lofty virgin forests. It belongs to the genus Simia of which it is the single species.

The Habits The following account of the orang is given of the by Mr. Brooke of Sarawak. "On the habits of Orang-utan. the orangs, as far as I have been able to observe them, I may remark that they are as dull and as slothful as can well be conceived, and on no occasion, when pursuing them, did they move so fast as to preclude my keeping pace with them easily through a moderately clear 
forest; and even when obstructions below (such as wading up to the neck) allowed them to get away some distance, they were sure to stop and allow us to come up. I never observed the slightest attempt at defence; and the wood, which sometimes rattled about our ears, was broken by their weight, and not thrown, as some persons represent. If pushed to extremity, however, the pappan could not be otherwise than formidable; and one unfortunate man, who with a party was trying to catch one alive, lost two of his fingers, besides being severely bitten on the face, whilst the animal finally beat off his pursuers and escaped. When hunters wish to catch an adult, they cut down a circle of trees round the one on which he is seated, and then fell that also, and close before he can recover himself, and endeavour to bind him. The rude hut which they are stated to build in the trees would be more properly called a seat, or nest, for it has no roof or cover of any sort. The facility with which they form this seat is curious; and I had an opportunity of seeing a wounded female weave the branches together, and seat herself in a minute. She afterwards received our fire without moving, and expired in her lofty abode, whence it cost us much trouble to dislodge her. The adult male I killed was seated lazily on a tree; and when approached only took the trouble to interpose the trunk between us, peeping at me and dodging as I dodged. I hit him on the wrist, and he was afterwards despatched." The Walk In locomotion the orang disdains the earth of the and perambulates the vernal terraces of the Orang-utan. forest trees. "It is a singular sight," says $\mathrm{Mr}$. Wallace, "to watch a mias (orang-utan) making his way leisurely through a forest. He walks deliberately along some of the larger branches in the semi-erect attitude which the great length of his arms and the shortness of his legs cause him naturally to assume, and seems always to choose those branches which intermingle with an adjoining tree, on 
approaching which he stretches out his long arms, and seizing the opposing boughs, grasps them together with both hands, seems to try their strength, and then deliberately swings himself across to the next branch on which he walks along as before. He never jumps or springs, or even appears to hurry himself, and yet manages to get along almost as quickly as a person can run through the forest beneath."

The Strength "The Dyaks," says Mr. Wallace, "all declare of the that the mias is never attacked by any animal in Orang-utan. the forest, with two rare exceptions; and the accounts received of these are so curious that $I$ give them nearly in the words of my informants, old Dyak Chiefs, who had lived all their lives in the places where the animal is most abundant. The first of whom I enquired said, 'No animal is strong enough to hurt the mias, and the only creature he ever fights with is the crocodile. When there is no fruit in the jungle he goes to seek food on the banks of the river where there are plenty of young shoots that he likes, and fruits that grow close to the water. Then the crocodile sometimes tries to seize him, but the mias gets upon him and beats him with his hands and feet, and tears and kills him.' He added that he had once seen such a fight and that he believed that the mias is always the victor. My next informant was Orang Kayo or chief of the Balow Dyaks on the Simunjou River. He said the mias has no enemies, no animals dare attack it but the crocodile and the python. He always kills the crocodile by main strength, standing upon it, and pulling open its jaws and ripping up its throat. If a python attacks a mias he seizes it with his hands and then bites it, and soon kills it. The mias is very strong; there is no animal in the jungle so strong as he."

The Docility Buffon thus describes an orang-utan that he of the saw: "His aspect was melancholy, his deOrang-utan. portment grave, his movements regular, and 
his disposition gentle. Unlike the baboon or the monkey, who are fond of mischief, and only obedient through fear, a look kept him in awe; while the other animals could not be brought to obey without blows. He would present his hand to conduct the people who came to visit him, and walk as gravely along with them as if he had formed a part of the company. I have seen him sit down at table, when he would unfold his towel, wipe his lips, use a spoon or a fork to carry his victuals to his mouth, pour his liquor into a glass, and make it touch that of a person who drank along with him. When invited to take tea, he would bring a cup and saucer, place them on the table, put in sugar, pour out the tea, and allow it to cool before he drank it. All this I have seen him perform without any other instigation than the signs or the command of his master, and often even of his own accord." The Orang-utan's M. de la Bosse thus describes two young Intelligence. orang-utans, male and female. "We had these animals with us on shipboard. They ate at the same table with us. When they wanted anything, they, by certain signs, acquainted the cabin boy with their wishes; and if he did not bring it, they sometimes flew into a rage at him, bit him in the arm, and not unfrequently threw him down. The male fell sick during the voyage, and submitted to be treated like a human patient. The disease being of an inflammatory nature, the surgeon bled him twice in the right arm; and when he afterwards felt himself indisposed, he used to hold out his arm to be bled, because he recollected that he found himself benefited by that operation on a former occasion."

The Orang-utan's Dr. Tyson in describing one of the earliest

Affection. specimens of the orang brought to London, says that it conceived a great affection for those with whom travel had made it familiar, frequently embracing them with the greatest tenderness. A female orang belonging to a Dutch menagerie showed the greatest affection for her attendants, 
giving unmistakable signs of her delight in their company and distress in their absence. She would often take the hay from her bed and spread it at her side and with anxious and obvious signs invite her keeper to sit beside her. M. Palavicini credited a pair of orangs which he had in his possession in 1759 with the still more remarkable quality in animals of bashfulness. It is said that the female would shrink from the too persistent gaze of a spectator, and throw herself into the arms of the male, hiding her face in his bosom.

The Maternal In his "Marvels and Mysteries of Instinct,"

Instinct. Mr. Garrett gives the following instance of maternal affection. "A gentleman was out with a party of men in Sumatra, when in some trees removed from a dense forest a female orang-utan, with a young one in its arms, was discovered, and the pursuit commenced. In the ardour of the moment, and excited by the hope of possessing an animal so rare, the gentleman forgot everything but the prize before him, and urged on his men by the promise of a reward, should their exertions be successful. Thus stimulated they followed up the chase; the animal, encumbered by her young one, making prodigious efforts to gain the dense and intricate recesses of the wood, springing from tree to tree, and endeavouring by every means to elude her pursuers. Several shots were fired, and at length one took fatal effect, the ball penetrating the right side of the chest. Feeling herself mortally wounded, and with the blood gushing from her mouth, she from that moment took no care of herself, but with a mother's feelings summoned up all her dying energies to save her young one. She threw it onwards over the tops of the trees, and from one branch to another, taking the most desperate leaps after it herself, and again facilitating its progress until, the intricacy of the forest being nearly gained, its chances of success were sure. All this time the blood was flowing: but her efforts had been unabated, 
and it was only when her young one was on the point of attaining to a place of safety that she rested on one of the topmost branches of a gigantic tree. True to her ruling passion, even in death, she turned for a moment to gaze after her young one, reeled, and fell head foremost to the ground. The sight was so touching that it called forth the sympathy of the whole party. The eagerness of the chase subsided; and so deep an impression did the maternal tenderness and unexpected self-devotion of the poor orang make on the gentleman alluded to, whose heart was indeed formed in 'nature's gentlest mould,' that he expressed the utmost remorse and pity, declaring that he would not go through the same scene again for all the world; nor did the tragical death of the animal cease to haunt his mind for many weeks, and he never afterwards recurred to it but with feelings of emotion. The preserved skin is now in the Museum of the Zoological Society."

Gibbons or Long The gibbons belong to the genus Hylobates, Armed Apes. of which there are several species. They are characterised by the ability to walk almost erect, hence the name Hylobates. They live in the tops of trees, in large companies and possess marvellous powers of locomotion, swinging themselves from tree to tree with such rapidity as to bafle all pursuit. When on the ground they balance themselves in walking by holding their hands above their heads. The adult gibbon is about three feet in height and has a reach of arms of about six feet. The gibbon is tractable and capable of strong affection towards those who show it kindness. One of the Hoolock species petted by Dr. Burrough, became companionable and would sit at his master's breakfast-table, eat eggs and chicken, and drink tea and coffee with great propriety. Fruit was his favourite food, but insects were especially palatable to him and he was an expert in catching flies. The siamang differs from the other species of long-armed apes in the formation of its 
feet and in several other characteristics. It is, however, similar to the Hoolock in its amenity to kindness and its affection for its master, when brought under the influence of kindly treatment. The gibbons have great strength in their lower limbs, whereby they are enabled to leap surprising distances. M. Duvaneel said he once saw one of these animals clear a space of forty feet, from the branch of a tree. Mr. George Bennet, in his "Wanderings," describes the action of a siamang that belonged to him, which having managed to free himself of his tether, proceeded to embrace the legs of the Malays whom he came across, until he discovered his former master, whereupon he climbed into the Malay's arms and hugged him with the tenderest affection.

Monkeys. Monkeys differ from the apes we have dealt with in the important characteristic, among others, of possessing tails. These vary in length from inches to feet, in some cases being considerably longer than the body and in others little more than stumps. They vary also in form, some being completely covered with hair, and others only partially so; some apparently useful only as ornaments, others being prehensile, that is capable of grasp, and giving their owners almost the advantage of a fifth limb.

The Sacred The Sacred Monkeys (Semnopithecida) inMonkeys. clude two genera and a large number of species. Among these are the species which bear the name of Hanumán, a Hindoo divinity, and are worshipped in his honour. The protection these monkeys receive on account of the superstitions prevalent concerning them, leads to their large increase in numbers and to many inconveniences arising therefrom. It is said that if a traveller should be unfortunate enough to offend one of these animals he is likely enough to be followed by the whole party howling in a most hideous and discordant manner, and pelting him with any missiles upon which they can lay their hands. There are eighteen species of the Semnopithecus, all of which 
are found in the East. Of these the Entellus is one of the best known species. It is very susceptible to cold, and cannot live long in Europe.

The Long-nosed The Long-nosed Monkey (Semnopithecus

Monkey. Larvatus) belongs to this family and is distinguished, as its name implies, by the length of its proboscis. This animal is described by Wallace as about the size of a child of three years of age, while possessing a nose considerably longer than that of any human adult. From the head to the tip of the tail the proboscis monkey measures about four feet and a half. It is sometimes called the Kahau from its cry which resembles the sound of that word. It is said to hold its nose when leaping to protect it from being injured by the branches of trees. The second genus of this family, of which there are numerous species, belongs to Africa.

Cheek-pouched The Cheek-pouched Monkeys form the Monkeys. third family of the quadrumana. They include seven genera, and sixty or seventy species, of which five genera belong to Africa and two to Asia and to the Malay Islands. Among the better known of these species is the Talapoin of West Africa; the Diana monkey and the Mona (Africa); the little White-nosed monkey (Guinea); the Grivet (Nubia and Abyssinia); the Green monkey (Cape de Verds); the Patas (Senegal); the Malbrouck monkey; and the Vervet monkey (South Africa). The Green monkey and the Vervet monkey are those most commonly seen in England. One of the best known members of this family is the Baboon.

The Baboon. The baboon is found in many parts of Africa, and one of its species in Arabia. It is of the genus cynocephalus, and some of its species attain to considerable size; the head and face of one species resembling those of a dog, it is sometimes called the dog-faced baboon. The baboon herds in large numbers, and is said to make apparently organized attacks upon villages during the 
absence of the peasants in harvest time, placing sentinels on the look out, to apprise them of danger, while they visit the houses and take possession of all the food they can find. They are cunning and powerful, and formidable in combat, but, greedy in habit, they eat to excess, and when gorged to satiety fall an easy prey to their enemies. In their wild state they feed on berries and bulbous roots, but when proximity to civilisation gives them wider opportunity, they show their appreciation of a more varied menu. Among the more familiar species of the baboon are the Chackma, the Drill, the Mandrill, the Anubis, the Babouin, and the Sphinx, all of which belong to the West of Africa.

The

The Arabian baboon is an animal with a Arabian history. It was worshipped by the Egyptians,

Baboon. who embalmed its body after death and set apart portions of their cemeteries for its use. Sacred to Thoth, the Egyptian Hermes, the God of letters, the baboon sometimes represents that deity in Egyptian sculptures, where it is usually figured in a sitting posture, the attitude in which its body was generally embalmed. The baboon was also held as emblematic of the Moon, and honoured symbolically in other connections. It is commonly represented in judgment scenes of the dead with a pair of scales in front of it, Thoth being supposed to exercise important duties in the final judgment of men. The baboon was held especially sacred at Hermopolis. According to Sir J. G. Wilkinson the Egyptians trained baboons to useful offices, making them torch-bearers at their feasts and festivals.

The

Like others of the monkey tribes the baboon

Imitative

Fieulty

of the shows an extraordinary faculty for imitation. Captain Browne in his "Characteristics of Ani-

Baboon. mals" says: "The following circumstance is truly characteristic of the imitative powers of the baboon:The army of Alexander the Great marched in complete battlearray into a country inhabited by great numbers of baboons, 
and encamped there for the night. The next morning, when the army was about to proceed on its march, the soldiers saw, at some distance, an enormous number of baboons, drawn up in rank and file, like a small army, with such regularity, that the Macedonians, who could have no idea of such a manœuvre, imagined at first that it was the enemy drawn up to receive them."

The

The chackma lives among the mountains of Chackma the Cape of Good Hope, where he attains about

Baboon. the size of an English mastiff and even greater strength. He descends to the plains on foraging expeditions, and, when not attacked, will usually make off on the approach of danger, but if aroused to anger can both show and use his teeth, and is far superior to the average English boy in throwing stones.

The Baboon's Le Vaillant gives an interesting account of

Utility. a chackma baboon which accompanied him through South Africa, and which bore the name of Kees. He says: "I made him my taster. Whenever we found fruits or roots, with which my Hottentots were unacquainted, we did not touch them till Kees had tasted them. If he threw them away, we concluded that they were either of a disagreeable flavour, or of a pernicious quality, and left them untasted. The monkey possesses a peculiar property, wherein he differs greatly from other animals, and resembles man,namely, that he is by nature equally gluttonous and inquisitive. Without necessity, and without appetite, he tastes every thing that falls in his way, or that is given to him. But Kees had a still more valuable quality,--he was an excellent sentinel; for, whether by day or night, he immediately sprang up on the slightest appearance of danger. By his cry, and the symptoms of fear which he exhibited, we were always apprized of the approach of an enemy, even though the dogs perceived nothing of it. The latter, at length, learned to rely upon him with such confidence, that they slept on in per- 
fect tranquillity. I often took Kees with me when I went hunting; and when he saw me preparing for sport, he exhibited the most lively demonstrations of joy. On the way, he would climb into the trees to look for gum, of which he was very fond. Sometimes he discovered to me honey, deposited in the clefts of rocks, or hollow trees. But, if he happened to have met with neither honey nor gum, and his appetite had become sharp by his running about, I always witnessed a very ludicrous scene. In those cases, he looked for roots, which he ate with great greediness, especially a particular kind, which, to his cost, I also found to be very well tasted and refreshing, and therefore insisted upon sharing with him. In order to draw these roots out of the ground, he employed a very ingenious method, which afforded me much amusement. He laid hold of the herbage with his teeth, stemmed his fore feet against the ground, and drew back his head, which gradually pulled out the root. But if this expedient, for which he employed his whole strength, did not succeed, he laid hold of the leaves as before, as close to the ground as possible, and then threw himself heels over head, which gave such a concussion to the root, that it never failed to come out.

The Tame "Serpents excepted, there were no animals of

Baboon. whom Kees stood in such great dread as of his own species,-perhaps owing to a consciousness of loss of natural capacity. Sometimes he heard the cry of other apes among the mountains, and, terrified as he was, he yet answered them. But, if they approached nearer, and he saw any of them, he fled, with a hideous cry, crept between our legs, and trembled over his whole body. It was very difficult to compose him, and it required some time before he recovered from his fright.

The Cunning "Like all other animals, Kees was addicted to of the stealing. $\mathrm{He}$ understood admirably well how Baboon. to loose the strings of a basket, in order to take 
victuals out of it, especially milk, of which he was very fond. My people chastised him for these thefts; but that did not make him amend his conduct. I myself sometimes whipped him; but then he ran away, and did not return again to the tent until it grew dark. Once, as I was about to dine, and had put the beans, which I had boiled for myself, upon a plate, I heard the voice of a bird with which I was not acquainted. I left my dinner standing, seized my gun, and ran out of the tent. After the space of about a quarter of an hour I returned, with the bird in my hand, but, to my astonishment, found not a single bean upon the plate. Kees had stolen them all, and taken himself out of the way. When he had committed any trespass of this kind, he used always, about the time when I drank tea, to return quietly, and seat himself in his usual place, with every appearance of innocence, as if nothing had happened; but this evening he did not let himself be seen. And, on the following day, also, he was not seen by any of us; and, in consequence, I began to grow seriously uneasy about him, and apprehensive that he might be lost for ever. But, on the third day, one of my people, who had been to fetch water, informed me that he had seen Kees in the neighbourhood, but that, as soon as the animal espied him, he had concealed himself again. I immediately went out and beat the whole neighbourhood with my dogs. All at once, I heard a cry, like that which Kees used to make, when I returned from my shooting, and had not taken him with me. I looked about, and at length espied him, endeavouring to hide himself behind the large branches of a tree. I now called to him in a friendly tone of voice, and made motions to him to come down to me. But he could not trust me, and I was obliged to climb up the tree to fetch him. He did not attempt to fly, and we returned together to my quarters; here he expected to receive his punishment; but I did nothing, as it would have been of no use. 
The Loyalty "An officer, wishing to put the fidelity of my of the baboon to the test, pretended to strike me. At Baboon. this he flew in a violent rage, and, from that time, could never endure the sight of the officer. If he only saw him at a distance he began to cry, and make all kinds of grimaces, which evidently showed that he wished to revenge the insult that had been done to me; he ground his teeth; and endeavoured, with all his might, to fly at his face, but that was out of his power, as he was chained down. The offender several times endeavoured, in vain, to conciliate him, by offering him dainties, but he remained long implacable.

The Intelligence of the

"When any eatables were pilfered, at my quarBaboon. was the accusation unfounded. For a time the eggs, which a hen laid me, were constantly stolen, and I wished to ascertain whether I had to attribute this loss also to him. For this purpose I went one morning to watch him, and waited till the hen announced, by her cackling, that she had laid an egg. Kees was sitting upon my vehicle; but, the moment he heard the hen's voice, he leapt down, and was running to fetch the egg. When he saw me, he suddenly stopped, and affected a careless posture, swaying himself backwards upon his hind legs, and assuming a very innocent look; in short, he employed all his art to deceive me with respect to his design. His hypocritical manœuvres only confirmed my suspicions, and, in order, in my turn, to deceive him, I pretended not to attend to him, and turned my back to the bush where the hen was cackling, upon which he immediately sprang to the place. I ran after him, and came up to him at the moment when he had broken the egg and was swallowing it. Having caught the thief in the fact, I gave him a good beating upon the spot, but this severe chastisement did not prevent his soon stealing fresh-laid eggs again. As I was convinced that I should never be able to 
break Kees off his natural vices, and that, unless I chained him up every morning, I should never get an egg, I endeavoured to accomplish my purpose in another manner; I trained one of my dogs, as soon as the hen cackled, to run t: the nest, and bring me the egg, without breaking it. In a few days, the dog had learned his lesson; but Kees, as soon as he heard the hen cackle, ran with him to the nest. A contest now took place between them, who should have the egg; often the dog was foiled, although he was the stronger of the two. If he gained the victory, he ran joyfully to me with the egg, and put it into my hand. Kees, nevertheless, followed him, and did not cease to grumble and make threatening grimaces at him, till he saw me take the egg,as if he was comforted for the loss of his booty by his adversary's not retaining it for himself. If Kees had got hold of the egg, he endeavoured to run with it to a tree, where, having devoured it, he threw down the shells upon his adversary, as if to make game of him. Kees was always the first awake in the morning, and, when it was the proper time, he awoke the dogs, who were accustomed to his voice, and, in general, obeyed, without hesitation, the slightest motions by which he communicated his orders to them, immediately taking their posts about the tent and carriage, as he directed them."

The Bonnet The bonnet monkey is of the genus macacus, Monkey. and is to be found in many parts of India. It is characterized by a bonnet, or cap of hair, which radiates from the centre of the crown. It is known as the Macacus Radiatus. Other species of the genus macacus are the Rhesus monkey, the Wanderoo, the Barbary Ape or Magot, and the Macaque.

Indian Monkeys. Many stories are told of the audacity of the Indian monkeys in which those of the genus macacus come in for more than honourable mention. Whether in their native haunts, or in European menageries, they are an 
endless source of amusement and not unfrequently one of annoyance. In their free state, they tax the ingenuity of native and European alike by their mischievous habits and thievish propensities. They climb upon the tops of the Bazaars and the slightest relapse from vigilance on the part of the shopkeepers is sure to be followed by the loss or spoliation of their wares. A common defence against these unwelcome intruders is to cover the roofs with a certain prickly shrub, the thorns of which command respect even from monkeys. Mrs. Bowdich says: "In some places they are even fed, encouraged, and allowed to live on the roofs of houses;" but this would be where the goods of the householder were beyond their reach. "If a man wishes to revenge himself for any injury committed upon him," says Mrs. Bowdich, "he has only to sprinkle some rice or corn upon the top of his enemy's house or granary just before the rain sets in, and the monkeys will assemble upon it, eat all they can find outside, and then pull off the tiles to get at that which has fallen through the crevices. This, of course, gives access to the torrents which fall in such countries, and house, furniture and stores are all ruined." Quoting from another writer, Mrs. Bowdich gives an amusing description of the way in which one of these monkeys watched his opportunity for making his descent upon a sweet-stuff shop. Taking up a position opposite the shop, "he pretended to be asleep, but every now and then softly raised his head to look at the tempting piles and the owner of them, who sat smoking his pipe without symptoms even of a doze. In half an hour the monkey got up, as if he were just awake, yawned, stretched himself, and took another position a few yards off, where he pretended to play with his tail, occasionally looking over his shoulder at the coveted delicacies. At length the shopman gave signs of activity, and the monkey was on the alert; the man went to his back room, the monkey cleared the street at one bound, and in an 
instant stuffed his pouches full of the delicious morsels. $\mathrm{He}$ had, however, overlooked some hornets, which were regaling themselves at the same time. They resented his disturbance, and the tormented monkey, in his hurry to escape, came upon a thorn-covered roof, where he lay stung, torn, and bleeding. He spurted the stolen bonbons from his pouches and barked hoarsely looking the picture of misery. The noise of the tiles which he had dislodged in his retreat brought out the inhabitants, and among them the vendor of the sweets, with his turban unwound, and streaming two yards behind him. All joined in laughing at the wretched monkey; but their religious reverence for him induced them to go to his assistance: they picked out his thorns and he limped away to the woods quite crestfallen."

The Monkey The writer, from whom Mrs. Bowdich quoted

Outdone. the above story, gives a graphic account of the success of a stratagem he employed to rid himself of the unwelcome visits of his monkey friends. "Although," says he, "a good deal shyer of me than they were of the natives, I found no difficulty in getting within a few yards of them; and when I lay still among the brushwood they gambolled round me with as much freedom as if I had been one of themselves. This happy understanding, however, did not last long, and we soon began to urge war upon each other. The casus belli was a field of sugar-cane which I had planted on the newly cleared jungle.

"Every beast of the field seemed leagued against this devoted patch of sugar-cane. The wild elephants came and browzed in it; the jungle hogs rooted it up, and munched it at their leisure; the jackals gnawed the stalks into squash; and the wild deer ate the tops of the young plants. Against all these marauders there was an obvious remedy,-to build a stout fence round the cane-field. This was done accordingly; and a deep. trench dug outside, that even the wild elephant did not deem it prudent to cross. The wild hogs 
came and inspected the trench and the palisades beyond. A bristly old tusker was observed taking a survey of the defences; but, after mature deliberation, he gave two short grunts, the porcine (language), I imagined, for 'No go,' and took himself off at a round trot, to pay a visit to my neighbour Ram Chunder, and inquire how his little plot of sweet yams was coming on. The jackals sniffed at every crevice, and determined to wait a bit; but the monkeys laughed the whole entrenchment to scorn. Day after day was I doomed to behold my canes devoured as fast as they ripened, by troops of jubilant monkeys. It was of no use attempting to drive them away. When disturbed, they merely retreated to the nearest tree, dragging whole stalks of sugar-cane along with them, and then spurted the chewed fragments in my face, as I looked up at them. This was adding insult to injury; and I positively began to grow bloodthirsty at the idea of being outwitted by monkeys. The case between us might have been stated in this way. ' $I$ have, at much trouble and expense, cleared and cultivated this jungle land,' said I. 'More fool you,' said the monkeys. 'I have planted and watched over these sugar-canes.' 'Watched! $\mathrm{Ah}$, ah! so have we, for the matter of that.' 'But surely I have a right to reap what I sowed.' 'Don't see it,' said the monkeys; 'the jungle, by rights prescriptive and indefeasible, is ours, and has been so ever since the days of Ram Hanumán of the long tail. If you cultivate the jungle without our consent, you must look to the consequences. If you don't like our customs, you may get about your business. We don't want you.' I kept brooding over this mortifying view of the matter, until one morning I hatched revenge in a practicable shape. A tree, with about a score of monkeys on it, was cut down, and half a dozen of the youngest were caught as they attempted to escape. A large pot of ghow (treacle) was then mixed with as much tarter emetic as could be spared from the medicine chest, and the young hopefuls 
after being carefully painted over with the compound, were allowed to return to their distressed relatives, who, as soon as they arrived, gathered round them and commenced licking them with the greatest assiduity. The results I had anticipated were not long in making their appearance. A more melancholy sight it was impossible to behold; but so efficacious was this treatment, that for more than two years I hardly ever saw a monkey in the neighbourhood."

The Monkey Tavernier was once travelling from Agra to Aroused. Surat with the English president, when passing within a few miles of Amenabad through a forest of mangoes, they experienced the danger of provoking such companies. $\mathrm{He}$ says. "We saw a vast number of very large apes, male and female, many of the latter having their young in their arms. We were each of us in our coaches; and the English president stopped his to tell me that he had a very fine new gun; and knowing that I was a good marksman, desired me to try it, by shooting one of the apes. One of my servants, who was a native of the country, made a sign to me not to do it; and I did all that was in my power to dissuade the gentleman from his design, but to no purpose; for he immediately levelled his piece, and shot a she ape, who fell through the branches of the tree on which she was sitting, her young ones tumbling at the same time out of her arms on the ground. We presently saw that happen which my servant apprehended; for all the apes, to the number of sixty, came immediately down from the trees, and attacked the president's coach with such fury that they must infallibly have destroyed him if all who were present had not flown to his relief, and by drawing up the windows, and posting all the servants about the coach, protected him from their resentment." That diplomacy is better than war in dealing with bands of monkeys is shown by comparing the results of the foregoing experiences. 
The Monkeys' That monkeys are capable of very poignant

Affection. feeling is shown by the following pathetic story. Mr. Forbes, in his "Oriental Memoirs," says :- "On a shooting party one of my friends killed a female monkey, and carried it to his tent, which was soon surrounded by forty or fifty of the tribe, who made a great noise, and in a menacing posture advanced towards it. On presenting his fowling-piece they retreated, but one stood his ground, chattering and menacing in a furious manner. He at length came close to the tent door, and finding that his threatenings were of no avail, began a lamentable moaning, and by every expression of grief and supplication seemed to beg the body of the deceased. On this it was given to him. He took it up in his arms, eagerly pressed it to his bosom, and carried it off in a sort of triumph to his expecting companions. The artless behaviour of this poor animal wrought so powerfully on the sportsmen that they resolved never more to level a gun at one of the monkey tribe."

American To visit the family of the Cebidæ we have to

Monkeys. cross the Atlantic Ocean, and here we find characteristics with which the monkeys of the East are unfamiliar, while we miss others which are common to the monkeys of the old world. In passing from East to West we lose the cheek-pouch characteristic and we find that of the prehensile tail. There are more than eighty species in the family of the Cebidæ, divided into ten genera and grouped in four sub-families. The first of the sub-families includes the monkeys with prehensile tails.

The Capuchin The capuchins belong to the genus Cebus

Monkey. which includes the majority of American monkeys. There are a number of species of which the Brown Capuchin (Brazil), the Wheeper Capuchin (Brazil), and the White-throated Capuchin (Central America) are the best known.

The spider The Spider Monkey is of the genus Ateles and Monkeys. is one of the best known of the Cebiræ family. 
In it the prehensile tail reaches its perfection. It is a remarkably sensitive organ, answering the purpose, as the Rev. J. G. Wood puts it, of "a fifth hand," being capable of use "for any purpose to which the hand could be applied," and for hooking out objects from places "where a hand could not be inserted." According to Mr. Wood they wrap their tails about them to protect themselves from cold, to which they are very sensitive, and hold on by them to the branches of trees with such tenacity that they remain suspended after death. The prehensile part of the tail is naked and of extreme sensibility. The tail is also used to preserve balance when walking erect, for which purpose it is thrown up and curled over. The appearance of these monkeys, as they leap from branch to branch in their native woods, swinging by their tails, and often hanging on to those of each other, until a living bridge is formed from tree to tree, is exceedingly picturesque.

The Howling The Howling Monkeys form the single genus

Monkeys. of the second sub-family of the Cebidæ-the genus Mycetes. There are a number of species, popularly known as the "Golden Howler," the "Black Howler," \&c. \&c. They are chiefly characteristic for the attribute to which they owe their name. The howl is a loud mournful cry which can be heard at a great distance, and is said by Wallace to proceed from the leader of the band-who howls for the whole company. These animals are larger and more clumsy than the spider monkeys and therefore less agile; they have powerful, prehensile tails. The "Howler "is much prized by the Indians as an article of food.

The Bearded The third sub-family of the Cebidx includes saks. some dozen species which inhabit the forests of Equatorial America. They are of the genus Pithecia, and some species have broad beards and bushy tails. The head of the Bearded Saki (Pithecia Satanas) has a singularly human appearance. 
The The fourth sub-family of the Cebidæ includes Douroucouli. several genera and a number of species, of these the Douroucouli (Nyctipithecus felinus) is one of the most interesting. It is a small monkey, measuring only thirteen inches, apart from its tail, which is eighteen inches long: It is catlike in some of its habits, sleeping during the day, and prowling about at night in search of food, which it finds in fruits, insects and small birds. It has a catlike mew, though it often makes a louder cry more resembling the noise of the jaguar.

The Marmosets. The fifth family of the quadrumana comprises the marmosets, of which there are two genera-the Hapale and the Midas. These are very small, measuring about eight inches without the tail, which is eleven inches long. The marmoset is one of the prettiest of the monkeys, and, though at first shy, soon becomes playful and affectionate. Marmosets are one of the few species that breed in confinement. Sir William Jardine describes a marmoset who gave birth to three offspring in Paris. One of these, for some reason, displeased her, and she killed it, but upon the others beginning to suck the maternal instinct awoke, and she became as affectionate as she was before careless. "The male seemed more affectionate and careful of them than the mother, and assisted in the charge. The young generally keep upon the back or under the belly of the female, and Cuvier observed, that when the female was tired of carrying them, she would approach the male with a shrill cry, who immediately relieved her with his hands, placing them upon his back, or under his belly, where they held themselves and were carried about until they became'restless for milk, when they were given over to the mother who, in her turn, would again endeavour to get rid of them."

SUB-ORDER II. The lemurs and their allied forms make up The Lemurs. the remaining families of the quadrumana. These are three. The Lemurida, of which there are many 
species, most of which belong to Madagascar, others to Africa, Asia, and the Indian Archipelago; the Tarsida, which hail from Sumatra and Borneo; and the Chiromyida, of which the ayeaye is the representative. The Lemurida are divided into four sub-families by Professor Mivart. I, the Indri; II, the true Lemurs; III, the slow Lemurs and IV, the Galagos. The lemur is nocturnal in its habits and noiseless in its movements. Some of its species much resemble the cat in appearance though its four hands unmistakably demonstrate its order. Sir William Jones describes a Slow Lemur (Nycticebus tardigradus), which he had in his possession, as "gentle except in the cold season, when his temper seemed wholly changed." This animal expressed great resentment when disturbed unseasonably. From half an hour after sunrise to half an hour before sunset he slept without any intermission, rolled up like a hedgehog: and as soon as he awoke he began to prepare himself for the occupations of his approaching day, licking and dressing himself like a cat-an operation which the flexibility of his neck and limbs enabled him to perform very completely. He was' then ready for a slight breakfast, after which he commonly took a short nap; but when the sun was quite set he recovered all his vivacity. "Generally he was not voracious, but of grasshoppers he never could have enough; and passed the whole night during the hot season in prowling for them. He used all his paws indifferently as hands." Mrs. Bowdich tells of one of these animals, procured by Mr. Baird at Prince of Wales Island, who shared a cage with a dog to whom he became greatly attached, while nothing could reconcile him to a cat, which constantly jumped over his back, causing him great annoyance. The Tarsier. The tarsier (Tarsius spectrum) is a small, kittenfaced animal with long hind legs, which enable it to leap like a frog. It is nocturnal in habit, and is found in Sumatra, Borneo, and elsewhere.

The Aje-Aje. The aye-aye (Chiromys madagascariensis) is 
a remarkable little animal resembling, as Professor Owen says, in size and shape the domestic cat, its head and ears being larger, and its hind legs and tail longer than those of the cat. Dr. Sandwich, writing of one he had in his possession, says:- "The thick sticks I put into his cage were bored in all directions by a large and destructive grub, called the montouk. Just at sunset the aye-aye crept from under his blanket, yawned, stretched and betook himself to his tree. Presently he came to one of the worm-eaten branches, which he began to examine most attentively, and bending forward his ears, and applying his nose close to the bark, he rapidly tapped the surface with the curious second digit, as a woodpecker taps a tree, though with much less noise, from time to time inserting the end of the slender finger into the worm-holes as a surgeon would a probe. At length he came to a part of the branch which evidently gave out an interesting sound, for he began to tear it with his strong teeth. He rapidly stripped off the bark, cut into the wood, and exposed the nest of a grub which he daintily picked out of its bed, with the slender, tapping finger, and conveyed the luscious morsel to his mouth. But I was yet to learn another peculiarity. I gave him water to drink in a saucer, on which he stretched out his hand, dipped a finger into it and drew it obliquely through his open mouth. After a while he lapped like a cat, but his first mode of drinking appeared to me to be his way of reaching water in the deep clefts of trees."

ORDER II. The animals which most nearly resemble the Wing-Handed four-handed animals or quadrumana are the Animals. wing-handed animals, -the bats or Cheiroptera. These are of singular appearence and interesting habit. "If," says the Rev. J. G. Wood, "the fingers of a man were to be drawn out like wire to about four feet in length, a thin membrane to extend from finger to finger, and another membrane to fall from the little finger to the ankles; he would make a very tolerable imitation of a bat." - Of course, 

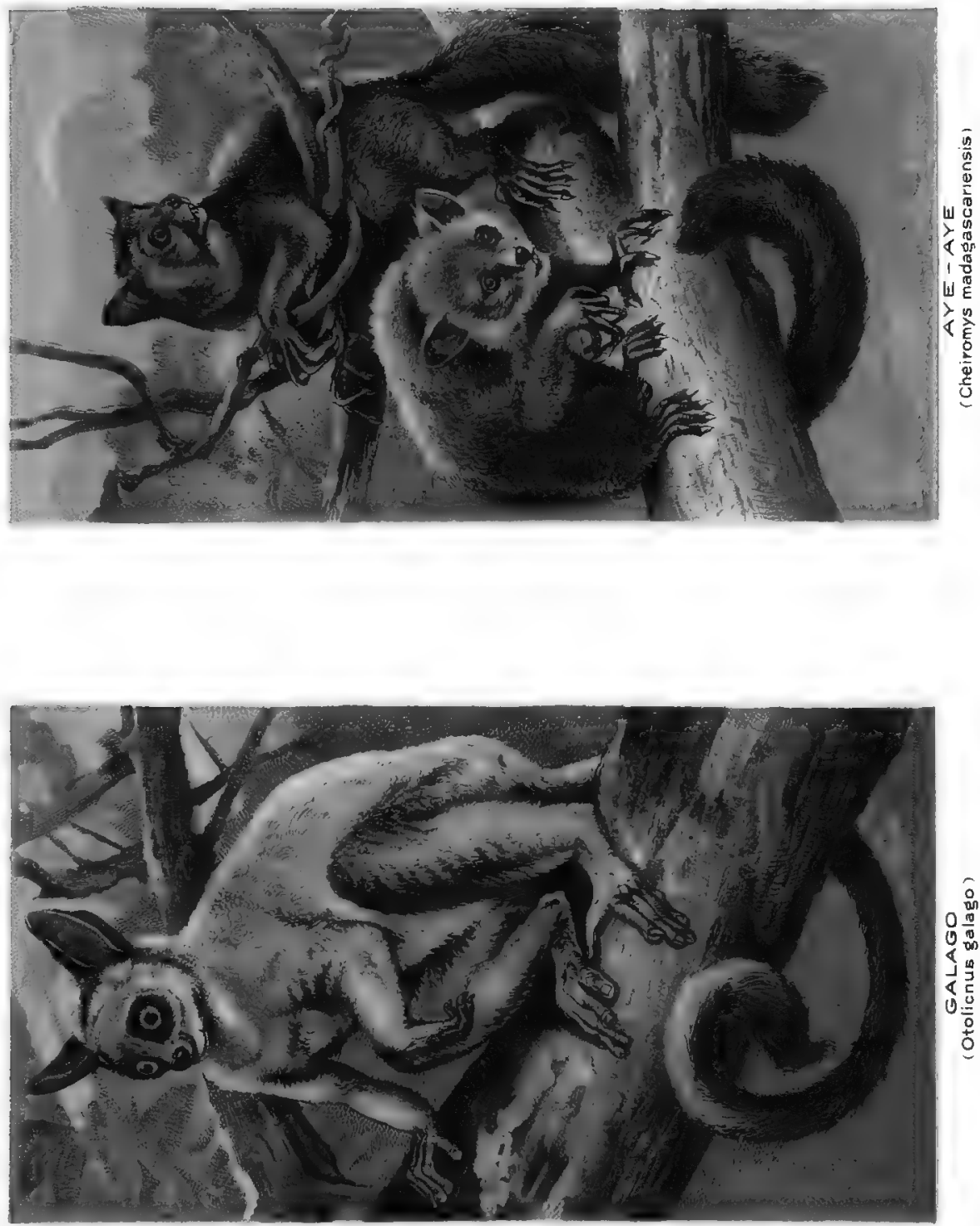
Digitized by Microsofte 
it should be added, making allowance for proportion, the full grown male bat, of the largest species, rarely exceeding twelve inches in height from head to foot. Bats' wings are highly nervous and sensitive, so much so as to render their owners almost independent of sight. Besides being "well adapted for flight," says Dr. Percival Wright, "they are still capable in a small measure of seizing, differing thus from the anterior limbs of Birds."

Bats. Dr. Dobson divides the order Cheiroptera into two sub-orders: I, The Great Bats and II, The Smaller Bats. Of these there are numerous genera and a large number of species. The Great Bats abound in the tropical and subtropical regions of the East, where they live on fruit, and from this circumstance are classified as "fruit-eating bats," though they are sometimes called "flying-foxes." The largest of these inhabit Sumatra and Java, living in large companies, sleeping by day and foraging by night. A large tree serves them for a sleeping-chamber, where, suspending themselves head downwards from the branches, they wrap their wings about them in lieu of blankets and sleep out the sunshine. After sunset they gradually awake and proceed to ravage any fruit preserves which may be within reach, committing serious depredations while the owners outsleep the moon. According to Mr. Francis Day, "they do very great injury to cocoa-nut plantations and mangoe gardens." "Their habits," says Mr. Day, "are very intemperate, and they often pass the night drinking the toddy from the chatties in the cocoa-nut trees, which results either in their returning home in the early morning in a state of extreme and riotous intoxication, or in being found the next day at the foot of the trees, sleeping off the effects of their midnight debauch." The Smaller Bats include several families, numerous genera, and a large number of species to be found in almost all parts of the world. These bats are chiefly insect-eaters, though included among them are the vampire bats and the 
Megaderma lyra which have the reputation of being cannibalistic. The various families are "The Horseshoe Bats," "The Nycteridæ," "The Vespertilionidæ," "The Emballonuridæ," and "The Phyllostomidæ.

The

The common English bats belong to the Common Vespertilionidx. The Pipistrelle feeds upon English Bats. insects but will eat flesh if opportunity serves. In his "Natural History of Selbourne," Mr. White describes a tame bat which he saw, which would take flies out of a person's hand. "If you gave it anything to eat," he says, "it brought its wings round before the mouth, hovering and hiding its head in the manner of birds of prey when they feed. The adroitness it showed in shearing off the wings of the flies, which were always rejected, pleased me much. Insects seemed to be most acceptable, though it did not refuse raw flesh when offered; so that the notion that bats go down chimneys and gnaw men's bacon seems no improbable story." The Long-eared Bat, Plecotus auritus, is also common in England. "Its ears," says Mr. Wood, "are about an inch and a half in length and have a fold in them reaching almost to the lips," hence its name. "It is very easily tamed."

The

The Vampire Bat which belongs to South

Vampire America has been invested with a halo of romance Bat.

by the stories which have been told about its sanguinary character. "It lives," says the Rev. J. G. Wood, " on the blood of animals, and sucks usually while its victim sleeps. The extremities, where the blood flows freely, as the toe of a man, the ears of a horse, or the combs and wattles of fowls, are its favourite spots. When it has selected a subject, on which it intends to feed, it watches until the animal is fairly asleep. It then carefully fans its victim with its wings while it bites a little hole in the ear or shoulder, and through this small aperture, into which a pin's head would scarcely pass, it contrives to abstract sufficient blood to make a very ample meal. The wound is so small, and 
the bat manages so adroitly, that the victim does not discover that anything has happened until the morning, when a pool of blood betrays the visit of the vampire. "The Vampire Bat," says Professor Darwin, "is often the cause of much trouble by biting the horses on their withers. The injury is not so much owing to the loss of blood, as to the inflammation which the pressure of the saddle afterwards produces. The whole circumstance has lately been doubted in England. I was therefore fortunate in being present when one was actually caught on a horse's back. We were bivouacking late one evening, near Coquimbo, in Chili, when my servant, noticing that one of the horses was very restive, went to see what was the matter, and fancying he could distinguish something, suddenly put his hand on the beast's withers, and secured the vampire. In the morning the spot where the bite had been inflicted was easily distinguished by its being slightly swollen and bloody. The third day afterwards we rode the horse without any ill effects."

A Traveller's Captain Steadman, in his "Narrative of a Five Experience. Years' Expedition against the Revolted Negroes of Surinam," relates, that on waking about four o'clock one morning in his hammock, he was extremely alarmed at finding himself weltering in congealed blood, and without feeling any pain whatever. "The mystery was," continues Captain Steadman, "that I had been bitten by the Vampyre or Spectre of Guiana, which is also called the Flying Dog of New Spain, and by the Spaniards, Perrovolador. This is no other than a bat of monstrous size, that sucks the blood from men and cattle while they are fast asleep, even sometimes till they die; and as the manner in which they proceed is truly wonderful, I shall endeavour to give a distinct account of it. Knowing, by instinct, that the person they intend to attack is in a sound slumber, they generally alight near the feet, where, while the creature continues fanning with his enormous wings, which keeps one cool, he bites a piece out of the tip of the 
great toe, so very small, indeed, that the head of a pin could scarcely be received into the wound, which is consequently not painful; yet through this orifice he continues to suck the blood until he is obliged to disgorge. Cattle they generally bite in the ear, but always in places where the blood flows spontanzously."

Megaderma The Vampire Bat of South America has long

Iyra. been credited with sanguinivorous habits, and until recently was supposed to be the only bat having such propensities. Mr. Edward Blyth has, however, shown that the Megaderma Lyra of Asia will sometimes prey upon the smaller species of bat with which it comes in contact. Mr. Biyth, one evening, observed a rather large bat of this species enter an outhouse, whereupon he procured a light, closed the door to prevent escape and then proceeded to catch the intruder. In the chase the bat dropped what Mr. Blyth at first took to be a young one, but which proved to be a small Vespertilio Bat, "feeble from loss of blood, which it was evident the Megaderma had been sucking from a large, and still bleeding, wound under and behind the ear." As the Megaderma had not alighted while in the outhouse, Mr. Blyth ccncluded "that it sucked the vital current from its victim as it flew, having probably seized it on the wing, and that it was seeking a quiet nook where it might devour the body at leisure." Having caught the Megaderma Mr. Blyth kept both specimens until the next day, and having examined each separately put them both into a cage, whereupon the Megaderma attacked the smaller bat "with the ferocity of a tiger"; finding it impossible to escape the cage "it hung by the hind legs to one side of its prison, and after sucking the victim till no more blood was left commenced devouring it, and soon left nothing but the head and some portions of the limbs." "The voidings observed shortly afterwards in its cage," says Mr. Blyth, "resembled clotted blood, which will explain the statement of Steadman and 
others concerning masses of congealed blood being observed near a patient who has been attacked by a South American vampire."

ORDER III. Insect-eating animals (Insectivora) include Insect-Tfating several families, of which the hedgehogs, the Animals. moles and the shrews, are the best known genera. The Colugo is perhaps the most singular member of the order. According to some writers his proper place is among the lemurs, and except that his feet are adorned with claws instead of nails, it is easy to understand why he might be classed with the quadrumana. The Colugo is covered from head to foot by a furry membrane, resembling an overcoat open in front and ending in a three cornered flap at the tail.

The

The family of the hedgehog contains two genera

Hedgehog. and a number of species. Its length is from six to ten inches; the head, back, and sides being covered with short spines, the under parts with soft hair. It lives in thickets, and subsists on fruits, roots, and insects. During the winter, it lies imbedded in moss, or dried leaves, in a state of torpidity. It inhabits Europe, Asia and Africa. It is valuable in the garden for destroying the insects, and in the kitchen for the extermination of cockroaches, beetles and other household pests. For defence, it rolls itself into a ball in such a manner as to present its prickly spines on all sides. In this condition it can suffer considerable violence without injury. Mr. Bell mentions a hedgehog that was in the habit of running to the edge of an area wall twelve or fourteen feet high, and without a moment's pause, leap over, contracting into a ball as he fell, and in this form reaching the ground, where it quietly unfolded itself as if nothing had happened and ran on its way. It is nocturnal in its habits and in its natural state lives in pairs. It is easily tamed. A hedgehog has been trained to serve as a turnspit "as well," says Captain Brown, "in all respects as the dog of that denomination. In 
a wild state it has been known to attack and kill a leveret. In attacking a snake it will roll itself up between its bites and thus protect itself against retaliation.

The Mole. The family of the Talpidæ to which the mole belongs is a large and interesting one. The common mole "when at rest," says the author of "Tales of Animals," "bears more resemblance to a small stuffed sack than to a living animal, its head being entirely destitute of external ears, and elongated nearly to a point, and its eyes so extremely small and completely hidden by the fur, that it would not be surprising should a casual observer conclude it to be blind. This apparently shapeless mass is endowed with great activity and a surprising degree of strength, and is excellently suited for deriving enjoyment from the peculiar life it is designed to lead. It is found abundantly in Europe and North America, from Canada to Virginia; often living at no great distance from water-courses, or in dykes thrown up to protect meadows from inundation. The mole burrows with great quickness, and travels under ground with much celerity; nothing can be better constructed for this purpose than its broad and strong hands, or fore paws, armed with long and powerful claws, which are very sharp at their extremities, and slightly curved on the inside. Numerous galleries, communicating with each other, enable the mole to travel in various directions, without coming to the surface, which they appear to do very rarely, unless their progress is impeded by a piece of ground so hard as to defy their strength and perseverance. The depth of their burrows depends very materially on the character of the soil, and the situation of the place; sometimes running for a great distance, at a depth of from one to three inches, and sometimes much deeper. Moles are most active early in the morning, at midday, and in the evening; after rains they are particularly busy in repairing their damaged galleries; and in long continued wet weather we find that they seek the high grounds for security." 
An Interprising Though as Captain Brown points out nothing Mole. is more fatal to the mole than excessive rain, which fills their subterranean galleries with water; the following statement made by Mr. A. Bruce in the Linnæan Transactions, shows that the animal is not without enterprise on the water:- "On visiting the Loch of Clunie, which I often did, I observed in it a small island at the distance of one hundred and eighty yards from the nearest land, measured to be so upon the ice. Upon the island, the Earl of Airly, the proprietor, has a castle and small shrubbery. I remarked frequently the appearance of fresh mole casts, or hills. I for some time took them for those of the water mouse, and one day asked the gardener if it was so. No, said he, it was the mole; and that he had caught one or two lately. Five or six years ago, he caught two in traps; and for two years after this he had observed none. But, about four years ago, coming ashore one summer's evening in the dusk, with the Earl of Airly's butler, they saw at a short distance, upon the smooth water, some animal paddling towards the island. They soon closed with this feeble passenger, and found it to be the common mole, led by a most astonishing instinct from the castle hill, the nearest point of land, to take possession of this desert island. It had been, at the time of my visit, for the space of two years quite free from any subterraneous inhabitant; but the mole has, for more than a year past, made its appearance again, and its operations I have since been witness to."

The Une of The use of the mole is often said to be far

the Mole. outweighed by the mischief he perpetrates, the truth appearing to be that like many other animals, in his own place he is valuable, out of it he is a source of danger. Both conditions are illustrated by the following, which I quote from Mrs. Bowdich's "Anecdotes of Animals."

"A French naturalist of the name of Henri Lecourt devoted a great part of his life to the study of the habits and struc- 
ture of moles; and he tells us that they will run as fast as a horse will gallop. By his observations he rendered essential service to a large district in France; for he discovered that numbers of moles had undermined the banks of a canal, and that unless means were taken to prevent the catastrophe, these banks would give way, and inundation would ensue. By his ingenious contrivances and accurate knowledge of their habits, he contrived to extirpate them before the occurrence of further mischief. Moles, however, are said to be excellent drainers of land; and Mr. Hogg, the Ettrick Shepherd, used to declare that if a hundred men and horses were employed to dress a pasture farm of 1500 or 2000 acres, they would not do it as effectually as moles would do, if left to themselves."

The shrew. The shrew family is a large one and widely distributed over the surface of the earth. The common shrew (Sorex vulgaris) is that best known in England. It resembles the mouse in general form and varies in size and colour, its usual length, including the tail being about four and a half inches. Its body is moderately full, its neck short, its head tapering to a pointed snout, the fore-feet small, the hind-feet larger and the tail shorter than the body. The shrew is generally found either in burrows, or among heaps of stones, or in holes made by other animals; near dung heaps or hayricks, they are more numerous than elsewhere. Insects are their principal subsistence, but they seem no less fond of grain, and show a pig's predilection for filth of various sorts. Its principal enemies are the Kestrel and the Barn Owl. A superstition to the effect that if the shrew should run over the legs of a cow or a horse while reposing on the grass it causes lameness, is also responsible for the destruction of many by ignorant country folk. One species of the shrew enjoys the reputation of being the smallest living mammel; it is but an inch and a half long with a tail of an inch in length. The water shrew is somewhat larger than the common shrew 
attaining to a length of five and a half inches including the tail. The water shrew colonises on the banks of rivers.

ORDER IV. The order of flesh-eating animals (casnivora) Flesh-eating includes a large number of species among which Animals. are the lion, the tiger and the leopard, as well as the cat and the dog. The two sub-orders into which this order is divided are: I, The Fissipedia, and II, The Pinnipedia. The Fissipedia are again divided into ten families; lions, cats, dogs, hyenas, weasels, and bears being the most important members. The Pinnipedia includes the seal, the sea lion, the walrus and their allies.

Animals of the cat kind are distinguished SUB-ORDER I. by their sharp and formidable claws, which Animals of the they can hide or extend at pleasure. They

Cat Kind. are remarkable for their rapacity, subsisting entirely on the flesh and blood of other animals. The dog, wolf, and bear, are sometimes known to live on vegetables, or farinaceous food; but the lion, the tiger, the leopard, and other animals of this class, devour nothing but flesh, and would starve upon any other provision. They lead a solitary, ravenous life, uniting neither for mutual defence, like vegetable feeders, nor for mutual support, like those of the dog kind. The first of the class is the lion, distinguished from all the rest by his strength, his magnitude, and his mane. The second is the tiger, rather longer than the lion, but not so tall, and known by the streaks and vivid beauty of its skin; here we may also mention the puma, which is sometimes called a panther, or colloquially a "painter", otherwise a couguar, or American lion, which is of a tawny colour. The next is the leopard, sometimes called a panther, and the next the jaguar, followed by the ounce, not so large as any of the former, spotted like them, but distinguished by the creamcoloured ground of its hair, and a tail so long as to exceed the length of its body. The next is the catamountain, or tiger-cat, less than the ounce, but differing particularly in 
having a shorter tail, and being streaked down the back like a tiger. The next is the lynx, of the size of a fox, with iis body streaked, and the tips of its ears tufted with black. Then comes the Persian lynx, not so large as the lynx, nor mottled like it, but with longer ears, tipped also with black, and the serval, shaped and streaked like the lynx, but not having the tips of its ears tufted. Lastly, the cat, wild and tame, with all its varieties; less than any of the former, but like them insidious, rapacious, and cruel.

The Lion. The lion is known as the King of Beasts; though modern travellers have done much to rob him of the homage that he once received. Like a human being who has been too much lionized, he suffers from the detractions which are excited by his pre-eminence. $\mathrm{He}$ is found chiefly in India and Africa, though he once had a more extended range. $\mathrm{He}$ was well known to the Greeks, and appears in both their poetry and history. Homer celebrates him, and according to Herodotus he exploited himself by attacking the camels of the army of Xerxes. His noble appearance is said to be responsible for the popular ideal of his character, which travellers and naturalists declare to be minus the magnanimous and generous qualities with which it was at one time credited.

The Lion's In judging of the lion's character it is importCharacter. ant to remember that he belongs to the cat family, and that his virtues and vices are naturally of the cat kind. "The lion seldom runs," says the author of "Tales of Animals." " $\mathrm{He}$ either walks or creeps, or, for a short distance, advances rapidly by great bounds. It is evident, therefore, that he must seize his prey by stealth; that he is not fitted for an open attack; and that his character is necessarily that of great power, united to considerable skill and cunning in its exercise." Again, the lion, as well as others of the cat tribe, takes his prey at night; and it is necessary, therefore, that he should have peculiar organs of vịsion. In all those 


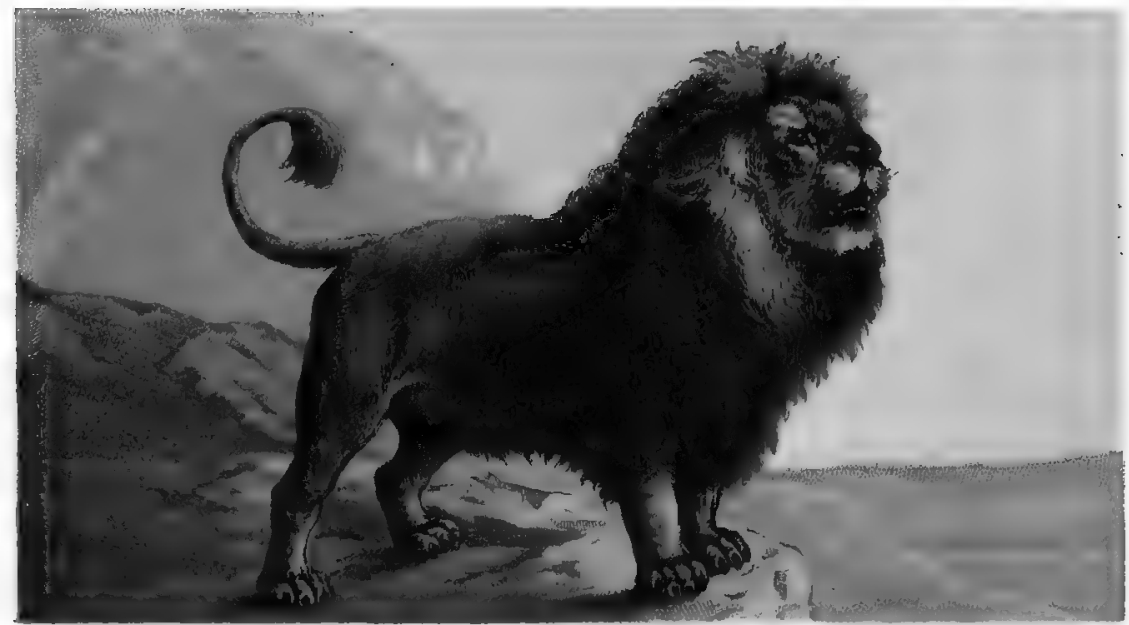

LION

(Felisleo)

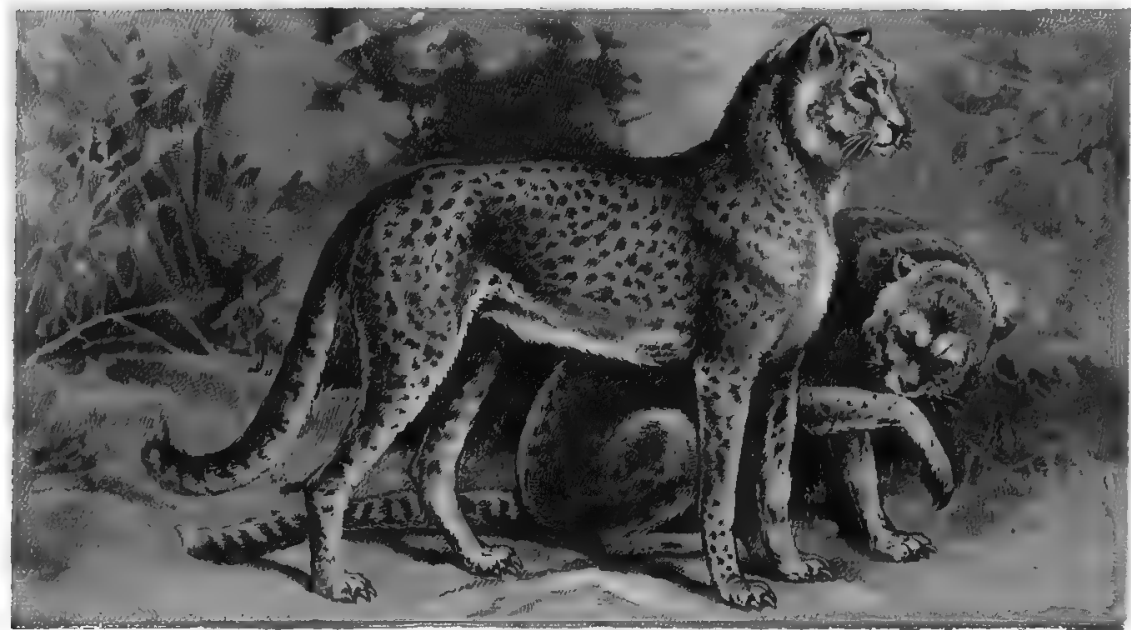


Digitized by Microsofte 
animals which seek their food in the dark, the eye is usually of a large size, to admit a great number of rays. This peculiar kind of eye, therefore, is necessary to the Lion to perceive his prey, and he creeps towards it with a certainty which nothing but this distinct nocturnal vision could give." Men who hunt the lion in the daytime, when he is usually sleeping off the effects of a hearty meal, and who awaken him in a surprised and dazed condition when his cat-like eyes cannot bear the blaze of the sun, ought not to be surprised if he tries to postpone fighting until a more convenient season. Nor can he be said to be less noble because he only fights when it is necessary to procure food, to protect his young, and to defend himself. A veritable Ulysses among the beasts he is ready to fight if needs be, but unless urged by hunger, or attacked by the hunter, he does not seem to bear any particular malice against mankind.

The Lion's "It is singular," says Sparrman, "that the lion,

Attitude which, according to many, always kills his prey towards Man. immediately if it belongs to the brute creation, is reported, frequently, although provoked, to content himself with merely wounding the human species; or, at least, to wait some time before he gives the fatal blow to the unhappy victim he has got under him. A farmer, who the year before had the misfortune to be a spectator of a lion seizing two of his oxen, at the very instant he had taken them out of the waggon, told me that they immediately fell down dead upon the spot, close to each other; though, upon examining the carcasses afterwards, it appeared that their backs only had been broken. In several places through which I passed, they mentioned to me by name a father and his two sons, who were said to be still living, and who, being on foot near a river on their estate, in search of a lion, this latter had rushed out upon them, and thrown one of them under his feet. The two others, however, had time enough to shoot the lion dead upon the spot, which had 
lain almost across the youth, so nearly and dearly related to them, without having done him any particular hurt. I myself saw, near the upper part of Duyvenhoek River, an elderly Hottentot who, at that time (his wounds being still open), bore under one eye, and underneath his cheek bone the ghastly marks of the bite of a lion, which did not think it worth his while to give him any other chastisement for having, together with his master (whom I also knew), and several other Christians, hunted him with great intrepidity, though without success. The conversation ran everywhere in this part of the country upon one Bota, a farmer and captain in the militia, who had lain for sometime under a lion, and had received several bruises from the beast, having been at the same time a good deal bitten by him in one arm, as a token to remember him by; but, upon the whole, had, in a manner, had his life given him by this noble animal. The man was said then to be living in the district of Artaquaskloof."

Discretion the The following seems to show a curious power better part of of reasoning on the part of the lion. "Diederik

Valour. Muller, one of the most intrepid and successful of modern lion-hunters in South Africa, had," says Sir William Jardine, "been out alone hunting in the wilds, when he came suddently upon a lion, which, instead of.giving way, seemed disposed, from the angry attitude he assumed, to dispute with him the dominion of the desert. Diederik instantly alighted, and confident of his unerring aim levelled his gun at the forehead of the lion, who was couched in the act to spring, within fifteen paces of him; but at the moment the hunter fired, his horse, whose bridle was round his arm, started back and caused him to miss. The lion, bounded forward, but stopped within a few paces, confronting Diederik who stood defenceless, his gun discharged, and his horse running off. The man and the beast stood looking at each other in the face for a short space. At length the lion 
moved backward as if to go away. Diederik began to load his gun, the lion looked over his shoulder, growled, and returned. Diederik stood still. The lion again moved cautiously off, and the Boer proceeded to load and ram down his bullet. The lion again looked back and growled angrily; and this occurred repeatedly, until the animal had got off to some distance when he took fairly to his heels and bounded away."

The strength Whatever may be said of the lion's courage, of the there can be no doubt as to his strength. Burchell

Lion. thus describes an encounter with a lion. "The day was exceedingly pleasant and not a cloud was to be seen. For a mile or two we travelled along the banks of the river, which in this part abounded in late mat-rushes. The dogs seemed much to enjoy prowling about and examining every rushy place, and at last met with some object among the rushes which caused them to set up a most vehement and determined barking. We explored the spot with caution as we suspected, from the peculiar tone of the bark, that it was what it proved to be-lions. Having encouraged the dogs to drive them out, a task which they performed with great willingness, we had a full view of an enormous black-maned lion and lioness. The latter was seen only for a minute, as she made her escape up the river under concealment of the rushes; but the lion came steadily forward, and stood still and looked at us. At this moment we felt our situation not free from danger, as the animal seemed preparing to spring upon us, and we were standing on the bank, at a distance of only a few yards from him, most of us being on foot, and unarmed, without any visible possibility of escaping. At this instant the dogs boldly flew in between us and the lion, and surrounding him, kept him at bay by their violent and resolute barking. The lion, conscious of his strength, remained unmoved at their noisy attempts and kept his head turned towards us. At one moment, the dogs perceiving his eye 
thus engaged, had advanced close to his feet, and seemed as if they would actually seize hold of him; but they paid dearly for their imprudence, for, without discomposing the majestic and steady attitude in which he stood fixed, he merely moved his paw, and the next instant I beheld two lying dead. In doing this he made so little exertion, that it was scarcely perceptible by what means they had been killed. We fired upon him, and one of the balls went through his side, just between the short ribs, but the animal still remained standing in the same position. We had now no doubt that he would spring upon us, but happily we were mistaken and were not sorry to see him move slowly away."

The Lion's Many instances are on record of strong Affection. attachments formed by the lion for his keeper, and for dogs or other animals which have been associated with him. A remarkable example of this kind is related, where a little dog, which had been thrown into a lion's den that he might be devoured, was not only spared by the noble animal, but became his companion and favourite. In a moment of irritation caused by long hunger, the dog, having snapped at the first morsels of food, received a blow from the lion which proved fatal. From that time the lion pined away, refused his food, and at length died, apparently of melancholy.

The Lion's A carpenter was employed some years ago to

Docility. do some repairs to the cage of a lion at a menagerie at Brussels. When the workman saw the lion he drew back in terror. The keeper, on this, entered the cage and led the animal to the upper part of it, while the lower was refitting. He there amused himself for some time playing with the lion, and being wearied he fell asleep. The carpenter, having finished his work, called the keeper to inspect what he had done, but the keeper made no answer. Having repeatedly called in vain he became alarmed and proceeded to the upper part of the cage, where, looking 
through the bars, he saw the lion and the keeper lying side by side, and immediately uttered a loud cry. The lion started up and stared at the carpenter with an eye of fury, and then, placing his paw on the breast of his keeper, lay down to sleep again. The carpenter, terrified at what he saw, ran off to secure help, whereupon some of the attendants succeeded in arousing the keeper who, far from being disconcerted by the circumstances, took the paw of the lion and shook it gently in token of regard and the animal quietly returned with him to his former residence. M. Felix, the keeper of the animals at Paris, had charge of a lion which refused food, and became sullen and mopish during the temporary absence of M. Felix through illness, but who regained his spirits and showed every demonstration of joy upon the reappearance of M. Felix at his post of duty.

The story of With so many authentic instances which can Androcles. be cited of the amenability of the lion to kindly influences, the story of Androcles and the lion does not seem so improbable as it has been sometimes thought. The following is the story:-In the days of ancient Rome, a Roman governor treated one of his slaves or subjects, called Androcles, so cruelly that he ran away. To escape pursuit he fled to a desert and crept into a cave. What was his horror to find that this cave was a lion's den, and to see a large lion approach him! He expected instantly to be destroyed; but the lion, approaching Androcles, held up his paw or foot with a supplicating air. Androcles examined the lion's paw, and found a thorn in it which he drew out, and the lion, apparently relieved, fawned upon his benefactor as a dog does upon his master. After some time Androcles ventured back to the place where he lived before. He was discovered, taken up as a runaway slave, and conclemned to be the prey of a wild beast. $\mathrm{He}$ was accordingly thrown into a place where a large lion, recently caught, was let in upon him. The lion came bounding toward Androcles, and the spec- 
tators expected to see the man instantly torn in pieces. What was their astonishment to see the lion approach him, and fawn before him like a dog who had found his master! It was the lion Androcles had met in the desert, and the grateful animal would not rend his benefactor.

A Lion Hunt. Livingstone came to very close quarters with a lion on one occasion, the circumstances of which he thus narrates. "The Bakátla of the village Mabotsa, were much troubled by lions, which leaped into the cattle-pens by night and destroyed their cows. They even attacked the herds in open day. This was so unusual an occurrence that the people believed that they were bewitched, 'given' as they said, into the power of the lions by a neighbouring tribe. They went once to attack the animals, but being rather a cowardly people compared to Bechuanas in general on such occasions, they returned without killing any. It is well known that if one in a troop of lions is killed, the others take the hint and leave that part of the country. So the next time the herds were attacked, I went with the people in order to encourage them to rid themselves of the annoyance by destroying one of the marauders. We found the lions on a small hill, about a quarter of a mile in length and covered with trees. A circle of men was formed round it, and they gradually closed up, ascending pretty near to each other. Being down below on the plain with a native schoolmaster, named Mebálwe, I saw one of the lions sitting upon a piece of rock, within the now closed circle of men. Mebálwe fired at him before I could, and the ball struck the rock upon which the animal was sitting. He bit at the spot struck, -as a dog does at a stick or a stone thrown at him, then, leaping away, broke through the opening circle and escaped unhurt. When the circle was reformed we saw two other lions in it, but we were afraid to fire lest we should strike the men; and they allowed the beasts to burst through also. If the Bakatla had acted according to the custom of the 
country, they would have speared the lions in their attempt to get out. Seeing that we could not get them to kill one of the lions, we bent our footsteps towards the village; in going round the end of the hill, however, I saw one of the beasts sitting on a piece of rock, as before, but this time he had a little bush in front. Being about thirty yards off, I took a good aim at his body through the bush, and fired both barrels into in. The men then called out: 'He is shot! $\mathrm{He}$ is shot!' Others cried: 'He has been shot by another man, too ; let us go to him.' I did not see anyone else shoot at him, but I saw the lion's tail erected in anger behind the bush, and turning to the people, said : 'Stop a little till I load again.' When in the act of ramming down the bullets I heard a shout. Starting, and looking half round, I saw the lion just in the act of springing upon me. I was upon a little height. He caught my shoulder as he sprang and we both came to the ground below together. Growling horribly, close to my ear, he shook me as a terrier dog does a rat. The shock produced a stupor, similar to that which seems to be felt by a mouse after the first shake of a cat. It caused a sort of dreaminess, in which there was no sense of pain or feeling of terror, though quite conscious of all that was happening. It was like what patients partially under the influence of chloroform describe, who see all the operation but feel not the knife. This singular condition was not the result of any mental process. The shake annihilated fear, and allowed no sense of horror in looking round at the beast. This peculiar state is probably produced in all animals killed by the carnivora; and, if so, is a merciful provision by our benevolent Creator for lessening the pain of death. Turning round to relieve myself of the weight, as he had one paw on the back of my head, I saw his eyes directed to Mebálwe, who was trying to shoot him at a distance of ten or fifteen yards. His gun, a flint one, missed fire in both barrels. The lion immediately left me and attacking Mebálwe bit his 
thigh. Another man, whose life I had saved before, after he had been tossed by a buffalo, attempted to spear the lion while he was biting Mebálwe. He left Mebálwe and caught this man by the shoulder; but at that moment the bullets he had received took effect, and he fell down dead. The whole was the work of a few moments, and must have been his paroxysm of dying rage. In order to take out the charm from him, the Bakátla, on the following day, made a huge bonfire over the carcass, which was declared to be the largest lion they had ever seen. Besides crunching the bone into splinters, he left eleven teeth wounds on the upper part of my arm. A wound from this animal's tooth resembles a gunshot wound. It is generally followed by a great deal of sloughing and discharge, and pains are felt in the part periodically ever after. I had on a tartan jacket on the occasion, and I believe that it wiped off all the virus from the teeth that pierced the flesh; for my two companions in this affray have both suffered from the peculiar pains, while I have escaped with only the inconvenience of a false joint in my limb."

A Thrilling Professor Lichtenstein, in his "Travels" gives a \#xperience. thrilling story of a Boer's adventure with a lion, which he had from the lips of the Boer himself. "It is now," said the colonist, "more than two years since, in the very place where we stand, I ventured to take one of the most daring shots that ever was hazarded. My wife was sitting within the house near the door, the children were playing about her, and I was without, near the house, busied in doing something to a waggon, when suddenly, though it was mid-day, an enormous lion appeared, came up and laid himself quietly down in the shade upon the very threshold of the door. My wife, either frozen with fear, or aware of the danger of attempting to fly, remained motionless in her place, while the children took refuge in her arms. The cry they uttered attracted my attention, and I hastened towards 
the door, but my astonishment may well be conceived when I found the entrance to it barred in such a way. Although the animal had not seen me, unarmed as I was escape seemed impossible, yet I glided gently, scarcely knowing what I meant to do, to the side of the house, up to the window of my chamber, where I knew my loaded gun was standing. By a most happy chance, I had set it into the corner close by the window, so that I could reach it with my hand; for, as you may perceive, the opening is too small to admit of my having got in, and still more fortunately, the door of the room was open, so that I could see the whole danger of the scene. The lion was beginning to move. There was no longer any time to think; I called softly to the mother not to be alarmed, and invoking the name of the Lord, fired my piece. The ball passed directly over the hair of my boy's head and lodged in the forehead of the lion, immediately above his eyes and stretched him on the ground, so that he never stirred more." "Indeed," says Professor Lichtenstein, "we all shuddered as we listened to this relation. Never, as he himself observed, was a more daring attempt hazarded. Had he failed in his aim, mother and children were all inevitably lost; if the boy had moved he had been struck; the least turn in the lion and the shot had not been mortal to him; and to consummate the whole, the head of the creature was in some sort protected by the door-post."

Attaoked by In Phillips's "Researches in South Africa," the a Iion. following account is given of the adventures of a traveller which we quote from Jardine's Naturalists' Library collated with other versions. "Our waggons, which were obliged to take a circuitous route, arrived at last, and we pitched our tent a musket-shot from the kraal, and, after having arranged everything, went to rest, but were soon disturbed; for, about midnight the cattle and horses, which were standing between the waggons, began to start and run, and one of the drivers to shout, on which every one 
ran out of the tent with his gun. About thirty paces from the tent stood a lion, which, on seeing us, walked very deliberately about thirty paces farther, behind a small thornbush, carrying something with him, which I took to be a young ox. We fired more than sixty shots at that bush, without perceiving any movement. The south-east wind blew strong, the sky was clear, and the moon shone very bright, so that we could perceive everything at that distance. After the cattle had been quieted again, and I had looked over everything, I missed the sentry from before the tent, Jan Smit, from Antwerp. We called as loudly as possible, but in vain; nobody answered, from which I concluded that the lion had carried him off. Three or four men then advanced very cautiously to the bush, which stood right opposite the door of the tent, to see if they could discover anything of the man, but returned helter-skelter; for the lion, who was there still, rose up, and began to roar. They found there the musket of the sentry, which was cocked, and also his cap and shoes. We fired again about a hundred shots at the bush, without perceiving anything of the lion, from which we concluded that he was killed, or had run away. This induced the marksman of our company to go and see if he was still there or not, taking with him a firebrand. As soon as he approached the bush, the lion roared terribly, and leapt at him; on which he threw the firebrand at him, and the other people having fired about ten shots at him, he retired directly to his former place behind that bush. The firebrand which he had thrown at the lion had fallen in the midst of the bush, and, favoured by the strong south-east wind, it began to burn with a great flame, so that we could see very clearly into and through it. We continued our firing into it until the night passed away, and the day began to break, when seven men were posted on the farthest waggons to watch him, and to take aim at him if he should come out. At last, before it became quite light, he walked up the 

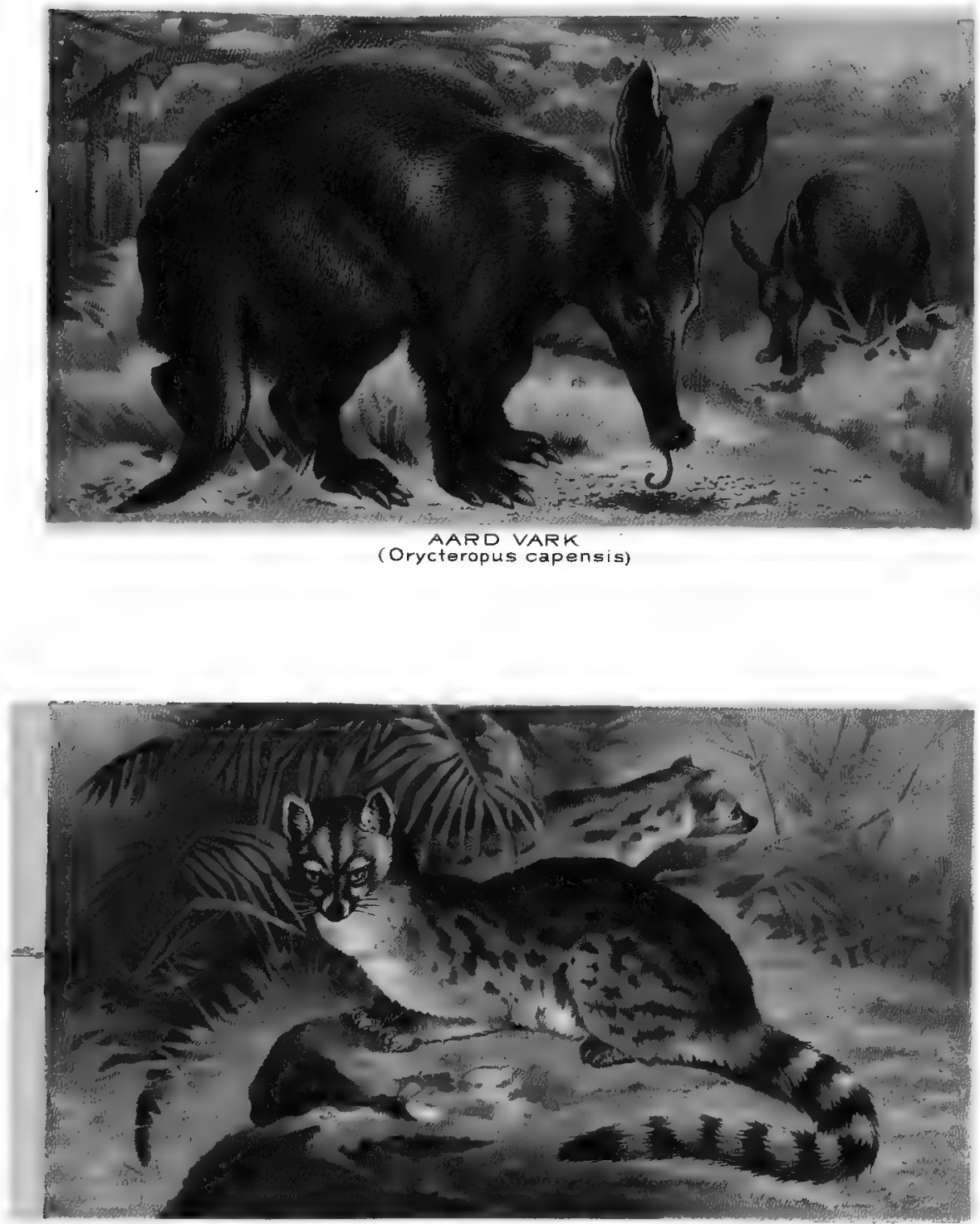

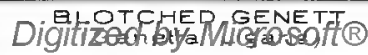


Digitized by Microsofte 
hill, with the man in his mouth, when about forty shots were fired without hitting him, although some were very near. Every time this happened, he turned round towards the tent, and came roaring towards us; and, I am of opinion, that if he had been hit, he would have rushed on the people and the tent. When it became broad daylight, we perceived, by the blood, and a piece of the clothes of the man, that the lion had taken him away." "For the satisfaction of the curious," says Sir William Jardine, "it may be mentioned, that he was followed, and killed in the forenoon, over the mangled remains of the unfortunate sentinel."

A Night Mr. Gordon Cumming gives an even more thrilling

surprise. account of a similar adventure of his experience. He says:- "About three hours after the sun went down, I called to my men to come and take their coffee and supper which was ready for them at my fire; and after supper, three of them returned before their comrades to their own fireside and lay down.... In a few minutes an ox came out by the gate of the kraal and walked round the back of it. Hendrick got up and drove him again and then went back to his fireside and lay down. Hendrick and Ruyter lay on one side of the fire under one blanket and John Stofolus lay on the other.... Suddenly the appalling and murderous voice of an angry bloodthirsty lion, within a few yards of us, burst upon my ear, followed by the shrieking of the Hottentots. Again and again the murderous roar of the attack was repeated. We heard John and Ruyter shriek, 'the Lion! the Lion!...' Next instant John Stofolus rushed into the midst of us almost speechless with fear and terror, and eyes bursting from their sockets, and shrieked out, "the lion! the lion! $\mathrm{He}$ has got Hendrick, he dragged him away from the fire beside me. I struck him with the burning brands upon his head, but he would not let go his hold. Hendrick is dead! O God! Hendrick is dead! Let us take fire and seek him....' It appeared that when the unfortunate Hendrick 
rose to drive in the ox, the lion had watched him to his fireside, and he had scarcely lain down, when the brute sprang upon him and Ruyter (for both lay under one blanket) with his appalling murderous roar, and roaring as he lay, grappled him with his fearful claws and kept biting him on the breast and shoulder, all the while feeling for his neck; having got hold of which, he at once dragged him away backwards round the bush into the dense shade.... The next morning, just as the day began to dawn we heard the lion dragging something up the river side under cover of the bank. We drove the cattle out of the $\mathrm{kraal}$ and then proceeded to inspect the scene of the night's awful tragedy. In the hollow where the lion had lain, consuming his prey, we found one leg of the unfortunate Hendrick, bitten off below the knee, the shoe still on the foot, the grass and bushes were all stained with his blood, and fragments of his pea-coat lay around. Hendrick was by far the best man I had about my waggons... his loss to us all was very serious."

A Iion In the southern part of Africa, where the HotOutwitted. tentots live, lions were very common, and the adventures of the inhabitants, with them very frequent. One evening a Hottentot saw that he was pursued by a lion. He was very much alarmed, and devised the following means of escape. He went to the edge of a precipice, and placed himself a little below it. He then put his cloak and hat on a stick, and elevated them over his head, giving them a gentle motion. The lion came crouching along, and, mistaking the cloak and hat for the man, as the Hottentot intended he should do, he sprang upon them with a swift leap, and, passing over the head of the Hottentot, was plunged headlong down the precipice.

Old Instinets In the "Miscellany of Natural History," from and now which several of these anecdotes are taken there Opportunities. is a story illustrating the way in which old instincts will show themselves in the presence of new 
opportunities. On the evening of the 20th October 1816, a lioness made her escape from a travelling menagerie which was drawn up on the road-side, about seven miles from the town of Salisbury. It was about eight o'clock, and quite dark, and the Exeter mail was passing when the animal suddenly darted forward, and springing at the throat of the off-leader, fastened the talons of her fore-feet on each side of the neck, close to the horse's head, while those of the hind-feet were forced into the chest. In this situation she hung, while the blood streamed from the agonized creature, as if a vein had been opened by a lancet. It may be easily supposed, that the alarm excited by this encounter, was very great. Two inside passengers instantly dashed out of the coach and fled to a house on the roadside. The keeper of the caravan came, and immediately set a large Newfoundland dog on the animal. The lioness, on finding herself seized by the leg, quitted the horse, and turned upon the dog, which the spectators expected would very soon become the victim of her fury; but she was contented with giving him only a slight punishment, and on hearing the voice of her keeper, retired under a neighbouring straw rick, and gently allowed herself to be secured. "This anecdote," says the writer, "is remarkably characteristic, the moment that the animal found herself at liberty, and an object of prey presented itself, all her original propensities, hitherto restrained, were instantly called into action; but no sooner did the voice of her keeper reach her ears, than the force of long habit prevailed, she became calm, and allowed herself to be bound, and led again to her den."

The Tiger. The tiger is one of the most beautiful, but at the same time one of the most rapacious and destructive of the whole animal race. It is found in the warm climates of the East, especially in India and Siam. It so much resembles the cat, as almost to induce us to consider the latter a tiger in miniature. It lurks generally near a fountain, or on the 
brink of a river, to surprise such animals as come to quench their thirst; and like the lion bounds upon its prey, easily making a spring of twenty feet and upwards. When it has killed one animal it often attacks others, swallowing their blood for which it has an insatiable thirst in large draughts; for even when satisfied with food, it is not satiated with slaughter. The tiger is said by some to prefer human flesh to that of any other animal; and it is certain, that it does not, like many other beasts of prey, shun the presence of man, but has been even known on more than one occasion to spring upon a hunting party when seated at their refreshment, and carry off one of the number, rushing through the shrubs into the forest, and devouring the unfortunate victim at its leisure. The strength as well as the agility of this animal is remarkable; it carries off a deer with the greatest ease.

The tiger is ornamented with long streaks across its body. The ground colour is yellow, very deep on the back, but growing lighter towards the belly, where it softens to white, as it does also on the throat and the inside of the legs. The bars which cross the body from the back to the belly are of the most beautiful black, and the skin altogether is so extremely fine and glossy, that it is much esteemed, and sold at a high price in all the eastern countries, especially China. "The colouring of the tiger," says the Rev. J. G. Wood," is a good instance of the manner in which animals are protected by the similarity of their external appearance to the particular locality in which they reside. The stripes on the tiger's skin so exactly assimilate with the long jungle grass amongst which it lives, that it is impossible for unpractised eyes to discern the animal at all, even when a considerable portion of its body is exposed."

Ravages The ravages committed by tigers have often Committed led to the organisation of hunting parties formed by Tigers. with a view to exterminate the more aggressive of the enemy. The following narrative of a tiger excursion 
at Doongal is from the "East India Government Gazette." "There were five tigers killed by the party, besides one bear killed, and another wounded; a wolf, a hyæna, a panther, a leopard, and some immense rock and cobra capella snakes. Among the occurrences during the excursion, some were of a peculiar and pathetic nature. The first happened to a poor Bunnia, or dealer, of the village of Doongal, who had been to the city of Hydrabad, to collect some money, and who was returning, after having gathered together a small sum, when on the way, a little beyond the cantonment of Secunderabad, he saw an armed Pæon seated, and apparently a traveller in the same direction. After mutual inquiries, the Pæon told the Bunnia he was going to the same place; and, as the Bunnia was glad to have somebody to accompany him, he gave him a part of his victuals; and, on their way, they mutually related their histories. The Bunnia innocently mentioned the object of his visit to the city, and the fact of his returning with the money he had collected; this immediately raised the avarice of the Pæon, who decided in his mind to kill the poor Bunnia in a suitable place, and strip him of his money. They proceeded together, with this design in the mind of the Pæon, until they came to a place where the ravages of the tiger were notorious, and he prepared to kill the Bunnia; and while he was struggling with him, and in the act of drawing his sword to slay him, a tiger sprang upon the Pæon, and carried him off, leaving his shield and sword, which the Bunnia carried to Doongal, as trophies of retributive justice in his favour. The next victim was the wife of a Bunjarra. They were resting under a tree, when a tiger sprang up, and seized the woman by the head. The husband, from mere impulse to save his wife, held her by the legs; and a struggle ensued between the tiger pulling her by the head, and the man by the legs, until the issue, which could not be doubted, when the tiger carried off the woman. The man seemed to be rather partial to his wife, and devoted 
himself to revenge her death,-forsook his cattle and property,-resigned them to his brother, and offered his services to be of the tiger-killing party, and strayed about the jungles, until he was heard of no more."

"A camel driver, who had been just married, was bringing home his bride, when a tiger followed, and kept them in view a great part of the road, for an opportunity to seize one of them. The bride having occasion to alight, was immediately pounced upon by the ferocious beast, and he scampered away with her in his mouth. A shepherd was taken by a young tiger, which was followed by the mother, a large tigress, and devoured at a distance of two miles; and a Bunnia, or dealer, from Bolarum, was seized returning from a fair. A woman, with an infant about a year old, was captured by a tiger; and the infant was found by the Puttal, or head of the village, who brought it to his house. Some of the Company's elephants that were going for forage were chased by a tiger, which was kept off by a spearman; and a comical chase of hem was made up to Doongal, the elephants running before the tiger, until they entered the village. It is said the lives lost by these tigers amounted to about three hundred persons in one year, within the range of seven villages; and the destruction of cattle, sheep, and goats, was said to be immense."

An Intrepid Captain Brown in his "Natural History of Hunter. Animals" tells a thrilling story of an adventure of Lieutenant Collet, of the Bombay army, who having heard that a very large tiger had destroyed seven inhabitants of an adjacent village, resolved, with another officer, to attempt the destruction of the monster. Having ordered seven elephants, they went in quest of the animal, which they found sleeping beneath a bush. Roused by the noise of the elephants, he made a furious charge upon them, and Lieutenant Collet's elephant received him on her shoulder, the other six having turned about, and run off, notwithstanding the exertions of 
their riders. The elephant shook off the tiger, and Lieutenant Collet having fired two balls at him, he fell; but, again recovering himself, he made a spring at the lieutenant. Having missed his object, he seized the elephant by the hind leg, and, having received a kick from her, and another ball, he let go his hold, and fell a second time. Supposing that he was now disabled, Collet very rashly dismounted, with the resolution of killing him with his pistols; but the tiger, who had only been crouching to take another spring, flew upon the lieutenant, and caught him in his mouth. The strength and intrepidity of the lieutenant, however, did not forsake him: he immediately fired his pistol into the tiger's body, and, finding that this had no effect, disengaged his arms with all his force, and, directing the other pistol to his heart, he at last destroyed him, after receiving twenty-five severe wounds.

The The Leopard, who is also known as the panther,

Leopard. belongs to Asia and Africa. $\mathrm{He}$ is distinguished by the beauty of his coat which is of a rich fawn colour, graduating to white underneath his belly. It is covered with spots or clusters of marks which resemble the form of a rose. $\mathrm{He}$ is an agile climber and a terror to goats, sheep, monkeys and all lesser animals, but shows no special hostility to man unless attacked or cornered.

The

Like other members of the cat family the Leopard

Loopard's shows remarkable tenacity of life. Whether like Tenacity of the domestic cat he has nine lives or not, he Life. certainly takes a great deal of killing.

The following account is from the pen of an eye-witness quoted from Captain Brown's "Natural History of Animals". - "I was at Jaffna, at the northern extremity of the Island of Ceylon, in the beginning of the year 1819, when, one morning, my servant called me an hour or two before my usual time, with 'Master, master! people sent for master's dogs-tiger in the town!' There are no real tigers in Ceylon; 
but leopards or panthers are always called so, and by ourselves as well as by the natives. This turned out to be a panther. My gun chanced not to be put together; and, while my servant was doing it, the collector and two medical men, who had recently arrived, in consequence of the cholera morbus having just then reached Ceylon from the Continent, came to my door, the former armed with a fowling-piece, and the two latter with remarkably blunt hog-spears. They insisted upon setting off, without waiting for my gun,- - a proceeding not much to my taste. The tiger ( $I$ must continue to call him so) had taken refuge in a hut, the roof of which, like those of Ceylon huts in general, spread to the ground like an umbrella; the only aperture into it was a small door, about four feet high. The collector wanted to get the tiger out at once. I begged to wait for my gun; but no-the fowling-piece, (loaded with ball, of course,) and the two hogspears, were quite enough. I got a hedge-stake, and awaited my fate, from very shame. At this moment, to my great delight, there arrived from the fort an English officer, two artillery-men, and a Malay captain; and a pretty figure we should have cut without them, as the event will show. I was now quite ready to attack, and my gun came a minute afterwards. The whole scene which follows took place within an enclosure, about twenty feet square, formed, on three sides, by a strong fence of palmyra leaves, and on the fourth by the hut. At the door of this, the two artillery-men planted themselves: and the Malay captain got at the top, to frighten the tiger out, by worrying it-an easy operation, as the huts there are covered with cocoa-nut leaves. One of the artillerymen wanted to go in to the tiger, but we would not suffer it. At last the beast sprang. This man received him on his bayonet, which he thrust apparently down his throat, firing his piece at the same moment. The bayonet broke off short, leaving less than three inches on the musket; the rest remained in the animal, but was invisible to us. The shot probably 
went through his cheek, for it certainly did not seriously injure him, as he instantly rose upon his legs, with a loud roar, and placed his paws upon the soldier's breast. At this moment, the animal appeared to me to about reach the centre of the man's face; but I had scarcely time to observe this, when the tiger, stooping his head, seized the soldier's arm in his mouth, turned him half round staggering, threw him over on his back, and fell upon him. Our dread now was, that, if we fired upon the tiger, we might kill the man. For a moment, there was a pause, when his comrade attacked -the beast exactly in the same manner as the gallant fellow himself had done. He struck his bayonet into his head; the tiger rose at him-he fired; and this time the ball took effect, and in the head. The animal staggered backwards, and we all poured in our fire. He still kicked and writhed; when the gentlemen with the hog-spears advanced, and fixed him, while he was finished by some natives beating him on the head with hedge-stakes. The brave artilleryman was, after all, but slightly hurt: He claimed the skin, which was very cheerfully given to him. There was, however, a cry among the natives, that the head should be cut off: it was; and, in so doing, the knife came directly across the bayonet. The animal measured little less than four feet, from the root of the tail to the muzzle. There was no tradition of a tiger having been in Jaffna before. Indeed, this one must have either come a distance of almost twenty miles, or have swam across an arm of the sea nearly two miles in breadth; for Jaffna stands on a peninsula, on which there is no jungle of any magnitude."

Hunters Captain Brown gives a thrilling story of an

Hunted. adventure which befell two Boers in South Africa in 1822 . They were returning from a hunting excursion, when they unexpectedly fell in with a leopard in a mountain ravine, and immediately gave chase to him. The animal at first endeavoured to escape, by clambering up a 
precipice, but, being hotly pressed, and slightly wounded by a musket-ball, he turned upon his pursuers, with that frantic ferocity, which, on such emergencies, he frequently displays, and, springing upon the man who had fired at him, tore him from his horse to the ground, biting him at the same time very severely on the shoulder, and tearing his face and arms with his claws. The other hunter, seeing the danger of his comrade, sprang from his horse, and attempted to shoot the leopard through the head; but, whether owing to trepidation, or the fear of wounding his friend, or the sudden motions of the animal, he unfortunately missed his aim. The leopard, abandoning his prostrate enemy darted with redoubled fury upon this second antagonist; and so fierce and sudden was his onset, that before the Boer could stab him with his hunting-knife, he had struck him in the face with his claws, and torn the scalp over his forehead. In this frightful condition, the hunter grappled with the raging beast, and, struggling for life, they rolled together down a steep declivity. All this passed so rapidly that the other man had scarcely time to recover from the confusion into which his feline foe had thrown him, to seize his gun and rush forward to aid his comrade, when he beheld them rolling together down the steep bank, in mortal conflict. In a few moments he was at the bottom with them, but too late to save the life of his friend, who had so gallantly defended him. The leopard had torn open the jugular vein, and so dreadfully mangled the throat of the unfortunate man, that his death was inevitable; and his comrade had only the melancholy satisfaction of completing the destruction of the savage beast, which was already much exhausted by several deep wounds it had received in the breast, from the desperate knife of the expiring huntsman."

The Jaguar. The Jaguar, otherwise known as the American Leopard, belongs to the forests of South America, and has many points of difference from as well as some of similarity with 


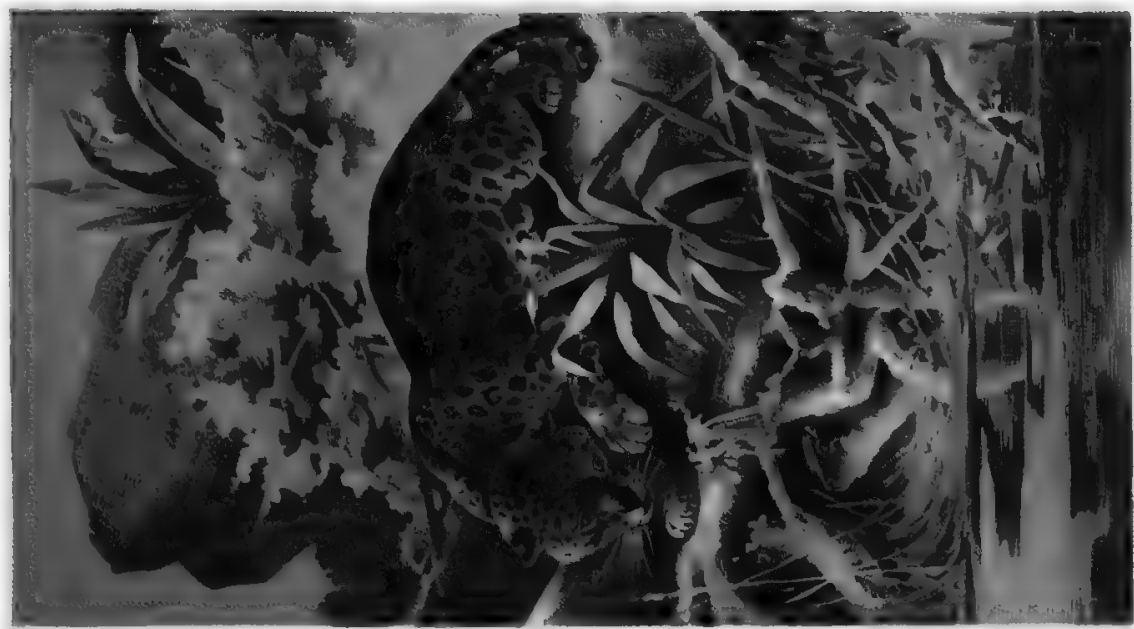

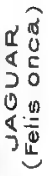

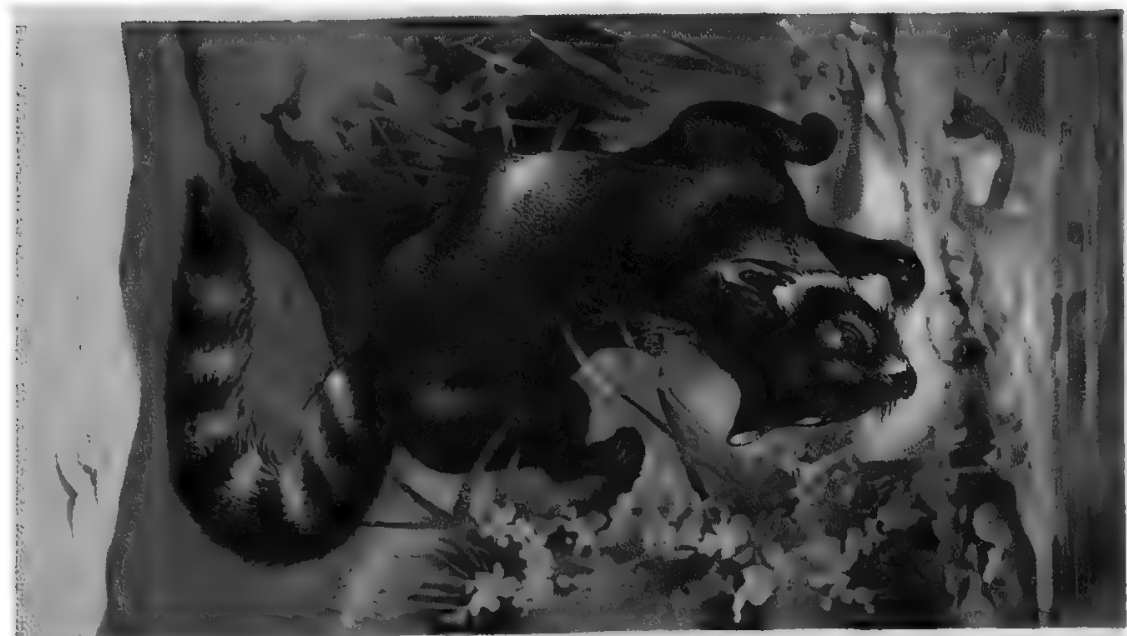

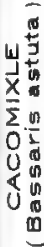


Digitized by Microsofte 
the Leopard of Asia. Though ferocious in his wild state, he is amenable to civilizing influences and becomes mild and tame in captivity. $\mathrm{He}$ is an excellent swimmer and an expert climber, ascending to the tops of high branchless trees by fixing his claws in the trunks. It is said that he can hunt in the trees almost as well as he can upon the ground, and that hence he becomes a formidable enemy to the monkeys. $\mathrm{He}$ is also a clever fisherman, his method being that of dropping saliva on to the surface of the water, and upon the approach of a fish, by a dexterous stroke of his paw knocking it out of the water on to the bank. D'Azara, says: " $\mathrm{He}$ is a very ferocious animal causing great destruction among horses and asses. $\mathrm{He}$ is extremely fond of eggs, and goes to the shores frequented by turtles, and digs their eggs out of the sand."

The Strength The strength of the Jaguar is very great, and of the Jaguar. as he can climb, swim, and leap a great distance, he is almost equally formidable in three elements. He is said to attack the alligator and to banquet with evident relish off his victim. D'Azara says that on one occasion he found a Jaguar feasting upon a horse which it had killed. The Jaguar fled at his approach, whereupon he had the body of the horse dragged to within a musket shot of a tree in which he purposed watching for the Jaguar's return. While temporarily absent he left a man to keep watch, and while he was away the jaguar reappeared from the opposite side of a river which was both deep and broad. Having crossed the river the animal approached, and seizing the body of the horse with his teeth dragged it some sixty paces to the water side, plunged in with it, swam across the river, pulled it out upon the other side, and carried it into a neighbouring wood.

A Night of Mrs. Bowdich tells a story of two early settlers Horror. in the Western States of America, a man and his wife, who closed their wooden hut, and went to pay a visit at a distance, leaving a freshly-killed piece of venison 
hanging inside. "The gable end of this house was not boarded up as high as the roof, but a large aperture was left for light and air. By taking an enormous leap, a hungry jaguar, attracted by the smell of the venison, had entered the hut and devoured part of it. $\mathrm{He}$ was disturbed by the return of the owners, and took his departure. The venison was removed. The husband went away the night after to a distance, and left his wife alone in the hut. She had not been long in bed before she heard the jaguar leap in at the open gable. There was no door between her room and that in which he had entered, and she knew not how to protect herself. She, however, screamed as loudly as she could, and made all the violent noises she could think of, which served to frighten him away at that time; but she knew he would come again, and she must be prepared for him. She tried to make a large fire, but the wood was expended. She thought of rolling herself up in the bedclothes, but these would be torn off. The idea of getting under the low bedstead suggested. itself, but she felt sure a paw would be stretched forth which would drag her out. Her husband had taken all their firearms. At last, as she heard the jaguar scrambling up the end of the house, in despair she got into a large store chest, the lid of which closed with a spring. Scarcely was she within it, and had dragged the lid down, inserting her fingers between it and the side of the chest, when the jaguar discovered where she was. He smelt round the chest, tried to get his head in through the crack, but fortunately he could not raise the lid. $\mathrm{He}$ found her fingers and began to lick them; she felt them bleed, but did not dare to move them for fear she should be suffocated. At length the jaguar leaped on to the lid, and his weight pressing down the lid, fractured her fingers. Still she could not move. He smelt round again, he pulled, he leaped on and off, till at last getting tired of his vain efforts, he went away. The poor woman lay there 
till daybreak, and then only feeling safe from her enemy, she went as fast as her strength would let her to her nearest neighbour's a distance of two miles, where she procured help for her wounded fingers, which were long in getting well. On his return, her husband found a male and female jaguar with their cubs, in the forest close by, and all were destroyed."

The Puma. The Puma, or American lion, is known by several names. It is sometimes called a panther, or colloquially a "painter", and sometimes a cougar. It resembles the lioness somewhat in appearance, especially about the head, though it is smaller and less powerful. Its length varies from four feet to four feet and a half, and its colour is that of the fox, graduating in parts to white. Like the lion it inhabits plains rather than forests;-in the marshy districts, and on the borders of rivers in the south, and in the swamps and prairies of the northern districts. It lives on such wild and domestic animals as come within its reach, lying at full length upan the lower branches of trees, and dropping upon its victims as they pass beneath. Deer and cattle of all kinds it attacks, and, not content with killing enough for immediate purposes, destroys large numbers, sucking small quantities of blood from each. According to Sir William Jardine it is exceedingly destructive among sheep and has been known to kill fifty in one night. The Puma is, however, easily tamed and becomes very docile under kindly treatment. Edward Kean kept a tame one which followed him about like a dog and was as playful as a kitten.

The Puma's "Molina and D'Azara say," says Sir William

Ferocity. Jardine, "that the puma will flee from men, and that its timidity renders its pursuit generally free from danger." The following incident given by Sir William Jardine and at greater length by Captain Brown, shows that this is not always the case. According to these accounts, two hunters visited the Katskills in pursuit of game, each armed 
with a gun and" accompanied by a dog. They agreed to follow contrary directions round the base of a hill, and to join each other immediately upon hearing the report of a gun. Shortly after parting, one of the friends heard the gun of his comrade and hastening to his assistance came first upon the body of his friend's dog, torn and lacerated; proceeding further, his attention was attracted by the growl of a wild animal, and looking up, he discovered a large puma crouching over the body of his friend, upon the branch of a tree. The animal glared at him, and he, knowing the rapidity of the Puma's movements, immediately raised his gun and fired, whereupon the puma rolled over on to the ground with his prey. The dog flew at the infuriated beast, but one blow from the puma's paw silenced him for ever. Seeing that his comrade was dead the hunter left the scene in search of assistance, upon securing which, he returned to find the puma dead, beside the two dogs and the hunter whom he had killed.

Animals and Captain Head, in his "Journey Across the PamMon. pas" says:- "The fear which all wild animals in America have of man is very singularly seen in the Pampas. I often rode towards the ostriches and zamas, crouching under the opposite side of my horse's neck; but I always found that, although they would allow my loose horse to approach them, they, even when young, ran from me, though little of my figure was visible; and when I saw them all enjoying themselves in such full liberty, it was at first not pleasing to observe that one's appearance was everywhere a signal to them that they should fly from their enemy. Yet it is by this fear 'that man hath dominion over the beasts of the field,' and there is no animal in South America that does not acknowledge this instinctive feeling. As a singular proof of the above, and of the difference between the wild beasts of America and of the old world, I will venture to relate a circumstance which a man sincerely assured me had happened 
to him in South America:- He was trying to shoot some wild ducks, and, in order to approach them unperceived, he put the corner of his poncho (which is a sort of long narrow blanket) over his head, and crawling along the ground upon his hands and knees, the poncho not only covered his body, but trailed along the ground behind him. As he was thus creeping by a large bush of reeds, he heard a loud, sudden noise, between a bark and a roar: he felt something heavy strike his feet, and, instantly jumping up, he saw, to his astonishment, a large puma actually standing on his poncho; and, perhaps, the animal was equally astonished to find himself in the immediate presence of so athletic a man. The man told me he was unwilling to fire, as his gun was loaded with very small shot; and he therefore remained motionless, the puma standing on his poncho for many seconds; at last the creature turned his head, and walking very slowly away about ten yards, he stopped, and turned again: the man still maintained his ground, upon which the puma tacitly acknowledged his supremacy, and walked off."

The Ocelot. The Ocelot is a native of South America and one of the most beautiful of the Cat family. It is smaller than the Leopard, attaining to about three feet in length, and eighteen inches in height. Its colour is grey, tinged with fawn and the body and legs are covered with longitudinal chainlike stripes broken into patches of some inches. Its habits are like those of its near relations, the Leopard and the Jaguar, though its appetite for blood makes it perhaps even more destructive. It will suck blood with the greatest avidity and frequently leave a carcase otherwise untouched in order to pursue other animals for the sake of more blood. When tame the Ocelot is remarkably playful, climbing up the legs and nestling in the arms of its benefactors. It is apt to be dangerous in a poultry yard but will keep good friends with a house dog, and play, somewhat roughly, perhaps, but without malice, with children. 
The Clouded; This animal belongs to Sumatra where it lives Tiger. upon the forest birds. Like the Ocelot it is exceedingly playful when tame, seeking the notice and returning the caresses of all who encourage it.

The Serval. "The Serval," says Captain Brown, "is somewhat larger than the ordinary wild cat. Its general colour is a pale fulvous yellow. It resides on trees, where it makes a bed, and breeds its young. It seldom appears on the ground, living principally on birds, squirrels, and small animals; it is extremely agile, and leaps, with great rapidity, from one branch to another. The serval never assaults man, but rather endeavours to avoid him; if, however, it is compelled to attack, it darts furiously on its antagonist, and bites and tears, like the rest of the cat kind."

The Common The common wild cat is one of the few wild

wild Cat. animals still to be found in the British Isles. Up till recent years these cats were observed among the woody mountainous districts of Cumberland and Westmoreland and in the wild parts of Scotland and Ireland, though as the land is brought more and more under cultivation they decrease in numbers, failing suitable asylum. They abound in the forests of Germany and Russia, where they live in the hollows of trees and caves of rocks, and feed on birds, squirrels, hares and rabbits, and will even attack young lambs and fawns. The wild cat is not to be confused with the domestic cat which has relapsed into a wild state. "In the form and shape of the tail," says Sir William Jardine, "this animal somewhat resembles the Lynx. The fur is very thick, woolly and long. The general colour is a greyish yellow, in some specimens inclining much to a shade of bluish grey." - "They spring," says Mrs. Bowdich, "furiously upon whoever approaches, and utter unearthly cries. Mr. St. John, when walking up to his knees in heather over broken ground, came suddenly upon a wild cat. She rushed out between his legs, every hair standing up. He cut a good-sized stick; and three Skye 
terriers gave chase till she took refuge in a corner, spitting and growling. On trying to dislodge her, she flew at $\mathrm{Mr}$. St. John's face, over the dogs' heads; but he struck her while in the air, and she fell among the dogs, who soon despatched her, even though it has been said that a wild cat has twelve instead of nine lives. If one of these animals is taken, those in the neighbourhood are sure to be also secured, as they will all, after the manner of foxes, assemble round the body of their relative."

The Domestic The origin of the domestic cat is difficult to Cat. determine. Cats were numerous in Egypt from an early date, and are said to be native to Syria. According to Professor Rolleston the cat was not domesticated anywhere, except in Egypt, before the Christian Era. Few animals are more familiar to the general reader, and few therefore, need less description. The "Tabby" is perhaps the commonest, though black, white, and tortoise-shell varieties abound. The Angora or Angola cat, the Persian cat, and the Manx cat, which latter is deficient in the useful and ornamental embellishment of a tail, are also well known.

Cat There are many superstitions concerning the Buperstitions. cat, the black variety coming in for the larger share of popular suspicion. To steal one and bury it alive was at one time regarded as a specific against cattle desease in the Irish Highlands, while, according to Captain Brown, it was the practice for families in Scotland to tie up their cats on Hallowe'en to prevent their use for equestrian purposes by witches during the night. "They have always been regarded as attendants upon witches," says Mrs. Bowdich, "and witches themselves have been said to borrow their shapes when on their mysterious expeditions. I was once told that Lord Cochrane was accompanied by a favourite black cat in a cruise through the northern seas. The weather had been most unpropitious; no day had passed without some untoward circumstance; and the sailors were not slow in attributing the 
whole to the influence of the black cat on board. This came to Lord Cochrane's ears, and knowing that any attempt to reason his men out of so absurd a notion was perfectly useless, he offered to sacrifice this object of his regard, and have her thrown overboard. This, however, far from-creating any satisfaction, only alarmed the men still more. They were sure that the tempests she would then raise would be much worse than any they had yet encountered; and they implored his lordship to let her remain unmolested. "There was no help, and they could only hope, if she were not affronted, they might at the end of their time reach England in safety." "

The Cat as "The cat," says the Rev. J. G. Wood, "is fami-

a Hunter. liarly known to us as a persevering mouse-hunter. So strong, indeed, is the passion for hunting in the breast of the cat, that she sometimes disdains mice, 'and such small deer,' and trespasses on warrens or preserves. A large tabby cat, residing at no great distance from White Horse Vale, was accustomed to go out poaching in the preserves of a neighbouring nobleman, and so expert was she at this illegal sport that she constantly returned bearing in her mouth a leveret or a partridge, which she insisted on presenting to her mistress, who in vain endeavoured to check her marauding propensities. These exploits, however, brought their own punishment; for one day, when in the act of seizing a leveret, she found herself caught in a vermin trap, which deprived her of one of her hind legs. This misfortune did not damp her enthusiasm for hunting, as, although the loss of a leg prevented her from chasing hares, and suchlike animals, she would still bring in an occasional rat."

The Cat and "A cat, which had a numerous litter of kittens," her Young. says Captain Brown, "one sunny day encouraged her little ones to frolic in the vernal beams of noon, about the stable door, where she was domiciled. While she was 
joining them in a thousand tricks and gambols, a large hawk, who was sailing above the barn-yard, in a moment darted upon one of the kittens, and would have as quickly borne it off, but for the courageous mother, who, seeing the danger of her offspring, sprang on the common enemy, who, to defend itself, let fall the prize. The battle presently became severe to both parties. The hawk, by the power of his wings, the sharpness of his talons, and the strength of his beak, had for a while the advantage, cruelly lacerating the poor cat, and had actually deprived her of one eye in the confict; but puss, no way daunted at the accident, strove, with all her cunning and agility, for her kittens, till she had broken the wing of her adversary. In this state, she got him more within the power of her claws, and availing herself of this advantage, by an instantaneous exertion, she laid the hawk motionless beneath her feet; and, as if exulting in the victory, tore the head off the vanquished tyrant. This accomplished, disregarding the loss of her eye, she ran to the bleeding kitten, licked the wounds made by the hawk's talons in its tender sides, and purred whilst she caressed her liberated offspring."

The Cat as The female cat seems to be in a special sense Foster a born mother. She is assiduous in the care of Mother. her own young and singularly ready to extend the benefits of motherhood even to alien offspring. Instances are on record in which cats have reared squirrels, dogs, leverets, rats, ducks, chickens, and even small birds. These have usually occurred at times when the cats have been deprived of their own young. Mr. T. Foggitt says: "A cat belonging to the Albert Dock Warehouse, Liverpool, gave birth to six kittens. It was deemed necessary to destroy four of them, and they were accordingly drowned. The remaining two were placed, along with their mother, in some loose cotton, collected for the purpose in a box, in one of the warehouse rooms. On removing the box a few mornings after, to give 
puss her usual breakfast, great curiosity was excited on seeing a third added to the number; and the astonishment was still greater when the third was discovered to be a young rat which the cat had taken from its nest in the night-time, and brought home as a companion to the kittens she was then nursing. The young rat was very lively, and was treated by the cat with the same attention and care as if it were one of her own offspring."

The Cat as a The distances that cats will travel, finding

Traveller. their way with unerring instinct many miles across country of which there seems no reason to suppose them to have had previous knowledge is very remarkable. Mrs. Bowdich records the case of a cat who disliking her new home, returned to her old one, in doing which, she had to cross two rivers, one of them about eighty feet broad and two feet and a half deep, running strong; the other wider and more rapid, but less deep. Cats are said to have found their way from Edinburgh to Glasgow, and one to the writer's knowledge returned from Dover to Canterbury after being carried from thence by rail. Captain Brown gives the following remarkable instance. In June, I 825, a farmer, residing in the neighbourhood of Ross, sent a load of grain to Gloucester, a distance of about sixteen miles. The waggoners loaded in the evening, and started early in the morning. On unloading at Gloucester, a favourite cat, belonging to the farmer, was found among the sacks, with two kittens of very recent birth. The waggoner very humanely placed puss and her young in a hay-loft, where he expected they would remain in safety, until he should be ready to depart for home. On his return to the loft shortly afterwards, neither cat nor kittens were to be found, and he reluctantly left town without them. Next morning the cat entered the kitchen of her master's house with one kitten in her mouth. It was dead; but she placed it before the fire, and without seeking food, o indulging, for a moment, in the genial warmth of stic her dome hearth, 
disappeared again. In a short time she returned with the other kitten, laid it down by the first, stretched herself beside them, and instantly expired! The poor creature could have carried but one at a time, and, consequently, must have travelled three times over the whole line of her journey, and performed forty-eight miles in less than twelve hours.

The cat as The favourite food of the cat is fish, which Sportsman. curiously enough inhabits an element to which the cat has a great aversion. There are, however, numerous instances on record of cats which have overcome their natural antipathy to water in order to gratify their natural taste for fish. An extraordinary case of this kind is recorded in the Plymouth Journal, June, 1828:- " There is now at the battery on the Devil's Point, a cat, which is an expert catcher of the finny tribe, being in the constant habit of diving into the sea, and bringing up the fish alive in her mouth, and depositing them in the guard-room, for the use of the soldiers. She is now seven years old, and has long been a useful caterer. It is supposed that her pursuit of the water-rats first taught her to venture into the water, to which it is well known puss has a natural aversion. She is as fond of the water as a Newfoundland dog, and takes her regular peregrinations along the rocks at its edge, looking out for her prey, ready to dive for them at a moment's notice."

Mr. Beverley R. Morris says: "When living in Worcester many years ago, I remember frequently seeing the cat of a near neighbour of ours bring fish, mostly eels, into the house, which it used to catch in a pond not far off. This was an almost everyday occurrence."

The Cat's Many remarkable illustrations might be given Intelligence. of the sagacity and intelligence of the cat. A lady had for many years been the possessor of a cat and a canary bird, who became the closest friends, never bearing any lengthy separation from each other, and spending their whole time in each other's society. One summer day the 
lady was sitting working in her drawing-room, and the cat and bird were a short distance off. Suddenly, without a moment's deliberation, the cat, to the great astonishment of the lady, uttered a loud growl, and then, seizing her little playmate in her mouth, darted off with it to a place of safety. A strange cat had entered the room and the friendly one had adopted this plan of saving the bird from the enemy. A still more remarkable illustration of the intelligence of a cat is given by De la Croix as follows: "I once saw," says he, "a lecturer upon experimental philosophy place a cat under the glass receiver of an air-pump, for the purpose of demonstrating that very certain fact, that life cannot be supported without air and respiration. The lecturer had already made several strokes with the piston, in order to exhaust the receiver of its air, when the animal, who began to feel herself very uncomfortable in the rarefied atmosphere, was fortunate enough to discover the source from which her uneasiness proceeded. She placed her paw upon the hole through which the air escaped, and thus prevented any more from passing out of the receiver. All the exertions of the philosopher were now unavailing; in vain he drew the piston; the cat's paw effectually prevented its operation. Hoping to effect his purpose, he let air again into the receiver, which, as soon as the cat perceived, she withdrew her paw from the aperture; but whenever he attempted to exhaust the receiver, she applied her paw as before. All the spectators clapped their hands in admiration of the wonderful sagacity of the animal, and the lecturer found himself under the necessity of liberating her, and substituting in her place another, that possessed less penetration, and enabled him to exhibit the cruel experiment."

The Lynx. The several species of the Lynx belong to the genus Lyncus, the principle varieties of which are the Canada Lynx, and the European Lynx. The Lynx has short legs, and is generally about the size of a fox, attaining often to three feet in length. It preys upon small quadrupeds and 


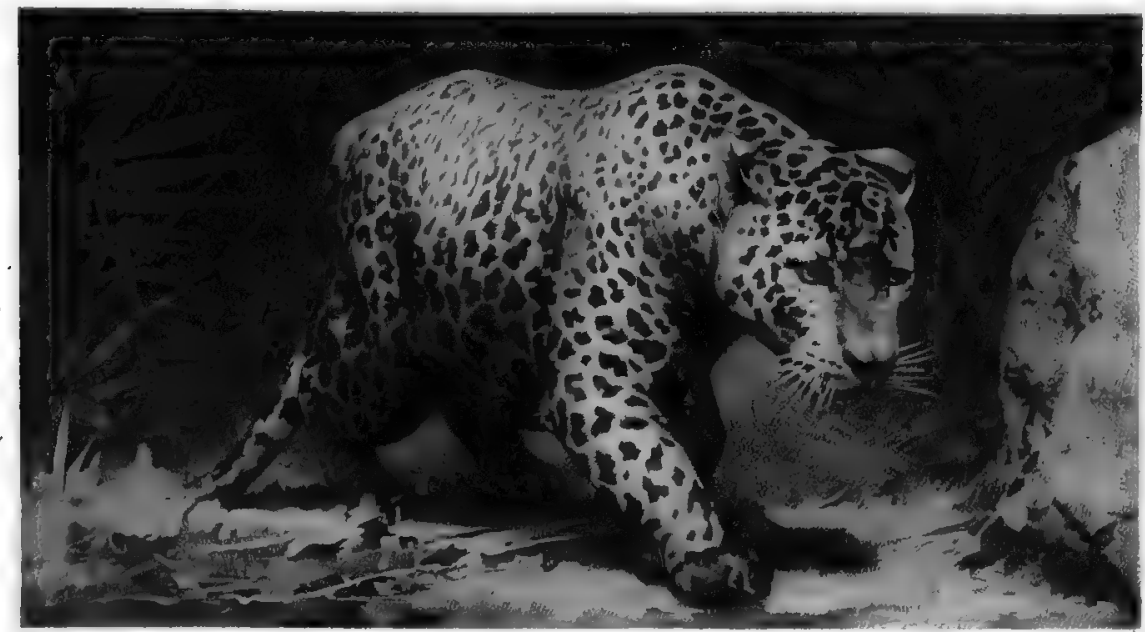

LEOPARD

(Felis pardus)

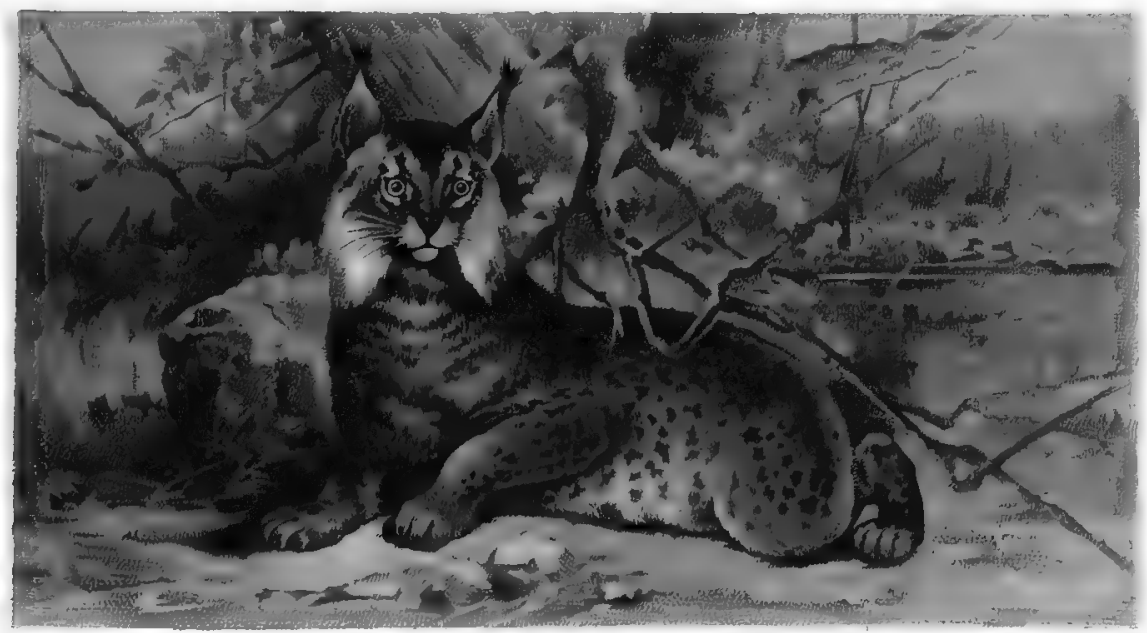

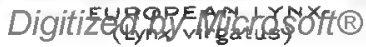


Digitized by Microsofte 
birds, in the pursuit of which it is an expert climber. The Canada Lynx preys largely upon the American hare, which it is well qualified to hunt. The Lynx is distinguished by a peculiar gait, for unlike other animals, it bounds with, and alights upon, all four feet at once. The ears are erect, and tipped with a long pencil of black hair. The fur which is long and thick is of a pale grey colour, with a reddish tinge, marked with dusky spots on the upper part of the body. The under parts are white. The European Lynx feeds upon small animals and birds. The fur of the lynx is valuable, on account of its great softness and warmth, and is in consequence an extensive article of commerce. It inhabits the northern parts of Europe, Asia, and America; and prefers cold or temperate climates, differing in this respect from most of the cat tribe. The Chetah. The Chetah or Hunting Leopard is the one species of the genus Cynœlurus. It is a handsome animal and capable of considerable training. According to Mr. Benet's description it is "intermediate in size between the leopard and the hound, more slender in its body, more elevated in its legs, and less flattened on the fore part of its head than the leopard, while deficient in the peculiarly graceful and lengthened form, both of head and body, which characterizes the hound." "The ground colour of the Chetah is a bright yellowish fawn above, and nearly pure white beneath; covered above, and on the sides, by innumerable closely approximating spots, from half an inch to an inch in diameter, which are intensely black, and do not, as in the leopard and other spotted cats, form roses with a lighter centre, but are full and complete." The Chetah is found in India and Africa but it is only in India that it is trained for hunting purposes. Sir William Jardine says: "the employment of the hunting leopard may be compared to the sport of falconry. The natural instinct teaches them to pursue the game, the reward of a portion of it, or of the blood, induces them to give it up, and again subject themselves to their master." 
The Chetah The practice of employing animals to hunt as a animals is of very early origin, and the docility Huntsman. of the Chetah early marked him out as a suitable ally in the chase. Chetahs are so gentle that they can be led about in a leash like greyhounds. The following description of a hunt is from "The Naturalist's Library". "Just before we reached our ground, the shuter suwars (camel courier), who always moved on our flanks in search of game, reported a herd of antelopes, about a mile out of the line of march, and the Chetahs being at hand, we went in pursuit of them. The leopards are each accommodated with a flattopped cart, without sides, drawn by two bullocks, and each animal has two attendants. They are loosely bound by a collar and rope to the back of the vehicle, and are also held by the keeper by a strap round the loins. A leathern hood covers the eyes. On entering from a cotton field, we came in sight of four antelopes, and my driver managed to get within a hundred yards of them before they took alarm. The Chetah was quickly unhooded and loosed from his bonds; and, as soon as he viewed the deer, he dropped quietly off the cart on the opposite side to that on which they stood, and approached them at a slow crouching canter, masking himself by every bush, and inequality, which lay in his way. As soon, however, as the deer began to show alarm, he quickened his pace and was in the midst of them in a few bounds. He singled out a doe, and ran it close for about 200 yards, when he reached it with a blow of his paw, rolled it over, and in an instant was sucking the life blood from its throat." "As soon as the deer is pulled," says the same account, "a keeper runs up, hoods the Chetah, cuts the victim's throat, and securing some of the blood in a wooden ladle, thrusts it under the leopard's nose. The antelope is then dragged away and placed in a receptacle under the hatchery, while the Chetah is rewarded with a leg for his pains." 
The Civits. The family Viverridæ includes a large number of species of small carnivorous animals of which the Civits and the Ichneumons are the best known. They belong chiefly to Africa and South Asia, but some are found in the south of Europe. The African Civit hails from Gaboon and Abyssinia and the Asiatic variety from Bengal, Nepaul, China and Formosa. It is from these animals that we get the fatty substance, used in perfumery and known as civit. Of this Mr. Piesse says: "In is pure state, civit has to nearly all persons a most disgusting odour, but when diluted to an infinitesimal portion its perfume its agreeable. The Genet, and the Paradoxure are other genera of this family."

The Ichnoumon. The Ichneumon numbers some fifteen genera, and sixty species. The best known of these is the grey Ichneumon which comes from India or adjacent countries. Naturally savage it soon becomes tame under kindly treatment. It seems to have a natural enmity towards serpents, which it attacks and destroys. The Mahrattas say that it neutralizes the effects of snake bites by eating the root of the monguswail. Captain Brown records an experiment in which the ichneumon was placed in a room with a poisonous serpent which it tried to avoid. On the two being removed to the open air, the ichneumon is said to have immediately darted at the serpent and destroyed it, afterwards retiring to the wood and eating a portion of the plant said to be an antidote to the serpent's venom. The Ichneumon is about the size of the domestic cat and of a dark silver grey colour. The Egyptian Ichneumon much resembles the cat in its habits and manners and is so deadly a foe to reptiles and vermin, that it is domesticated with a view to their destruction. It is remarkably quick in its movements, darting with unerring aim at the head of the reptile it attacks. It displays also the cat's patience in watching for its prey. It has a great liking for crocodile's eggs and with 
remarkable instinct unearths them from the banks of rivers where they have been deposited.

Dormant Though perfectly tame in captivity, the natural Instinct. instincts of the ichneumon are only dormant, as the following illustration will show. M. d'Obsonville says, in his "Essay on the Nature of Various Animals", "I had an ichneumon very. young, which I brought up. I fed it at first with milk, and afterwards with baked meat, mixed with rice. It soon became even tamer than a cat; for it came when called, and followed me, though at liberty, into the country. One day I brought to him a small water serpent alive, being desirous to know how far his instinct would carry him, against a being with which he was hitherto totally unacquainted. His first emotion seemed to be astonishment, mixed with anger: for his hair became erect; but in an instant after, he slipped behind the reptile, and, with remarkable swiftness and agility, leaped upon its head, seized it, and crushed it between his teeth. This essay, and new aliment, seemed to have awakened in him his innate and destructive voracity, which, till then, had given way to the gentleness he had acquired from his education. I had about my house several curious kinds of fowls, among which he had been brought up, and which, till then, he had suffered to go and come unmolested and unregarded; but, a few days after, when he found himself alone, he strangled them every one, eat a little, and, as it appeared, drank the blood of two."

The Aard The Aard Wolf of South Africa, is the sole Wolf. genus and species of the Protelidæ tamily. It much resembles the hyæna in appearance and habit, and feeds on carrion and white ants.

The Hyюna. The Hyæna, though long treated as a member of the dog family, is now separately classified as the Hyænidæ, a family of one genus and three species, all of which are found in Africa. The Hyæna is also found in Egypt, Arabia, Persia and other parts of Asia. He has 
immensely powerful teeth with which he can crush the bones of his victims, apparently eating bones and flesh with impunity. $\mathrm{He}$ is nocturnal in his habits, living in caves and hollows in the day time and prowling about at night in search of prey. Speaking of the Barbary hyæna Bruce says:- " $\mathrm{He}$ seems to be stupid or senseless in the day, or at the appearance of strong light, unless when pursued by hunters. I have locked up a goat, a kid, and a lamb, with him all day when he was fasting, and found them in the evening alive and unhurt." The principle varieties are the striped Hyæna, and the spotted Hyæna. Bruce speaking of the former says, "he is brutish, indolent, slovenly and impudent and seems to possess much the manners of the wolf. His courage appears to proceed from an insatiable appetite, and has nothing of the brave or generous in it, and he dies oftener flying than fighting." The cry of the hyæna, sometimes called a laugh, begins with a moan and ends with a demoniacal shriek which has been variously described by travellers but which all agree in calling hideous and disgusting. In size he resembles a large mastiff, but the formation of his neck and jaws give him a power far beyond that of other animals of his size. Whatever fear he may have of man, he has none of other animals and will even face the lion. Bruce speaks of his special liking for the flesh of the dog and of the dog's reluctance to face him. "My greyhounds, accustomed to fasten upon the wild boar, would not venture to engage with him. On the contrary, there was not a journey I made that he did not kill several of my greyhounds, and once or twice robbed me of my whole stock: he would seek and seize them in the servants' tents where they were tied, and endeavour to carry them away before the very people that were guarding them." His coat is covered with long coarse hairs of a dirty grey colour, which form a mane the length of his back, his sides being striped or spotted, according to the species. The hyæna for all his repulsiveness serves a useful 
purpose, as a scavenger, devouring all the offal which comes in its way, including the dead of his own species which no other animal will touch. The hyæna can be tamed and taught to follow its master and to hunt other animals.

The striped Bruce tells the following story of the impudence

Hyæna. of the striped hyæna. "One night in Maitsha, being very intent on observation, I heard something pass behind me towards the bed, but upon looking round could perceive nothing. Having finished what I was then about, I went out of my tent, resolving directly to return, which I immediately did, when I perceived large blue eyes glaring at me in the dark. I called upon my servant with a light; and there was the hyæna standing nigh the head of the bed, with two or three large bunches of candles in his mouth. To have fired at him, I was in danger of breaking my quadrant or other furniture; and he seemed, by keeping the candles steadily in his mouth, to wish for no other prey at that time. As his mouth was full, and he had no claws to tear with, I was not afraid of him, but with a pike struck him as near the heart as I could judge. It was not till then he showed any sign of fierceness; but, upon feeling his wound, he let drop the candles, and endeavoured to run up the shaft of the spear to arrive at me; so that, in self-defence, I was obliged to draw out a pistol from my girdle and shoot him, and nearly at the same time my servant cleft his skull with a battle-axe. In a word, the hyæna was the plague of our lives, the terror of our night-walks, the destruction of our mules and asses, which above all others are his favourite food."

The spotted The spotted hyæna belongs to South Africa Hyøna. and seems to possess more daring than his cousin of Abyssinia, and to show a greater preference for human food. According to Mr. Stepstone, the Mambookies build their houses in the form of a beehive from eighteen to twenty feet in diameter, placing a raised platform at the back and leaving the front-area for the accommodation of the calves 
at night. Thus the animals are nearest to the door, notwithstanding which the hyæna will "pass by the calves and take the children from under the mother's kaross; and this in such a gentle and cautious manner, that the poor parent is unconscious of her loss, until the cries of her little innocent have reached her from without, when it has been a close prisoner in the jaws of the monster." Many years ago, when animals were kept at the Tower of London, the den of a spotted hyæna required some repair. "The carpenter," says Mrs. Bowdich, "nailed a thick oaken plank upon the floor, about seven feet long, putting at least a dozen nails into it, each longer than his middle finger. At one end of this piece of wood there was a small projection, and not having a proper chisel with him by which he might remove it, the man returned to his shop to fetch one. While he was absent some persons came to see the animals, and the hyæna was let down by the keeper into the part of the den in which the carpenter had been at work. Directly the beast saw the projecting piece of wood he seized it with his teeth, tore the plank up, and drew out every nail with the utmost ease; which action will give a good idea of the muscular strength of this creature."

A Narrow Sparman tells an amusing story of the daring Escape. and the fright of a hyæna, as follows: "One night, at a feast near the Cape, a trumpeter who had made himself drunk with liquor was carried out of doors and laid on the grass, in order that the air might both cool and sober him. The scent of the man soon attracted a spotted hyæna, which threw him on his back, and carried him away towards Table Mountain. The hyæna doubtless supposed that the senseless drunkard was a corpse, and consequently a fair prize. In the meantime the musician awoke, and was at once sufficiently sensible to know the danger of his situation, and to sound the alarm with his trumpet, which he fortunately carried at his side. The hyæna, as it may be 
imagined, was greatly frightened in its turn, and immediately ran away, leaving the trumpeter, it is to be hoped, 'a wiser man' for his extraordinary ride. It is remarkable that the soldier was not seriously injured by the hyæna, for the teeth of the animal were fortunately fastened in the coat and not in the flesh of the man."

Animals of Animals of the dog kind, are neither so the Dog Kind. numerous, nor, in general, so ferocious as those of the panther or cat kind. The principal species are the wolf, the jackal, the fox, and the dog. This class may be principally distinguished by their claws, which have no sheath like those of the cat kind, but are placed at the point of each toe, without the capability of being stretched forward or drawn back. The nose, as well as the jaw, of all the dog kind, is longer than in the cat; the body in proportion more strongly made, and covered with hair instead of fur. They also far exceed the other kind in the sense of smell, the olfactory nerves being diffused upon a very extensive membrane within the skull, which accounts for their surprising acuteness in this sense.

The Wolf. The Wolf is about three feet and a half long, and about two feet and a half high, larger than our great breed of mastiffs, which are seldom more than three feet by two. He bears a great resemblance to the dog, but is much stronger, and the length of his hair contributes still more to his robust appearance. The feature which principally distinguishes the visage of the wolf from that of the dog, is the eye, which opens slantingly upwards in the same direction with the nose; whereas, in the $\mathrm{dog}$, it opens more at right angles with the nose, as in man. The colour of the eyeballs in the wolf, is a fiery green, giving his visage a fierce and formidable air. $\mathrm{He}$ generally hides by day in the thickest coverts, and only ventures out at night; when, sallying forth over the country, he keeps peering round the villages, and carries off such animals as are not under protection-attacks 
the sheep-fold, scratches up and undermines the thresholds of doors where the sheep are housed, enters furiously, and destroys all before he begins to fix upon and carry off his prey. The wolf has great strength, particularly in his foreparts, and the muscles of his neck and jaws. He carries off a sheep in his mouth without letting it touch the ground, and runs with it much faster than the shepherds who pursue him; so that nothing but the dogs can overtake and oblige him to quit his prey. Notwithstanding his great strength, cunning, and agility, the wolf being the declared enemy of man, is often hard pressed for subsistence; he has always a gaunt and starved appearance, and, indeed, often dies of hunger. He has been hunted down, and is now rarely to be found in civilized countries.

The Fox. The Fox is of a much more slender make than the wolf, and not nearly so large, being little more than two feet long. The tail is longer and more bushy, the nose smaller, approaching nearer to that of the greyhound, and its hair softer. Its eyes, however, are obliquely set, like those of the wolf. The fox has long been famous for cunning; he is patient and prudent, and gains by address what is denied to his courage or strength. $\mathrm{He}$ is most destructive to poultry. When he gets into a farm-yard, he begins by levelling all the poultry without remorse, and carrying off a part of the spoil, he hides it at some convenient distance. Returning, he carries oft another fowl, which he hides in like manner, but not in the same place; and this he repeats several times, until the approach of day, or the noise of the domestics, warns him to retire to his hole. He often destroys a large quantity of game, seizing the partridge and quail while sitting on their nests. He even eats rats, mice, serpents, toads, and lizards. In vain does the hedge-hog roll itself up into a ball to oppose him; he teases it until it is obliged to appear uncovered, and then devours it. Besides the common Fox (Vulpes Vulgaris), there are numerous varieties, of which the Tahaleb or Egyptian Fox and the Fennec (Feneca Zaarensis) 
of North Africa, the Kit Fox, the Red, the Grey and the Silver Fox of North America, and the Arctic Fox (Leucocyon lagopus) are the best known.

The Jackal. The Jackal, one of the most common of wild animals in the East, is about the size of the fox, but in shape it more nearly resembles the wolf. Its colour is a bright yellow, or sorrel. Its cry is a howl, mixed with barking, and a lamentation resembling that of human distress. The jackal may be considered as the vulture of the quadruped kind; the most putrid substances that once had life, are greedily devoured. Like the hyæna, the jackals scratch up with their feet the new-made grave, and devour the contents, however decomposed. While at this dreary work, they make a mournful cry, like that of children under chastisement, and having thus dug up the body, they amicably share it. In countries, therefore, where they abound, the people are obliged to beat the earth over the grave, and mix it with thorns, to prevent the jackals from scraping it away. The jackal never goes alone, but always in packs of forty or fifty together. They watch the burying-grounds, follow armies, and keep in the rear of caravans. The jackal, after having tired down its prey, is often deprived of the spoil by the lion, the panther, -or the tiger, whose appetites are superior to their swiftness; these attend its call, and devour the prey which it has run down by its unceasing perseverance; and this circumstance has given rise to the erroneous opinion, that the jackal is the lion's provider. The jackal is found in some parts of Europe and abounds in most parts of Asia. Those of the warmest climates are the largest, and their colour is rather of a reddish brown than of that beautiful yellow by which the smaller jackals are distinguished. Like the Fox it forms burrows in the earth and emits an offensive odour.

The wolf's

"The Wolf," says Professor Duncan in "Cassell's

Mode of Natural History", " usually lives in solitary places Attack. in mountains; but in Spain he is said sometimes 
to make his lair in corn-fields, in close proximity to inhabitated dwellings. Here he lives with his wife and family, usually cache' during the day, and issuing forth at night to take his prey. During the warmer periods of the year wolves, as a rule, hunt each one for himself, but in winter they often unite into great packs, and pursue their prey over the snow at a rapid pace and with indomitable perseverance. Swift and untiring must be the animal which, on an open plain, can escape from them; even the horse, perfectly constructed as he is for rapid running, is almost certain to succumb, unless he can reach a village before his pace begins to flag. They never spring upon an animal from an ambush-the nearest approach ever made to such a mode of attack being their practice of attacking sheepfolds by leaping into the midst of the flock and killing right and left; when they reach their prey, too, the first onslaught is made with their teeth, and never by a blow of the paw. Thus, a wolf's attack-like that of all members of the genus Canis-is entirely different from a cat's. The cat lies in ambush all alone, springs upon the passing prey, which if he misses he scarcely ever pursues, and kills by a blow of the paw. The dog and wolf attack openly, sometimes alone, but oftener in company, pursue their prey with unflagging energy until it falls a victim, and give the death-wound at once with their teeth."

The Wolf's That the wolf sometimes employs cunning as

Cunning well as savagery in seeking his prey is shown by the following story from "Broke's Travels in the North of Sweden ": "I observed, on setting out from Sormjole, the last post, that the peasant who drove my sledge was armed with a cutlass; and, on inquiring the reason, was told that, the day preceding, while he was passing in his sledge the part of the forest we were then in, he had encountered a wolf, which was so daring, that it actually sprang over the hinder part of the sledge he was driving, and attempted to carry off 
a small dog which was sitting behind him. During my journey from Tornea to Stockholm, I heard everywhere of the ravages committed by wolves, not upon the human species or the cattle, but chiefly upon the peasants' dogs, considerable numbers of which had been devoured. I was told that these were the favourite prey of this animal; and that, in order to seize upon them with the greater ease, it puts itself into a crouching posture, and begins to play several antic tricks, to attract the attention of the poor dog, which, caught by these seeming demonstrations of friendship, and fancying it to be one of his own species, from the similarity, advances towards it to join in the gambols, and is carried off by its treacherous enemy. Several peasants that I conversed with mentioned their having been eye-witnesses of this circumstance."

The Wolf's Mr. Lloyd in his "Field Sports in the North Cowardice. of Europe" gives a remarkable illustration of the cowardice of the wolf when caught in a trap. "A peasant near St. Petersburg," says Mr. Lloyd, "when one day in his sledge, was pursued by eleven of these ferocious animals. At this time he was only about two miles from home, towards which he urged his horse at the very top of his speed. At the entrance to his residence was a gate, which happened to be closed at the time; but the horse dashed this open, and thus himself and his master found refuge within the court-yard. They were followed, however, by nine out of the eleven wolves; but, very fortunately, at the instant these had entered the enclosure, the gate swung back on its hinges, and thus they were caught as in a trap. From being the most voracious of animals, the nature of these beasts-now that they found escape impossible-became completely changed: so far, indeed, from offering molestation to any one, they slunk into holes and corners, and allowed themselves to be slaughtered almost without making resistance."

Eunted by Many terrible stories are told of the depredaWolves. tions caused by packs of wolves, especially in 
Russia, and of the desperate adventures travellers have met with when attacked by them. The story of the Russian peasant, who, to save his master's family, leaped out of the sledge and faced the pack alone, thus delaying the wolves by his own self-sacrifice, while the sledge proceeded on its journey, is one of these. In contrast to this is the story of the Russian woman, given by Mr. Lloyd in the work already quoted.

A Terrible A woman, accompanied by three of her children, Alternative. was one day in a sledge, when they were pursued by a number of wolves. She put the horse into a gallop, and drove towards her home with the utmost speed. She was not far from it; but the ferocious animals gained upon her, and were on the point of rushing on to the sledge. For the preservation of her own life and that of the remaining children, the poor, frantic creature cast one of them to her bloodthirsty pursuers. This stopped their career for a moment; but, after devouring the poor child, they renewed the pursuit, and a second time came up with the vehicle. The mother, driven to desperation, resorted to the same horrible expedient, and threw another of her offspring to her ferocious assailants. The third child was also sacrificed in the same way, and soon after the wretched being reached her home in safety. Here she related what had happened, and endeavoured to palliate her own conduct by describing the dreadful alternative to which she had been reduced. A peasant, however, who was among the bystanders, and heard the recital, took up an axe, and with one blow cleft her skull in two, saying at the same time, "that a mother who could thus sacrifice her children for the preservation of her own life, was no longer fit to live." The man was committed to prison, but the Emperor subsequently granted him a pardon.

A Marvellous Equally terrible and more marvellous is the Fiseape. story of the adventure of a Russian family which took place as recently as the winter of $1894-5$. A peasant 
was riding in a sleigh in company with his wife and child, when he became aware that they were being pursued by wolves. $\mathrm{He}$ urged the horses to their utmost speed but it soon became evident that the wolves would overtake them before they could reach a place of safety. Urged to desperation, the peasant ordered his wife to throw the child to the wolves, hoping thereby to gain time and thus escape. The wife refused to part with her little one, whereupon an altercation ensued, during which the peasant tried to drag the child from her arms with a view to throwing it to the wolves himself. In the struggle both mother and child fell from the vehicle, and with a lightened load the horses dashed forward at an even greater speed. For some apparently unaccountable reason, however, the wolves took no notice of the mother and child and continued to pursue the sleigh, possibly anticipating the larger meal that the horses would supply. In this they were not disappointed, for they succeeded in overtaking the sleigh, and the peasant and the horses fell victims to their ravage. In the meantime the mother and child found their way to a farm house where they were sheltered until danger was past.

Tame Notwithstanding his natural fierceness, the

Wolves. wolf becomes tame under kindly treatment, and shows much affection for those who cherish him. Instances are common in which wolves have remembered their benefactors, after years of absence, and have shown every demonstration of joy on recognition. They have even been harnessed and taught to draw carriages and to fulfil other useful offices. With wolves, as with many other animals, hunger and thirst are apparently the principal causes of savagery and the struggle for existence the main cause of rapacity and cruelty.

The Cunning The cunning of the fox is proverbial and if of the Fox. only one half of the stories told about him are true, there are quite sufficient to invest him with a degree of 
artfulness which is apparently unique. The extraordinary way in which he will feign himself dead, whether when hunting or being hunted, is a proof of this, as are also the various tricks he will resort to, to throw his pursuers off the scent. Captain Brown tells a story of a fox who leapt a high wall and crouched under it on the further side until the hounds had passed over, and then quietly returned, giving them the slip. Another fox who suddenly baffled two blood hounds who were in hot pursuit, was discovered lying full length upon a log of wood from which at first it was difficult to distinguish him. When feigning death he is said sometimes to hold his breath and hang out his tongue. He will sometimes baftle his pursuers by hanging on to a branch of a tree.

The Fox as a Mr. St. John tells the following story of the Hunter. fox as a hunter:- Just after it was daylight I saw a large fox come very quietly along the edge of the plantation. He looked with great care over the turf wall into the field, and seemed to long very much to get hold of some of the hares that were feeding in it, but apparently knew that he had no chance of catching one by dint of running. After considering a short time, he seemed to have formed his plans, examined the different gaps in the wall, fixed upon one which appeared to be most frequented, and laid himself down close to it in an attitude like that of a cat at a mouse hole. In the meantime I watched all his plans. $\mathrm{He}$ then with great care and silence scraped a small hollow in the ground, throwing up the sand as a kind of screen. Every now and then, however, he stopped to listen, and sometimes to take a most cautious peep into the field. When he had done this, he laid himself down in a convenient posture for springing on his prey, and remained perfectly motionless, with the exception of an occasional reconnoitre of the feeding hares. When the sun began to rise, they came, one by one, from the field to the plantation: three 
had already come without passing by his ambush, one within twenty yards of him; but he made no movement beyond crouching still more flatly to the ground. Presently two came directly towards him, and though he did not venture to look up, I saw, by an involuntary motion of his ear, that those quick organs had already warned him of their approach. The two hares came through the gap together and the fox, springing with the quickness of lightning, caught one and killed her immediately; he then lifted up his booty and was carrying it off, when my rifle-ball stopped his course."

A Fox-Hunt. Captain Brown tells an amusing story of the resource shown by a fox who was hard pressed near Tamary, Ireland, which is as follows. "After a short chase, Reynard disappeared, having cunningly mounted a turf stack, on the top of which he lay down flat. Finding himself, at last, perceived by one of the hounds, he left his retreat, closely pursued by the pack, ran up a stone wall, from which he sprang on the roof of an adjoining cabin, and mounted to the chimney-top. From that elevated situation he looked all around him, as if carefully reconnoitring the coming enemy. A cunning old hound approached, and, having gained the summit of the roof, had already seized the fox in imagination, when, lo! Reynard dropped down the chimney, like a fallen star into a draw-well. The dog looked wistfully down the dark opening, but dared not pursue the fugitive. Meantime, whilst the hound was eagerly inspecting the smoky orifice of the chimney, Reynard, half enrobed in soot, had fallen into the lap of an old woman, who, surrounded by a number of children, was gravely smoling her pipe, not at all expecting the entrance of this abrupt visitor. 'Emiladh deouil!' said the affrighted female, as she threw from her the black and red quadruped: Reynard grinned, growled, and showed his fangs; and when the sportsmen, who had secured the door, entered, they found him in possession of the kitchen, the old woman and the children having retired, 
in terror of the invader, to a corner of the room. The fox was taken alive."

The Arctic The Arctic Fox which is of a beautiful white Fox. colour is found, according to Captain James Ross, in the highest northern latitudes, even in the winter. In the late autumn the younger generation make their way south and congregate in the neighbourhood of Hudson's Bay, returning north in the early spring of the following year. They are gregarious, living in companies in burrows in sandy places. wild Dogs. Wild dogs abound in various parts of the world, of which the Dingos of Australia, the Dholes of India and the Aguaras of South America are examples. The wild dogs of the East are familiar to all readers of Eastern travels. A writer in the Times newspaper describes the dogs of Constantinople, as "omnipresent, lawless, yet perfectly harmless dogs," which perform valuable but ill requited service as scavengers of the city. He says:- "In shape, in countenance, in language, in their bandy legs, pointed noses, pricked up ears, dirty yellow coats, and bushy tails, they could be hunted as foxes in Gloucestershire. They are," he continues, "up and doing from sunset to sunrise, and enjoy the refreshment of well-earned, profound sleep almost throughout the day. They are not only homeless and masterless but have also a sovereign contempt for bed or shelter. There is a time it would seem, when sleep comes upon them-all of themlike sudden death; when all squat down, coil themselves up, nose to tail, wherever they chance to be-on the footpath, in the carriage way, in the gutter-and there lie in the sunshine, in the pelting rain, yellow bundles, hardly distinguishable from the mud. The Constantinople dog never learns to wag his tail; he never makes up, never looks up to a human being, never encourages or even notices men's advances. He is not exactly sullen, or cowed, or mistrustful; he is simply cold and distant as an Englishman is said to be when not introduced." 
"The Dingo, the wild dog of Australia," says Mrs. Bowdich "roams in packs through that vast country; has a broad head; fierce oblique eyes; acute muzzle; short, pointed, erect ears; tail bushy, and never raised to more than a horizontal position. He does not bark, but howls fearfully; is extremely sagacious, and has a remarkable power of bearing pain. When beaten so severely as to be left for dead, he has been seen to get up and run away. A man proceeded to skin one, not doubting that life was extinct, and after proceeding a little way with the operation, he left the hut to sharpen his knife. When he returned, the poor animal was sitting up, with the loose skin hanging over one side of his face." The Dhole of India, similarly hunts in packs, attacking and destroying even the tiger. Their sense of smell is very acute, their bark similar to that of a hound, their colour red or sandy. They have long heads, oblique eyes, long erect ears; and very powerful limbs. The Aguaras of South America, says Mrs. Bowdich, resemble foxes. "They are silent if not dumb, and appear to congregate in families rather than packs. They have a peculiar propensity to steal and secrete without any apparent object in so doing."

The Dog. The dog divides with the horse the honour of being the most intimate and devoted of the servants of mankind. "His origin," says Mr. Jesse "is lost in antiquity. We find him occupying a place in the earliest pagan worship; his name has been given to one of the first-mentioned stars of the heavens, and his effigy may be seen in some of the most ancient works of art. Pliny was of opinion that there was no domestic animal without its unsubdued counterpart, and dogs are known to exist absolutely wild in various parts of the old and new world." Whether the dog of civilization is a descendant of these wild dogs, or whether the wild dog is the progeny of domestic varieties relapsed into a condition of savagery, and whether both are descended from the wolf and the jackal has often been discussed. Certain it is that 
many of the species which now obtain are in certain characteristics at least the result of artificial breeding. In its domestic state, the dog is remarkable for its usefulness, obedience, and attachment to its master; and the great variety of breeds that are trained and educated for our benefit or amusement, are almost too numerous to be mentioned. The principal are, the greyhound, noted for his speed; the Nezefoundland dog, remarkable for his size, sagacity, and benevolence; the shepherd's dog, perhaps the most useful of all; the spaniel, the barbel, and the setter, useful in hunting; the pointer, the staunchest of all dogs; the Dalmatian or coach-dog, with a skin beautifully spotted; the terrier, useful for destroying vermin; the blood-hound, formerly used for tracing criminals; the harrier, beagle, and foxhound, distinguished for their quick sense of smell; and the bull-dog, and mastiff, which are our watch-dogs.

The Dog's Un. Many marvellous instances are on record of the derstanding. dog's capacity for understanding not only the direct commands of his master, to which of course he may be easily trained, but also, sometimes, the drift of conversations in which his master may engage.

The Rev. James Simpson of Edinburgh had a fine Newfoundland $\mathrm{dog}$ of which some good stories are told. On one occasion, however, Mr. Simpson happening to remark to a friend in the dog's hearing that, as he was about to change his residence, he would have to part with his dog, the dog took the hint, left the house and was never heard of again. Sheep dogs have been known to take very apparent interest in conversations upon the subject of their profession, and to anticipate the word of command by their perception of the drift of the remarks. Mr. St. John, in his "Highland Sports", gives a remarkable illustration of the way in which a shepherd's dog understood the conversation of his master:- "A shepherd once, to prove the quickness of his dog, who was lying before the fire in the house where we were talking, said to me, in the 
middle of a sentence concerning something else, 'I'm thinking, sir, the cow is in the potatoes.' Though he purposely laid no stress on these words, and said them in a quiet, unconcerned tone of voice, the dog, who appeared to be asleep, immediately jumped up, and leaping through the open window, scrambled up the turf roof of the house, from which he could see the potato field. He then (not seeing the cow there) ran and looked into the byre, where she was, and finding that all was right, came back to the house. After a short time the shepherd said the same words again, and the dog repeated his look-out; but on the false alarm being a third time given, the dog got up, and wagging his tail, looked his master in the face with so comical an expression of interrogation, that we could not help laughing aloud at him, on which, with a slight growl, he laid himself down in his warm corner, with an offended air, as if determined not to be made a fool of again."

The well known story of Sir Walter Scott's dog, supplied by him to Captain Brown, is another illustration. "The wisest dog I ever had," said Sir Walter, "was what is called the bull-dog terrier. I taught him to understand a great many words, insomuch that I am positive that the communication betwixt the canine species and ourselves might be greatly enlarged. Camp once bit the baker, who was bringing bread to the family. I beat him, and explained the enormity of his offence; after which, to the last moment of his life, he never heard the least allusion to the story, in whatever voice or tone it was mentioned, without getting up and retiring ints the darkest corner of the room, with great appearance of distress. Then if you said, "the baker was well paid,' or, 'the baker was not hurt after all,' Camp came forth from his hiding-place, capered, and barked, and rejoiced. When he was unable, towards the end of his life, to attend me when on horseback, he used to watch for my return, and the servant would tell him 'his master was coming down 
the hill, or through the moor,' and although he did not use any gesture to explain his meaning, Camp was never known to mistake him, but either went out at the front to go up the hill, or at the back to get down to the moor-side. He certainly had a singular knowledge of spoken language."

One of the most remarkable illustrations of the dog's capacity for understanding is probably that given by Mrs. Bowdich, as follows:

"Professor Owen was walking with a friend, by the side of a river, near its mouth, on the coast of Cornwall, and picked up a small piece of sea-weed. It was covered with minute animals; and Mr. Owen observed to his companion, throwing the weed into the water, 'If this small piece affords so many treasures, how microscopically rich the whole plant must be! I should much like to have one.' The gentlemen walked on, but hearing a splashing in the water, turned round, and saw it violently agitated. 'It is Lion!' both exclaimed; 'what can he be about? He was walking quietly enough by our side a minute ago.' At one moment they saw his tail above the water, then his head raised for a breath of air, then the surrounding element shook again, and at last he came ashore, panting from his exertions, and laid a whole plant of the identical weed at Mr. Owen's feet. After this proof of intelligence, it will not be wondered at, that when Lion was joyfully expecting to accompany his master and his guest on an excursion, and was told to go and take care of and comfort Mrs. Owen, who was ill, he should immediately return to the drawing-room and lay himself by her side, which he never left during the absence of his owner, his countenance alone betraying his disappointment, and that only for a few minutes."

The Dog's Sense Dogs have a remarkable sense of locality, of Locality. and will find their way to a spot they have once visited with an unerring instinct under circumstances which make it impossible for them to rely entirely upon their 
sense of scent. Some of the stories told of the extraordinary journeys made by dogs, apparently without anything to guide them but their natural instinct, seem almost incredible.

Captain Brown tells a story of a gentleman of Glasgow, who was unfortunately drowned in the river Oder while bathing during a continental tour. A Newfoundland dog, who was his travelling companion, made every effort to save him, but failing to do so, found his way either to Frankfort, or Hamburgh, where he went on board a vessel bound for England, from which he landed somewhere on the coast, finding his way ultimately to the person from whom he had been originally purchased, and who lived near Holyrood palace.

Another dog who, on arriving in England from Newfoundland, was given to a gentleman in London, was sent by him to a friend in Scotland, by water. The dog, however, made his escape and found his way back to his old master at Fish Street Hill, London, though as Mr. Jesse puts it "in so exhausted a state that he could only express his joy at seeing his master and then die."

This instinct seems to be common to many varieties of dogs. Captain Brown tells of a Dalmatian or coach-dog which Lord Maynard lost in France, and which he found at his house on his return to England, though how. it had got there he never could trace. It is not necessary, says Captain Brown, that the dog shall have previously travelled the ground by which it returns. A person who went by sea from Aberdeen to Leith, lost his dog at the latter place, and found it on his return at Aberdeen. It must have travelled over a country unknown to it, and have crossed the firths of Forth and Tay.

Illustrations might easily be multiplied. Mr. Jesse tells of a dog which was presented to the Captain of a collier by a gentleman residing at Wivenhoe in Essex and which on being landed at Sunderland found its way back to its old master, and also of a spaniel belonging to Colonel Hardy which after 
accompanying him from Essex to Bath in a post chaise, found its way back through London, a distance of 140 miles in three days.

Perhaps a more remarkable instance is that recorded of his dog by M. d'Obsonville. This animal accompanied his master and a friend from Pondicherry to Bengalore, a distance of more than nine hundred miles. M. D'Obsonville says, "Our journey occupied nearly three weeks; and we had to traverse plains and mountains, and to ford rivers, and go along bypaths. The animal, which had certainly never been in that country before, lost us at Bengalore, and immediately returned to Pondicherry. He went directly to the house of my friend, M. Beglier, then commandant of artillery, and with whom I had generally lived. Now, the difficulty is not so much to know how the dog subsisted on the road (for he was very strong, and able to procure himself food), but how he should so well have found his way after an interval of more than a month! This was an effort of memory greatly superior to that which the human race is capable of exerting."

Dog Friendships That dogs make very strong friendships and Enmitios. among themselves is attested by many an affecting story. A Radnorshire lady, who married and went to reside in Yorkshire, afterwards paid a visit to her old home where her father, before her marriage, had kept two or three sheep-dogs of whom she was very fond. Having retired from business, her father had disposed of all but one dog, and upon her arrival this one met the lady with every demonstration of delight and, that same night, went a distance of seven miles to a farmhouse where one of the other dogs who had become blind, then lived. In the morning when the lady went to the door she saw not only the dog which had given her such a glad reception on the previous day, but also the old blind one, which had evidently been brought by the other dog to welcome her. When the second night came the old blind dog was taken back to its home by the 
same dog, which afterwards returned, having travelled a distance of twenty-eight miles to give pleasure to his old blind friend.

Instances might easily be multiplied but we must content ourselves with one of a very different character from Colonel Hamilton Smith's "Cyclopædia of Natural History." "In the neighbourhood of Cupar, in the county of Fife, there lived two dogs, mortal enemies to each other, and who always fought desperately whenever they met. Capt. $\mathrm{R}$ - was the master of one of them, and the other belonged to a neighbouring farmer. Capt. $\mathrm{R}$ __'s dog was in the practice of going messages, and even of bringing butchers' meat and other articles from Cupar. One day, while returning, charged with a basket containing some pieces of mutton, he was attacked by some of the curs of the town, who, no doubt, thought the prize worth contending for. The assault was fierce, and of some duration; but the messenger, after doing his utmost, was at last overpowered and compelled to yield up the basket, though not before he had secured a part of its contents. The piece saved from the wreck he ran off with, at full speed, to the quarters of his old enemy, at whose feet he laid it down, stretching himself beside it till he had eaten it up. A few snuffs, a few whispers in the ear, and other dog-like courtesies, were then exchanged; after which they both set off together for Cupar, where they worried almost every dog in the town; and, what is more remarkable, they never afterwards quarrelled, but were always on friendly terms." This story also illustrates another characteristic of the dog family. Dogs combine for purposes of offence and defence. Cats stand or fall alone.

Dog The foregoing is also a proof of the faculty by Language. which animals can communicate their ideas to each other which in dogs is particularly remarkable. There are many curious anecdotes recorded, illustrative of this faculty. "At Horton, England, about the year 1818, a gentle- 
Inan from London took possession of a house, the former tenant of which had moved to a farm about half a mile off. The new inmate brought with him a large French poodle $\mathrm{dog}$, to take the duty of watchman, in the place of a fine Newfoundland dog, which went away with his master; but a puppy of the same breed was left behind, and he was instantly persecuted by the poodle. As the puppy grew up, the persecution still continued. At length, he was one day missing for some hours; but he did not come back alone; he returned with his old friend, the large house-dog, to whom he had made a communication; and in an instant the two fell upon the unhappy poodle, and killed him before he could be rescued from their fury. In this case, the injuries of the young dog must have been made known to his friend; a plan of revenge concerted; and the determination to carry that plan into effect formed and executed with equal promptitude. The following story, which illustrates, even in a more singular manner, the communication of ideas between dogs, was told by a clergyman, as an authentic anecdote. A surgeon of Leeds found a little spaniel who had been lamed. He carried the poor animal home, bandaged up his leg, and, after two or three days, turned him out. The dog returned to the surgeon's house every morning, till his leg was perfectly well. At the end of several months, the spaniel again presented himself, in company with another dog, who had also been lamed; and he intimated, as well as piteous and intelligent looks could intimate, that he desired the same kind assistance to be rendered to his friend, as had been bestowed upon himself. A similar circumstance is stated to have occurred to Moraut, a celebrated French surgeon."

The Dog's Many instances have been chronicled of the Intelligence. actions of dogs, which seem clearly the result of a process of reasoning. Mr. Jesse tells of a dog who was sent to fetch two hats which had been left lying upon the 
grass. After several unsuccessful attempts to carry the two together in his mouth, he laid them on the ground, placed the smaller within the larger, pressed it down with his foot, and then easily carried them to his master. Instances are recorded of dogs who while always ready to perform a useful service, absolutely refused to act for the amusement of on-lookers or to discharge unnecessary duties. Thus a dog who would go into the water to retrieve a wild duck would refuse to fetch anything that had been thrown in for the purpose of displaying his agility, and another who was accustomed to ring the servants' bell at the bidding of his mistress refused to do so when told while the servant was in the room, and if repeatedly commanded to do so, would lay hold of the servant's coat and attempt to drag him to his mistress. These illustrations seem to show a power of discrimination not usually credited to animals. Of the intelligence shown by dogs which have been trained, the following story from the "Percy Anecdotes" is at once a remarkable and an amusing illustration. "One day, when Dumont, a tradesman of the Rue St. Denis, was walking in the Boulevard St. Antoine with a friend, he offered to lay a wager with the latter, that if he were to hide a six-livre piece in the dust, his dog would discover and bring it to him. The wager was accepted, and the piece of money secreted, after being carefully marked. When the two had proceeded some distance from the spot, M. Dumont called to his dog that he had lost something, and ordered him to seek it. Caniche immediately turned back, and his master and his companion pursued their walk to the Rue St. Denis. Meanwhile a traveller, who happened to be just then returning in a small chaise from Vincennes, perceived the piece of money, which his horse had kicked from its hiding-place; he alighted, took it up, and drove to his inn, in the Rue Pont-aux-Choux. Caniche had just reached the spot in search of the lost piece when the stranger picked it up. He followed the 
chaise, went into the inn, and stuck close to the traveller. Having scented out the coin which he had been ordered to bring back in the pocket of the latter, he leaped up incessantly at and about him. The traveller, supposing him to be some dog that had been lost or left behind by his master, regarded his different movements as marks of fondness; and as the animal was handsome, he determined to keep him. He gave him a good supper, and on retiring to bed took him with him to his chamber. No sooner had he pulled off his breeches, than they were seized by the dog; the owner conceiving that he wanted to play with them, took them away again. The animal began to bark at the door, which the traveller opened, under the idea that the dog wanted to go out. Caniche snatched up the breeches, and away he flew. The traveller posted after him with his night-cap on, and literally sans culottes. Anxiety for the fate of a purse full of gold Napoleons, of forty francs each, which was in one of the pockets, gave redoubled velocity to his steps. Caniche ran full speed to his master's house, where the stranger arrived a moment afterwards breathless and enraged. He accused the dog of robbing him. 'Sir,' said the master, 'my dog is a very faithful creature; and if he has run away with your breeches, it is because you have in them money which does not belong to you.' The traveller became still more exasperated. 'Compose yourself, sir,' rejoined the other, smiling; 'without doubt there is in your purse a six-livre piece, with such and such marks, which you have picked up in the Boulevard St. Antoine, and which I threw down there with the firm conviction that my dog would bring it back again. This is the cause of the robbery which he has committed upon you.' The stranger's rage now yielded to astonishment; he delivered the six-livre piece to the owner, and could not forbear caressing the dog which had given him so much uneasiness, and such an unpleasant chase." 
Dogss That dogs sometimes make mistakes in the Mistakes. exercise of their intelligence, with somewhat ludicrous results, is of course true. A dog once accompanied a gentleman's servant to a tailor's with a coat of his master's which needed repair. Having his suspicions with regard to the transaction, the dog watched his opportunity, seized the coat from the counter and carried it back with evident satisfaction to his master. Another dog caused great amusement at a swimming match by insisting upon the rescue of one of the competitors. Dogs have also been known to cause both amusement and consternation by leaping upon the stage to rescue the defenceless characters of the melodrama from the hands of the heavy villain of the play. The story of the dog who failed to recognise his master who had been bathing, and who therefore refused to allow him to have his clothes, is probably apochryphal, but if true is another illustration of the awkwardness of dogs' mistakes.

The Eskimo Colonel Hamilton Smith in his classification of Dog. dogs begins with those which belong nearest to the arctic circle, and it will be convenient to follow his order in so far as space will allow. Speaking of the Eskimo dog Captain Lyon says:- "Having myself possessed during our hard winter a team of eleven fine dogs, I was enabled to become better acquainted with their good qualities than could possibly have been the case by the casual visits of the Esquimaux to the ships. The form of the Esquimaux dog is very similar to that of our shepherd's dog in England, but it is more muscular and broad-chested, owing to the constant and severe work to which he is brought up. His ears are pointed, and the aspect of the head is somewhat savage. In size a fine dog about the height of the Newfounclland breed, but broad like a mastiff in every part except the nose. The hair of the coat is in summer, as well as in winter, very long, but during the cold season a soft, downy under-covering is found, which does not appear in warm weather. Young 
dogs are put into harness as soon as they can walk, and being tied up, soon acquire a habit of pulling, in their attempts to recover their liberty, or to roam in quest of their mother. When about two months old, they are put into the sledge with the grown dogs, and sometimes eight or ten little ones are under the charge of some steady old animal, where, with frequent and sometimes severe beatings, they soon receive a competent education. Every dog is distinguished by a particular name, and the angry repetition of it has an effect as instantaneous as an application of the whip, which instrument is of an immense length, having a lash from eighteen to twenty-four feet, while the handle is one foot only; with this, by throwing it on one side or the other of the leader, and repeating certain words, the animals are guided or stopped: When the sledge is stopped they are all taught to lie down, by throwing the whip gently over their backs, and they will remain in this position even for hours, until their master returns to them. A walrus is frequently drawn along by three or four of these dogs, and seals are sometimes carried home in the same manner, though I have in some instances seen a dog bring home the greater part of a seal in panniers placed across his back. Cold has very little effect on them; for although the dogs at the huts slept within the snow passages, mine at the ships had no shelter, but lay alongside, with the thermometer at $42^{\circ}$ and $44^{\circ}$, and with as little concern as if the weather had been mild. I found, by several experiments, that three of my dogs could draw me on a sledge, weighing one hundred pounds, at the rate of one mile in six minutes; and as a proof of the strength of a well-grown dog, my leader drew one hundred and ninety-six pounds singly, and to the same distance, in eight minutes. At another time seven of my dogs ran a mile in four minutes, drawing a heavy sledge full of men. Afterwards, in carrying stores to the Fury, one mile distant, nine dogs drew one thousand six hundred and eleven pounds in the space of nine minutes, 
When the dogs slackened their pace, the sight of a seal or bird was sufficient to put them instantly to their full speed; and even though none of these might be seen on the ice, the cry of 'a seal!'-'a bear!'-or 'a bird!' \&c., was enough to give play to the legs and voices of the whole pack. The voice and long whip answer all the purposes of reins, and the dogs can be made to turn a corner as dexterously as horses, though not in such an orderly manner, since they are constantly fighting; and I do not recollect to have seen one receive a flogging without instantly wreaking his passion on the ears of his neighbours. The cries of the men are not more melodious than those of the animals; and their wild looks and gestures when animated, give them an appearance of devils driving wolves before them. Our dogs had eaten nothing for forty-eight hours, and could not have gone over less than seventy miles of ground; yet they returned, to all appearance, as fresh and active as when they first set out.”

A Hard Lot. The unhappy condition of the Eskimo dogs under native treatment is pathetically referred to in "Cassell's Natural History," edited by Professor Duncan. The writer says "the horrible savagery of those poor wretches can hardly be wondered at; they live in a country where there is hardly a chance for them in any independent foraging expedition; they are half-starved by their masters, being fed chiefly on frozen walrus hides in the winter, and allowed to shift for themselves in the summer when their services are not required, and are in so perennial and acute a state of hunger that they are ready at any time to eat their own hamess if allowed to do so. It is generally stated that they are perfectly insensible to kindness, and only to be kept in order by a liberal application of the lash, or even of a more formidable weapon; for the Eskimo, if their dogs are refractory, do not scruple to beat them about the head with a hammer, or anything else of sufficient hardness which 
happens to be at hand. They will even beat the poor brutes in this horrible manner until they are actually stunned. Notwithstanding the absolute dependence of the Eslzimo on their dogs, little or no care is taken of them; they receive nothing in any degree approaching petting, and spend all their time in the open air. The chief use of the Eskimo dog is to draw the sledges, which are the only possible conveyances in that frozen land. In all the Arctic expeditions which have been sent out at various times, a good supply of sledge dogs has been one of the greatest desiderata, as without them it would be absolutely impossible to proceed far. No other animal would answer the purpose, both horses and cattle being quite useless in journeys over ice and snow, amongst which the pack of light, active dogs make their way with wonderful ease and safety." The Siberian dogs render equally valuable services to their masters with about an equal measure of appreciation.

The Nowfound- The dog known as the Newfoundland dog land Dog. is one of the handsomest and best beloved of the dog family. $\mathrm{He}$ is distinct from the Labrador dog, which is more slender in make, has a sharper muzzle and is generally "black in colour with a tawny nose and a rusty spot over each eye". The Labrador dog and the Eskimo have been credited with the parentage of the Newfoundland species. At home the Newfoundland is made useful for the purpose of drawing loads, being harnessed to small carts and sleighs for carrying wood and other commodities. Abroad like the prophet who "is not without honour save in his own country", he has been found capable and worthy of much more honourable service, and his fidelity and sagacity have won for him universal esteem. $\mathrm{He}$ is an expert swimmer, his feet being webbed and so peculiarly adapted for the exercise. He takes to the water as though it were his natural element, and has so often carried the line to sinking ships, and rescued persons about to drown that such incidents 
have become quite common. The tribute paid to him by Sir Edwin Landseer, when he named his famous picture of him "a distinguished member of the humane society", was no more poetical than just. Volumes might be filled with stories of his intelligence and prowess, and it is difficult within present limits to select a due variety of characteristic anecdotes. The Newfound- One of the most marked characteristics of land's Generosity. the Newfoundland dog is his generosity to a fallen foe. His temper is said to be uncertain, though this has been questioned by some who have had large experience of him under varying circumstances. $\mathrm{Be}$ this as it may, there are many stories told to his honour of his generosity to his enemies in the moment of victory. A Newfoundland dog, who had for some time treated with becoming dignity the impudence of some mongrels who were amusing themselves by snapping and snarling at his heels, suddenly turned and sent the crowd of persecutors flying in all directions, except the ringleader, who fell sprawling in the middle of the street, where he was about to receive the punishment he deserved when a cable car came dashing down the hill, right upon the dogs. The big dog saw the danger at once and sprang aside, but his enemy remained upon his back, too terrified to notice anything. The Newfoundland took in the situation, in a moment sprang back in front of the car, seized the cur in his teeth, and snatched him, still whining and begging for mercy, out of the very jaws of death. Laying him in the gutter, he gave a good-natured wag or two of his tail and went his way. Another Newfoundland much bothered by a small cur who was for ever barking at his heels, but who treated his assailant with sublime indifference, was on one occasion aroused to adopt drastic measures by receiving a bite on his leg. Seizing the cur by the loose skin of his back he carried him down to the quay of Cork and after letting him dangle over the water for a little while, dropped him into it. After watching the animal struggle with the 
water until nearly exhausted, the Newfoundland plunged in and rescued him. Mr. Jesse gives a fine illustration of this canine chivalry, witnessed at Donaghadee. "The one dog in this case was also a Newfoundland, and the other was a mastiff. They were both powerful dogs; and though each was good-natured when alone, they were very much in the habit of fighting when they met. One day they had a fierce and prolonged battle on the pier, from the point of which they both fell into the sea; and as the pier was long and steep, they had no means of escape but by swimming a considerable distance. Throwing water upon fighting dogs is an approved means of putting an end to their hostilities; and it is natural to suppose that two combatants of the same species tumbling themselves into the sea would have the same effect. It had; and each began to make for the land as best he could. The Newfoundland being an excellent swimmer, very speedily gained the pier, on which he stood shaking himself; but at the same time watching the motions of his late antagonist, which, being no swimmer, was struggling exhausted in the water, and just about to sink. In dashed the Newfoundland dog, took the other gently by the collar, kept his head above water, and brought him safely on shore. There was a peculiar kind of recognition between the two animals; they never fought again; they were always together: and when the Newfoundland dog had been accidentally killed by the passage of a stone waggon on the railway over him, the other languished and evidently lamented for a long time."

The New- The quickness with which the Newfoundland foundland's will realise the danger of a situation and the of Danger. promptitude with which he will devise a remedy, make him in some cases a more valuable friend in need than a man could be. Human aid would have probably been too slow in the following case related by Mr. Jesse. "In the city of Worchester, one of the principal streets 
leads by a gentle declivity to the river Severn. One day a child, in crossing the street, fell down in the middle of it and a horse and cart, which was descending the hill, would have passed over it, had not a Newfoundland dog rushed to the rescue of the child, caught it up in his mouth, and conveyed it in safety to the foot pavement."

The promptitude with which he will leap into the water to save the drowning, without waiting for any word of command, is another illustration of this faculty. Another case related by Mr. Jesse may be quoted. "In the year I84I, as a labourer, named Rake, in the parish of Botley, near Southampton, was at work in a gravel-pit, the top stratum gave way, and he was buried up to his neck by the great quantity of gravel which fell upon him. He was at the same time so much hurt, two of his ribs being broken, that he found it impossible to make any attempt to extricate himself from his perilous situation. Indeed, nothing could be more fearful than the prospect before him. No one was within hearing of his cries, nor was any one likely to come near the spot. He must almost inevitably have perished, had it not been for a Newfoundland dog belonging to his employer. This animal had been watching the man at his work for some days, as if he had been aware that his assistance would be required; for no particular attachment to each other had been exhibited on either side. As soon, however, as the accident occurred, the dog jumped into the pit, and commenced removing the gravel with his paws; and this he did in so vigorous and expeditious a manner, that the poor man was at length able to liberate himself, though with extreme difficulty. What an example of kindness, sensibility, and I may add reason, does this instance afford us!"

Mr. Youatt gives a remarkable illustration, also quoted by Mr. Jesse, of a Newfoundland's apparent perception of danger of quite another sort. Finding it inconvenient to keep this animal Mr. Youatt had given it to a friend, and four years passed 
before the dog saw his late owner again, when they met quite by chance, the two masters and the dog, on a lonely road between Wandsworth and Kingston. The dog showed every sign of pleasure at meeting his old master, but when they parted faithfully followed the new. Mr. Youatt had not proceeded far, however, when he discovered that the dog had rejoined him and was walking at his side, growling and showing every sign of anger. Looking ahead he discovered two men approaching him stealthily from behind the bushes that skirted the road. "I can scarcely say," says Mr. Youatt, "what I felt; for presently one of the scoundrels emerged from the bushes, not twenty yards from me; but he no sooner saw my companion, and heard his growling, the loudness and depth of which were fearfully increasing, than he retreated, and I saw no more of him or of his associate. My gallant defender accompanied me to the direction-post at the bottom of the hill, and there, with many a mutual and honest greeting, we parted, and he bounded away to overtake his rightful owner. We never met again; but I need not say that I often thought of him with admiration and gratitude."

The Newfound-

A number of well authenticated stories, seem land's Sense of to indicate a certain sense of right and wrong Right and Wrong. as characteristic of the more intelligent dogs; of course the idea of right and wrong being in the case of animals as in the case of men, largely a matter of education. The Newfoundland dog belonging to the Rev. J. Simpson of Potterow Church, Edinburgh, already referred to, on one occasion detained a party of friends which had been entertained by the servants during their master's absence at church, by stationing himself in front of the hall door and preventing their egress until the rev. gentleman's return. Another Newfoundland dog who belonged to a grocer, and who had seen a porter hide money behind a heap of rubbish in a stable,money which he had surreptitiously abstracted from the till,- 
followed an apprentice into the stable on the first opportunity, and scratching away the rubbish exposed the money to view, thus leading to the detection of the thief. It is of course easy to claim too much for actions apparently so intelligent and in estimating them coincidence has to be allowed for; but they are far too numerous to be ignored in estimating canine character. An instance is recorded of a quiet docile dog who refused to allow a visitor to leave a stable, when it was discovered that the man had secreted a bridle in his pocket.

The Newfound- Many illustrations might be given of the land's Fidelity. fidelity which the Newfoundland shows in common with other dogs, but one or two must suffice. A story is told of a dog who picked up a coin which his master had dropped from his purse, and which he kept in his mouth all day, refusing food until his master's return in the evening, when he laid it at his feet, and then attacked his dinner voraciously; another of a dog who on being sent home by his master with a key which he had inadvertently taken with him, was attacked by a dog belonging to a butcher, but who declined the combat until he had delivered the key, but immediately returned and attacking the butcher's dog killed him. In the first case the dog suffered the natural pangs of hunger rather than hazard his master's property, and in the second he postponed the gratification of his natural feeling of revenge until after the execution of his duty.

The Newfound- The tricks to which dogs can be trained, land under though often amusing enough, have not the Training. interest which attaches to the natural display of their faculties, and yet of course there is plenty of scope for the trained dog to supplement his culture by the exercise of his natural gifts, and this he often does. Perhaps one of the most remarkable of trained Newfoundland dogs, was the one possessed by Mr. McIntyre of Regent Bridge, Edinburgh. This dog was trained to perform all kinds of tricks. $\mathrm{He}$ 
would pick his master's hat out from a number of others of the same kind, or indeed almost any article of his master's from a group of similar articles. He would ring the bell to summon the servants, and if there was no bell rope in the room, find and use the hand bell with equal facility. A comb was hidden on the top of a mantel-piece in the room, and the dog required to bring it, which he almost immediately did, although in the search he found a number of articles also belonging to his master, purposely strewed around, all of which he passed over, and brought the identical comb which he was required to find, fully proving that he was not guided by the sense of smell, but that he perfectly understood what was spoken to him. One evening sorne gentlemen being in company, one of them accidentally dropped a shilling on the floor, which, after the most careful search, could not be found. Mr. M. seeing his dog sitting in a corner, and looking as if quite unconscious of what was passing, said to him, "Dandie, find us the shilling and you shall have a biscuit." The dog immediately jumped upon the table and laid down the shilling, which he had previously picked up without having been perceived. Mr. M. having one evening supped with a friend, on his return home could not find his bootjack in the place where it usually lay. He then said to his dog, "Dandie, I cannot find my boot-jack,--search for it." The faithful animal, quite sensible of what had been said to him, scratched at the room-door, which his master opened. Dandie proceeded to a very distant part of the house, and returned carrying in his mouth the boot-jack, which Mr. M. then recollected to have left that morning under a sofa. A number of gentlemen, well acquainted with Dandie, were daily in the habit of giving him a penny which he took to a baker's shop and purchased bread for himself. One of these gentlemen, who lived in James' Square, when passing was accosted by Dandie, in expectation of his usual present. Mr. T. said to him, "I have not a penny 
with me to-day, but I have one at home." Having returned to his house some time after, he heard a noise at the door, which was opened by the servant, when in sprang Dandie to receive his penny. In a frolic Mr. T. gave him a bad one, which he, as usual, carried to the baker, who refused to take the bad coin. He immediately returned to Mr. T.'s, scratched at the door, and when the servant opened it, laid the penny down at her feet, and walked off, seemingly with the greatest contempt. Although Dandie, in general, made an immediate purchase of bread with the money which he received, the following circumstance clearly demonstrates that he possessed more prudent foresight than many who are reckoned rational beings. One Sunday, when it was very unlikely that he could have received a present of money, Dandie was observed to bring home a loaf. Mr. M. being somewhat surprised at this, desired the servant to search the room to see if any money could be found. While she was engaged in this task, the dog seemed quite unconcerned till she approached the bed, when he ran to her, and gently drew her back from it. Mr. M. then secured the dog, which kept struggling and growling while the servant went under the bed, where she found seven pence halfpenny under a bit of cloth. From that time he never could endure the girl, and was frequently observed to hide his money in a corner of a saw-pit, under the dust. When Mr. M. had company, if he desired the dog to see any one of the gentlemen home, he would walk with him till he reached his home, and then return to his master, how great soever the distance might be. Many other stories are told about Dandie but these must suffice. Of their authenticity there seems little doubt; they were recorded by Captain Brown during the lifetime of Dandie and his master.

The

The shepherd's dog (canis domesticus) rivals if sheep Dog. not surpasses most other dogs in intelligence, though his intelligence is less general and more particular 
than that of other dogs, i.e., more special to his own profession and probably more due to training and culture. The principle of heredity operates conspicuously in the case of dogs, and shepherding being one of the oldest occupations of man, the shepherd's dog has probably been under culture for a longer period than any other,-hence his proficiency in his work. Buffon credited him with being "the parent stock of the whole species", and Colonel Smith with civilisation at a very early period. "The sheep dog," says Colonel Smith, "is seldom two feet high, but his make is muscular; the nose rather pointed; the ears erect; and the colour of the hair black and fulvous; the fur is rather long and rough. In great Britain, and more particularly in Scotland, the colours are more mixed with shades of brown, and the ears are often drooping at the tips. The sheep dog is not to be confused with the drover or cattle dog, which is larger and still more rugged in coat, as well as manners.

The

The sheep dog is credited with so many stories sheep Dog's of skill and sagacity, that those unacquainted

Bagacity: with his habits and achievements can scarcely believe the record. He has been known to rival the St. Bernard in tracking both men and sheep who have become buried in the snow, the mastiff in defending his master's property and the Newfoundland in procuring assistance he was unable to render himself. But it is in the pursuit of his special duties that he displays the most remarkable powers; and many illustrations might be given of his extraordinary skill and fidelity. Happily for him he found in the Ettrick Shepherd an historian as well acquainted with his prowess as he was able to record its exercise; from whose writings we are able to quote several remarkable illustrations.

"My dog Sirrah," says he, "was, beyond all comparison, the best dog I ever saw: he was of a surly and unsocial temper,-disdaining all flattery, he refused to be caressed; but his attention to my commands and interests will never 
again, perhaps, be equalled by any of the canine race. Well as I knew him, he often astonished me; for, when hard pressed in accomplishing the task that he was put to, he had expedients of the moment that bespoke a great share of the reasoning faculty.

"About seven hundred lambs, which were once under my care at weaning time, broke up at midnight, and scampered off in three divisions across the hills, in spite of all that I and an assistant lad could do to keep them together. "Sirrah, my man!' said I, in great affliction, 'they are awa'.' The night was so dark that I could not see Sirrah, but the faithful animal heard my words-words such as of all others were sure to set him most on the alert; and without much ado he silently set off in search of the recreant flock. Meanwhile I and my companion did not fail to do all in our power to recover our lost charge. We spent the whole night in scouring the hills for miles around, but of neither the lambs nor Sirrah could we obtain the slightest trace. It was the most extraordinary circumstance that had occurred in my pastoral life. We had nothing for it (day having dawned), but to return to our master, and inform him that we had lost his whole flock of lambs, and knew not what had become of them. On our way home, however, we discovered a body of lambs at the bottom of a deep ravine, called the Flesh Cleuch, and the indefatigable Sirrah standing in front of them, looking all around for some relief, but still standing true to his charge. The sun was then up; and when we first came in view of them, we concluded that it was one of the divisions which Sirrah had been unable to manage until he came to that commanding situation. But what was our astonishment, when we discovered by degrees that not one lamb of the whole flock was wanting! How he had got all the divisions collected in the dark, is beyond my comprehension. The charge was left entirely to himself, from midnight until the rising of the sun; and if all the shepherds in the forest 
had been there to have assisted him, they could not have effected it with greater propriety. All that I can farther say is, that I never felt so grateful to any creature below the sun, as I did to my honest Sirrah that morning."

The

"The late Mr. Steel, flesher in Peebles," says Shoep-dog's James Hogg, "had a bitch whose feats in taking Fidelity. sheep from the neighbouring farms into the Fleshmarket at Peebles, form innumerable anecdotes in that vicinity, all similar to one another. But there is one instance related of her, that combines so much sagacity with natural affection, that I do not think the history of the animal creation furnishes such another. Mr. Steel had such an implicit dependence on the attention of this animal to his orders, that, whenever he put a lot of sheep before her, he took a pride in leaving them to herself, and either remained to take a glass with the farmer of whom he had made the purchase, or took another road to look after bargains or other business. But one time he chanced to commit a drove to her charge at a place called Willenslee, without attending to her condition as he ought to have done. This farm is five miles from Peebles, over wild hills, and there is no regularly defined path to it. Whether Mr. Steel remained behind, or chose another road, I know not; but, on coming home late in the evening, he was astonished at hearing that his faithful animal had not made her appearance with the flock. $\mathrm{He}$ and his son, or servant, instantly prepared to set out by different paths in search of her; but, on their going out to the street, there was she coming with the drove, not one missing; and marvellous to relate, she was carrying a young pup in her mouth! She had been taken in travail on those hills; and how the poor beast had contrived to manage the drove in her state of suffering is beyond human calculation, for her road lay through sheep the whole way. Her master's heart smote him when he saw what she had suffered and effected: but she was nothing daunted; and having deposited her young 
one in a place of safety, she again set out full speed to the hills, and brought another and another, till she removed her whole litter one by one; but the last one was dead. The stories related of the dogs of sheep-stealers, he continues, are fairly beyond all credibility. I cannot attach credit to some of them without believing the animals to have been devils incarnate, come to the earth for the destruction both of the souls and bodies of men. I cannot mention names, for the sake of families that still remain in the country; but there have been sundry men executed, who belonged to this district of the kingdom, for that heinous crime, in my own days; and others have absconded, just in time to save their necks. There was not one of these to whom I allude who did not acknowledge his dog to be the greatest aggressor. One young man in particular, who was, I believe, overtaken by justice for his first offence, stated, that after he had folded the sheep by moonlight, and selected his number from the flock of a former master, he took them out, and set away with them towards Edinburgh. But before he had got them quite off the farm, his conscience smote him, as he said (but more likely a dread of that which soon followed), and he quitted the sheep, letting them go again to the hill. He called his dog off them; and mounting his pony, he rode away. At that time he said his dog was capering and playing around him, as if glad of having got free of a troublesome business; and he regarded him no more, till, after having rode about three miles, he thought again and again that he heard something coming up behind him. Halting, at length, to ascertain what it was, in a few minutes up came his dog with the stolen animals, driving them at a furious rate to keep up with his master. The sheep were all smoking, and hanging out their tongues, and their guide was fully warm as they. The young man was now exceedingly troubled, for the sheep having been brought so far from home, he dreaded there would be a pursuit, and he could not get them home again 
before day. Resolving, at all events, to keep his hands clear of them, he corrected his dog in great wrath, left the sheep once more, and taking colley with him, rode off a second time. He had not ridden above a mile, till he perceived that his assistant had again given him the slip; and suspecting for what purpose, he was terribly alarmed as well as chagrined; for daylight now approached, and he durst not make a noise calling on his dog, for fear of alarming the neighbourhood, in a place where they were both well known. He resolved therefore to abandon the animal to himself, and take a road across the country which he was sure the other did not know, and could not follow. He took that road; but being on horseback, he sould not get across the enclosed fields. He at length came to a gate, which he shut behind him, and went about half a mile farther, by a zigzag course, to a farm-house where both his sister and sweetheart lived; and at that place he remained until after breakfast time. The people of this house were all examined on the trial, and no one had either seen the sheep or heard them mentioned, save one man, who came up to the aggressor as he was standing at the stable-door, and told him that his dog had the sheep safe enough down at the Crooked Yett, and he needed not hurry himself. $\mathrm{He}$ answered, that the sheep were not histhey were young Mr. Thomson's, who had left them to his charge, and he was in search of a man to drive them, which made him come off his road." The fidelity of this animal cost his master his life.

The st.

The St. Bernard Dog always honoured for Bernard Dog. his work's sake, resembles the Newfoundland in form, hair, colour, and size. "There is another race," says Colonel Smith, "trained to the same service, with close short hair, and more or less marked with grey, liver colour and black clouds." Bass, a famous St. Bernard, the property of Sir Thomas Dick Lauder, is thus described by him in a letter to Mr. W. H. Lizars printed in Vol. XIX of "The 
Naturalist's Library":- "My St. Bernard was brought home direct from the Great St. Bernard, when he was a puppy of about four or five months. His bark is tremendous; so loud, indeed, that I have often distinguished it nearly a mile off. He had been missing for some time, when, to my great joy, one of the letter-carriers brought him back; and the man's account was, that in going along a certain street, he heard his bark from the inside of a yard, and knew it immediately. He knocked at the gate, and said to the owner of the premises, 'You have got Sir Thomas Lauder's big dog.' The man denied it. 'But I know you have,' continued the letter-carrier; 'I can swear that I heard the bark of Sir Thomas's big dog; for there is no dog in or about all Edinburgh that has such a bark.' At last, with great reluctance, the man gave up the dog to the letter-carrier, who brought him home here. But though Bass's bark is so terrific, he is the best-natured and most playful dog I ever saw; so much so, indeed, that the small King Charles's spaniel, Raith, used to tyrannize over him for many months after he came here from abroad. I have seen the little creature run furiously at the great animal when gnawing a bone, who instantly turned himself submissively over on his back, with all his legs in the air, whilst Raith, seizing the bone, would make the most absurd and unavailing attempts to bestride the enormous head of his subdued companion, with the most ludicrous affectation of the terrible growling, that might bespeak the loftiest description of dog-indignation. When a dog attacks Bass in the street or road, he runs away rather than quarrel; but when compelled to fight by any perseverance in the attacking party, he throws his enemy down in a moment, and then, without biting him, he lays his whole immense bulk down upon him, till he nearly smothers him. He took a particular fancy for one of the postmen who deliver letters here, whose duty it was, besides delivering letters, to carry a letter bag from one receiving-house to 
another, and this bag he used to give Bass to carry. Bass always followed that man through all the villas in this neighbourhood where he had deliveries to make, and he invariably parted with him opposite to the gate of the Convent of St. Margaret's, and returned home. When our gate was shut here to prevent his following the postman, the dog always leaped a high wall to get after him. One day when the postman was ill, or detained by some accidental circumstance, he sent a man in his place. Bass went up to the man, curiously scanning his face, whilst the man rather retired from the dog, by no means liking his appearance. But as the man left the place, Bass followed him, showing strong symptoms that he was determined to have the post-bag. The man did all he could to keep possession of it. But at length Bass seeing that he had no chance of getting possession of the bag by civil entreaty, raised himself up on his hind-legs, and putting a great forepaw on each of the man's shoulders, he laid him flat on his back in the road, and quietly picking up the bag, he proceeded peaceably on his wonted way. The man, much dismayed, arose and followed the dog, making every now and then an ineffectual attempt to coax him to give up the bag. At the first house he came to, he told his fears, and the dilemma he was in; but the people comforted him, by telling him that the dog always carried the bag. Bass walked with the man to all the houses at which he delivered letters, and along the road till he came to the gate of St. Margaret's, where he dropped the bag and returned home."

The St. Bernard "The convent of the Great St. Bernard is at Work. situated near the top of the mountain known by that name, near one of the most dangerous passages of the Alps, between Switzerland and Savoy. In these regions the traveller is often overtaken by the most severe weather, even after days of cloudless beauty, when the glaciers glitter in the sunshine, and the pink flowers of the rhododendron 
appear as if they were never to be sullied by the tempest. But a storm suddenly comes on; the roads are rendered impassable by drifts of snow; the avalanches, which are huge loosened masses of snow or ice, are swept into the valleys, carrying trees and crags of rock before them. Benumbed with cold, weary in the search for a lost track, his senses yielding to the stupifying influence of frost which betrays the exhausted sufferer into a deep sleep, the unhappy man sinks upon the ground, and the snow-drift covers him from human sight. It is then that the keen scent and the exquisite docility of these admirable dogs are called into action. Though the perishing man lie ten or even twelve feet beneath the snow, the delicacy of smell with which they can trace him offers a chance of escape. They scratch away the snow with their feet; they set up a continued hoarse and solemn bark, which brings the monks and labourers of the convent to their assistance. To provide for the chance that the dogs, without human help, may succeed in discovering the unfortunate traveller, one of them has a flask of spirits round his neck, to which the fainting man may apply for support; and another has a cloak to cover him. These wonderful exertions are often successful; and even where they fail of restoring him who has perished, the dogs discover the body, so that it may be secured for the recognition of friends; and such is the effect of the temperature, that the dead features generally preserve their firmness for the space of two years." One of these dogs is said to have saved as many as forty lives and finally to have fallen a victim to an avalanche.

The Greyhound. The Greyhound is characterised by elegance of form and grace of movement; he has also great powers of speed and endurance, is mild and affectionate in disposition and sagacious in matters other than those connected with the chase. "The narrow, sharp head, the light half hanging ears, the Iong neck, the arched back, the slender yet sinewy limbs, the deep chest, showing the high development of the 
breathing organs, and the elevated hind quarters, says Mrs. Bowdich, all shadow forth the peculiar qualities of these dogs. Their coat has been adapted to the climate in which they originally lived: here it is smooth; but becomes more shaggy as they are from colder regions." "The Scotch Greyhound (Canis Scoticus)," she continues, "generally white, with black clouds, is said to be the most intellectual of all, and formerly to have had so good a scent as to be employed as a bloodhound. Maida, whose name is immortalized as the favourite of Sir Walter Scott, was a Scottish greyhound. The Irish is the largest of all the western breeds, and is supposed to owe this distinction to mingling with the great Danish dog. To it Ireland owes the extirpation of wolves, though it now scarcely exists itself but in name."

The greyhound is now principally bred for sporting purposes, coursing being the favourite amusement. The great speed and endurance of the dog is shown in this pastime. Mr. Jesse records several instances of dogs who have died from exhaustion rather than give up the chase, in one of which it is stated that two dogs and a hare were found dead within a few yards of each other after a run of several miles. Mr. Daniel in his rural sports gives an instance in which a brace of greyhounds chased a hare a distance of four miles in twelve minutes.

The Greyhound's Washington Irving tells the following story Affection. of a greyhound's affection for his master. "An officer named St. Leger, who was imprisoned in Vincennes (near Paris) during the wars of St. Bartholomew, wished to keep with him a greyhound that he had brought up, and which was much attached to him; but they harshly refused him this innocent pleasure, and sent away the greyhound to his house in the Rue des Lions Saint Paul. The next day the greyhound returned alone to Vincennes, and began to bark under the windows of the tower, where the officer was confined. St. Leger approached, looked through the bars, 
and was delighted again to see his faithful hound, who began to jump and play a thousand gambols to show her joy. He threw a piece of bread to the animal, who ate it with great good will; and, in spite of the immense wall which separated them, they breakfasted together like two friends. This friendly visit was not the last. Abandoned by his relations, who believed him dead, the unfortunate prisoner received the visits of his greyhound only, during four years' confinement. Whatever weather it might be, in spite of rain or snow, the faithful animal did not fail a single day to pay her accustomed visit. Six months after his release from prison St. Leger died. The faithful greyhound would no longer remain in the house; but on the day after the funeral returned to the castle of Vincennes, and it is supposed she was actuated by a motive of gratitude. A jailor of the outer court had always shown great kindness to this dog, which was as handsome as affectionate. Contrary to the custom of people of that class, this man had been touched by her attachment and beauty, so that he facilitated her approach to see her master, and also insured her a safe retreat. Penetrated with gratitude for this service, the greyhound remained the rest of her life near the benevolent jailor. It was remarked, that even while testifying her zeal and gratitude for her second master, one could easily see that her heart was with the first. Like those who, having lost a parent, a brother, or a friend, come from afar to seek consolation by viewing the place which they inhabited, this affectionate animal repaired frequently to the tower where St. Leger had been imprisoned, and would contemplate for hours together the gloomy window from which her dear master had so often smiled to her, and where they had so frequently breakfasted together."

The Lurcher. "The rough, large-boned, ill-looking Lurcher," says Mrs. Bowdich, "is said to have descended from the rough greyhound and the shepherd's dog. It is now rare; 
but there are some of its sinister-looking mongrel progeny still to be seen. They always bear the reputation of being poachers' dogs, and are deeply attached to their owners. They have a fine scent; and a man confessed to Mr. Bewick, that he could, with a pair of lurchers, procure as many rabbits as he pleased. They never give tongue, but set about their work silently and cautiously, and hunt hares and partridges, driving the latter into the nets of the unlawful sportsmen." $\mathrm{He}$ is a dog to whom a bad name has been given, and who has found a bad name but one step from hanging.

The Blood- The Bloodhound (Canis Sanguinarius) whether hound. because less needed now than formally or not, is less cultivated and is therefore more rare. Mr. Bell's description of the breed is as follows:- "They stand twentyeight inches high at the shoulder; the muzzle broad and full; the upper lip large and pendulous; the vertex of the head protuberant; the expression stern, thoughtful, and noble; the breast broad; the limbs strong and muscular; and the original colour a deep tan, with large black clouds. They are silent when following their scent; and in this respect differ from other hounds, who are generally gifted with fine deep voices. Numbers, under the name of sleuth-hounds, used to be kept on the Borders; and kings and troopers, perhaps equally marauders, have in olden times found it difficult to evade them. The noble Bruce had several narrow escapes from them; and the only sure way to destroy their scent was to spill blood upon the track. In all the common routine of life they are good-natured and intelligent, and make excellent watch-dogs. A story is related of a nobleman, who, to make a trial whether a young hound was well instructed, desired one of his servants to walk to a town four miles off, and then to a market town three miles from thence. The dog, without seeing the man he was to pursue, followed him by the scent to the above- 
mentioned places, notwithstanding the multitude of marketpeople that went along the same road, and of travellers that had occasion to come; and when the bloodhound came to the market town, he passed through the streets without taking notice of any of the people there, and ceased not till he had gone to the house where the man he sought rested himself, and where he found him in an upper room, to the wonder of those who had accompanied him in this pursuit."

The scent A strong characteristic of the Bloodhound is of the of course his remarkable scent for blood. Bloodhound. "Bloodhounds," says Bingley, "were formerly used in certain districts lying between England and Scotland, that were much infested by robbers and murderers; and a tax was laid on the inhabitants for keeping and maintaining a certain number of these animals. Some few are yet kept in the northern parts of the kingdom, and in the lodges of the royal forests, where they are used in pursuit of deer that have been previously wounded. They are also sometimes employed in discovering deer-stealers, whom they infallibly trace by the blood that issues from the wounds of their victims. A very extraordinary instance of this occurred in the New Forest, in the year 1810, and was related to me by the Right Hon. G. H. Rose. A person, in getting over a stile into a field near the Forest, remarked that there was blood upon it. Immediately afterwards he recollected that some deer had been killed, and several sheep stolen in the neighbourhood; and that this might possibly be the blood of one that had been killed in the preceding night. The man went to the nearest lodge to give information; but the keeper being from home, he was under the necessity of going to Rhinefield Lodge, which was at a considerable distance. Toomer, the under-keeper, went with him to the place, accompanied by a bloodhound. The dog, when brought to the spot, was laid on the scent; 
and after following for about a mile the track which the depredator had taken, he came at last to a heap of furze fagots belonging to the family of a cottager. The woman of the house attempted to drive the dog away, but was prevented; and on the fagots being removed a hole was discovered in the ground, which contained the body of a sheep that had recently been killed, and also a considerable quantity of salted meat. The circumstance which renders this account the more remarkable is, that the dog was not brought to the scent until more than sixteen hours had elapsed after the man had carried away the sheep."

The Stag- "The stag hound," says Colonel Smith, "was a

Hound. large stately animal, equal or little less than the blood hound, and originally, like that race, slow, sure, cautious and steady." "The modern hound is perhaps still handsomer, though somewhat smaller; and the breed having been crossed with the fox hound is now much faster." The stag hunt having declined in public favour they have ceased to be bred in packs for hunting purposes.

A stag- "Many years since," says Captain Brown, "a very

Hunt. large stag was turned out of Whinfield Park in the county of Westmoreland, and was pursued by the hounds till, by accident or fatigue, the whole pack was thrown out with the exception of two dogs which continued the chase. Its length is uncertain, but the chase was seen at Red Kirk near Annan in Scotland, distant by the post road about fortysix miles. The stag returned to the park from which he had set out, so that considering the circuitous route which it pursued, it is supposed to have run over not less than one hundred and twenty miles. It was its greatest and last achievement, for it leapt the wall of the park and immediately expired; the hounds were also found dead at no great distance from the wall which they had been unable to leap. An inscription was placed on a tree in the park, in memory of the animals, and the horns of the stag, the largest ever 
seen in that part of the country, were placed over it." The Fox- "In giving a description of the various breeds of Hound. dogs," says Mr. Jesse, "everyone must be aware, that by crossing and recrossing them many of those we now see have but little claim to originality. The fox-hound, the old Irish wolf-dog, and the Colley or shepherd's dog, may perhaps be considered as possessing the greatest purity of blood." Mr. Jesse then refers to a picture of a pack of hounds in Wilkinson's "Manners and Customs of the Egyptians," a picture which was copied from a painting found in one of the tombs of the Pharaohs, in which "every individual hound is characteristic of the present breed." If this be so, as Mr. Jesse says, "this breed must be considered of a much more ancient date than is generally supposed." The Fox-hound is described by Colonel Smith as "somewhat lower at the shoulders and more slenderly built" than the stag-hound. His colour is "white, but commonly marked with larger clouds of black and $\tan$, one on each side the head, covering the ears, the same on each flank and one at the root of the tail." The Fox-hound has great strength and endurance, and will run ten hours in pursuit of the fox.

The Fox-hound's Many extraordinary stories are told of the Tenacity. Fox-hound's ardour for sport. According to Mr. Jesse, a bitch was on one occasion taken in labour while in the hunting field, and after giving birth to a pup took it in its mouth and pursued the chase. Another bitch, whose eye had been struck from the socket accidentally by the lash of the whipper-in who did not believe her challenge, pursued the fox alone for a great distance with her eye pendant, until the rest of the pack came up and the fox was killed. Perhaps one of the most remarkable instances of tenacity of purpose in an animal is that quoted by Mr. Jesse from the supplement to Mr. Daniel's "Rural Sports." "The circumstance took place in the year 1808 , in the counties of Inverness and Perth, and perhaps surpasses any length of 
pursuit known in the annals of hunting. On the 8th of June in that year, a fox and hound were seen near Dunkeld in Perthshire, on the high road, proceeding at a slow trotting pace. The dog was about fifty yards behind the fox, and each was so fatigued as not to gain on the other. A countryman very easily caught the fox, and both it and the dog were taken to a gentleman's house in the neighbourhood, where the fox died. It was afterwards ascertained that the hound belonged to the Duke of Gordon, and that the fox was started on the morning of the $4^{\text {th }}$ of June, on the top of those hills called Monaliadh, which separate Badenoch from Fort Augustus. From this it appeared that the chase lasted four days, and that the distance traversed from the place where the fox was unkennelled to the spot where it was caught, without making any allowances for doubles, crosses, etc., and as the crow flies, exceeded seventy miles."

The Harrier. "The Harrier," says Colonel Smith, "so called from being usually applied to hare hunting is smaller than the fox-hound, not exceeding eighteen inches at the shoulder. It is entirely an artificial breed and is often confounded with the beagle."

The Beagle. The Beagle is called by Mr. Jesse, "a Foxhound in miniature," and he adds nothing can well be more perfect than the shape of these small dogs. "In Queen Elizabeth's reign," says Colonel Smith, "the fanciers bred a race so small, that a complete cry of them could be carried out to the field in a pair of panniers. That princess had little singing beagles which could be placed in a man's glove! At present they are about twelve or fourteen inches at the shoulders, stout and compact in make, with long ears, and either marked with a bright streak or spot of white about the neck on a dark brown coat, or white with spots like a harrier, of black and red. They are slow but persevering, and are sufficiently sure of killing their game." 
The Dalmatian Colonel Smith places the Dalmatian dog Dog. with the hounds on the ground of similarity of general structure. Elegant in form and beautiful in making it is said to be less keen in scent and less sagacious than other dogs. Sagacious or not, it was one of these dogs that Lord Maynard found awaiting him at his house in England after having lost him in France.

The Turnspit. "The Turnspit," says Captain Brown, "derived its name from the service in which it was engaged before the invention of machinery to do the same work, and, what is remarkable, now that the office is extinct, so also has nearly become the species which used to perform it." "I have now in my kitchen," said the Duke de Laincourt, to M. Descartes, "two turnspits which take their turns regularly every other day in the wheel: one of them, not liking his employment, hid himself on the day he should have wrought, when his companion was forced to mount the wheel in his stead; but crying and wagging his tail, he intimated that those in attendance should first follow him. He immediately conducted them to a garret, where he dislodged the idle dog, and killed him immediately." Another instance is recorded by Captain Brown as follows: "When the cook had prepared the meat for roasting, he found that the dog which should have wrought the spit had disappeared. He attempted to employ another, but it bit his leg and fled. Soon after, however, the refractory dog entered the kitchen driving before him the truant turnspit, which immediately of its own accord went into the wheel." It is easy to see from these stories that the occupation was not a popular one and it is well that it is no longer a necessary one.

The Pointer. The pointer (Canis avicularis) as resembling the race of hounds, more than any other of the shooting or gun dogs is placed next to them in the classification of Colonel Smith, who says: "In their present qualities of standing fixed and pointing to game, we see the result of a 
long course of severe training; and it is a curious fact, that by a succession of generations having been constantly educated to this purpose, it has become almost innate, and young dogs of the true breed point with scarcely any instruction: this habit is so firm in some that the late Mr. Gilpin is reported to have painted a brace of pointers while in the act, and that they stood an hour and a quarter without moving." A smooth dog, resembling the fox-hound in his markings, though sometimes entirely black, the pointer is used by sportsmen to point them to the spot where the game is to be found. "It ranges the fields," says Mr. Wood, "until it scents the hare or partridge lying close on the ground. It then remains still as if carved in stone, every limb fixed, and the tail pointing straight behind it. In this attitude it remains until the gun is discharged, reloaded, and the sportsman has reached the place where the bird sprang."

The Pointer as The pointer is a keen sportsman and will

a Sportsman. "point" without tiring while worthily supported by the gun, but many stories are told of his disgust at a bad shot and his refusal to "point" for unskilful sportsmen. The following amusing story is told by Captain Brown and is quoted as follows by Mr. Jesse: "A gentleman, on his requesting the loan of a pointer-dog from a friend, was informed by him that the dog would behave very well so long as he could kill his birds; but if he frequently missed them, it would run home and leave him. The dog was sent, and the following day was fixed for trial; but, unfortunately, his new master was a remarkably bad shot. Bird after bird rose and was fired at, but still pursued its flight untouched, till, at last, the pointer became careless, and often missed his game. As if seemingly willing, however, to give one chance more, he made a dead stop at a fern-bush, with his nose pointed downward, the fore-foot bent, and his tail straight and steady. In this position he remained firm till the sportsman was close to him, with both barrels cocked, then mov- 
ing steadily forward for a few paces, he at last stood still near a bunch of heather, the tail expressing the anxiety of the mir d by moving regularly backwards and forwards. At last out sprang a fine old blackcock. Bang, bang, went both barrels, but the bird escaped unhurt. The patience of the dog was now quite exhausted; and, instead of dropping to charge, he turned boldly round, placed his tail between his legs, gave one howl, long and loud, and set off as fast as he could to his own home." The pointer has been known to lie down without bidding beside game which has been dropped from a bag, after a long day's shooting, and watch it faithfully until relieved on the following day, when the missing birds were searched for and found.

The Setter. The Setter (Canis Index) divides with the pointer the duty of attending the sportsman on his shooting expeditions. According to Captain Brown he was "originally derived from a cross between the Spanish pointer and the large water spaniel and was justly celebrated for his fine scent." Many crossings have considerably varied the breed, of which the Irish is now considered purer than the English and Scotch breeds. "In figure," says Colonel Smith, "they participate of the pointer and the Spaniel, though larger than the latter. In England they are white, or white with black or brown marks." They are intelligent, affectionate and docile, and often show great sagacity outside the domain of sport.

The scent of Col. Hutchinson says, "I was partridge-shooting the Setter. the season before last with an intimate friend. The air was soft, and there was a good breeze. We came upon a large turnip-field, deeply trenched on account of its damp situation. A white setter, that habitually carried a lofty head, drew for awhile, and then came to a point. We got up to her. She led us across some ridges, when her companion, a jealous dog (a pointer), which had at first backed correctly, most improperly pushed on in front, but, 
not being able to acknowledge the scent, went off, clearly imagining the bitch was in error. She, however, held on, and in beautiful style brought us up direct to a covey. My friend and I agreed that she must have been but little, if at all, less than one hundred yards off when she first winded the birds; and it was clear to us that they could not have been running, for the breeze came directly across the furrows, and she had led us in the wind's eye. We thought the point the more remarkable, as it is generally supposed that the strong smell of turnips diminishes a dog's power of scenting birds."

The Setter's Mr. Huet tells the following story of the sagacity

sagacity. of the setter. "The gamekeeper had, on one of the short days of December, shot at and wounded a deer. Hoping to run him down before night, he instantly put the dog upon the track, which followed it at full speed, and soon was out of sight. At length it grew dark, and the gamekeeper returned home, thinking he should find the setter arrived there before him; but he was disappointed, and became apprehensive that his dog might have lost himself, or fallen a prey to some ravenous animal. The next morning, however, we were all greatly rejoiced to see him come running into the yard, whence he directly hastened to the door of my apartment, and, on being admitted, ran, with gestures expressive of solicitude and eagerness, to a corner of the room where guns were placed. We understood the hint, and, taking the guns, followed him. He led us not by the road which he himself had taken out of the wood, but by beaten paths half round it, and then by several wood-cutters' tracks in different directions, to a thicket, where, following him a few paces, we found the deer which he had killed. The dog seems to have rightly judged that we should have been obliged to nake our way with much difficulty through almost the whole length of the wood, in order to come to the deer in a straight direction, and he therefore led us a circuitcus but 
open and convenient road. Between the legs of the deer, which he had guarded during the night against the beasts of prey that might otherwise have seized upon it, he had scratched a hole in the snow, and filled it with dry leaves for his bed. The extraordinary sagacity which he had displayed upon this occasion rendered him doubly valuable to us, and it therefore caused us very serious regret when, in the ensuing summer, the poor animal went mad, possibly in consequence of his exposure to the severe frost of that night, and it became necessary for the gamekeeper to shoot him, which he could not do without shedding tears. He said he would willingly have given his best cow to save him; and I confess myself that I would not have hesitated to part with my best horse upon the same terms."

The Spaniel. There are many varieties of the Spaniel of which the Water Spaniel, the King Charles Spaniel, the Blenheim and the Maltese Spaniels are the best known. The Water Spaniels figure on some of the later monuments of Rome and so prove their antiquity. Colonel Smith describes the Spaniel as a small setter, with silky hair and fine long villous ears; black, brown pied, liver coloured, white and blackand-white, the water spaniel differing from the other species chiefly in his readiness to hunt and swim in the water and the hair being somewhat harder to the touch. The spaniel has a great affection for his master and is never tired of testifying his appreciation of his kindness. Colonel Smith mentions a dog allied to the spaniel race, who at the time of his writing (April 1840) had been lying on the grave of his mistress for three days, refusing all food, and was on that day being forcibly removed. Spaniels are often very intelligent, displaying the same sagacity as other and larger dogs and in the same way. Mr. Jesse mentions a King Charles spaniel who was locked by his master in a room in Vere St. Clare Market, one afternoon about half past five, while he went with his family to Drury Lane theatre. About eight 
o'clock in the evening the dog escaped his confinement and found his way to the theatre where he discovered his master in the midst of the pit, though it was crowded at the time. The Blenheim spaniel is similar to the King Charles breed, though somewhat different in its markings, fuller about the muzzle and shorter in the back. Blenheims have been known to show great intelligence and affection. A story is told of one who upon being attacked by two cats, obtained the assistance of a third cat, waylaid his enemies one at a time and, with the assistance of his friend, taught them better manners. The Maltese dog is another favourite species, much admired and petted by ladies.

The sagacity Captain Brown gives the following from a letter of the Water written by a gentleman at Dijon in France, to Bpaniel his friend in London, dated August 15, I764:

"Since my arrival here a man has been broken on the wheel, with no other proof to condemn him than that of a water-spaniel. The circumstances attending it being so very singular and striking, I beg leave to communicate them to you. A farmer, who had been to receive a sum of money, was waylaid, robbed, and murdered, by two villains. The farmer's dog returned with all speed to the house of the person who had paid the money, and expressed such amazing anxiety that he would follow him, pulling him several times by the sleeve and skirt of the coat, that, at length, the gentleman yielded to his importunity. The dog led him to the field, a little from the roadside, where the body lay. From thence the gentleman went to a public-house, in order to alarm the country. The moment he entered, (as the two villains were there drinking), the dog seized the murderer by the throat, and the other made his escape. This man lay in prison three months, during which time they visited him once a-week with the spaniel, and though they made him change his clothes with other prisoners, and always stand in the midst of a crowd, yet did the animal always find him 
out, and fly at him. On the day of trial, when the prisoner was at the bar, the dog was let loose in the court-house, and in the midst of some hundreds he found him out (though dressed entirely in new clothes), and would have torn him to pieces had he been allowed; in consequence of which he was condemned, and at the place of execution he confessed the fact."

The Terrier. There are many varieties of terrier including numerous celebrated breeds. The English, Scotch, Skye, Bull and Fox terriers being the best known. Innumerable stories of the intelligence and sagacity of the various breeds might be told if space permitted, but it must suffice to say that for sportsmanlike qualities, for general intelligence and sagacity, and for affection for his master, the terrier of whatever breed will hold his own against any other dog. Dogs are said to have natural antipathies, and that of the Bull-dog for the bull is an obvious illustration. An equal antipathy is shown by the English terrier for the rat and by the Fox-terrier for the cat, though the latter is perhaps as much a matter of education as of nature. Terriers are, however, among the best known of dogs and therefore need the less description.

The Mastiff. The Mastiff is said to be of an original breed indigenous to England, whence some were exported to Italy in the days of the Roman emperors. The breed has since been crossed by stag and blood hounds and the present is a magnificent animal of great power and noble character. The ancient breed was brindled yellow and black, the present is usually deeper or lighter buff with dark muzzle and cars. The mastiff is sometimes twenty-nine or thirty inches in height at the shoulder.

The Mastiff's The Mastiff is the best of watch dogs, for he

Fidelity. brings an intelligence to bear upon his duty which is in the highest degree surprising. He has been known to walk by the -side of an intending thief "forbidding his laying hands upon any article, yet abstaining 


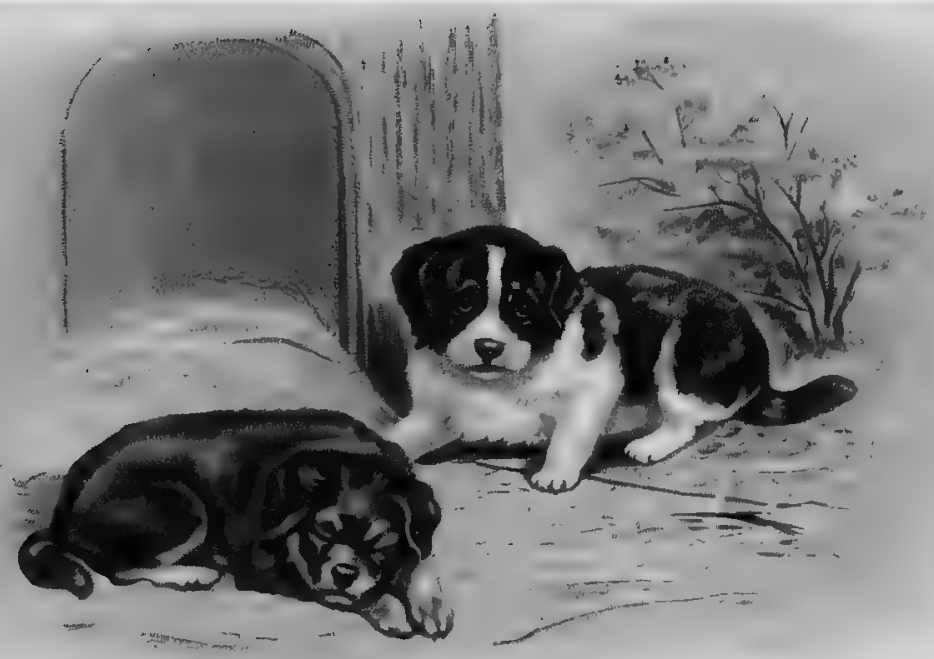

PUPPIES

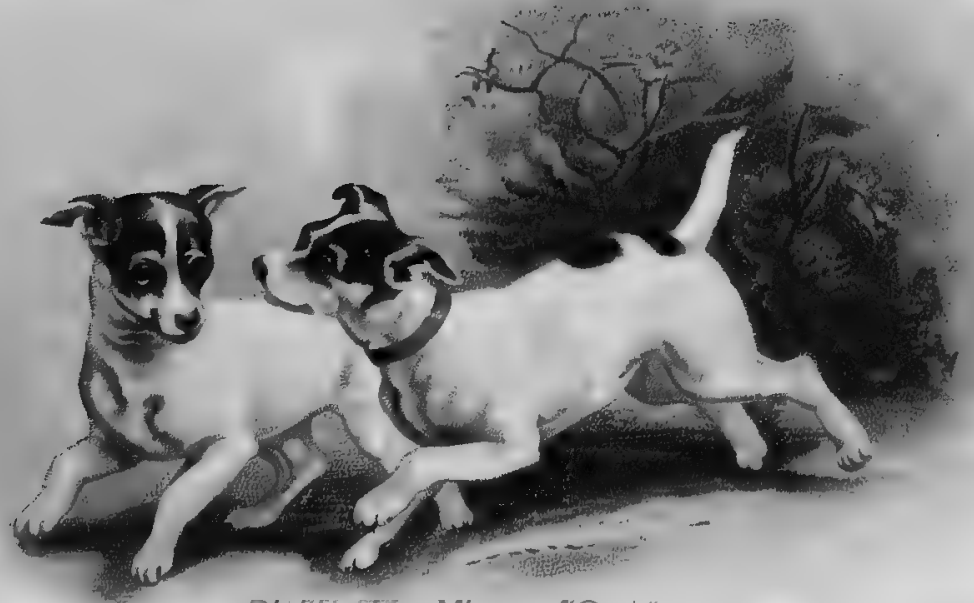

Digitiżed by Microsoft@ 
Digitized by Microsofte 
from doing him any bodily harm, and suffering his escape over the walls," but leaving his master's property intact. A mastiff who had been left by his master, who was a sweep, in charge of his bag of soot in a narrow street in Southampton, refused to leave it either for coaxings or threats, and rather than desert his duty allowed himself to be run over and killed. The Mastiff's The mastiff has a powerful scent, and remarkDiscrimina- able skill in discovering the lost property of his tion. master. Captain Brown gives the following extract from a letter from St. Germains: "An English gentleman some time ago came to our Vauxhall with a large mastiff, which was refused admittance, and the gentleman left him in the care of the body-guards, who are placed there. The Englishman, some time after he had entered, returned to the gate and informed the guards that he had lost his watch, telling the sergeant, that if he would permit him to take in the dog, he would soon discover the thief. "His request being granted, the gentleman made motions to the dog of what he had lost, which immediately ran about amongst the company, and traversed the gardens, till at last he laid hold of a man. The gentleman insisted that this person had got his watch; and on being searched, not only his watch, but six others, were discovered in his pockets. What is more remarkable, the dog possessed such a perfection of instinct as to take his master's watch from the other six, and carry it to him."

The Mastiff Mr. Jesse gives the following story which he as Protector. reprinted from a contemporary newspaper:

"A most extraordinary circumstance has just occurred at the Hawick toll-bar, which is kept by two old women. It appears that they had a sum of money in the house, and were extremely alarmed lest they should be robbed of it. Their fears prevailed to such an extent, that, when a carrier whom they knew was passing by, they urgently requested him to remain with them all night, which, however, his duties 
would not permit him to do; but, in consideration of the alarm of the women, he consented to leave with them a large mastiff dog. In the night the women were disturbed by the uneasiness of the dog, and heard a noise apparently like an attempt to force an entrance into the premises, upon which they escaped by the back-door, and ran to a neighbouring house, which happened to be a blacksmith's shop. They knocked at the door, and were answered from within by the smith's wife. She said her husband was absent, but that she was willing to accompany the terrified women to their home. On reaching the house, they heard a savage but half-stifled growling from the dog. On entering they saw the body of a man hanging half in and half out of their little window, whom the dog had seized by the throat, and was still worrying. On examination, the man proved to be their neighbour the blacksmith, dreadfully torn about the throat, and quite dead."

The Bull- The Bull-dog (Canis Anglicus), is said to be Dog. an original English breed, and Colonel Smith suggests that this dog rather than the mastiff was the one which flourished in England in Roman times. Not indeed the breed as it at present exists, but "one little inferior to the mastiff," "but with the peculiar features of the bull form more strongly marked." "The bull-dog," says Colonel Smith, "differs from all others, even from the mastiff, in giving no warning of his attack by his barking, he grapples his opponents without in the least estimating their comparative weight and powers. We have seen one pinning an American Bison and holding his nose down till the animal gradually brought forward its hind feet and crushing the dog to death tore his muzzle out of the fangs, most dreadfully mangled. We have known another hallooed on to attack a disabled eagle; the bird unable to escape, threw himself on the back, and as the dog sprang at his throat, struck him with his claws, one of which penetrating the skull, killed him instantly, and caused. 
his master the loss of a valued animal and one hundred dollars in the wager." "The bull-dog is possessed of less sagacity and less attachment than any of the hound tribe; he is therefore less favoured, and more rarely bred with care, excepting by professed amateurs of sports and feelings little creditable to humanity. $\mathrm{He}$ is of moderate size, but entirely moulded for strength and elasticity." $\mathrm{He}$ never leaves his hold, when once he has got it, while life lasts, hence he has become the type of obstinate pertinacity; and unflinching courage.

The Poodle The Poodle dog while possessing many natural

Dog. qualities which endear it to its owner, is capable of great cultivation and is for this reason much affected by those who train dogs for public performances. Of the clever tricks the poodle has been trained to perform many stories are told, among which the following from M. Blaze's "History of the Dog," as quoted in Mr. Jesse's "Anecdotes of Dogs," is one of the most amusing.

"A shoe-black on the Pont Neuf at Paris had a poodle dog, whose sagacity brought no small profit to his master. If the dog saw a person with well-polished boots go across the bridge, he contrived to dirty them, by having first rolled himself in the mud of the Seine. His master was then employed to clean them. An English gentleman, who had suffered more than once from the annoyance of having his boots dirtied by a dog, was at last induced to watch his proceedings, and thus detected the tricks he was playing for his master's benefit. He was so much pleased with the animal's sagacity, that he purchased him at a high price and conveyed him to London. On arriving there, he was confined to the house till he appeared perfectly satisfied with his new master and his new situation. He at last, however, contrived to escape, and made his way back to Paris, where he rejoined his old master, and resumed his former occupation." 
Weasels,

We come next to the family of the Mustelidæ Otters and which includes Weasels, Otters and Badgers, which Badgers. we take as the heads of the three sub-families into which it is divided. The first of these includes the Pine Marten, occasionally found in Ireland and Scotland but more commonly in different parts of Europe; the Sable, which belongs to northern Europe and Asia; the American Sable, which supplies the English market with hundreds of thousands of skins annually; the Ermine or Stoat, still to be found in Great-Britain and familiar in the northern parts of Europe, Africa and America; the Weasel which has much the same locale as the Ermine; the Ferret which hails from Africa and which is cultivated in England for its use in the destruction of vermin; and the Glutton (Gulo luscus) which is found principally in North America. The Polecat is also a member of this family. It is about seventeen inches long and in form resembles the weasel. Its colour is deep chocolate. It generally lives in the neighbourhood of houses on hares, rabbits, and birds. When pinched for food it will also catch and eat fish. It is remarkable for an insufferably fetid odour.

The weasel. The weasel though thought by some to be incapable of domestication has, like most other animals who have had the chance, shown itselt amenable to kindly treatment. Mdlle. de Laistre possessed one which she kept in her chamber, dispelling its strong odours by perfumes. This weasel displayed towards her extravagant evidence of affection. "If the servant sets it at liberty before $I$ am up in the morning," she writes, "after a thousand gambols, it comes into my bed, and reposes in my hand or on my bosom. If I am up before it is let out, it will fly to me in rapture, and spend half an hour in caressing me. The curiosity of this little pet is unbounded, for it is impossible to open a drawer or box, without its roving through every part of it; if even a piece of paper or a book is looked at, it will also examine 
it with attention." This weasel lived on friendly terms with both a cat and a dog who shared his mistress' favours. That the weasel can defend himself when attacked is shown by the following incident told by Mr. Bell: "As a gentleman was riding over his grounds, he saw, at a short distance from him, a kite pounce on some object on the ground, and rise with it in his talons. In a few moments, however, the kite began to show signs of great uneasiness, rising rapidly in the air, or as quickly falling, and wheeling irregularly round, whilst evidently endeavouring to free himself from some obnoxious thing with his feet. After a short but sharp contest, the kite fell suddenly to the earth. The gentleman instantly rode up to the spot, when a weasel ran away from the kite, apparently unhurt, leaving the bird dead, with a hole eaten through the skin under the wing, and the large blood-vessels of the part torn through." The length of the common weasel is about eight inches.

The Common There are several genera of Otters. The common

Otter. otter (Lutra vulgaris) is known throughout Europe and is not uncommon in Great Britain. The otter lives on fish, for the hunting of which he is admirably fitted. He is web-footed and has a body of great flexibility and short but remarkably muscular legs. The Otter was looked upon as a friend by the peasants living near salmon preserves years ago, for after landing his prey he was content with but a small portion for himself, and left the rest which the peasants readily appropriated.

"Otters," says Mr. St. John, "are very affectionate animals; the young anxiously seek their mother if she should be killed; and if the young are injured, the parent hovers near them till she is herself destroyed. If one of a pair be killed, the one that is left will hunt for its mate with untiring perseverance; and if one be caught in a trap, its companion will run round and round, endeavouring to set it free, on which occasions, though so quiet at other times, they make a snorting and blowing like a horse." 
"A labourer going to his work, soon after five o'clock in the morning, saw a number of animals coming towards him, and stood quietly by the hedge till they came alongside of him. He then perceived four old otters, probably dams, and about twenty young ones. He took a stick out of the hedge and killed one. Directly it began to squeak, all the four old ones turned back, and stood till the other young ones had escaped through the hedge, and then went quietly themselves. Several families were thus journeying together, and probably they had left their former abode from not finding a sufficiency of food." Otters have often been tamed and taught to catch fish for their masters. Captain Brown tells of an otter which was caught when young and trained by James Campbell near Inverness. "It was frequently employed in catching fish, and would, sometimes, take eight or ten salmon in a day. If not prevented, it always made an attempt to break the fish behind the anal fin, which is next the tail; and, as soon as one was taken away, it always dived in pursuit of more. It was equally dexterous at sea fishing, and took great numbers of young cod, and other fish, there. When tired, it would refuse to fish any longer, and was then rewarded with as much as it could devour. Having satisfied its appetite, it always coiled itself round, and fell asleep: in which state it was generally carried home." Professor Steller says that on killing and skinning a female otter, which he found at a place at which he had deprived her of her young eight days previously, he found her quite wasted away from grief at the loss of her progeny.

The Badger. There are several varieties of Badger, the Indian and the American being the most important, respectively of the eastern and western worlds. The common badger (Meles taxus), which is found in different parts of England, feeds upon roots, bulbs, fruits, and all kinds of vegetables, as well as small animals, snails and worms. He has also a great fancy for eggs. He lives in burrows, which 
form passages having a central chamber and various antichambers, which he makes in sandy and gravelly soil. $\mathrm{He}$ is nocturnal in his habits. "When pursued," says Mrs. Bowdich, " he constantly impedes the progress of his enemies by throwing the soil behind him, so as to fill up the passages, while he escapes to the surface." $\mathrm{He}$ is a formidable opponent to his enemies, as his skin is so tough and his bite so severe, and he displays much sagacity in avoiding traps and escaping confinement. Mr. St. John placed one in a paved court for security, but before the next morning he had displaced a stone and burrowed his way out under the wall. Captain Brown tells an affecting story of the feeling of a badger for its mate. "Two persons in France killed a badger and proceeded to drag it towards a neighbouring village. They had not proceeded far when they heard the cry of an animal in seeming distress, and stopped to listen, when another badger approached them slowly. They at first threw stones at it; notwithstanding which, it drew near, came up to the dead animal, began to lick it, and continued its mournful cry. The men, surprised at this, desisted from offering any further injury to it, and again drew the dead one along as before; when the living badger, determined not to quit its companion, lay down on it, taking it gently by one ear, and in that manner was drawn into the midst of the village; nor could dogs, boys, or men induce it to quit its situation: and to their shame be it said, they had the inhumanity to kill the poor animal, and afterwards to burn it, declaring it could be no other than a witch."

The Ratel The Ratel (Mellivora capensis) of South and and the East Africa and the Skunk of Canada belong skunk. to this family. The Ratel is a small animal standing from ten to twelve inches high, with a very tough skin, which is so loose that, to quote Sparrman, "If anybody catches hold of the Ratel by the hind part of his neck, he is able to turn round, as it were, in his, skin, and bite the 
arm of the person that seizes him." Dog-like in shape, the back and head are covered with a coat of lighter colour than that of the sides and under part of the body, giving it the appearance of a garment. The Ratel is the natural enemy of the Bees, his thick skin rendering him impervious to their attack, and he is said to show great sagacity in tracing their nests, watching at sundown, with his eyes shaded by his paws, the homeward flight of the honey makers and then following them to plunder and destroy. The Skunk is famous for its offensive smell, which according to Sir John Richardson is emitted by a deep yellow fluid which it discharges, and which is so strong that it retains its disgusting odour for many days. It is about eighteen inches in length, has short legs and a body that is broad and flat. It lives upon poultry and eggs, small quadrupeds, young birds, and wild fruits. Godman says: "Pedestrians, called by business or pleasure to ramble through the country during the morning or evening twilight, occasionally see a small and pretty animal a short distance before them in the path, scampering forward without appearing much alarmed, and advancing in a zigzag or somewhat serpentine direction. Experienced persons generally delay long enough to allow this unwelcome traveller to withdraw from the path; but it often happens that a view of the animal arouses the ardour of the observer, who, in his fondness for sport, thinks not of any result but that of securing a prize. It would be more prudent to rest content with pelting this quadruped from a safe distance, or to drive it away by shouting loudly; but almost all inexperienced persons, the first time such an opportunity occurs, rush forward with intent to run the animal down. This appears to be an easy task; in a few moments it is almost overtaken; a few more strides and the victim may be grasped by its long and waving tail--but the tail is now suddenly curled over the back, its pace is slackened, and in one instant the condition of things is entirely reversed;-the 
lately triumphant pursuer is eagerly flying from his intended prize, involved in an atmosphere of stench, gasping for breath, or blinded and smarting with pain, if his approach were sufficiently close to allow of his being struck in the eyes by the pestilent fluid of the Skunk."

Tho

Our next concern is with the family of the Raccoon and procyonidæ which includes several bear-like the Coati. animals, the Raccoon and the Coati being the best known. The raccoon belongs to North America, the coati to Central and Southern America. The raccoon is an expert swimmer, about the size of a fox, and of nocturnal habits. "His food," says the Rev. J. G. Wood, "is principally small animals and insects." Oysters are also a very favourite article of its diet. It bites off the hinge of the oyster, and scrapes out the animal with its paws. Like a squirrel, when eating a nut, the raccoon usually holds its food between its fore-paws pressed together and sits upon its hind quarters while it eats. It is said to be as destructive in a farm-yard as any fox, for it only devours the heads of the murdered fowl. When taken young it is easily tamed but very frequently becomes blind soon after its capture. The coati (Nasua nasica) is distinguished from the raccoon by a pointed nose. In size it resembles the cat, its tail being as long as its body. Like the cat it is a good climber, and preys upon birds. When domesticated, as it is in Paraguay, the coati is kept in tether, as its climbing habits render it dangerous to ornaments and furniture. The Kinkajou (Cercoleptes caudivolvulus) of Demerara belongs to this family. The Panda (ZElurus fulgens) constitutes another family. It is cat-like in the face, but otherwise resembles the bear. It lives in the dense forests which clothe the declivities of the Himalayas.

The Bear. After the lion and the tiger the bear is probably the most popular animal in legend and story. Dr. Gray divides the bears into three classes: the sea bear, 
the land bear, and the honey bear. The polar bear is the sea bear; the brown bear, the black bear, and the grizzly are land bears, and the Malayan bear is the honey bear. Mr. Wood says, "Bears and their allies are mostly heavy, and walk with the whole foot placed flat on the ground, unlike cats and dogs who walk with merely their paws or toes. They are omnivorous, that is, they can eat either animal or vegetable food, so that a leg of mutton, a pot of honey, a potatoe, or an apple are equally acceptable." The bears of Kamtchatka live principally on fish, which they are adepts in catching. The bear is found in the polar regions, in Siberia, the Caucasus, the Pyrenees, the Himalayas, in various parts of Western Asia, in Canada, and the United States.

The Polar The Polar Bear is eight or nine feet long, and Bear. a little more than four feet in height. He has a long nose, short ears, large legs, and a short tail. His body and neck are long, and he has five sharp claws on each foot. His colour is a yellowish white; his hair long and shaggy. He inhabits Greenland and Lapland, as far north as eighty degrees. He lives on fish and seals and the bodies of whales, which are thrown ashore or which he finds in the sea. Dr. R. Brown deprecates the stories of the polar bear's ferocity which he regards as greatly exaggerated, though he admits, that when enraged, or suffering from hunger, they are formidable foes. That they are wary animals the following story quoted from Captain Brown will show. "The captain of a Greenland whaler, being anxious to procure a bear without injuring the skin, made trial of a stratagem of laying the noose of a rope in the snow, and placing a piece of kreng within it. A bear, ranging the neighbouring ice, was soon enticed to the spot by the smell of burning meat. He perceived the bait, approached, and seized it in his mouth; but his foot, at the same time, by a jerk of the rope, being entangled in the noose, he pushed it off with his 

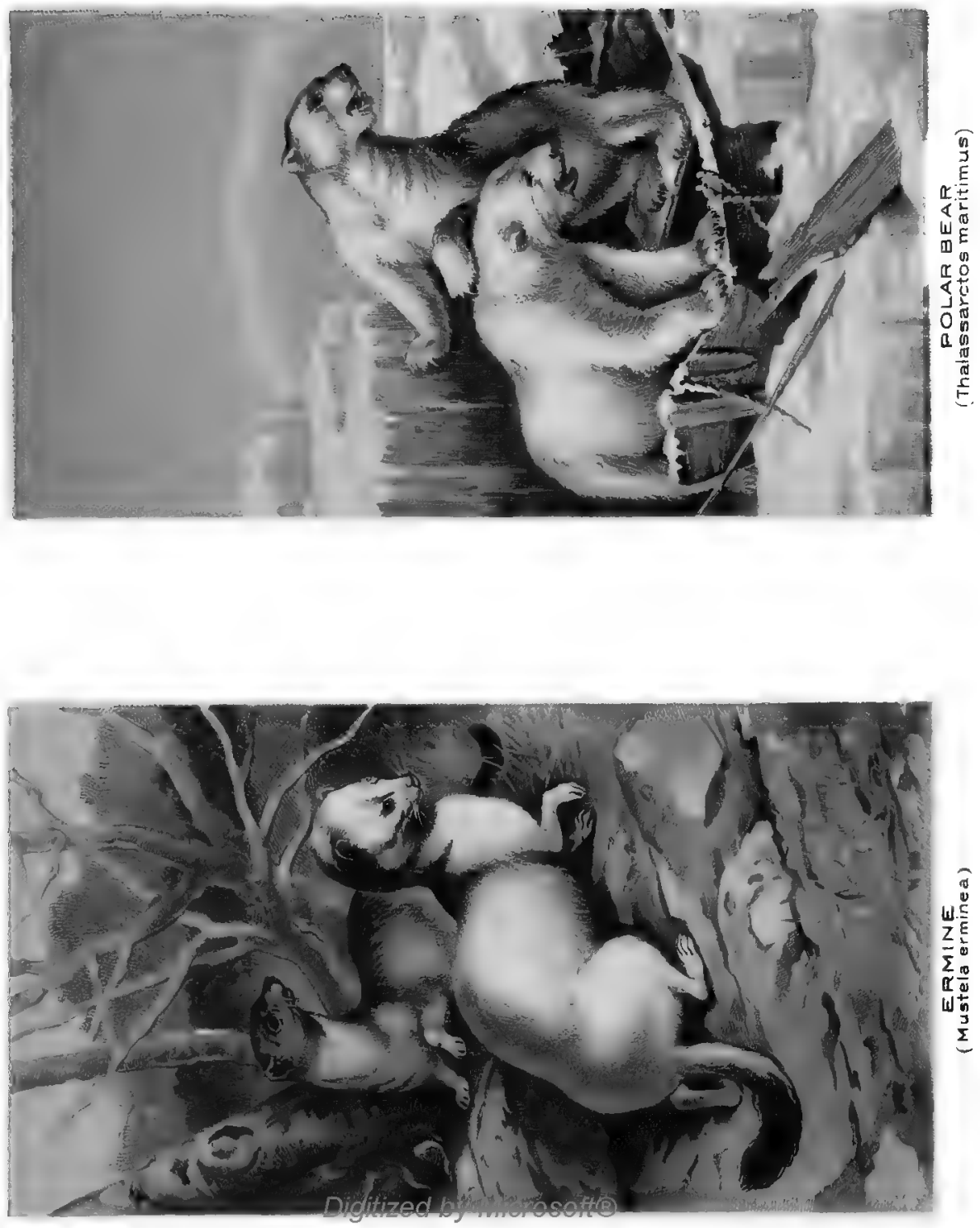
Digitized by Microsofte 
paw, and deliberately retired. After having eaten the piece he had carried away with him, he returned. The noose, with another piece of kreng, having been replaced, he pushed the rope aside, and again walked triumphantly off with the bait. A third time the noose was laid; but, excited to caution by the evident observations of the bear, the sailors buried the rope beneath the snow, and laid the bait in a deep hole dug in the centre. The animal once more approached, and the sailors were assured of their success. But Bruin, more sagacious than they expected, after snuffing about the place for a few moments, scraped the snow away with his paw, threw the rope aside, and again escaped unhurt with his prize."

The polar bear displays a great love for its young and many pathetic stories are told of its rage and grief at the loss of them. The following is from Captain Brown's "Anecdotes of Animals." "A Greenland bear, with two cubs under her protection, was pursued across a field of ice by a party of armed sailors. At first, she seemed to urge the young ones to increase their speed, by running before them, turning round, and manifesting, by a peculiar action and voice, her anxiety for their progress; but, finding her pursuers gaining upon them, she carried, or pushed, or pitched them alternately forward, until she effected their escape. In throwing them before her, the little creatures are said to have placed themselves across her path to receive the impulse, and, when projected some yards in advance, they ran'onwards, until she overtook them, when they alternately adjusted themselves for another throw."

The Black The Black Bear (Ursus Americanus) is about Bear. four and a half feet long and three feet high. $\mathrm{He}$ has long feet terminating in five claws each. His body is short with longish legs, and he has a large head, with small eyes, and a sharp nose. He has long, soft and woolly hair. His food is chiefly fruit, such as acorns, chestnuts, grapes, 
and corn; but when hungry he will feed on flesh, and attack other animals with courage and fierceness. He climbs trees, and uses his paws like hands. In winter he retires to his den, which is usually a hollow in some decayed tree, where he hybernates until spring. Though of a wild disposition, he can be tamed, and taught various tricks, in which he displays a good deal of sagacity and docility. The following story is quoted by Captain Brown from Captains Lewis' and Clarke's travels to the source of the Missouri, as a striking instance of the astonishing physical powers of the bear. "One evening, the men in the hindmost of the canoes, discovered a large bear lying in the open grounds, about three hundred paces from the river. Six of them, all good hunters, set out to attack him; and, concealing themselves by a small eminence, came unperceived within forty paces of him. Four of them now fired, and each lodged a ball in his body, two of them directly through the lungs. The enraged animal sprang up, and ran open-mouthed at them. As he came near, the two hunters who had reserved their fire, gave him two wounds, one of which, breaking his shoulder, retarded his motion for a moment; but, before they could reload, he was so near, that they were obliged to run to the river, and, when they reached it, he had almost overtaken them. Two jumped into the canoe; the other four separated, and, concealing themselves in the willows, fired as fast as each could load. They struck him several times, which only exasperated him; and he at last pursued two of them so closely, that they leaped down a perpendicular bank of twenty feet into the river. The bear sprang after them, and was within a few feet of the hindmost, when one of the hunters from the shore shot him in the head, and killed him. They dragged him to the banks of the river, and found that eight balls had passed through his body."

Of his docility Mrs. Bowdich gives the following amusing, if, at the time, alarming illustration. "A young English officer, 
who was stationed at a lone fortress in Canada, amused himself by taming a bear of this species. He taught him to fetch and carry, to follow him like a dog, and to wait patiently at meal times for his share. The bear accompanied him when he returned to England, and became a great avourite with the passengers and the ship's company. Bruin, however, especially attached himself to a little girl about four years old, the daughter of one of the ladies on board, who romped with him as she would with a dog. In one of these games of piay, he seized her with one fore-paw, and with the other clambered and clung to the rigging, till he lodged her and himself in the main-top, where, regardless of her cries and the agony of her mother, he tried to continue his romp. It would not do to pursue the pair, for fear the bear should drop the child; and his master, knowing how fond he was of sugar, had some mattresses placed round the mast in case the child should fall, and then strewed a quantity of sugar on the deck; he called Bruin, and pointed to it, who, after a moment's hesitation, came down as he went up, bringing the child in safety. He was, of course, deprived of his liberty during the rest of his voyage." The black bear is hunted for the sake of his skin, many thousands of skins being sent to Europe every year.

The Grizzly The Grizzly Bear is an enormous animal, accord-

Bear. ing to the measurement of Captains Lewis and Clarke of one they killed, nine feet from nose to tail, though they claim to have seen one of even larger size. It is said to attain to a weight of 800 pounds. The fore-foot of the animal already referred to exceeded nine inches in length, the hind foot being eleven inches and three quarters, exclusive of the talons, the breadth of the hind foot being seven inches. The Grizzly does not climb trees, like the brown and the black bear. $\mathrm{He}$ is ferocious when hungry, and when attacked, and the female will die hard in the defence of her young. Such is his strength that he can 
master a bison, and drag him to his retreat. He is by far the most dangerous brute of North America. He unhesitatingly pursues both men and animals; but, though he feeds on flesh, he is capable of subsisting upon roots and fruits. $\mathrm{He}$ is very tenacious of life, and will pursue his enemy after having received repeated mortal wounds. $\mathrm{He}$ is found in the eastern vicinity of the Rocky Mountains. Though the Grizzly will sometimes move off on the approach of the traveller, without showing fight, he will at other times attack him with great ferocity. A man named Nathan Rogers who lived on a ranch in the mountains about a mile above West Point, near the North Fork of the Mokelumne, once had a terrific encounter with a grizzly bear. He was out shooting small game when he was suddenly confronted by an enormous animal. He fired his only shot into the breast of the bear and then awaited his attack. The fight was fast and furious, and though in the end the grizzly was killed, the man only survived in a terrible condition. Conscious that he must soon have help or perish, he summoned all his resolution and staggered along, and managed to reach a spring in sight of a house, when his endurance gave way, and he fell in a dead faint by the water's edge. Fortunately he was soon discovered by his son, a lad of some twelve years, who immediately gave the alarm. In addition to his horrible wounds, the shock to his system was a terrible one. His left arm, literally mangled and torn to shreds, had to be amputated at the shoulder. His left clavicle and scapula were fractured, and the three lower ribs on the right side broken. The flesh and muscles on his back were so broken and abraded that the vertebræ were actually visible in places; while, his lower limbs were literally seamed and furrowed by the crooked claws of the bear's hind feet. The left side of the bear was literally torn to pieces, there being no less than twenty-two knife-wounds, nearly every one of which reached to a vital point. Some idea of his size 
can be obtained when we state that one of his fore-paws just covered an ordinary dinner plate.

The The Brown Bear (Ursus arctos) was the bear Brown Bear. of the British Isles, so long as the British Isles boasted of a bear. This was the baited bear of the Royal sports, and of the common Bear garden. His last appearance in Great-Britain in a wild state, however, dates back more than 800 years. In size, shape, and habits he much resembles the black bear of America. Like the Malayan bear he is very fond of honey as the following amusing story as told by Mrs Bowdich will show:

"A countryman in Russia, when seeking honey, climbed a very high tree, the trunk of which was hollow; and finding there was a large quantity of comb in it, he descended, and stuck fast in the tenacious substance there deposited. $\mathrm{He}$ was so far distant from home, that his voice could not be heard, and he remained two days in this situation, relieving his hunger with the honey. He began to despair of ever being extricated, when a bear, who, like himself, came for the sake of the honey, slid down the hollow, hind-part foremost. The man, in spite of his alarm, seized hold of him; and the bear, also in a great fright, clambered out as fast as he could, dragging the man up with him, and when clear of his tail-bearer, made off as fast as possible."

The

The Malayan Bear is about four feet long and Malayan Bear. two feet high. It has a long tongue which serves it well in extracting honey from the honey combs in the hollow trunks of trees. Other bears are the Syrian Bear of Western Asia, the Spectacled Bear of South America and Peru and the Sloth Bear of India and the Mahratta country. SUB-ORDER II. We come now to the second sub-order of the

The Carnivora or flesh-eating animals, the sub-order

Pinnipedia. which includes the Seal and the Walrus. These in the form of their skulls and in other ways show evident relationship to the bear, and so appropriately follow him in classifica- 
tior. The family of the Otaridæ, includes the Eared Seals, the Northern Sea Lion and the Northern Sea Bear. The Eared Seal is distinguished from the true seal, as his name implies by the possession of external ears.

Sea Lions. Mr. Theodore Lyman, who had excellent opportunities of observing the habits of the Sea Lions on the Seal Rocks of San Francisco, furnished Mr. Allen with a graphic account of their movements, from which we quote the following: "As they approach to effect a landing, the head only appears decidedly above water. This is their familiar element and they swim with great speed and ease, quite unmindful of the heavy surf, and of the breakers on the ledges. In landing they are apt to take advantage of a heavy wave which helps them to get the forward flippers on terra firma. As the wave retreats they begin to struggle up the steep rocks, twisting the body from side to side, with a clumsy worm-like motion, and thus alternately work their flippers into positions, where they may force the body a little onward. At such times they have a general appearance of sprawling over the ground. It is quite astonishing to see how they will go up surfaces having even a greater inclination than $45^{\circ}$ and where a man would have to creep with much exertion. In their onward path they are accompanied by the loud barking of all the seals they pass; and these cries may be heard a great distance. They play among themselves continually by rolling on each other and feigning to bite; often too, they will amuse themselves by pushing off those that are trying to land. All this is done in a very cumbrous manner, and is accompanied by incessant barking. As they issue from the water their fur is dark and shining; but as it dries, it becomes of a yellowish brown. Then they appear to feel either too dry or too hot, for they move to the nearest point from which they may tumble into the sea. I saw many roll off a ledge at least twenty feet high, and fall like so many huge brown sacks into the water, dashing up showers of spray." 
Sea Bears. The Northern Sea Bear is otherwise known as the Northern Fur Seal. Captain Charles Bryant gives a very interesting account of these singular animals, in which he describes them as approaching and taking possession of the shores of St. Paul's Island near the coast of Alaska, about the middle, or towards the end of April, when the snow has melted and the drift ice from the north has all passed. A few old male seals first make their appearance and reconnoitre for two or three days, afterwards climbing the slopes and taking possession of the rookeries, each male reserving about a square rod for himself and his wives. The scouts then return and younger male seals soon begin to arrive in small detachments, but are prevented from landing by their elders and are so forced to remain in the water or go to the upland above. By the middle of June all the males have arrived, and having adjusted their differences and divided the rookeries between them, await the arrival of the females. "These appear in small numbers at first but increase as the season advances, till the middle of July; when the rookeries are all full, the females often overlapping each other. The bachelor seals swim all day along the shore, escorting and driving the females on to the rocks as fast as they arrive. As soon as a female reaches the shore, the nearest male goes down to meet her, making meanwhile a noise like the clucking of a hen to her chickens. He bows to her, and coaxes her until he gets between her and the water so that she cannot escape him. Then his manner changes, and with a harsh growl he drives her to a place in his harem. This continues until the lower row of harems is nearly full. Then the males higher up select the time when their more fortunate neighbours are off their guard to steal their wives. This they do by taking them in their mouths and lifting them over the heads of the other females, and carefully placing them in their own harem carrying them as carefully as cats do their kittens. Those still higher up pursue the same method until 
the whole space is occupied. Frequently a struggle ensues between two males for the possession of the same female, and both seizing her at once, pull her in two, or terribly lacerate her with their teeth. When the space is all filled, the old male walks around complacently reviewing his family, scolding those who crowd or disturb the others, and fiercely driving off all intruders. This surveillance always keeps him actively occupied." After the birth of their young which takes place towards the end of July, the old males who have been four months without food, go to some distance from the shore to feed, teaching the young to swim on their return. "By the last of October the seals begin to leave the islands in small companies. The males going last and by themselves."

The Walrus. The Walrus (Trichechus rosmarus) is a large and unwieldy creature. It bears a stronger resemblance to the seal than to any other quadruped, but it is distinguished by the proportions of its body and its elephant-like tusks. Vast herds formerly frequented the shores of the islands scattered between America and Asia, the coasts of Davis's Straits and those of Hudson's Bay. They have been found as far south as the Magdalen Islands in the Gulf of St. Lawrence. Now they are not met with in great numbers, except on the shores of Spitzbergen and the remotest northern borders of America. They attain to a very large size. The head is oval, short, small, and flat in front, having the eyes set in deep sockets so as to be moved forwards, or retracted at pleasure. On land the Walrus is a slow' and clumsy animal, but in the water its motions are sufficiently quick and easy. When attacked, the Walrus is both fierce and formidable, and if in company with its young, becomes very furious, attempting to destroy its enemies by rising and hooking its tusks over the sides of the boat, in order to sink it.

Captain Cook thus describes a herd of walruses he met with off the north coast of America. He says: "They lie 
in herds of many hundreds upon the ice, huddling over one another, like swine; and roar or bray so very loud, that in the night, or in foggy weather, they gave us notice of the ice, before we could see it. We never found the whole herd asleep, some being always upon the watch. These, on the approach of the boat, would awake those next to them; and the alarm being thus gradually communicated, the whole herd would be awake presently. But they were seldom in a hurry to get away, till after they had been once fired at. They then would tumble over one another into the sea, in the utmost confusion; and, if we did not, at the first discharge, kill those we fired at, we generally lost them, though mortally wounded. They did not appear to us to be that dangerous animal which some authors have described, not even when attacked. They are more so in appearance than reality. Vast numbers of them would follow, and come close up to the oars; but the flash of the musket in the pan, or even the bare pointing of one at them, would send them down in an instant. The female will defend her young to the very last, at the expense of her own life, whether in the water or upon the ice. Nor will the young one quit the dam, though she be dead; so that, if one is killed, the other is certain prey. The dam, when in the water, holds the young one between her fore arms."

The Common The True Seals are divided by Dr. Gray into Seal. thirteen genera with eighteen species, of which the Common Seal, the Ringed Seal; the Harp Seal, the Grey Seal, the Sea Leopard, the Sea Elephant, and the Bladdernose Hooded Seal are the best known. The common seal has a round head which in front bears some resemblance to that of the otter. Its average length is about five feet and its general colour of a yellowish gray, varied or spotted with brown or blackish in different degrees, according to the age of the animal. The Common Seal frequents the sea-coasts perhaps throughout the world, but is most numerous in high 
northern latitudes, and furnishes the inhabitants of those frigid regions with nearly all their necessaries and luxuries. Enormous numbers are caught annually for the sake of their skins and oil. The Harp Seal frequents the coast of Newfoundland and is so named from the harp-shaped band which marks the backs of the males. The Sea Elephant is the largest of the seals. It is said to attain to the length of twenty-five to thirty feet, and a circumference of fifteen to eighteen feet. It belongs to the Antarctic sea.

"Seals when taken young," says Captain Brown, "are capable of being completely domesticated, will answer to their name, and follow their master from place to place. In January, I8I9, a gentleman, in the neighbourhood of Burntisland, county of Fife, in Scotland, completely succeeded in taming a seal. Its singularities attracted the curiosity of strangers daily. It appeared to possess all the sagacity of a dog, lived in its master's house, and ate from his hand. In his fishing excursions, this gentleman generally took it with him, when it afforded no small entertainment. If thrown into the water, it would follow for miles the track of the boat; and although thrust back by the oars, it never relinquished its purpose. Indeed, it struggled so hard to regain its seat, that one would imagine its fondness for its master had entirely overcome the natural predilection for its native element."

The Seal's Notwithstanding the absence of external ears

Docility. the common seal has a remarkable sense of hearing and a keen taste for sweet sounds. Seals have been known to follow a vessel, for miles, upon the deck of which a violin or a flute has been played. To quote Sir Walter Scott:

$$
\begin{aligned}
& \text { "Rude Heiskar's seals, through surges dark, } \\
& \text { Will long pursue the minstrel's bark." }
\end{aligned}
$$

They are also easily tamed, when they are found to be exceedingly affectionate to those who treat them kindly. Some years ago a farmer, residing on the east coast of Scotland, 
close to the sea-shore, obtained a young seal for the amusement of his children, who soon became exceedingly fond of it. Some time after, the farmer, having had a bad year for his crops, was told by an old woman in the village that he would never prosper as long as he kept that seal on his ground. The foolish man giving heed to the superstition sent away the seal in a boat some distance from land. Towards evening, as the children were sitting on the sea-shore, what was their joy on beholding their seal rising out of the water, and making its way straight back to them again. For some months they were allowed to retain their pet; but as the farmer's prospects did not brighten, he again determined to get rid of it, and for that purpose, hearing of a ship that was soon to sail for the Baltic, took the little seal, and gave it in charge to some sailors, begging them to keep it in the hold of the ship till they arrived at their destination, and then to throw it into the sea. This was accordingly done, but the faithful seal was not to be daunted; ere long, it reappeared, to the great delight of the children, who begged their father never to send it away again. The farmer gave a doubtful assent, for a suspicion still lurked in his mind, owing to the superstitious words of the old woman, that the presence of the seal had an evil effect upon his crops; and with these ideas preying upon his mind, the farmer conceived the cruel thought of putting out the seal's eyes with a view of preventing it from finding its way back, and again sending it away to sea. Unknown to his children, he carried this barbarous plan into execution; and they only discovered the loss of their favourite too late to aid in its recall, as the ship in which it had been placed had already sailed for Norway. Some days after the departure of the vessel, a fearful storm arose. The farmer and his family were glad enough to close up their shutters, and shut out as much as possible the wailings of the wind, as it swept in furious gusts round the house. They had scarcely retired to rest, when a faint and 
plaintive sry struck upon their ears-and repeated again it seemed to be-during the momentary lulls of the storm. The farmer continued to listen, but hearing nothing more, he descended to the front door and opened it; a dark object lay before him, on the very threshold, and stooping down to touch it, what was his astonishment to behold the poor blind, devoted little seal, apparently dead. The farmer was greatly touched; he took up the little body gently and carried it into the kitchen, and used every effort to restore it to life but in vain.

ORDER V. This order is divided into two sub-orders, the Whales and one characterised by the possession of teeth, and Dolphins. the other being toothless.

The Right The Right Whale when fully grown, attains to Whale. from fifty to sixty-five feet in length, and to from thirty to forty feet in circumference. It is thickest behind the fins. When the mouth is open, it presents a cavity as large as a room, and capable of containing a boat full of men. Its tongue is said to be as large as a stout feather-bed. The tail is a powerful instrument of motion and defence: it is only five or six feet long, but its motions are rapid, and its strength immense. The eyes are situated in the sides of the head; they are very small, being little larger than those of an ox. The whale has no external ear, but there is a small orifice under the skin for the admission of sound. On the most elevated part of the head are two blow holes six or eight inches in length. The mouth, instead of teeth, has two rows of whalebone, each of which contains more than three hundred laminæ, the longest of which are about ten or eleven feet. A large whale sometimes contains a ton and a half of whalebone. The colour of the old whale is gray and white, that of the young ones a sort of bluish black. Immediately beneath the skin lies the blubber, or fat; its thickness round the body is eight or ten or twenty inches, varying in different parts: the lips are composed almost 
entirely of blubber. A large whale yields about twenty tons of oil, which is expressed from the blubber. It is for this and the whalebone that this animal is deemed so valuable, and for which it is so much sought by whalefishers. The sense of seeing in the whale is very acute. Under the surface of the water they discover one another at an amazing distance. They have no voice, but in breathing or blowing they make a loud noise.

The usual rate at which whales swim seldom exceeds four miles an hour, but for a few minutes at a time they are capable of darting through the water with amazing velocity, and of ascending with such rapidity as to leap above the surface. This feat they perform as an amusement, apparently to the high admiration of distant spectators. Sometimes they throw themselves in a perpendicular posture, with the head downwards, and rearing their tails on high, beat the water with awful violence. Sometimes they shake their tails in the air, which, cracking like a whip, resound to the distance of two or three miles. The flesh of the whale, though it would be rejected by the dainty palates of refined nations, is eaten with much relish by the Eskimo, and the inhabitants along the coasts of Hudson's Bay and Davis's Straits, who esteem it a staple article of subsistence.

Other whales of this sub-order are the common Fin Whale, which is said to reach eighty feet in length, the lesser Fin Whale and the Humpback Whale. In these, the yield of whalebone and oil is so small that they are not thought worth the trouble of catching.

The sperm The Sperm Whale rarely exceeds sixty feet in

whale. length and lives in warm regions, such as the Indian Ocean; rarely, if ever, visiting Arctic or European seas. Its yield of oil is said to be less than that of the Greenland whale but it is of a finer quality. Ambergris is also produced from the body of the sperm whale.

The Dolphin. This is a large creature, so like the porpoise 
that he has been often confounded with it. He is, however, much larger, sometimes measuring from twenty to twenty-five feet in length. The body is roundish, growing gradually less towards the tail; the nose is long and pointed, the skin smooth, the back black or dusky blue, becoming white towards the belly. He is entirely destitute of gills, or any similar aperture, but respires and also spouts water through a pipe of semi-circular form placed on the upper part of the head. There are several varieties of dolphins, including the Longnosed Dolphins of the rivers of Asia and South America and the Classical Dolphin of the Mediterranean (Delphinus delphis) The former are separately classified, and the family of the latter includes the White Whale, the Narwhal, the Common Porpoise and the Grampus. The dolphin is gregarious in its habits, herding and travelling in large shoals. It may sometimes be seen sporting in the bays and rivers of New York and is always a pretty sight.

The White The White Whale (Beluga catodon) is the whale

Whale which Dr. R. Brown calls the whale of Greenland. It is the whale which the Greenlander and the Eskimo find so valuable for its oil and flesh, the latter of which they dry for winter use. They are sometimes called sea pigs, from a fancied resemblance they bear to the pig when floundering in the sea, and sometimes sea canaries, on account of their peculiar whistle, which resembles that of a bird.

The Narwhal The narwhal (Monodon monoceros) is found frequently in company with the white whale, and inhabits much the same geographical area. It is distinguished by the possession of a tusk, the aim and purpose of which has been much debated. "It has been supposed to use it," says Dr. Brown, "to stir up its food from the bottom, but in such a case the female would be sadly at a loss. Fabricius thought that it was to keep the holes open in the ice during the winter; and the following occurrence seems to support this view. In April, I860, a Greenlander was travelling along the 
ice in the vicinity of Christianshaab, and discovered one of those open spaces in the ice, which, even in the most severe winters, remain open. In this hole hundreds of narwhals and white whales were protruding their heads to breathe, no other place presenting itself for miles around. It was described to me as an Arctic 'Black Hole of Calcutta' in the eagerness of the animals to keep at the place." "Neither the narwhal nor the white whale," he continues, are timid animals, but will approach close to, and gambol for hours in the immediate vicinity of the ship." The oil is highly esteemed, and the flesh is very palatable. The skin of the narwhal boiled to a jelly is looked upon, and justly so, as one of the prime dainties of a Greenlander.

The Common The Porpoise resembles the dolphin in general

Porpoise. appearance. Its length, from the tip of the snout to the end of the tail, is from five to eight feet; and the width about two feet and a half. The figure of the whole body is conical; the colour of the back is deep blue, inclining to shining black; the sides are gray, and the belly white. When the flesh is cut up, it looks very much like pork; but, although it was once considered a sumptuous article of food, and is said to have been occasionally introduced at the tables of the old English nobility, it certainly has a disagreeable flavour. Their motion in the water is a kind of circular leap; they dive deep, but soon again rise up in order to breathe. They are seen in nearly all seas, where they sport with great activity, chiefly on the approach of a squall.

The The Grampus (Orca Gladiator) is the natural Grampus. enemy of the whale and the seal, who hold him in mortal terror. His swallow is so great that he can take a porpoise or a seal whole, and has been known to swallow several in succession. The whale escapes him by getting among the ice, whither it is said the grampus will not follow him. 
ORDER VI. The Sea Cow is an aquatic vegetarian who The Sea lives on the coast. Of the three genera which Cow. constitute the family Manatide one is now said to be extinct. The genus Manatus contains two species, one belonging to South America and the other to the West Coast of Africa. The Dugong (Halicore Dugong) which attains to a length of nine or ten feet at maturity produces oil having similar medicinal properties to that obtained from the Cod's liver. It inhabits the Indian Ocean, the Red Sea, the neighbourhood of the Malay Islands and the North and East coasts of Australia.

ORDER VII. The order of hoofed animals includes a Hoofed number of well known species, of which the Animals. Horse, the Ass, the $\mathrm{Ox}$ and the Sheep among the tame, and the Rhinoceros, the Hippopotamus, the Boar and the Bison among the wild are familiar examples. The order is divided into two sub-orders and these into numerous families. The sub-orders are, I, The Perissodactyla, which includes three families of animals characterised by an odd number of toes in their hind feet, the horse having one, and the Rhinoceros three. II, The Artiodactyla which includes seven families of animals all having an even number of toes.

The Borse. The horse stands first among the hoofed animals, as the friend and servant of man. He has a history which is full of interest but which it is quite impossible to give within the limits of our present opportunity. He is mentioned in both classical and Biblical history at an early period, but there is reason to believe that he flourished in prehistoric times. He was used by the Greeks in their public games, the chariot race being one of their most popular forms of entertainment; he was also employed by them for the purposes of war, of which the writings of Homer and other classical authors give abundant proof. First used apparently to draw the chariot only, the adaptation of the means to the 
end soon suggested to man the propriety of mounting his back, and from the throne he thus acquired man has since conquered the whole world. Man's first appearance on horseback doubtless suggested the fable of the Centaur; those unaccustomed to the sight imagining that they beheld a monster, half man and half horse, as it is said the aborigines of America did when they first saw Spanish equestrians. The Egyptians are said to have been the first to cultivate the horse, and the Persians the first to use him in battle.

Arabian The beauty, strength and speed of the Arabian

Horses. horse are well known, and the affection which subsists between him and his master is the basis of many a pathetic story. These horses are generally of a brown colour; the mane and tail being short, and the hair black and tufted. The Arabs for the most part use the mares in their ordinary excursions, as they are less vicious than the males, and are more capable of sustaining abstinence and fatigue.

The Arab often shares his tent with his mare, the husband, the wife, the child, the mare, and the foal, lying together indiscriminately; and the youngest branches of the family embracing the neck, or reposing on the body, of the mare, without any idea of fear or danger.

St. Pierre in his "Studies of Nature" tells a pretty story of the Arab's affection for his horse: "The whole stock of a poor Arabian of the desert consisted of a beautiful mare; this the French consul at Said offered to purchase, with an intention to send her to Louis XIV. The Arab, pressed by want, hesitated a long time, but at length consented, on condition of receiving a very considerable sum of money, which he named. The consul wrote to France for permission to close the bargain; and, having obtained it, sent the information to the Arab. The man, so indigent as to possess only a miserable covering for his body, arrived with his magnificent courser; he dismounted, and first looking at the gold, then steadfastly at his mare, heaved a sigh. 'To 
whom is it,' exclaimed he, 'that I am going to yield thee up? To Europeans! who will tie thee close, who will beat thee, who will render thee miserable! Return with me, my beauty, my jewel! and rejoice the hearts of my children.' As he pronounced the last words, he sprang upon her back, and was out of sight almost in a moment." This story forms the subject of the well known ballad by the Hon. Mrs. Norton, entitled "The Arab's farewell to his steed."

Clarke thus describes the way in which the Arab will address a horse:- "Ibrahim went frequently to Rama to inquire news of the mare whom he dearly loved; he would embrace her, wipe her eyes with his handkerchief, would rub her with his shirt sleeves, would give her a thousand benedictions during whole hours that he would remain talking to her. 'My eyes! my soul! my heart!' he would say, 'must I be so unfortunate as to have thee sold to so many masters, and not keep thee myself? I am poor, my antelope! I brought thee up in my dwelling as a child; I did never beat nor chide thee__ " Arabs have been known to refuse enormous sums for horses, though actually themselves in a condition of extreme want. That the horse can reciprocate the kindness shown to him is proved by many a story of his fidelity. Chateaubriand says, "When I was at Jerusalem the feats of one of these steeds made a great noise. The Bedouin to whom the animal, a mare, belonged, being pursued by the governor's guards, rushed with her from the top of the hills that overlooked Jericho. The mare scoured at full gallop down an almost perpendicular declivity without stumbling, and left the soldiers lost in admiration and astonishment. The poor creature, however, dropped down dead on entering Jericho, and the Bedouin, who would not quit her, was taken, weeping over the body of his faithful companion."

More romantic is the story told by M. de Lamartine, thus quoted by Mrs. Bowdich. "An Arab chief and the tribe to which he belonged attacked a caravan in the night, and were 
returning with their plunder, when some horsemen belonging to the Pasha of Acre surrounded them, killed several, and bound the rest with cords. Among the latter was the chief Abou el Marek, who was carried to Acre, and, bound hand and foot, laid at the entrance of their tent during the night. Kept awake by the pain of his wounds he heard his horse, who was picketed at a distance from him, neigh. Wishing to caress him, perhaps for the last time, he dragged himself up to him, and said, 'Poor friend! what will you do among the Turks? You will be shut up under the roof of a khan, with the horses of a Pasha or an Aga. No longer will the women and children of the tent bring you barley, camel's milk, or dhourra, in the hollow of their hands; no longer will you gallop free as the wind in the desert; no longer will you cleave the waters with your breast, and lave your sides, as pure as the foam from your lips. If I am to be a slave, at least you may go free. Return to our tent, tell my wife that Abot el Marek will return no more; but put your head still into the folds of the tent, and lick the hands of my beloved children.' With these words, as his hands were tied, the chief with his teeth undid the fetters which held the courser bound, and set him at liberty; but the noble animal, on recovering his freedom, instead of galloping away to the desert, bent his head over his master, and seeing him in fetters and on the ground, took his clothes gently between his teeth, lifted him up, and set off at full speed towards home. Without resting he made straight for the distant but well-known tent in the mountains of Arabia. He arrived there in safety, laid his master down at the feet of his wife and children, and immediately dropped down dead with fatigue. The whole tribe mourned him, the poets celebrated his fidelity, and his name is still constantly in the mouths of the Arabs of Jericho."

For the sake of the beautiful moral it contains the following story is well worth adding. In the tribe of Negde there 
was a mare of great reputation for beauty and swiftness, which a member of another tribe named Daber desired to possess. Having failed to obtain her by offering all he was worth, he sought to effect his object by stratagem. Disguised as a lame beggar he waited by a roadside, knowing that Nabee, the owner of the horse, would shortly pass that way. As soon as Nabee appeared, Daber cried out to him, begging assistance and pretending to be too weak to rise. Nabee thereupon dismounted from the mare, and helped the beggar to mount her. The moment he was mounted Daber declared himself and made off. Nabee called to him to stop, and on his turning round said to him, "Thou hast my mare, since it pleased God I wish you success but I conjure thee tell no one how thou hast come by her." "Why not?" said Daber. "Lest others should refrain from charity because I have been duped," said Nabee, whereupon Daber dismounted and returned the mare.

The Domestic The Horse has only to be known to be loved,

Horse. and has only to be loved to become the most tractable, patient, and useful of animals. "In the domestic horse," says Colonel Smith, "we behold an animal equally strong and beautiful, endowed with great docility and no less fire; with size and endurance joined to sobriety, speed, and patience; clean, companionable, emulous, even generous; forbearing, yet impetuous; with faculties susceptible of very considerable education, and perceptions which catch the spirit of man's intentions, lending his powers with the utmost readiness, and restraining them with as ready a compliance: saddled or in harness, labouring willingly, enjoying the sports of the field and exulting in the tumult of the battle; used by mankind in the most laudable and necessary operations, and often the unconscious instrument of the most sanguinary passions; applauded, cherished, then neglected, and ultimately abandoned to the authority of bipeds who often show little superiority of reason and much less of temper." "One who, 
like ourselves," continues Colonel Smith, "has repeatedly owed life to the exertions of his horse, in meeting a hostile shock, in swimming across streams, and in passing on the edge of elevated precipices, will feel with us, when contemplating the qualities of this most valuable animal, emotions of gratitude and affection which others may not so readily appreciate."

The struc-

"The beauty of the form of the horse has often ture of a been commented upon, his structure is thus admir-

Horse. ably described by a writer in "Cassell's Magazine of Art": "His nature is eminently courageous, without ferocity, generous, docile, intelligent, and, if allowed to be so, almost as affectionate as the dog. In his structure, the ruling characteristic may be said in one word to consist in obliquity-all the leading bones in his frame are set obliquely, or nearly so, and not at right angles. His head is set on with a subtle curve of the last few vertebræ of the neck, which at the shoulders, take another subtle curve before they become the dorsal vertebræ, or backbone; which end, in their turn, with another curve, forming the tail. His shoulders slope back more than those of other quadrupeds, the scapula, or shoulder-blade, being oblique to the humerus, which, in its turn, is oblique to the radius, or upper part of the fore-leg. So, again, in the hind-quarters, the haunch is set obliquely to the true thigh, the thigh, at the stifle joint, to the upper bone of the hind-leg, which at the hock makes another angle. The fore and hind quarters form so large a portion of the entire length that a horse, though a lengthy animal from the front of the chest to the back of the haunch, is, comparatively, very short in the actual back or 'saddle-place.' Then his hocks are much bent, and his pastern joints are rather long, and again are set at an angle, succeeded by a slightly different angle in the firm but expanding hoof, thus completing the beautiful mechanism, which preserves the limbs from jar, and ensures elasticity in every part of an animal 
destined to carry weight and to undergo rapid and continued cxertion-a combination not existing in any other quadruped to anything like the same degree, and fitting him precisely for the purposes for which he was given to man. At present we have said nothing about his head, every part of which is equally characteristic. His well-shaped, delicate ears are capable of being moved separately in every direction, and every movement is full of meaning and in sympathy with the eye. The eye is prominent, full, and large, and placed laterally, so that he can see behind him without turning his head, his heels being his principal weapon of defence; his nostrils are large, open and flexible, and his lips fleshy, though thin, and exquisitely mobile and sensitive. The large, open nostril is essential to him, as a horse breathes solely and entirely through it, being physically incapable of breathing through his mouth, as a valve in the throat actually precludes him from so doing; hence the mouth of a horse, without a bridle in it, is opened only for purposes of eating or biting, but never from excitement or from exhaustion, like that of most other quadrupeds, except the deer species. The lips are, perhaps, even more characteristic; they are his hands as well as part of his mouth, and the horse and others of his family alone use them in this way. The ox, the sheep, the goat, the deer, the giraffe above all, and, in fact, we believe all graminivorous animals except the horse, either bite their food directly with the teeth, or grasp and gather it with the tongue, which is prehensile, and gifted with more or less power of prolongation; but the horse's tongue has no such function, and, therefore, no such powers, as these services are all performed in his case by the lips: and no horseman, who has let a favourite horse pick up small articles of food from the palm of his hand, can have failed to be struck with the extreme mobility, and also the sensibility and delicacy of touch, with which the lips are endowed." 
The Horse' The quality of speed for which the horse is speed. so justly esteemed has been the subject of extensive culture in which the Arabian horse has contributed no mean share. "Some of the horses first brought from Arabia having been by no means celebrated," says Captain Brown, "the breed had fallen into disrepute, till the descendants of one procured by Mr. Darley from the deserts, and on that account called the Darley Arabian, having borne away the palm for fleetness from all others, turned the tide of fashion in favour of that breed. Yet it is only the progeny of the Arabian horses that excels. The English race-horses are equal, if not superior, to all other coursers. As the extraordinary swiftness of the horse has been most signally displayed in the English race-course, and can also be there most precisely measured, we cannot omit the notice of some of the most remarkable of our racers. The most celebrated of these-and indeed the fleetest horse that ever was bred in the world-was Flying Childers, got by the Darley Arabian. What Achilles was among warriors, and Cæsar among conquerors, such was Childers among horses, without an equal and without a rival. He ran against the most famous horses of his age, and was always victorious. He has been known to move at the rate of nearly a mile in the minute. Next to Childers, in fame and fleetness, is Eclipse, so called from having been foaled during the great eclipse of 1764 . This horse likewise was never beaten: one contemporary rival alone was supposed to exist, Mr. Shaftoe's horse Goldfinder, but Goldfinder broke down the October before the proposed competition. Eclipse's rate of going was 47 feet in the second. Childers had a rate of 49 . One hundred to one were offered on Eclipse against the most famous racers of his day. Mr. O'Kelly purchased him for sixteen hundred and fifty guineas, and cleared by him twenty-five thousand pounds. He had a vast stride,-never horse threw his haunches below him with more vigour or effect; and his hind legs were so spread 
in his gallop, that a wheelbarrow might have been driven between them. King Herod, another famous horse, which was generally, though not like Eclipse uniformly, successful, is chiefly celebrated for his progeny; his immediate descendants having gained to their owners above two hundred thousand pounds."

The Horse's Many marvellous stories are told of the enEndurance. durance of the horse. Sir John Malcolm says, "Small parties of Toorkomans, who ventured several hundred miles into Persia, used both to advance and retreat at the average of nearly one hundred miles a day. They train their horses for these expeditions as we should do for a race, and describe him when in a condition for a foray by saying that his flesh is marble. When I was in Persia, a horseman mounted upon a Toorkoman horse, brought a packet of letters from Shiraz to Teherary, which is a distance of five hundred miles, within six days." Almost equally remarkable records are held by English horses, but the invention of the locomotive has done away with the necessity for such trying expeditions in civilized countries, and the horse is trained more for speed and strength than for such long distance efforts. M. de Pages in his travels round the world, tells a remarkable story of the endurance of the horse. when out of his natural element; he says, "I should have found it difficult to give it credit had it not happened at this place (the Cape of Good Hope) the evening before my arrival; and if, besides the public notoriety of the fact, I had not been an eyewitness of those vehement emotions of sympathy, blended with admiration, which it had justly excited in the mind of every individual at the Cape. A violent gale of wind setting in from north and north west, a vessel in the road dragged her anchors, was forced on the rocks and bulged; and, while the greater part of the crew fell an immediate sacrifice to the waves, the remainder were seen from the shore struggling for their lives, by clinging to the different 
pieces of the wreck. The sea ran dreadfully high, and broke over the sailors with such amazing fury, that no boat whatever could venture off to their assistance. Meanwhile a planter, considerably advanced in life, had come from his farm to be a spectator of the shipwreck; his heart was melted at the sight of the unhappy seamen, and knowing the bold and enterprising spirit of his horse, and his particular excellence as a swimmer, he instantly determined to make a desperate effort for their deliverance. He alighted and blew a little brandy into his horse's nostrils, and again seating himself in the saddle, he instantly pushed into the midst of the breakers. At first both disappeared, but it was not long before they floated on the surface, and swam up to the wreck; when taking with him two men, each of whom held by one of his boots, he brought them safe to shore. This perilous expedition he repeated no seldomer than seven times, and saved fourteen lives; but, on his return the eighth time, his horse being much fatigued, and meeting a most formidable wave, he lost his balance and was overwhelmed in a moment. The horse swam safely to land, but his gallant rider was no more!"

The Horse's Many remarkable instances are recorded of the

Memory. exercise of the faculty of memory by horses. Colonel Smith mentions an instance of a horse which he had used for two years while in the army abroad, and which some years later made himself known to his old master with every demonstration of pleasure, though harnessed to a mail coach. "That the horse remembers the scenes and transactions of past times," says Captain Brown, "is proved from every day's experience. It enters familiarly into its usual abode; inclines to stop at its ordinary haltingplace; prefers a journey which it has formerly taken, and falls readily into an occupation to which it has been accustomed. It seeks the fields in which it has formerly pastured, and has been known long afterwards to repair to the scenes 
of its earlier days. A horse belonging to a gentleman of Taunton strayed from a field at Corfe, three miles distant from thence. After a long and troublesome search, he was discovered on a farm at Branscombe, in Devon, a distance of twenty-three miles, being the place where he was foaled, although it is certain that the animal had not been there for ten years, during the whole of which time he had been in the possession of the gentleman who then owned him." Horses seem to have a similar sense of locality to that for which dogs are so famous. A horse will find its way home when its master cannot see a yard before him, instances being recorded of parties lost in the snow which covered all tracks, who only saved their lives by letting a horse loose and following him. Captain Brown gives two instances of horses who on becoming ill, found their way to the veterinary surgeon, who had previously treated them, entirely of their own accord. Instances are recorded also of Cavalry horses, who, on hearing thunder while out grazing, have mistaken it for the sound of cannon and who with great excitement have formed themselves into line and "presented the front of a field of war". Old Hunters who have become coach horses have been known upon hearing the hounds, at the moment of "changing" to dash after them with their hamess on their backs and riderless and guideless follow the hunt for hours. These are instances of the ruling passion strong in after life, or perhaps more correctly speaking of the force of habit, of which there are countless illustrations. Kosciusko had a horse which he once lent to a young man whom he employed upon a commission, but who on his return declared that he would never use the horse again unless also supplied with his master's purse; for said he, "as soon as a poor man on the road takes off his hat and asks charity the animal immediately stands still, and will not stir until something is bestowed upon the petitioner; and as I had no money about me I 
had to feign giving, in order to satisfy the horse and induce him to proceed." Such loyalty to habit, however interesting, is not always convenient, as the following, which I quote from "Anecdotes in Natural History" by the Rev. F. $O$. Morris will show.

"Towards the close of last century, when volunteers were first embodied in the different towns, an extensive line of turnpike road was in progress of construction in a part of the north. The clerk to the trustees upon this line used to send one of his assistants to ride along occasionally, to see that the contractors, who were at work in a great many places, were doing their work properly. The assistant, on these journeys, rode a horse which had for a long time carried a field officer, and, though aged, still possessed a great deal of spirit. One day, as he was passing near a town of considerable size which lay on the line of road, the volunteers were at drill on the common; and the instant the horse heard the drum he leaped the fence, and was speedily at that post in front of the volunteers which would have been occupied by the commanding officer of a regiment on parade or at drill; nor could the rider by any means get him off the ground until the volunteers retired to the town. As long as they kept the field the horse took the proper place of a commanding officer in all their manœuvres, and he marched at the head . of the corps into the town, prancing in military style as cleverly as his stiffened legs would allow him, to the great amusement of the volunteers and spectators, and to the no small annoyance of the clerk."

Perhaps no more amusing illustration of this force of habit could be found than that cited by Captain Brown of a Scotch lawyer who purchased a horse at Smithfield upon which to make a journey north. The horse was a handsome one and started well, but on reaching Finchley common, at a place where the road ran down a slight eminence, and up another, the lawyer met a clergyman driving a one horse chaise. 
"There was nobody within sight, and the horse by his manceuvre instantly discovered the profession of his former owner. Instead of pursuing his journey he laid his counter close up to the chaise and stopped it, having no doubt but his rider would embrace so fair an opportunity of exercising his profession. The clergyman seemed of the same opinion, produced his purse unasked, and assured the astonished lawyer, that it was quite unnecessary to draw his pistol as he did not intend to offer any resistance. The traveller rallied his horse, and with many apologies to the gentleman he had so innocently and unwillingly affrighted, pursued his journey. The horse next made the same suspicious approach to a coach, from the windows of which a blunderbuss was levelled with denunciations of death and destruction to the hapless and perplexed rider. In short, after his life had been once or twice endangered by the suspicions to which the conduct of his horse gave rise, and his liberty as often threatened by the peace-officers, who were disposed to apprehend him as a notorious highwayman, the former owner of the horse, he was obliged to part with the inauspicious animal for a trifle, and to purchase at a large price one less beautiful, but not accustomed to such dangerous habits."

The Horse's Of the larger quadrupeds the horse is said to Intelligence. be only second in intelligence to the Elephant, and many proofs could be given of the high standard of intelligence to which he sometimes attains. The Rev. F.O. Morris says, - "We knew a blind coach-horse that ran one of the stages on the great north road for several years, and so perfectly was he acquainted with all the stables, haltingplaces, and other matters, that he was never found to commit a blunder. He could never be driven past his own stable; and at the sound of the coming coach he would turn out, of his own accord, into the stable-yard. So accurate was his knowledge of time, that though half-a-dozen coaches halted at the same inn daily, he was never known to stir till the 
sound of his own coach, the "ten o'clock" was heard in the distance." The intelligence of this horse was somewhat circumscribed but it was perfect within its limits. Colonel Smith, as already quoted, says, "Bipeds who exercise authority over horses, often show little superiority of reason, and much less of temper." The way in which horses have preserved masters who have rendered themselves incapable of taking care of themselves is proof of this. A horse has been known to poke his nose in at a tavern door and shake his master by the shoulder, when he has been lingering too long over his potations. Another horse whose master from a similar cause was unable to keep his seat watched by his side in the road all night, and on being discovered by some Jabourers in the early morning vigorously resented their attempts to awaken him. Professor Kruger of Halle says, "A friend of mine was one dark night riding home through a wood, and had the misfortune to strike his head against the branch of a tree, and fell from his horse, stunned by the blow. The horse immediately returned to the house which they had left, about a mile distant. He found the door closed, and the family gone to bed. He pawed at the door till one of them, hearing the noise, arose and opened it, and to his surprise saw the horse of his friend. No sooner was the door opened than the horse turned round, and the man, suspecting there was something wrong, followed the animal, which led him directly to the spot where his master lay on the ground in a faint." A pony has been known to leap into a canal and save the life of a child in danger of drowning, and a cart horse to lift a child out of the road and place it carefully on the side walk before proceeding with his load. A remarkable illustration of the intelligence of the horse under circumstances in which most human beings would have lost all presence of mind, is quoted by Captain Brown. "In the month of April, I794, owing to a strong wind blowing contrary to the current of the river, the island Kroutsand, surrounded by the two 
branches of the Elbe, became entirely covered with water, to the great alarm of the horses, which, with some foals, had been grazing on it. They set up a loud neighing, and collected themselves together within a small space. To save the foals that were now standing up to their bellies in water seemed to be the object of their consultation. They adopted a method at once ingenious and effective. Each foal was arranged between horses, who pressed their sides together so as to keep them wedged up, and entirely free from injury from the water. They retained this position for six hours, nor did they relinquish their burden till the tide having ebbed and the water subsided, the foals were placed out of danger." Horse Play. Horse-play is a term which conveys the idea of rough if not brutal romping, and yet the horse can be gentle in its friendships and considerate in its dealings with weaker animals, and with children to a remarkable degree. White in his "Natural History of Selborne", tells of a curious friendship between a horse and a hen. "These two incongruous animals spent much of their time together in a lonely orchard, where they saw no creature but each other. By degrees an apparent regard began to take place between the two sequestered individuals; the fowl would approach the horse with notes of complacency, rubbing herself quietly against his legs, while the horse would look down with satisfaction, and move with the greatest caution and circumspection, lest he should trample on his diminutive companion." A similar friendship is recorded as between a horse and a sheep, whom circumstances threw much in company. Both gregarious animals and both failing of companionships of their own kind, they found solace in their loneliness in a beautiful if curious friendship. The gentleness of horses in dealing with children has often been remarked, even when within the confined limits of a stable they will use the utmost circumspection as to movements lest they should inadvertently tread upon their playfellows. Mr. Morris tells of a plough horse who 
was too tall for his little master to mount and who used to put his head down to the ground and allow the boy to bestride his neck and then by gently elevating his head help him to slide on to his back. Horses have been known to allow liberties to children that they would not allow to their elders, a remarkable illustration of which is given by Captain Brown. A hunter who always violently resented any attempt on the part of his grooms to trim his fetlocks, was once the subject of conversation in his master's house, when the master defied any man "to perform the operation singly." On the following day when passing through the stable-yard he was astonished and alarmed at seeing his youngest child, who had been an unnoticed listener to the conversation the night before, with a pair of scissors, clipping the fetlocks of the horse's hind legs, the horse watching the operation with evident satisfaction. It is, however, as between horses and dogs that the truest affinity appears to exist of animals of different families, and numerous anecdotes are told in illustration of these friendships. Captain Brown gives the following: "Doctor Smith, a practising physician in Dublin, had no other servant to take charge of his horse while at a patient's door, than a large Newfoundland dog; and between the two animals, a very good understanding subsisted. When he wished to pass to another patient without remounting, he needed but to give a signal to the pair, who followed him in the most perfect good order. The dog also led the horse to the water, and would give him a signal to leap over a stream. While performing this on one occasion, the dog lost hold of the reins, when the horse, having cleared the leap, trotted back to the dog, who resumed the reins."

" A gentleman in Bristol had a greyhound which slept in the same stable, and contracted a very great intimacy with a fine hunter. When the dog was taken out the horse neighed wistfully after him; he welcomed him home with a neigh; the greyhound ran up to the horse and licked him; 
the horse, in return, scratched the greyhound's back with his teeth. On one occasion, when the groom had the pair out for exercise, a large dog attacked the greyhound, bore him to the ground, and seemed likely to worry him, when the horse threw back his ears, rushed forward, seized the strange dog by the back and flung him to a distance which the animal did not deem it prudent to make less."

The horse's sympathy with his own kind must, however, not pass without mention. Horses have been known to masticate food for their toothless companions, an instance being recorded by $\mathrm{M}$. de Boussanelle, a cavalry officer, of a horse belonging to his company who was fed for two months in this way by the horses stationed on either side of him. Whether the horses in the following case were actuated by sympathy or fear, the story deserves to be retold for its extreme pathos. When Sir John Moore's soldiers embarked after the battle of Corunna, orders were given that the troop horses should be shot, rather than that they should fall into the hands of the enemy. "These horses," says Colonel Smith, "witnessing their companions fall one after another, stood trembling with fear, and by their piteous looks seemed to implore mercy from the men who had been their riders, until the duty imposed upon the dragoons who had been intrusted with the execution of the order became unbearable, and the men turned away from the task with scalding tears: hence the French obtained a considerable number unhurt, and among them several belonging to officers who, rather than destroy them, had left their faithful chargers with billets attached recommending them to the kindness of the enemy."

The Ass. The ass is an animal which seems to be more than ordinarily affected by its surroundings and treatment. In eastern countries where it is well cared for, and employed in the service of the rich, it rises to the occasion and becomes both graceful and spirited in action and elegant and refined in appearance: in the west where it is discarded for the sake 
of the horse, and used almost solely as a beast of heavy burden, often suffering great cruelty and hardship, it seems to lose spirit and become dull and obstinate, as people do who, crushed by hard circumstances, lose hope. The ass has an ancient and honourable history which dates back apparently as far as that of the horse. He is mentioned alike by sacred and profane writers, Job and Homer making flattering reference to him. In Syria and Persia, where he is cultivated, he attains to a much larger size than in the west, where he may be described as about two-thirds the size of the horse. In ancient times these animals fetched very large sums, sums which in our day would be considered very large for a horse, a stallion mentioned by Pliny realising a sum exceeding $£_{3000}$. "No domestic animal," says Colonel Smith, "in proportion to its bulk, can carry a greater weight, or continue to labour longer without sustenance. The, ass is emphatically the poor man's horse in every country; and if care were taken of the breed, and well selected animals imported from Arabia, a very useful and handsome race might be reared." Though the ordinary ass is slow and obstinate, his eastern cousin is both fleet and obedient, and remarkable feats have been performed by half breeds. A half-bred, Spanish and English, of twelve and a half hands high, belonging to Mr. Wilson of Ipswich, drew a light gig from Ipswich to London and back again, a distance of 140 miles, in two days. $\mathrm{He}$ is said to have maintained a pace little short of that of a good gig horse and to have performed the whole journey with ease, finishing it without whip, at the rate of seven miles an hour. Though patient above most animals, the ass will sometimes turn like the proverbial worm, and instances are known in which he has adopted the offensive with effect. Some years ago, a bull dog which had been set on to an ass, was caught by the latter in his teeth, carried to the river Derwent and held under water until he was drowned. Donkeys have often been known after enduring great provocation from boys 
to turn on their assailants and put them to speedy and anxious flight.

The Ragacity Dull though he appears to be, the ass show of the Ass. himself on occasion to be possessed of no little invention in matters that concern his liberty and comfort. His aptitude for lifting latches and drawing bolts has often been observed. Mr. Fuller describes the actions of an ass he saw, who put his head sideways between the bars of a gate and turning it into its normal position lifted the gate over the latch and pushed it forward, withdrawing his head after he had opened the gate and proceeding to enjoy the dainties of the field into which he had thus effected an entrance. A still more remarkable instance is given by $\mathrm{Mr}$. East who says: "While living on the Sussex coast, I had myself a very fine donkey, which was a remarkably docile and knowing animal. $\mathrm{He}$ was the constant companion of my children in their rambles on the downs, and on those occasions seemed to think he had a right to share in all the eatables and drinkables, and would do so most readily, whether cakes, apples, oranges, sweetmeats, milk, or even tea; ginger-beer being the only exception. With this he was thoroughly disgusted, in consequence of the cork, which had been expelled from the bottle with the usual loud report, having struck him on the nose. This he never forgot; but would quickly march off whenever a ginger-beer bottle was produced. But his cleverness and cunning were more especially shown in the following incident:-His lodging-place at night was a small, open shed, whence he had free access to a yard; but not, of course, to the kitchen-garden which adjoined it. The latter was separated from the yard by a wall and door, fastened securely, as we imagined, by two bolts and an ordinary latch. We were, however, surprised to find that the door had been unfastened during the night, while the footprints of the donkey on the garden walks and beds too plainly told who had been the trespasser. Still we 
could hardly suppose he could have drawn the bolts and let himself in, especially as the upper bolt was fixed at a considerable height. This, however, proved to have been the case; for my bedroom overlooking the yard and garden, I one night watched at the window, and distinctly saw master donkey, reared on his hind legs, unfastening the upper bolt with his nose or mouth. He then withdrew the lower one, lifted the latch, and walked quietly into the garden. In a few minutes I further observed him returning to his shed with a large bunch of carrots, which he deposited in his shed, and then went back-not, certainly, to bolt, but to latch the door; after which he leisurely set about munching his slily acquired booty. Before putting a final stop to these proceedings, I gave several of 'my neighbours, who were incredulous upon the subject, an opportunity of witnessing them. And at these times his sagacity was further evinced by the fact that he would never commence his operations until after the light had been extinguished at the bedroom window."

The Instinct The sense of locality so conspicuous in the of the Ass. dog, the cat and the horse is also possessed in a remarkable degree by the ass, as the following story told by Captain Brown will show. "In 1816 , an ass belonging to Captain Dundas was shipped on board the Ister, bound from Gibraltar to Malta. The vessel struck on a sand-bank off the Point de Gat, and the ass was thrown overboard into a sea which was so stormy that a boat that soon after left the ship was lost. In the course of a few days, when the gates of Gibraltar were opened in the morning, the guard was surprised by the same ass which had so recently been removed, presenting itself for admittance. On entering, it proceeded immediately to the stable which it had formerly occupied. The ass had not only swum to the shore, but found its own way from Point de Gat to Gibraltar, a distance of more than two hundred miles, through a mountainous and intricate country intersected by streams, which it had never 
passed before-but which it had now crossed so expeditiously that it must have gone by a route leading the most directly to Gibraltar."

The Trained The ass like many other animals is capable

Ass. of being trained to perform many tricks, advantage of which seems to have been taken long before our time, as the following quoted by Captain Brown will show. John Leo, in a book printed as early as 1556 , says, "when the Mahometan worship was over, the common people of Cairo resorted to the foot of the suburbs called Bed-Elloch to see the exhibition of stage-players and mountebanks, who teach camels, asses, and dogs to dance. The dancing of the ass is diverting enough; for after he has frisked and capered about, his master tells him, that the Soldan, meaning to build a great palace, intends to employ all the asses in carrying mortar, stones, and other materials; upon which the ass falls down with his heels upwards, closing his eyes, and extending his chest, as if he were dead. This done, the master begs some assistance of the company, to make up the loss of the dead ass; and having got all he can, he gives them to know that truly his ass is not dead, but only being sensible of his master's necessity, played that trick to procure some provender. He then commands the ass to rise, who still lies in the same posture, notwithstanding all the blows he can give him, till at last he proclaims, by virtue of an edict of the Soldan, all are bound to ride out next day upon the comeliest asses they can find, in order to see a triumphal show, and to entertain their asses with oats and Nile water. These words are no sooner pronounced, than the ass starts up, prances, and leaps for joy. The master then declares, that his ass has been pitched upon by the warden of his street, to carry his deformed and ugly wife; upon which the ass lowers his ears, and limps with one of his legs, as if he were lame. The master, alleging that his ass admires handsome women, commands him to single out the prettiest lady in 
the company; and accordingly, he makes his choice by going round, and touching one of the prettiest with his head, to the great amusement of the company."

The Mruleand The Mule and the Hinny, are the off-spring the Hinny. of the ass and the horse and combine to some extent the qualities of both. The mule has the sure-footedness of the ass, and the size and appearance of the horse. His history dates back to classical and Biblical times, and mention is made of him both in the Iliad and in the Bible. In the East he is still trained to useful service, and in England he is used in tramways and road cars. . The Spanish mules are trained to understand the calls of their driver who directs their course by shouting from the box.

The Zebra. The Zebra resembles the horse in shape, and in size stands half way between the horse and the ass. $\mathrm{He}$ belongs to Central Africa, and hitherto has resisted all attempts to tame him for practical use. $\mathrm{He}$ is a beautiful animal, handsomely marked with black and white stripes all over the body, and black and white rings round the legs. Burchell's Zebra which belongs to the Cape of Good Hope, is similar, but has white legs. The Quagga of Southern Africa has a brown coat striped with black, a white waistcoat, and white stockings. Zebras have been half tamed, when kept in menageries, but lack the instinctive docility of the horse.

The Tapir. The next family we have to deal with is the family of the Tapiridee, in which there are two genera and six species. The Tapir is a large and powerful animal standing from five to six feet in height and inhabiting the warmer regions of South America. It is nocturnal in its habits and feeds on water-melons, gourds, and other fruits and vegetables. It frequents the water and can remain below the surface for a long time. Its hide is very thick and its senses of sight, hearing, and smell very acute. Its most characteristic feature is as hort mobile probos-cis which enables it to seize hold of boughs and fruits when in search of food. 
The Rev. J. G. Wood says, "Its disposition is gentle, but when annoyed, it sometimes rushes at its antagonist, and defends itself vigorously with its powerful teeth. The jaguar frequently springs on it, but it is often dislodged by the activity of the Tapir, who rushes through the bushes immediately that it feels the claws of its enemy, and endeavours to brush him off against the thick branches." The Tapir is easily tamed and even domesticated, though it must be admitted it makes a somewhat huge pet. It is intelligent and in its own way shows appreciation of kindness and attachment to its owner. This family has sometimes been regarded as a link between the Elephant and the Rhinoceros, but in the classification here followed the Elephant forms a separate order; the Tapir and the Rhinoceros complete the sub-order of Perissodactyla or odd-toed, hoofed animals. The Indian Tapir is somewhat larger than his American cousin and is distinguished by the greyish-white colour of his hind quarters, which gives him the appearance of bearing a white horse cloth on his loins.

The The Rhinoceros is found in both Asia and Rhinoceros. Africa, and is classified by Dr. Gray in four genera. Of these the Indian Rhinoceros, the Rhinoceros of Sumatra, and the Mahoohoo of South and Central Africa are representatives. Mr. Gordon Cumming says, "There are four varieties in South Africa, distinguished by the Bechuanas by the names of the Borèle or black rhinoceros, the Keitloa or two-horned black rhinoceros, the Muchocho or common white rhinoceros and the Kobaoba or long-horned white rhinoceros. Both varieties of the black rhinoceros are extremely fierce and dangerous, and rush headlong and unprovoked upon any object which attracts their attention. Their horns are much shorter than those of the other varieties, seldom exceeding eighteen inches in length. They are finely polished with constant rubbing against trees. The skull is remarkably formed, its most striking feature being the 


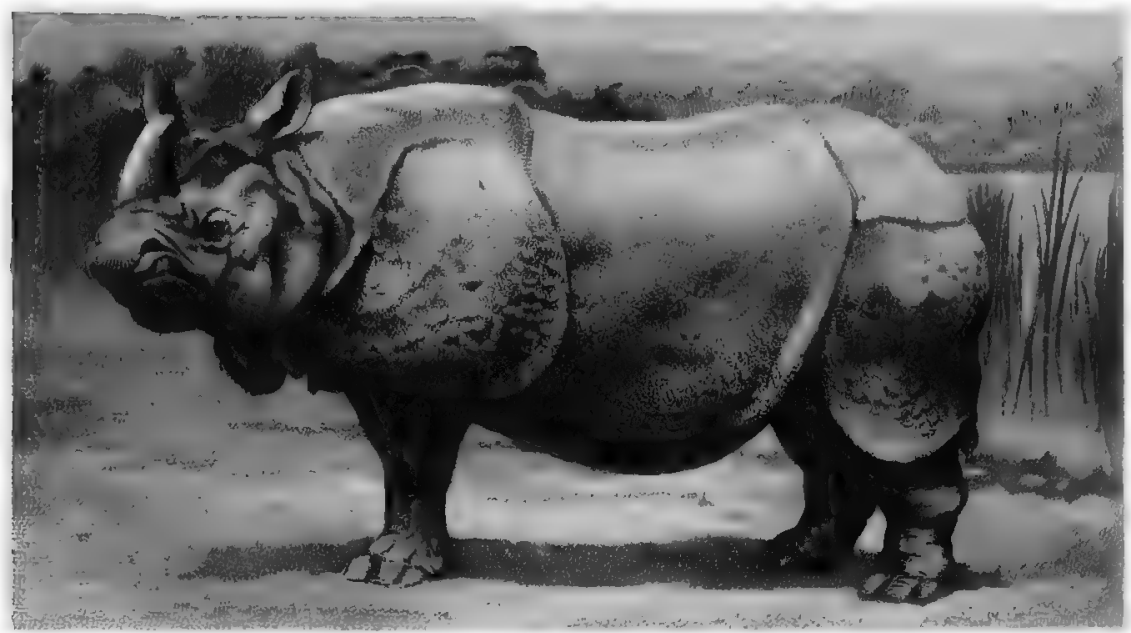

INDIAN RHINOCEROS

(Rhinocoros unicornis)

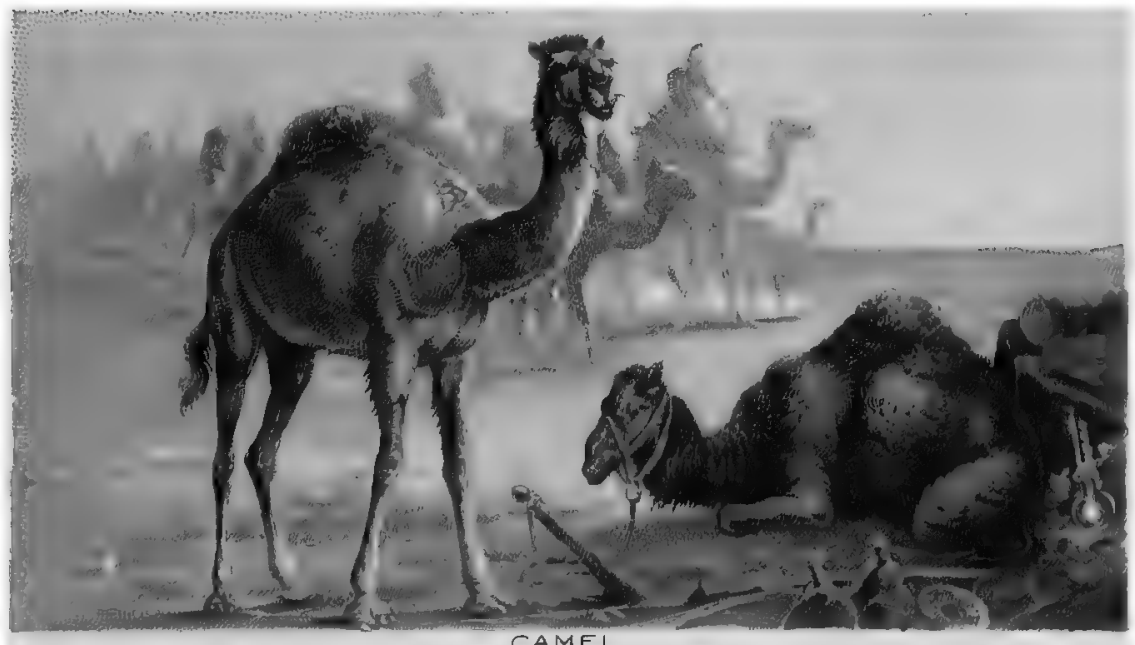


Digitized by Microsofte 
tremendous thick ossification in which it ends above the nostrils. It is on this mass that the horn is supported. The horns are not connected with the skull, being attached merely by the skin, and they may thus be separated from the head by a sharp knife. They are hard and perfectly solid throughout. The eyes of the rhinoceros are small and sparkling and do not readily observe the hunter, provided he keep to leeward of them. The skin is extremely thick, and only to be penetrated by bullets hardened with solder." "During the day the rhinoceros will be found lying asleep or standing indolently in some retired part of the forest, or under the base of the mountains, sheltered from the power of the sun by some friendly grove of umbrella-topped mimosas. In the evening they commence their nightly ramble, and wander over a great extent of country." "The black rhinoceros is subject to paroxysms of unprovoked fury, often ploughing up the ground for several yards with its horns, and assaulting large bushes in the most violent manner." "The rhinoceros is supposed by many, and by myself among the rest, to be the animal alluded to by Job, Chap. $\mathrm{xxxIx}$, verses Io and II, where it is written: 'Canst thou bind the unicorn with his band in the furrow? or will he harrow the valleys after thee? Wilt thou trust him because his strength is great? or wilt thou leave thy labour to him ?" "All the four varieties delight to roll and wallow in mud, with which their rugged hides are generally encrusted. Both varieties of the black rhinoceros are much smaller and more active than the white, and are so swift that a horse with a rider on his back can rarely overtake them. The two varieties of the white rhinoceros are so similar in habits, that the description of one will serve for both; the principal difference consisting in the length and set of the anterior horn; that of the muchocho averaging from two to three feet in length, and pointing backwards; while the horn of the Kobaoba often exceeds four feet in length, and inclines forward from the 
nose at an angle of $45^{\circ}$. The posterior horn of either species seldom exceeds six or seven inches in length. Both these varieties attain an enormous size, being the animals next in magnitude to the elephant. They feed solely on grass, carry much fat, and their flesh is excellent, being preferable to beef."

Rhinoceros Mr. Gordon Cumming gives several graphic Furting. descriptions of his experiences with the rhinoceros, in his "Hunting Adventures in South Africa", from which work the foregoing description of the several species is taken. On one occasion after following a huge white rhinoceros, which, however, escaped him, he says, "I found myself on the banks of the stream beside which my waggons were outspanned. Following along its margin, I presently beheld a bull of the borèlé, or black rhinoceros, standing within a hundred yards of me. Dismounting from my horse, I secured him to a tree, and then stalked within twenty yards of the huge beast, under cover of a large strong bush. Borèlé, hearing me advance, came on to see what it was, and suddenly protruded his horny nose within twenty yards of me. Knowing well that a front shot would not prove deadly, I sprang to my feet and ran behind the bush. Upon this the villain charged, blowing loudly, and chased me round the bush. Had his activity been equal to his ugliness my wanderings would have terminated here, but by my superiority I had the advantage in the turn. After standing a short time eyeing me through the bush... he wheeled about, leaving me master of the field." This was not the only nor even the narrowest escape experienced by Mr. Gordon Cumming when hunting this enormous beast. On another occasion he says :- "Having proceeded about two miles with large herds of game on every side, I observed a crusty looking old bull borèlé or black rhinoceros, cocking his ears one hundred yards in advance. He had not observed us; and soon after he walled slowly towards us, and stood broadside, eating some wait-a-bit 
thorns within fifty yards of me. I fired from my saddle, and sent a bullet in behind his shoulder, upon which he rushed forward about one hundred yards in tremendous consternation, blowing like a grampus, and then stood looking about him. Presently he made off. I followed, but found it hard to come up with him. The chase led through a large herd of wildebeests, zebras, and springboks, which gazed at us in utter amazement. At length I fired my second barrel, but my horse was fidgety, and I missed. I continued riding alongside of him, expecting in my ignorance, that at length he would come to bay, which rhinoceroses never do; when suddenly he fell flat on his broadside on the ground, but, recovering his feet resumed his course as if nothing had happened. Becoming at last annoyed at the length of the chase, as I wished to keep my horse fresh for the elephants, and being indifferent whether I got the rhinoceros or not, I determined to bring matters to a crisis, so spurring my horse, I dashed ahead, and rode right in his path. Upon this the hideous monster instantly charged me in the most resolute manner, blowing loudly through his nostrils; and although I quickly wheeled about to my left, he followed me at such a furious pace for several hundred yards, with his horrid horny snout within a few yards of my horse's tail, that my little bushman, who was looking on in great alarm, thought his master's destruction inevitable. It was certainly a very near thing; my horse was extremely afraid and exerted his utmost energies on the occasion. The rhinoceros, however, wheeled about and continued his former course, and I, being perfectly satisfied with the interview which I had already enjoyed with him, had no desire to cultivate his acquaintance any further, and accordingly made for the camp."

The Tame Some species of the rhinoceros, if not all, seem Rhinoceros. to be tamable. The Indian variety distinguished by the thick folds of heavy garment-like skin, which hang from his shoulders, haunches and thighs, has been trained 
to exercise the same quiet patience which distinguishes the elephant. The paroxysms of rage which Mr. Gordon Cumming describes the African variety as venting upon a harmless bush, or employing in tearing up the earth, have been known to seize those specimens which have been imported into England, as the following account of the rhinoceros, exhibited at Exeter Change, published in the "Philosophical Transactions for 1822," will show. "This animal about a month after it came, endeavoured to kill the keeper, and nearly succeeded. It ran at him with the greatest impetuosity, but, fortunately, the horn passed between his thighs, and threw the keeper on its head; the horn came against a wooden partition, into which the animal forced it to such a depth as to be unable for a minute to withdraw it, and, during this interval, the man escaped. Frequently, (more especially in the middle of the night), fits of frenzy came on; and, while these lasted, nothing could control its rage, the rhinoceros running with great swiftness round the den, playing all kinds of antics, making hideous noises, knocking everything to pieces, disturbing the whole neighbourhood, and then, all at once, becoming quiet. While the fit was on, even the keeper durst not make his approach. The animal fell upon its knee to enable the horn to be borne upon any object. It was quick in all its motions, ate voraciously all kinds of vegetables, appearing to have no selection. They fed it on branches of willow. Three years' confinement made no alteration in its habits." The rhinoceros is said to live for a hundred years.

The Hippo. The Hippopotamus introduces the second subpotamus. order of the hoofed animals, the Artiodactyla, animals having an even number of toes. There is but one genus of the Hippopotamus and two species, the Hippopotamus of the great rivers of Southern Africa, and the Liberian Hippopotamus of the West. The Hippotamus is gregarious, congregating in the deep shady pools and on the sandy 
banks of the shallow rivers of its native land. It attains to ten or eleven feet in length, and to five feet, or more, in height, being the next largest animal to the rhinoceros and the elephant. $\mathrm{He}$ is a powerful beast and has been known to attack and capsize boats, though when hunted he usually sinks to the bottom of the river where he is able to remain five or six minutes without rising to the surface for breath. The form of his head enables him to lift his eyes and his nostrils above the water at the same time without exposing more than a slight portion of his head. Thus, while taking in breath to sustain him while out of the reach of his enemies, he can watch their movements and determine his course below. His hide is very thick and strong and is, therefore, very useful for a variety of purposes, while his tusks furnish the dentist with the material to supply human deficiencies.

The Haunt Mr. Gordon Cumming gives the following of the vivid description of the haunt of the Hippopotami. Hippopotami. "The next day I rode down the river to seek sea-cows, taking as usual my double-barrelled rifles. We had proceeded about two miles when we came upon some most thoroughly beaten, old established hippopotamus paths, and presently, in a broad, long, deep, and shaded pool of the river, we heard the sea-cows bellowing. There I beheld one of the most wondrous and interesting sights that a sportsman can be blessed with. I at once knew that there must be an immense herd of them, for the voices came from the different parts of the pool; so creeping in through the bushes to obtain an inspection, a large sandy Island appeared at the neck of the pool, on which stood several large shady trees. The neck of the pool was very wide and shallow, with rocks and large stones; below, it was deep and still. On a sandy promontory of this Island stood about thirty cows and calves, whilst in the pool opposite, and a little below them, stood about twenty more sea-cows, with their heads and backs above water. About fifty yards further 
down the river again, showing out their heads, were eight or ten immense fellows, which I think were all bulls; and about one hundred yards below these in the middle of the stream stood another herd of about eight or ten cows with calves and two huge bulls. The sea-cows lay close together like pigs; a favourite position was to rest their heads on their comrade's sterns and sides. The herds were attended by an immense number of the invariable rhinoceros birds, which on observing me did their best to spread alarm throughout the hippopotami. I was resolved to select, if possible, a firstrate old bull out of this vast herd, and I accordingly delayed firing for nearly two hours, continually running up and down behind the thick thorny cover, attentively studying the heads. At length I determined to go close in and select the best head out of the eight or ten bulls which lay below the cows. I accordingly left the cover, and walked slowly forward in full view of the whole herd to the water's edge, where I lay down on my belly and studied the heads of these bulls. The cows on seeing me splashed into the water and kept up a continual snorting and blowing till night set in. After selecting for a few minutes I fired my first shot at a splendid bull and sent the ball in a little behind the eye. $\mathrm{He}$ was at once incapacitated, and kept plunging and swimming round and round, wearing away down the pool, until I finished him with two more shots."

The Pig Pigs, hogs and peccaries form the next family Family. with which we have to deal. The Wild Boar which we may take first, is famous in classic history and European legends, and is celebrated both by ancient and modern poets. $\mathrm{He}$ is, or was common to Europe, Asia and Africa, and whether in the hunt or the banquet has always been highly esteemed. The boar hunt is an exciting chase, having all the elements of danger necessary to give it zest. Boars have been known to kill not only dogs, but horses and men with their powerful tusks, turning and rending them 
with great strength and ferocity. When in a wild state the boar is a dangerous and inconvenient neighbour, for he commits serious depredations upon the property of the peasant and the farmer. Bruce in his travels gives an illustration of this. He says: "We pitched our tent in a small plain by the banks of a quick clear running stream; the spot is called Mai-Shum. A peasant had made a very neat little garden, on both sides of the rivulet, in which he had sown abundance of onions and garlic, and he had a species of pumpkin which I thought was little inferior to a melon. This man guessed by our arms and our horses that we were hunters, and he brought us a present of the fruits of his garden, and begged our assistance against a number of wild boars, which carried havoc and desolation through all his labours, marks of which were, indeed, too visible everywhere.-Amongst us all we killed five boars, all large ones, in the space of about two hours; one of which measured six feet nine inches; and though he ran at an amazing speed near two miles, so as to be with difficulty overtaken by the horse, and was struck through and through with two heavy lances loaded at the end with iron, no person dared to come near him on foot, and he defended himself above half an hour, till having no other arms left, I shot him with a horse-pistol." The tusks of the wild boar are often a foot in length and his hide is so tough that small bullets have been found between the skin and the flesh of captured specimens.

The Common Authorities differ as to whether the domestic \#̈og. pig is derived from the wild species or not, but certain it is that the domestic hog under suitable circumstances, 'betrays wild instincts. Hogs have been known to hunt rabbits and poultry and attack lambs when temporarily free from restraint, and instances have been recorded in which the hog has attacked and killed its keeper. The hog grows to a great size, the measurements of one belonging to Mr. Lunton of Bodmain some years ago being nine feet in length and 
seven feet five inches in girth. Its weight was eight hundred and fifteen pounds. These limits have, however, often been exceeded, a hog bred in Cheshire measuring nine feet eight inches including tail, and standing four feet six inches in height. This animal weighed I,215 pounds when killed. Hampshire, Wiltshire, Berkshire, and Yorkshire have all fine breeds which supply the larders of the United Kingdom with prime bacon. The sucking pig has been deemed a dainty dish even from Roman times. The babiroussa belongs to Bouru and Celebes, and is gregarious. Its habits are similar to those of the wild hog, which the male rivals and even surpasses in size. It has tusks attached to both the upper and the lower jaw, which bend backwards with a graceful curve.

The Peccary. The Peccary belongs to South America where it is indigenous. There are two species, the Collared Peccary and the White-lipped Peccary. The collared peccary is a timid, inoffensive animal about three feet long, and distinguished by white bands which traverse the shoulders and meet at the neck. They associate in pairs or small families and live in holes and hollows. The white-lipped peccary herds in large numbers, migrating apparently in regular order in companies sometimes a thousand strong. These animals are very fierce when attacked, and the hunter has little chance of escaping them unless he can find shelter in a friendly tree. Many stories are told of hunters who have sought such asylum, and who have been kept treed many hours by peccaries who, regardless of the mortality of their comrades, have lingered round the trunk.

The Camel and The history of the Camel carries us back the Dromedary. to the age of the great patriarchs, and gives him some claim to be regarded as a patriarch himself. $\mathrm{He}$ belongs to Egypt and Arabia, where he is indispensable to the desert ranger, and where no longer found in a wild state, he takes rank as a domestic animal. His uses are several. As a beast of burden he is invaluable, while the milk of the 
female serves as an article of food, the surplus wool of his body as a material for rough woven cloth and his dung as excellent fuel. He is said by some to be docile and affectionate and by others to be dull and stupid, though harbouring the spirit of revenge. Probably like many other animals he will be found to reciprocate the treatment he receives in kindness as well as in cruelty. Some confusion exists in the popular mind as to distinctions between the Camel and the Dromedary, the number of the humps being said to differentiate the two. With regard to this Mr. Palgrave in his "Travels in Central and Eastern Arabia", says :- "The camel and the dromedary in Arabia are the same identical genus and creature, excepting that the dromedary is a high-bred camel, and the camel a low-bred dromedary; exactly the distinction which exists between a race-horse and a hack; both are horses, but the one of blood and the other not. The dromedary is the race horse of this species, thin, elegant, (or comparatively so) fine haired, light of step, easy of pace, and much more enduring of thirst than the woolly, thick-built, heavy-footed, ungainly and jolting camel. But both and each of them have only one hump, placed immediately behind their shoulders, where it serves as a fixing point for the saddle or burden. For the two humped beast-it exists, indeed, but it is neither an Arab dromedary nor camel; it belongs to the Persian breed called by the Arabs 'Bakhtee" or Bactrian."

The strength Like all animals in their native lands the camel and

Indurance shows remarkable adaptation to his environment. of the Camel. Water is scarce in the desert, so the ship of the desert, as he has been poetically called, is provided with a capacity for the storage of the precious fluid and is able to take in a several days' supply at one time. The camel is said to drink "fifty, sixty, or even a hundred pounds' weight" of water at one time, and then to go for three or four days without a fresh supply. Again food is scarce in the desert, and the herbage of a very coarse kind, but the camel is able 
to do with remarkably little food, if his size and the weight of his burden are taken into consideration, and he will browse contentedly upon such food as he finds by the wayside, supplemented by "a cake of barley, a few dates, or beans" from the hands of his master. "They are particularly fond," says a writer in "Tales of Animals", " of those vegetable productions, which other animals would never touch, such as plants which are like spears and daggers, in comparison with the needles of the thistle, and which often pierce the incautious traveller's boot." A camel can be purchased in Egypt for from thirty to fifty dollars, though the high bred dromedary will fetch a very much larger sum. The camel will carry from five hundred to eight hundred pounds' weight, but will not stir if loaded beyond his strength. He travels at a uniform rate of three miles an hour, but will keep-on at that rate for ten or twelve hours. The dromedary attains to a speed which the Arab compares to the speed of the wind.

The Camel Mr. Macfarlane says, “I have been told that and his the Arabs will kiss their Camels in gratitude and Mraster. affection, after a journey across the desert. I never saw the Turks either of Asia-Minor or Roumelia, carry their kindness so far as this; but I have frequently seen them pat their Camels when the day's work was done, and talk to them on their journey, as if to cheer them. The Camels appeared to me quite as sensible to favour and gentle treatment as a good bred horse is. I have seen them curve and twist their long lithe necks as their driver approached, and often put down their tranquil heads towards his shoulder. Near Smyrna, and at Magnesia and Sardes, I have occasionally seen a Camel follow his master like a pet dog, and go down on his knees before him, as if inviting him to mount. I never saw a Turk ill use the useful, gentle, amiable quadruped. But I have frequently seen him give it a portion of his own dinner, when, in unfavourable places, it had nothing but 
chopped straw to eat. I have sometimes seen the drivers on a hot day, or in passing a dry district, spirt a little water in the Camel's nostrils; they pretend it refreshes them."

Camol Riding. Camel riding is evidently an exercise which needs getting used to. Mrs. Bowdich says: "High saddles are placed on their backs; and it requires either to be used to them, or to be particularly careful, not to be half-killed at starting. The rider places himself in the saddle while the animals are kneeling; and when they raise their hindlegs, which they do first of all, they send the unprepared traveller forwards, and his breath is almost taken out of him by the blow which he receives upon his chest; then as they get upon their fore-legs they throw him back, so as to zndanger his spine. Their pace is at first very disagreeable, being so long and slouching."

Captain Riley describes his experiences as follows: "They placed me on the largest Camel I had yet seen, which was nine or ten feet in height. The Camels were now all kneeling or lying down, and mine among the rest. I thought I had taken a good hold, to steady myself while he was rising; yet his motion was so heavy, and my strength so far exhausted, that I could not possibly hold on, and tumbled off over his tail. Turning entirely over, I came down upon my feet, which prevented my receiving any material injury, though the shock to my frame was very severe."

A Camel's Mr. Palgrave who combats the idea of the Revenge. camel's docility, unless stupidity may be taken as its synonym, gives a painful illustration of the savagery to which the camel may be provoked by cruel treatment, though we doubt if the elephant who is proverbial for his docility would stand the brutality to which the camel is sometimes treated. "A lad of about fourteen, had conducted a large camel laden with wood from one village to another, half an hour's distance or so. As the animal loitered or turned out of the way, its conductor struck it repeatedly, and harder 
than it seems to have thought he had any right to do, but not finding the occasion favourable for taking immediate quits, it 'bode its time', nor was that time long in coming. A few days later the same lad had to re-conduct the beast, but unladen, to his own village. When they were about half way on the road, and at some distance from any habitation, the camel suddenly stopped, looked deliberately round in every direction, to assure itself that no one was in sight, made a step forward, seized the unlucky boy's head in his monstrous mouth, and lifting him up in the air, flung him down again upon the earth with the upper part of his skull completely torn off, and his brains scattered on the ground. Having thus satisfied his revenge, the brute quietly resumed his pace towards the village as though nothing were the matter, till some men, who had observed the whole, though unfortunately at too great a distance to be able to afford timely help, came up and killed it."

The Terrors Terrible stories are told of the sufferings someof the Desert. times experienced by camels and Arabs alike on desert journeys. Burckhardt gives the following narrative which is quoted by Captain Brown. "In the month of August, a small caravan prepared to set out from Berber to Daraou. They consisted of five merchants and about thirty slaves, with a proportionate number of camels. Afraid of the robber Naym, who at that time was in the habit of waylaying travellers about the wells of Nedjeym, and who had constant intelligence of the departure of every caravan from Berber, they determined to take a more easterly road, by the well of Owareyk. They had hired an Ababde guide, who conducted them in safety to that place, but who lost his way from thence northward, the route being little frequented. After five days' march in the mountains, their stock of water was exhausted, nor did they know where they were. They resolved, therefore, to direct their course towards the setting sun, hoping thus to reach the Nile. After experiencing two 
days' thirst, fifteen slaves and one of the merchants died; another of them, an Ababde, who had ten camels with him, thinking that the animals might know better than their masters where water was to be found, desired his comrades to tie him fast upon the saddle of his strongest camel, that he might not fall down from weakness, and thus he parted from them, permitting his camels to take their own way; but neither the man nor his camels were ever heard of afterwards. On the eighth day after leaving Owareyk, the survivors came in sight of the mountains of Shigre, which they immediately recognized; but their strength was quite exhausted, and neither men nor beasts were able to move any farther. Lying down under a rock, they sent two of their servants, with the two strongest remaining camels, in search of water. Before these two men could reach the mountain, one of them dropped off his camel, deprived of speech, and able only to move his hands to his comrade as a sign that he desired to be left to his fate. The survivor then continued his route; but such was the effect of thirst upon him, that his eyes grew dim, and he lost the road, though he had often travelled over it before, and had been perfectly acquainted with it. Having wandered about for a long time, he alighted under the shade of a tree, and tied the camel to one of its branches: the beast, however, smelt the water, (as the Arabs express it) and, wearied as it was, broke its halter, and set off galloping in the direction of the spring, which, as afterwards appeared, was at half an hour's distance. The man, well understanding the camel's action, endeavoured to follow its footsteps, but could only move a few yards; he fell exhausted on the ground, and was about to breathe his last, when Providence led that way from a neighbouring encampment, a Bisharye Bedouin, who, by throwing water upon the man's face, restored him to his senses. They then went hastily together to the water, filled the skins, and, returning to the caravan, had the good fortune to find the 
sufferers still alive. The Bisharye received a slave for his trouble."

The Ilama. The Llamas are classified as members of the Camel Family of which they are the second genus. The Vicuna (Llama vicugna) of the Peruvian Andes is one of these. It is a very beautiful animal, combining, as Professor Cunningham points out, to some extent the characteristics of the camel, the deer and the goat. Its neck is long and slender and carried with a graceful curve, and its legs are slight and elegant, its wool fine and silky. It is a timid animal and very wary of the approach of danger, seeking safety in flight, though often falling a victim to the rapacity of the puma, or the necessities of the Patagonian Indians, who eat its flesh and clothe themselves in its skin. The Llama, (Llama peruana) and the Alpaca (Llama pacos) are other species of this family. The former is used by the Peruvians as a beast of burden, as it will carry from a hundred-weight to a hundred weight and a half for fifteen or twenty miles a day. According to Mrs. Bowdich, at one time 300,000 of these animals were employed in carrying metal over the rugged mountain passes for the Potosi mines alone. Like the camel, it refuses to stir when overloaded, and continues to move at a slow uniform pace throughout the day. Like camels also, they are apt to fight among themselves, when the wool flies in an absurd way, and if not separated, they do each other serious injury. When offended with their driver they spit in his face, their saliva being particularly unpleasant. The Alpaca which is also domesticated is useful for its fleece.

The Deer. There are two families of Deer; that of the Mouse deer with its mouse-shaped head, and without horns, and that of the deer proper of which there are more than fifty species. There are five species of the mouse deer, genus Tragulus, all of which belong to Asia. They are found in Java, Penang, Sumatra, Borneo, Cambodia and Siam. The Indian Chevrotain (Tragulus meminna) is spotted. It 
belongs to Ceylon, though it is said to be common to the forests of all parts of southern India. Mrs. Bowdich says: "The smallest of the deer species lives in Ceylon; a lovely delicate creature, with lustrous eyes and of exquisite form. When full grown it is only ten inches high, fourteen long, and weighs about five pounds. Its throat, head and neck are all white; its body is grey, striped with black, and spotted at equal distances with yellow. Although very timid it is to be tamed; but if angry it kicks out its little hind legs and slender pointed hoofs with great violence. One which was domesticated, was placed on a dinner table, where it ran about and nibbled fruit from the dishes, answered to its name and returned the caresses which were bestowed upon it." The deer proper, genus cervus, is found all over Europe, Asia and America, one or two species belonging to the Mediterranean coasts of Africa. Of these the Red Deer, the Reindeer, the Moose or Ell, the Fallow Deer and the Roe buck are the better known species, all of which chew the cud, have a divided hoof, and shed their horns annually.

The Red The Red Deer (Cervus elaphus) is still found

Deer. in Scotland as well as in the forests of Europe and Asia and is commonly hunted for sport. The stag is a timid and apparently highly sensitive animal, but when brought to bay has often shown a strength and courage which has cost its hunters dear. It is one of the most beautiful animals in nature, and combines with its beauty powers of speed and endurance which are little short of the marvellous. Full grown it measures four feet six inches in height at the shoulders, and about five feet six inches in length. The hunting of the stag in England has been a royal sport for centuries, though owing to altered conditions it has fallen into disrepute of late years. The overcrowded state of the country near London, and the half tame character of the royal stags have rendered the performances of the Windsor stag hounds an exhibition more honoured in the breach than in the observance. It 
would be difficult indeed to find anything noble or enobling in the following account of a stag hunt quoted by Captain Brown with deprecation, from the pages of "The Sporting Magazine."

A stag "On Monday Nov. 20, 1820, the royal hounds met Hunt. at Stoke Common, Bucks, where a remarkably fine deer was turned out. The field was extremely numerous. The deer, at starting, showed great sport, taking, at full speed, through the enclosures, making towards Slough, and afterwards for Datchet, where he crossed the Thames, and then took to the right, and again crossed the river. The deer proceeded up a lane at the back of Eton College, running with great swiftness into the yard of Mr. Castles, pork butcher. He boldly proceeded through the house into the street, with a cur-dog at his heels; and crossing Windsor Bridge, to the bottom of Thames-street, actually ran up the Hundred Steps, a steep and winding ascent to the Castle. On his reaching the top, he made a pause, and then returned into Thames-street, many of the sportsmen having rode round into the Castle, with the object of heading him as he came up the steps. The stag crossed Windsor Bridge again with great swiftness, and passed down Eton, entered the shop of Mr. Levy, an orange merchant, making his way in different parts of the house, till he got into the kitchen, where he remained some time: a great crowd was collected round the house. On his leaving the kitchen, he passed through the back way into gardens. At this time, many hundreds of persons joined in the chase. This excellent deer, after having performed these extraordinary feats, and afforded a charming day's sport, was at last taken in attempting to leap over the high wall between Eton College and the Fifteen-arch Bridge." In the open country and in the olden time a stag hunt was, of course, a very different thing, though the hunting of so sensitive and so timid an animal as the stag could never be other than a cruel pastime. Of the speed and endurance of 
the stag a remarkable illustration will be found on page 127 . Many years ago the Duke of Cumberland thought to make trial of a stag's courage by placing him in an enclosure with an ounce, or hunting tiger, on Newmarket Heath. The enclosure was made by a net-work of about fifteen feet high, and the contest took place in the presence of some thousands of spectators. On seeing the stag, the ounce crouched down and prepared to spring, but the stag kept such a steady front that the ounce, turn as he would, was out-manœuvred by the stag and could not get a chance of turning his flank. After a long time the ounce was goaded to the attack by the order of the Duke, whereupon it leapt, not upon the stag but over the enclosure and among the people, immediately crossing the road and entering the wood opposite, where it fastened upon the haunches of a fallow deer.

The Tame Stags have been tamed and brought largely Stag. under control but they are said to be uncertain in their temper, probably from their timidity. Many years ago Lord Oxford trained four red deer stags to draw a phaeton, and Captain Brown tells an amusing story of an adventure which befell him while driving his unique team in the neighbourhood of Newmarket. It happened that as they were proceeding on the road to Newmarket they heard the cry of a pack of hounds and immediately the four stags made off at the top of their speed, followed by the hounds who had sighted them or scented them from a distance. The animals were quite beyond control, but on reaching Newmarket, they ran into the yard of the Ram Inn where Lord Oxford had been accustomed to take them, and they were safely housed in a barn when the pack of hounds came up. Stags have also been trained to play tricks of various kinds. A tame stag at one time marched with a Newfoundland dog; with the band of the 4 2nd Highlanders.

The Reindeer. The Reindeer belongs to the north of Europe Asia and America, where he is the chief source of comfort 
and wealth of the natives. In Lapland, as the author of "Tales of Animals" puts it, he supplies the place of the horse, the cow, the sheep, and the goat. "Alive and dead, the reindeer is equally subservient to their wants. When he ceases to exist, spoons are made of his bones, glue of his horns, bowstrings and thread of his tendons, clothing of his skin, and his flesh becomes a savoury food. During his life, his milk is converted into cheese, and he is employed to convey his owner over the snowy wastes of his native country. Such is the swiftness of the reindeer that two of them, yoked in a sledge, will travel a hundred and twelve English miles in a day." The reindeer will draw about $300 \mathrm{lbs}$. weight, though 250 lbs. is a sufficient average load. His ordinary pace is said to be about ten miles an hour and his powers of endurance are very great. His pace for a short distance is thus given by Pictet, who took the measurements and tested the speed of three animals yoked to light sledges. "The first deer performed 3089 feet, 9 inches, in two minutes, being at the rate of nearly ig English miles in an hour, and thus accomplishing 25 feet, 9 inches, in every second. The second did the same in three minutes; and the third and last deer, in three minutes and twenty-six seconds. The ground in this race was nearly level." The reindeer is gregarious in its wild state, and retains its social instinct when in a state of domestication. When travelling, the hindmost animals follow their leader with dogged persistency, even though the leader may make a circuit which the followers might avoid by taking a direct cut. Nor will they accept the guidance of their drivers in such cases and if dragged out of their course by main force will return to it as soon as the force is removed. In his own way, however, the reindeer will follow unerringly though his leader may be out of sight, moving along with his nose close to the ground and tracing the way by his scent, which is very keen. The reindeer is much troubled in the summer time by the attacks of small flies, De Broke says, "The poor animal is thus 
tormented to such a degree, that the Laplander, if he were to remain in the forests during the months of June, July, and August, would run the risk of losing the greater part of his herd, either by actual sickness, or from the deer fleeing of their own accord to mountainous situations to escape the gad-fly. From these causes, the Laplander is driven from the forests to the mountains that overhang the Norway and Lapland coasts, the elevated situations of which, and the cool breezes from the Ocean, are unfavourable to the existence of these troublesome insects, which, though found on the coast, are in far less considerable numbers there, and do not quit the valleys; so that the deer, by ascending the highlands, can avoid them." Reindeer are extremely timid when hunted, but if the hunter can get sufficiently near to strike panic into a herd they seem to lose all sense but that of fear, and are easily captured in numbers. 'Writing of the North American Reindeer, Sir John Richardson says:- "The Chippewayans, the Copper Indians, the Dog-ribs, and Hare Indians of the Great Bear Lake, would be totally unable to inhabit their barren grounds, were it not for the immense herds of this deer that exist there. Of the caribou horns they form their fish spears and hooks; the hide, dressed with the fur on, is excellent for winter clothing, and supplies the place both of blanket and feather bed to the inhabitants of these arctic wilds." Captain Franklin gives the following description of the manner in which the Dog-rib Indians kill the reindeer. "The hunters go in pairs, the foremost man carrying in one hand the horns and part of the skin of the head of a deer, and in the other a small bundle of twigs, against which he, from time to time, rubs the horns, imitating the gestures peculiar to the animal. His comrade follows, treading exactly in his footsteps, and holding the guns of both in a horizontal position, so that the muzzles project under the arms of him who carries the head. Both hunters have a fillet of white skin round their foreheads, and the foremost has a strip of the 
same round his wrists. They approach the herd by degrees, raising their legs very slowly, but setting them down somewhat suddenly, after the manner of a deer, and always taking care to lift their right or left feet simultaneously. If any of the herd leave off feeding to gaze upon this extraordinary phenomenon, it instantly stops, and the head begins to play its part by licking its shoulders, and performing other necessary movements. In this way the hunters attain the very centre of the herd without exciting suspicion, and have leisure to single out the fattest. The hindmost man then pushes forward his comrade's gun, the head is dropped, and they both fire nearly at the same instant."

The Moose The Moose or Elk is the largest of the Deer or rilk. kind, and often attains to and even exceeds the size and bulk of the largest horses. $\mathrm{He}$ is less graceful than other members of his family, having a short thick neck, necessary perhaps to sustain his huge antlers, which sometimes reach five feet in length and weigh as much as sixty pounds. He escapes the torment of insects by taking to the water, in which he is an expert swimmer. Like the other animals of the Deer kind he sheds his horns annually. Year by year these huge growths increase in breadth and in the number of branches they bear, until there are sometimes as many as twenty on each horn. He is docile and easily tamed, and has been broken to run in harness. The Elk occupies much the same geographical area as the reindeer, though not travelling so far north.

The Fallow The Fallow Deer (Dama vulgaris) is smaller Deer and the than the stag, but similar to it in colour, form, Roebuck. and habit. It is this species which is domesticated and kept in the parks of the wealthy in England. Fallow Deer often quarrel among themselves over rights of pasturage, the herd dividing into two and engaging in a pitched battle for the possession of the disputed land. The Roebuck is smaller than the Fallow Deer, his height being about two 
feet six inches and his length three feet. He is less sociable than other species of his kind, living alone with his family and not in herds like the Fallow Deer. He is found in Scotland and in the northern parts of Europe.

The Giraffe. The Giraffe (Camelopardalis giraffa) belongs to Abyssinia, Nubia and South-Africa. It is the tallest of living animals, attaining to the height of eighteen feet. Its body has some similarity to that of the camel in form, and its head, which surmounts a neck seven feet long and bears two horns six inches long, resembles generally that of a horse. Its tongue, which can be extended seventeen inches, is very mobile and can be so tapered as to enter a small ring. It is used in tearing off the foliage of the trees upon which the animal feeds. Its neck, but for its length, is like that of the stag, and its legs are slender. The hide is spotted like that of the leopard and when young is of a light red colour, which becomes deeper with age, that of the female becoming a yellow brown and that of the male a dark brown approaching to black. In repose it lies on its side, resting its head on its hind quarters. Though only living in a wild state, the Giraffe is a mild and docile animal, only fighting in selfdefence, and then making powerful use of its heels. The lion is its great enemy and if it succeeds in leaping upon its back there is not much chance for the giraffe, which usually runs until it drops from exhaustion. A blow from the heel of the Giraffe in the right place would probably kill any of its enemies, and even the lion has been known to pay dearly for coming within its reach.

The History The Giraffe was known to the ancients, though, of the Girafie. like the gorilla, it has been re-discovered in recent years. Le Vaillant saw and described the giraffe, but he was credited with having invented it, and it was not until a live specimen of it was brought to Paris that his credibility was established. Mrs. Bowdich, who happened to be in Paris at the time this animal arrived, gives an amusing 
description of its triumphal march from Bordeaux to the Capital. "A deputation from each large town through which she passed," says Mrs. Bowdich, "formed of the municipal authorities, met her; and one of the most learned savants went all the way from the Jardin des Plantes, to accompany her on her march. 'La giraffe,' however, did not appreciate these honours, and was often impatient under the etiquette imposed on her. On one occasion she broke loose from her cavalcade, keeper and all, and dashing among the horsemen, scattered them right and left, some on and some off their steeds. A dignified mayor lay in the dust, and by his side rolled the painstaking savant who had performed so long a journey in her service. The enthusiasm did not abate when she reached her destination. Thirteen thousand more than the usual weekly number passed over the Pont d'Austerlitz alone; and as the public curiosity did not but increase for six weeks, steps were obliged to be taken to prevent the multitude from pressing upon her. Her love for roses was very great; and she eagerly snatched them from those who carried or wore them, to their great astonishment; for few could calculate on the distance which she could reach." Mr. Gordon Cumming describes a herd of ten giraffes which he saw moving together along an African valley, forming an imposing spectacle.

Hollow- We come now to a family of great importance Horned to the human race, the family which includes Ruminants. among its members the $\mathrm{Ox}$ and the Sheep. These are grouped as hollow-horned ruminants, this one touch of nature making the whole family kin. The hollowhorned ruminants are divided into numerous sub-families, of which the Ox, the Antelope, the Sheep, and the Goat are the best known representatives. The horn by which the family is characterised, comprises a hollow horny sheath which covers a bony core, and which, except in one case, unlike the horns of the stag, which are shed annually, is permanent Sir Victor Brooke divides the family of the Bovidæ into 

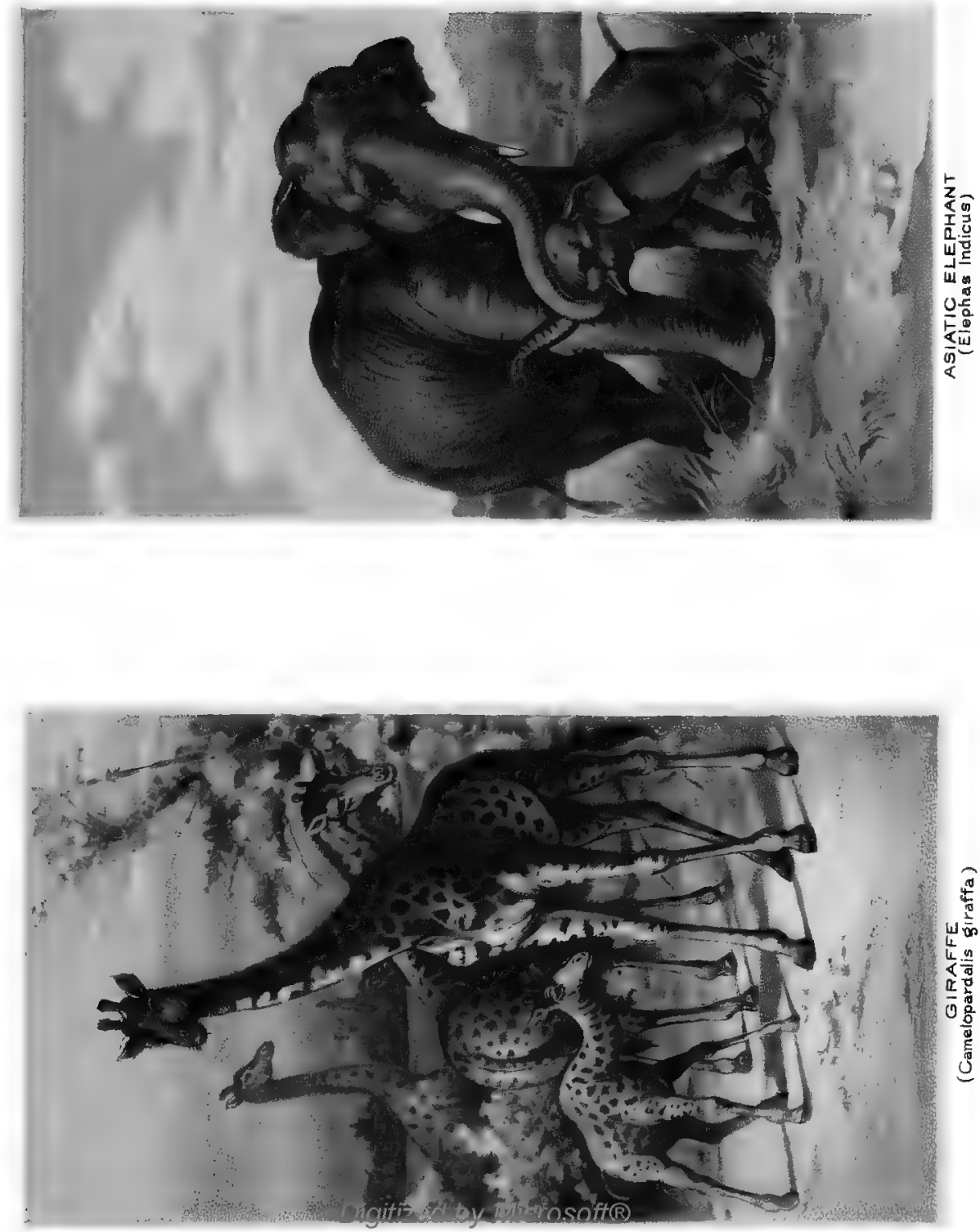
Digitized by Microsofte 
thirteen sub-families. I Bovinæ, II Tragelaphinæ, III Oryginæ, IV Hippotraginæ, V Gazellinæ, VI Antilocaprinæ, VII Cervicaprinæ, VIII Cephalophinæ, IX Alcephalinæ, X Budorcinæ, XI Rupicaprinæ, XII Nemorhedinæ, XIII Caprinæ.

The Bull, The sub-family Bovinæ includes the Bull, the The Bison, Bison, and the Buffalo. The antiquity of the The Buffalo. ruminants shrouds their origin in obscurity. They are of frequent mention in the sacred writings as belonging to the earliest historic period, and as living in a state of domestication in all times. The Bull has a very wide geographical area, and is found in most parts of the world. In England, as the Rev. J. G. Wood puts it, there are almost as many breeds as counties, and they are generally distinguished by the length or shape of their horns. The "longhorned " breed belong to Lancashire, the "short-horned" to Durham, the "middle-horned" to Devonshire, besides which there is the "polled", a hornless breed. Of the Bison there are two species, one belonging to Poland and the Caucasus, and the other to North America. The Buffalo belongs to the south of Europe, to India, and to North Africa, the Cape Buffalo inhabiting the south of "the dark continent."

The Bull. Few animals show as much difference of dis-

The Ox. position in the male and female as the Bull

The Cow. and the Cow. The Bull is often excited to ungovernable fury, is generally unsafe and often dangerous. These characteristics have doubtless marked him out as the object of sport in the Roman Amphitheatre and the Spanish Bull fight. The Cow, on the other hand, displays a gentle and docile disposition, is placid, mild, and obedient to the will of those who govern it. The Bull is kept mainly for the purposes of breeding, being too uncertain for use as a beast of burden or for other employment. The $\mathrm{Ox}$ which is the subdued offspring of the Bull and the Cow, is much more amenable to control and therefore a much more useful 
servant to man. The Cow is invaluable for the milk it supplies, upon which mankind is dependent for butter and for cheese.

The Bull. The Bull is a handsome animal and of great strength, especially about the head and neck. Its fierceness has often been turned to account by the farmer, for it is an excellent animal to dispute a right of way, the force of its arguments usually bearing down all opposition. It has been known also to use its strength for the protection of other animals. "Two robbers," says the author of "Domestic Animals and their Treatment," "took a pig, weighing fourteen stone, out of its sty, and drove it along, a lane leading towards Rotherham. On coming to a lonely path across the fields they thought it would be better to kill the pig at once in this quiet place, where no one would be likely to hear the cries of the animal. One of the robbers accordingly took a knife out of his pocket, and commenced cutting the pig's throat. The poor pig struggled violently, and managed to escape from his hands, running squealing into the next field, with a fearful gash in his throat. The men ran after the pig, but found in the field a bull grazing, who seemed at once to understand the state of the case, and took upon himself the championship of the wounded animal. The bull ran furiously at the robbers, who fled for their lives, and only just managed to escape a toss from his horns. They lingered outside the fence, however, hoping that an opportunity would still offer of their catching the pig; but the pig wisely kept close to his new friend, and the men at last were under the mortifying necessity of going home without their booty. These men were afterwards convicted of stealing sheep and corn, when one of them confessed this affair of the pig, and thus explained what had been a great mystery to the owner, namely, how it was that his pig came to be in a field at some distance from the sty, with his throat partly cut, and keeping close company with the bull." Mr. Byam's "Central America" 
affords another illustration: "A bull had gored so many cattle that he was lassoed, and his horns blunted at the tips to prevent further mischief. A few weeks after, a panther (jaguar) killed a cow; and from the torn condition of the bull's head and neck, and the trampled state of the ground, he had evidently done battle for the cow. He was secured, his wounds plastered up, his horns made sharp again, and turned out into the savannah. The wild dogs and vultures having been kept from the body of the cow during the day, the panther returned to his feast at night, and a furious engagement took place between him and the bull; for the former was found dead close by the cow the next morning, pierced through and through. The bull returned again and again to him with fury, and was himself again wounded; but his gashes were sown up, and he remained so fierce that his horns were obliged to be re-blunted."

The Brahmin The Brahmin Bull of India, is a sleek, tame

Bull. animal of a different species to the ordinary working ox. He is protected as sacred and allowed more liberty than is sometimes either convenient or pleasant, as he is apt to become obtrusive and his devotees fear to check or thwart him. Sacred as he is he does not believe in the eighth commandment and so helps himself without scruple to the wares of the fruiterer and the gardener's preserves.

The Ox. The $\mathrm{Ox}$ is one of the most useful creatures of the animal world. It is used as a beast of burden and employed to draw waggons and to drag the plough in England, and in a variety of useful labours abroad. "Every part of the $\mathrm{Ox}$ is of value," says the Rev. J. G. Wood. "We eat his flesh, we wear shoes soled with his skin, our candles are made from his fat, our tables are joined with glue made from his hoofs, his hair is mixed with the mortar of our walls, his horns are made into combs, knife-handles, drinking-cups, etc., etc., his bones are used as a cheap substitute for Ivory, and the fragments ground and scattered over the fields as manure, 
and soup is made from his tail." The value of the $O x$ in drawing waggons abroad may be gathered from the following quotation from Mr. Gordon Cumming's "Hunting Adventures in South Africa." "They (the oxen) are expected, unguided by reins, to hold the rare-trodden roads, which occur throughout the remoter parts of the Colony, either by day or night; and so well trained are these sagacious animals, that it is not uncommon to meet with a pair of fore-oxen which will, of their own accord, hold the "spoor" or track of a single waggon, which has perhaps crossed a plain six months previously."

The Cow. The Cow after supplying enormous quantities of milk during life is almost as valuable as the Ox when dead. It is from the Cow moreover that we get the lymph used in vaccination, which has proved such a wonderful safeguard against small-pox. In its quiet way the Cow sometimes shows sagacity. Mr. Bell gives us the following illustration:- "A cow which was feeding tranquilly in a pasture, the gate of which was open to the road, was much annoyed by a mischievous boy who amused himself by throwing stones at the peaceful animal, which, after bearing with his impertinence for some time, at length went up to him, hooked the end of her horn into his clothes, and lifting him from the ground, carried him out of the field and laid him down in the road. She then calmly returned to her pasture, leaving him quit with a severe fright and a torn garment." Cows have been taught to graze close to forbidden crops without yielding to the temptation to eat them.

The Pride A writer in Frank Leslie's popular monthly gives of a Cow. an amusing instance of vanity as shown by a cow. This cow, he was told, claimed precedence in all cases; she always went ahead of the herd and claimed the best piece of pasture as her exclusive domain. So far did she carry her pretensions, that if any of the other cows entered the stable before her, she would refuse to follow. Anxious to 
see this with his own eyes, he desired to be taken to her stable at evening. The man, instructed how to act, drove in some of the other cows. The white cow drew up; not only did she refuse to advance, in spite of all encouraging words, but her whole frame swelled with anger and offended dignity. She kept lowing continually. At last the cows within, as though conscious that they had forgotten their place, began to come out, and as they were driven out, the proud white cow, with an evident air of gratified pride, strode in in silence. It is almost impossible to convey the impression produced by this exhibition of downright pride, Hidalgo pride, in what many would call a dumb brute.

The Bison. The American Bison is a formidable animal when engaged alone, and when charging in a pack simply irresistible. $\mathrm{He}$ is about the size of an ox, one measured by Sir J. Richardson being eight feet six inches in length, without his tail, and more than six feet in height at his forequarters. He has an enormous head, surmounted by a huge hump on his shoulder which is covered in winter with shaggy mane-like hair. His hinder quarters are comparatively thin and small, and his colour is a dark brown approaching to black. Sharp piercing eyes and short powerful horns give him a fierce appearance and dangerous powers. He has enormous strength in his head and neck. The Bison is gregarious, associating in herds many hundreds strong. These herds have been greatly reduced during late years, but a herd seen by Captains Lewis and Clerk was numbered by them at not less than twenty thousand. "Such was the multitude of these animals, that, although the river, including an island over which they passed, was a mile in breadth, the herd stretched as thick as they could swim completely from one side to the other." When they join in a stampede, they are said to rush over the plains like a cataract, with a noise resembling that of thunder. Captain Brown says, "Bison generally prefer the open plains, and do not resort to woods, except when attacked; they seldom 
attempt to defend themselves, but almost invariably take to flight. They are extremely fleet, and their sense of smell is so acute, that they discover an enemy at a great distance, so that it is difficult to get near them. They are frequently hunted by the natives, who live principally on their flesh. When the hunters kill an old dam, they pay no attention to the calf, as it is sure to remain by its dead mother. Instances have been known of a mother entering the town of Cincinnati, followed by its calves. Many of them fall victims to wolves and grizzly bears. Their beef is of an excellent quality, and of a very superior flavour."

Eunting the Hunting the Bison is both a popular sport

Bison. and a lucrative commercial enterprise. The Indians hunt them for their skins, which they sell as "Buffalo robes," the Bison being commonly called a Buffalo by them, as well as for food. The Rev. J. G. Wood says, "The hunters take advantage of the gregarious instincts of this animal, and hunt them when they are collected together in their vast herds, which blacken the face of the prairie for miles. Sometimes they form in line, and drive the herd to the edge of some tall cliff, over which they fall in hundreds, those behind pushing on those in the van; or sometimes they form a large circle, driving the animals into a helpless and leaderless mass, into which the hunters spring, leaving their horses, and treading with the skill of rope-dancers on the backs of the bewildered bisons, whom they slaughter as they pass, stepping from one to the other, and driving the sharp blade of their spear through the spine of the animal whose back they have just quitted. When only wounded the Bison is a most dangerous antagonist, and rushes on its enemy with the most determined ferocity."

The Eastern Bison lives in the forests of Bialowesha in Lithuania under the protection of the Czar of Russia. The numbers are much smaller than those of North-America but they are said to be more fierce. 

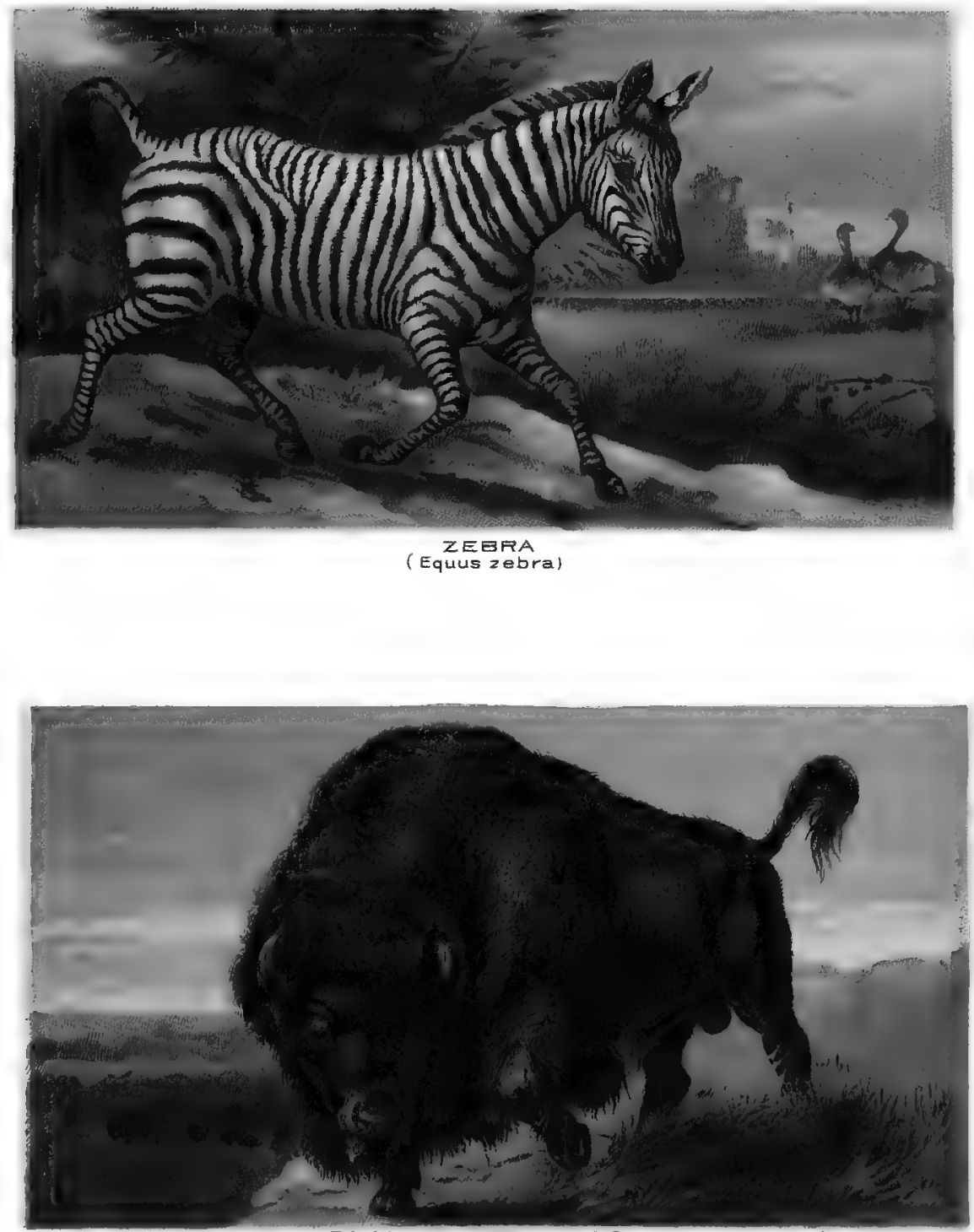
Digitized by Microsofte 
The Buffalo. The Buffalo, which must not be confused with the Bison, is similar in appearance to an ox, which it often exceeds in size. It has no hump on its shoulder as the Bison has, but it has much longer horns, horns that often measure three feet in length, and is much fiercer in their use. The Indian Buffalo will attack the hunter when it is brought to bay, and unless the hunter can despatch him as he approaches, there is no chance for him at close quarters. These Buffaloes, however, may be tamed and are often trained to and employed in useful service.

Hunting the Captain Brown gives the following account of Indian a Buffalo hunt which took place at Keshennagar,

Buffalo. in Hindostan, when four gentlemen on horseback chased a herd of seven buffaloes and a calf for a long distance. "After having followed them three miles, the young one separated from the herd, and joined some tame cattle belonging to a neighbouring village. It was killed by the party, who afterwards continued the pursuit of the old ones, when they were overtaken in a high grass jungle four miles farther off. They were quickly driven from this place, and closely followed for more than six miles over a plain: at length the party succeeded in separating one buffalo from the herd. Here the encounter began. After receiving several wounds, he still continued his flight; he suddenly halted, and kept his pursuers at bay; after a short interval he again fled, and was pursued and wounded as before, carrying the spears sticking in his back and sides for several hundred yards. Lieutenant White, of the I $5^{\text {th }}$ Native Infantry, rode up very close to him, threw his spear, and wounded the animal in the loins. His horse being much exhausted, was unable to wheel round before the buffalo turned about and charged with such vigour, that both horse and rider were overthrown, and lay many yards distant. Fortunately, the lieutenant received no material injury; and when the animal approached he had the presence of mind to lie flat on his back. The beast approached, but 
stood at his feet, without offering any violence. The othel sportsmen called repeatedly to their companion to arise and escape. For some time, however, he disregarded the advice, fearful of the consequences; at length, in compliance with their entreaty, he arose; the buffalo instantly rushed forward, but Mr. White escaped by throwing himself down; while the enraged beast, missing his aim, fell on the ground, his horns grazing Mr. White's back, as he passed over him. After this lucky escape, he seized the favourable opportunity, and regained his horse. The buffalo then took refuge in a tank; and when his former opponent joined his companions, who were standing upon the bank, the animal issued forth, and selecting Lieutenant White for the object of its vengeance, pursued him to a considerable distance. The animal was now rendered quite furious, and attacked everything within his reach, such as cows and dogs. Unfortunately, an old woman returning from market passed, and became the victim of his rage; she was taken up without any appearance of life, having her arms broken, and many wounds. The cavalry being, from fatigue, hors de combat, could not renew the attack; and the buffaloes, whose system was retreat, having gained a victory, now continued their course without molestation."

The Cape The Cape Buffalo is the fiercest of the Bull

Buffalo. family. He will charge a lion or a tiger and often come off victor in the strife. According to Mr. Pringle he is considerably larger than the domestic ox; the bony pad on his forehead making a complete helmet, and it is impossible to pierce him with bullets which have not been hardened by tin. $\mathrm{He}$ is said to be fierce, treacherous, and savage; and even when not provoked, to attack any man who strays near his haunts, skulking in the jungle when he sees him approach, and then suddenly rushing out upon him. Having tossed his enemy to his heart's content or thrown him down, he will trample and gore him, tearing off his skin with 
his tongue, until he is shockingly mutilated. $\mathrm{He}$ is one of the few animals which seem to cherish the spirit of revenge. Hunting the Mr. Pringle gives the following description of Cape Buffalo. a Cape Buffalo hunt. "A party of boers had gone out to hunt a herd of buffaloes which were grazing on a piece of marshy ground. As they could not get within shot of the game without crossing part of the marsh, which was not safe for the horses, they agreed to leave them in charge of the Hottentots, and advance on foot, thinking that if any of the buffaloes should turn upon them, it would be easy to escape by retreating across the quagmire, which, though passable for man, would not support the weight of a heavy quadruped. They advanced accordingly, and, under a covert of the bushes, approached the game with such advantage that the first volley brought down three of the fattest of the herd, and so severely wounded the great bull leader that he dropped on his knees, bellowing furiously. Thinking him mortally wounded, the foremost of the huntsmen issued from the covert, and began reloading his musket as he advanced to give him a finishing shot. But no sooner did the infuriated animal see his foe in front of him, than he sprang up and rushed headlong upon him. The man, throwing down his heavy gun, fled towards the quagmire; but the beast was so close upon him that he despaired of escaping in that direction, and turning suddenly round a clump of copsewood, began to climb an old mimosa tree which stood at one side of it. The raging beast, however, was too quick for him. Bounding forward with a roar which my informant described as being one of the most frightful sounds he ever heard, he caught the unfortunate man with his terrible horns just as he had nearly escaped his reach, and tossed him into the air with such force that the body fell, dreadfully mangled, into a cleft of the tree. The buffalo ran round the tree once or twice, apparently looking for the man, until, weakened. with loss of blood, he again sank on his knees. The rest 
of the party, recovering from their confusion, then came up and despatched him, though too late to save their comrade, whose body was hanging in the tree quite dead."

The Zebu. The Zebu is found in India, China, Arabia, Persia and Africa. It is of about the same size as a cow, but is distinguished by the possession of a hump upon its shoulders, giving it some resemblance to the Bison. It is used both for riding and driving in India, where it admirably serves the purposes of a horse, travelling at the rate of six miles an hour for many hours at a stretch and leaping obstacles with the facility of a practised hunter. It is also used for ploughing land and threshing corn.

The Yak. The Yak belongs to Western Thibet. It is of singular appearance, having the head of a bull and the hump of a Bison, and being covered with long hair reaching almost to the ground. In a wild state it is savage and dangerous, but it is brought under cultivation by the Tartars, who use it as a beast of burden and make ropes and garments from its hair. The female yields rich milk from which excellent butter is made; butter which is stored in bladders from which the air is excluded. It is then carried to market by the faithful animal which has produced it.

The Antelopes. The Antelopes are numerous in kind and various in form, too numerous and various to be separately described. The Eland, the largest and heaviest of the species, belongs to South Africa; the Bosch-bok, to South and Central Africa, the Harnessed Antelope to West Africa; and the Nylghau to India. The Leucoryx and the Addax are found in North Africa, the Equine Antelopes in tropical Africa and the Cape. The Pallah herds in South Africa. The Prong-horned Antelope belongs to North America, inhabiting the Rocky Mountains and the districts both north and south. The Bay Antelope is found on the Gold Coast, the Four-horned Antelope in India. The Gnu or Wildebeest belongs to South Africa and the Chamois and the Izard to the Pyrenees. 
The Gazelle. The Gazelle, of which there are numerous species, belongs to Syria, Egypt and Algeria. It is a beautiful animal, resembling a roebuck, but more delicately and finely limbed, with hair equally short, but finer and more glossy. It has a small tuft of hair on each of its fore limbs. Of all animals in the world, gazelles are said to have the most beautiful eyes-extremely brilliant, and yet meek and expressive. Their swiftness is equal to that of the roe; they do not, however, bound forward like the roe, but run along in an even uninterrupted course. Most of them are brown upon the back, white under the belly with a black stripe separating these colours. Their horns are annulated or ringed round.

The sheep The sheep, so useful to man, furnishing him and the Goat. with both food and clothing, is one of the most defenceless and inoffensive of all animals. The goat is more hardy, more playful, lively, and vagrant than the sheep. It delights in climbing precipices, for which nature has fitted it, by giving it hoofs hollow underneath, with sharp edges, so that it walks securely on narrow ridges. Both animals have been known from the earliest times, and are frequently mentioned in the Sacred Writings. Of the different kinds of sheep, the common sheep, the long-tailed sheep and the Wallachian sheep are typical varieties. The common sheep provides us with our chief supplies of wool. The wool of the Spanish sheep (the merino) is finer in quality, but much less in quantity. The long-tailed sheep belongs to Syria and Egypt, and the Wallachian sheep to Crete, Wallachia, Hungary, and Western Asia. This last has long horns, and its wool is mixed with hair. The musk sheep of Arctic America resembles the yak somewhat in appearance, though minus the hump and with horns more resembling those of the buffalo. It is sometimes called the musk ox. The goat is not much used in England, but it is practically the cow of Syria and Switzerland. The Cashmir goat produces the fine wool so much valued for shawl material; the kid, the materials so largely used by the 
glove makers. The ibex belongs to the Carpathians, the Pyrenees, and the Savoy Alps, though it is now but rarely found in places where it was once abundant.

The Intellig- Mr. W. H. G. Kingston tells an interesting ence of the story of a ewe, bred in the neighbourhood of

sheop. Edinburgh who was driven into Perthshire, a distance of upwards of a hundred miles, to a place where she became the mother of a lamb. Not liking her new quarters, she evidently determined to revisit the old, and set off with that purpose, taking her lamb with her. Arrived at Stirling she found the place alive with the excitement of an annual fair. Not deeming it prudent to increase the excitement she rested on the north side of the town throughout the day, where she was noticed by many people, but molested by none. Early the following morning she crossed the town and proceeded on her journey. Arrived at the toll bar of St. Ninians, she was stopped by the toll keeper who supposed her to be a stray sheep. Unable to get through the gate, she turned back, made a circuitous detour and reached her old home after a journey of nine days. Her former owner rewarded her by repurchasing her and allowing her to remain on his farm until her death, which occurred at the mature age of seventeen years. The sense of locality noticed in the cat, the dog, the horse, and other animals is here seen to be characteristic of the sheep: Mr. Kingston tells another story of a ewe who, unable to extricate a lamb which had become entangled in a hedge, made her way through several hedges into a neighbouring field and fetched a ram to its assistance, thus effecting its liberation. Sheep have also been known to seek and secure the assistance of cattle when in difficulty.

sheep and Haydn the composer tells a pretty story of the Music. power of music over the mountain sheep in the neighbourhood of Lago Maggiore in Lombardy. "Having reached the middle of the ascent by daybreak," he says, "we stopped to contemplate the Borromean Isles, which were 
displayed under our feet, when we were surrounded by a flock of sheep, which were leaving their fold to go to pasture. One of our party, who was no bad performer on the flute, and who always carried the instrument with him, took it out of his pocket. 'I am going,' said he, 'to turn Corydon; let us see whether Virgil's sheep will recognise their pastor.' He began to play. The sheep and goats, which were following one another towards the mountain with their heads hanging down, raised them at the first sound of the flute, and all, with a general and hasty movement, turned to the side from whence the agreeable noise proceeded. They gradually flocked round the musician, and listened with motionless attention. He ceased playing, and the sheep did not stir. The shepherd with his staff now obliged them to move on; but no sooner did the fluter begin again than his innocent auditors again returned to him. The shepherd, out of patience, pelted them with clods of earth; but not one of them would move. The fluter played with additional skill; the shepherd fell into a passion, whistled, scolded, and pelted the poor creatures with stones. Such as were hit by them began to march, but the others still refused to stir. At last the shepherd was forced to entreat our Orpheus to stop his magic sounds; the sheep then moved off, but continued to stop at a distance as often as our friend resumed the agreeable instrument. As music was our continual employment, we were delighted with our adventure; we reasoned upon it the whole day, and concluded that physical pleasure is the basis of all interest in music."

ORDER VIII. Of the elephant there is now but one genus The Elephant. and two species; respectively the Indian and the African varieties. At least fourteen species are known to be extinct.

The elephant is the largest of the quadrupeds; his height is from eight to fourteen feet; his length is ten to fifteen feet. His form resembles that of a hog; his eyes are small 
and lively; his ears are broad, long, and pendulous. He has two large tusks, and a trunk or proboscis at the extremity of the nose, which he uses to take his food with, and, in case of necessity, for attack or defence. His legs are thick and long, and his feet are divided into five rounded toes. His colour is a dark ash brown. There are elephants, however, of a white or cream colour. The African is distinguished from the Indian variety by the size of its ears, which in the African species are very large. Dr. Livingstone gave the measurement of the ears of a fernale he killed, as four feet five inches in depth and four feet in horizontal breadth, and said he had seen a native creep under one so as to be completely covered from the rain. The ear of the Indian variety is not more than a third of this size. Generally the elephants of Africa and especially those of the south are larger than those of India. The most striking characteristic of the elephant is his trunk. "In this," says the Rev. J. G. Wood, "there are about forty thousand muscles, enabling the elephant to shorten, lengthen, coil up, or move in any direction this most extraordinary organ. The trunk is pierced throughout its length by two canals, through which liquids can be drawn by suction. If the elephant wishes to drink, after drawing the liquid into its trunk, it inserts the end of its proboscis into its mouth, and discharges the contents down its throat; but if it merely wishes to wash itself or play, it blows the contained liquid from the trunk with great violence. Through the trunk the curious trumpetlike voice of the elephant is produced. At the extremity is a finger-like appendage, with which it can pick up small objects." The elephant is thirty years old before he attains maturity. He lives on foliage, herbs, and fruits, having a special taste for those which are sweet.

The wild The elephant is naturally a quiet and inoffensive

Flephant. animal, and being gifted with an unusually keen scent and sense of hearing, will usually decamp on the approach 
of danger. If wounded, however, he will sometimes turn upon his aggressor with terrible vengeance. Mr. Burchell, the South African traveller, gives a painful illustration of this. He says:"Carl Krieger was a fearless hunter, and being an excellent marksman, often ventured into the most dangerous situations. One day having, with his party, pursued an elephant which he had wounded, the irritated animal suddenly turned round, and singling out from the rest the person by whom he had been injured, seized him with his trunk, and lifting his wretched victim high in the air, dashed him with dreadful force to the ground. His companions, struck with horror, fled precipitately from the fatal scene, unable to look back upon the rest of the dreadful tragedy; but on the following day they repaired to the spot, where they collected the few bones that could be found, and buried them. The enraged animal had not only literally trampled Krieger's body to pieces, but did not feel its vengeance satisfied till it had pounded the very flesh and bones into the dust, so that nothing of the unfortunate man remained excepting a few of the latter, which made most resistance from their size." Another elephant seized a soldier of the Royal African Corps, threw him down, brought his four feet together and stamped upon him until he was dead; then seizing the body with his trunk, threw it into the jungle.

Fllephant Major Skinner in a communication made to Herds. Sir E. Tennant gives the following graphic description of the actions of a herd of elephants he watched on one occasion in the north of Ceylon. Knowing that from the scarcety of water at that time and place a large herd of elephants which he knew to be in the neighbourhood must visit a certain pool during the night he made his preparations accordingly. He says:- "Having ordered the fires of my camp to be extinguished at an early hour, and all my followers to retire to rest, I took up my post of observation on an overhanging bough; but I had to remain for upwards of 
two hours before anything was to be seen or heard of the elephants, although I knew they were within 500 yards of me. At length, about the distance of 300 yards from the water, an unusually large elephant issued from the dense cover, and advanced cautiously across the open ground to within IOO yards of the tank, where he stood perfectly motionless. So quiet had the elephants become (although they had been roaring and breaking the jungle throughout the day and evening) that not a movement was now to be heard. The huge vidette remained in his position, still as a rock, for a few minutes, and then made three successive stealthy advances of several yards (halting for some minutes between each, with ears bent forward to catch the slightest sound), and in this way he moved slowly up to the water's edge. Still he did not venture to quench his thirst; for though his forefeet were partially in the tank, and his vast body was reflected clear in the water, he remained for some minutes listening in perfect stillness. Not a motion could be perceived in himself or his shadow. He returned cautiously and slowly to the position he had at first taken up on emerging from the forest. Here in a little while he was joined by five others, with which he again proceeded as cautiously but less slowly than before, to within a few yards of the tank, and then posted his patrols. He then re-entered the forest and collected around him the whole herd, which must have amounted to between eighty and a hundred individuals, led them across the open ground with the most extraordinary composure and quietness till he joined the advance guard, when he left them for a moment and repeated his former reconnaissance at the edge of the tank. After which and having apparently satisfied himself that all was safe, he returned and obviously gave the order to advance, for in a moment the whole herd rushed into the water with a degree of unreserved confidence, so opposite to the caution and timidity which had marked their previous movements, that nothing will ever persuade me that there was 
not rational and preconcerted co-operation throughout the whole party, and a degree of responsible authority exercised by the patriarch leader.

"When the poor animals had gained possession of the tank (the leader being the last to enter), they seemed to abandon themselves to enjoyment without restraint or apprehension of danger. Such a mass of animal life I had never before seen huddled together in so narrow a space. It seemed to me as if they would have nearly drunk the tank dry. I watched them with great interest until they had satisfied themselves as well in bathing as in drinking, when I tried how small a noise would apprise them of the proximity of unwelcome neighbours. I had but to break a little twig, and the solid mass instantly took flight like a herd of frightened deer, each of the smaller calves being apparently shouldered and carried along between two of the older ones. In drinking, the elephant, like the camel, although preferring water pure, shows no decided aversion to it when discoloured with mud; and the eagerness with which he precipitates himself into the tanks and streams attests his exquisite enjoyment of the fresh coolness, which to him is the chief attraction. In crossing deep rivers, although his rotundity and buoyancy enable him to swim with a less immersion than other quadrupeds, he generally prefers to sink till no part of his huge body is visible except the lip of his trunk through which he breathes, moving beneath the surface, and only now and then raising his head to look that he is keeping the proper direction."

Elephant The affection shown by elephants for each Friendships. other has often had pathetic illustration. Two elephants, male and female, which had been brought separately to Paris, were placed in adjoining apartments divided by a portcullis. The male soon discovered that this was fastened by a bolt well within his reach, and hastily withdrawing it rushed into the other apartment. The meeting is described as in- 
describable. Their cries of joy, says Mrs. Bowdich, shook the whole building, and they blew air from their trunks resembling the blasts from smiths' bellows. The female moved her ears with great rapidity, and entwined her trunk round the body of the male. The male encircled her with his trunk and shed tears.

The

The sagacity of the elephant has been said Elephant's sometimes to equal that of the dog. A striking

sagacity. illustration of it is related in Pettit's work on the Tinnevelly Missions. "While the large chapel at Nagercoil was building the missionaries obtained the loan of a trained elephant for drawing the larger timber used in its erection. The late Mrs. Mault kindly saw the animal regularly fed, lest the food should be stolen by the attendant. One day the allowance of rice seemed very deficient in quantity, and the good lady expostulated on the subject with the keeper. Raising his hands to heaven, the man loudly, and with great apparent earnestness and sincerity, repudiated the idea of his having taken any of the rice. 'Do you think, madam, that I would rob my child? No, never! no more than I would deprive my own children of their daily food.' While he was speaking and gesticulating, the intelligent creature, slyly extending his trunk, unfastened the man's waist-cloth, spilling the missing rice, which had been concealed in a corner of the cloth, and exposing the dishonesty of the attendant."

A. Some years ago there was an elephant who was Oentenarian known to be a hundred years old, named SoupElophant. ramany, or Old Soup as he was called, who lived upon the banks of the Ganges near the city of Cawnpore. On one occasion Old Soup was engaged with a number of other elephants and a party of soldiers, under the direction of Major Daly, in loading a ship with bags of rice. While the work was proceeding one of the elephants began to throw the bags into the river, and it was found that the animal had gone mad. Having killed his keeper the elephant 
started in pursuit of the major's children who with their nurses had been watching the elephants at work. Old Soup seemed to realize the situation at once. He dashed in between the mad elephant and the children and engaged the infuriated beast in mortal combat. The fight lasted for an hour and a half and when the mad elephant lay dying on the ground it was found that Old Soup had many wounds to remind him of the fray, his ears were badly torn, his head was bruised, and one of his tusks was broken off short. An Elophant Elephants are most affectionate animals and Trurse. can be trusted even to take care of children. Old Soup whose gallant fight recorded above gained him great fame, became the daily guardian of Major Daly's children, whom he had so heroically rescued. He would accompany them down to the riverside when they went fishing, and could himself hold a rod and line, which the children baited for him, watching the float and landing the fish as skilfully as an accomplished angler.

The

As we have seen in the case of a dog and Flephant's that of a monkey, animals sometimes rise to Intelligence. the intelligence of willingly submitting to painful surgical treatment in view of cure. Mr. Kingston tells of an elephant, which had been severely wounded, and which used to go alone to the hospital and extend itself so that the surgeon could easily reach the injured part. Mr. Kingston says: "Though the pain the animal suffered, was so severe that he often uttered the most plaintive groans, he never interrupted the operation, but exhibited every token of submission to the surgeon till his cure was effected." Another instance given by $\mathrm{Mr}$. Kingston is even more remarkable if only for its analogy to human conduct. A young elephant had a severe wound in its head, which it had gained on the battle-field. "Nothing could induce it to allow the injury to be attended to. At length by certain signs and words, the keeper explained to the mother what was wanted. 
The sagacious animal immediately seized the young one with her trunk, and though it groaned with agony, held it to the ground, while the surgeon was thus enabled to dress the wound. Day after day she continued to act in the same way till the wound was perfectly healed." There is surely no stronger proof of intelligence than that afforded when present suffering is willingly endured for the sake of future good.

ORDER IX. The Coney is a small animal, but it is an

The Coney. animal of distinction. It has been classed with the Rodents and with the Pachyderms but its characteristics are so unique that it is thought better to give it a separate order, and this is placed between the Elephants and the Rodents. The coney resembles the rabbit in size and general form, perhaps more than any other animal. There are a number of species belonging to one genus, the genus Hyrax: In Psalm crv, 18, the writer says the rocks are a refuge for the conies, and Agur puts the coney with three other animals which are both little and wise. "The conies are but a feeble folk, yet they make their houses in the rocks (Proverbs xxx, 26). This description applies to the Syrian Hyrax of our day as truly as it did to that of the Psalmists time. The coney is found all over Africa. According to Dr. Kirk it lives in colonies at Mozambique, where it is often trapped and eaten.

ORDER X. The Rodents are more numerous and various The Rodents: than any other class of mammals: There are Animals said to be 800 or more varieties. These are that Gnaw. divided into two sub-orders: I, The Simplicidentati and, II, the Duplicidentati. Those of the first suborder have two incisor teeth in the upper jaw; those of the second have four. The Simplicidentati include mice, rats, jerboas, beavers, squirrels, chinchillas, porcupines, guinea pigs, \&c.; the Duplicidentati includes the numerous varieties of hares and rabbits. 
Rats and There are more than 300 varieties of rats and Mice. mice, and they are found almost everywhere. The rat is an irrepressible stowaway, and following toothsome cargoes on board ship has made his way nearly all over the world. This may be said, in a less degree, of the mouse. The better known varieties of rats are the Brown Rat, the Black Rat, the Water Rat, the Beaver Rat, the Musk Rat, the Lemming, the Pouched Rat, \&c., \&c. The principal varieties of the mouse are, the House Mouse, the Fieldmouse, the Harvest Mouse, the African Mouse and the Dormouse.

The Rat The brown rat is the species common in Famlly. England, and best known throughout the world. It is said to have travelled from Persia to England less than two hundred years ago and to have spread from thence to other countries visited by English ships. It measures about nine inches, and is of a light brown colour. It multiplies very fast and once colonised is very difficult of extermination. It is larger and stronger than the black rat which it found in England when it came and which it has almost entirely destroyed and replaced. The brown rat is often mistaken for the water rat as it will take to the water on occasion and is often found in ditches and watery places. The water rat is common to central and northern Europe and is well known in England and Scotland. It differs little from the brown rat in appearance, and inhabits the banks of rivers and ponds. The black rat is of a deep iron grey, or nearly black. It is about seven inches long and in other respects bears a close resemblance to the brown rat. The beaver rat is a native of America and measures about fourteen inches exclusive of tail. It resembles the beaver in form, is fond of the water and swims well. At the approach of winter it builds itself little dome-topped houses, in which it hibernates in families. In the spring its flesh is good eating, but later it acquires a musk-like flavour which is disagreeable. It is easily tamed when young. The Muskovy musk rat is about 
the size of the common rat; it has a long and slender nose; no external ears; and very small eyes; the tail is compressed sideways, and its hind feet are webbed; it is of a dusky colour; the belly is of a light ash. It is a native of Lapland and Russia, in the former of which countries it is called the Desman; it frequents the banks of rivers, and feeds on small fish. The Hudson's Bay lemming is covered by very fine soft and long hair of an ash colour. In winter it is white. The limbs are quite short and the fore feet being formed for burrowing, are very strong. The Lapland lemming resembles the preceding and is remarkable for its extensive migrations. When a severe winter is approaching, the lemmings migrate southward, and move in a straightforward direction with such inflexible regularity, that, sooner than deviate from it, they will perish in attempting to pass over any obstacle which they may find in their way. The pouched rat belongs to America and is found in Florida, Georgia, and Missouri. It is brown in colour and lives in burrows under ground. The cheek pouches are external and are said to be used for the purpose of carrying food and also of removing sand loosened in the process of burrowing.

The The hamster is a curious little rat-like animal

Famster. of the thrifty kind, that lays up store in the summer for winter use. It lives in burrows which it connects with various apartments, used as storehouses for food. On the approach of the cold weather it closes the entrance to its burrow, and makes a nest of straw in which it sleeps, becoming torpid in extreme cold.

swarms of The rapidity with which rats multiply, makes

Rats. them troublesome and unpleasant neighbours. In the vicinity of the horse slaughter-houses at Montfaucon, near Paris, some years ago, they had become so numerous that the proposal to remove the slaughter houses was opposed on the ground of the danger that would accrue to the inhabitants from the rats being deprived of their means 
of subsistence. It was said that the carcases of thirty-five horses, if left unprotected, would be eaten by these rats in one night, the bones being picked clean. On one occasion, the carcases of three horses were placed in a high walled enclosure, small holes having been made in the walls for the admission of the rats, and subsequently stopped up. Several men armed with torches and sticks, then entered the yard, which was so full of rats that they could strike right and left without aim and yet be sure of destroying them. Two thousand six hundred and fifty rats fell victims to this experiment in one night. At the end of a month, the experiment having been several times repeated, sixteen thousand and fifty rats had been killed. The danger accruing from the burrowing of such enormous quantities of rats is by no means slight.

Invaded by The story of Bishop Hatto and the invasion Rats. of the "Mäusethurm" on the Rhine by rats, is well known if not entirely authentic. Some idea of what it would be to be invaded by rats, may be gathered from Mrs. Bowdich's graphic account of her own painful experiences. "When living in Cape Coast Castle, I used to see the rats come in troops past my door, walking over my black boys as they lay there, and who only turned themselves over to present the other sides of their faces and bodies when the rats returned, and thought it a good joke. The fiercest encounter which I ever had with them was during one of those terrific storms which are more furious between the tropics than elsewhere. I was then, however, under the Equator, in a native hut, and heard an exceeding rustling and movement all around me. To my terror I perceived that these proceeded from a number of rats running up and down the sides of the room in which I was to pass the night, and who shortly began to run over me, they being disturbed by the torrents of rain which were then falling. The only weapon I could find was a shoe, and curling myself into a 
large arm-chair taken out of a French vessel, and covered with blue satin damask, I sat prepared for my enemies, whom I dreaded much more than the lightning, which was flashing across the iron bars laid upon the floor. I felt that the silk of my place of refuge was some sort of protection against this; but my own arm could alone save me from my fourfooted foes. Presently my husband came in, and saluted me with a shout of laughter, which, however, abated when he saw my antagonists. The storm lulled for a while, and the rats retreated. We then crept within the curtains of bamboo cloth which encircled a rude imitation of a fourpost bedstead, but I kept possession of my shoe. Weary with watching, I closed my eyes, but was awakened by a tremendous flash of lightning, immediately followed by awful thunder and a tumultuous rush of rats. Some of them scrambled up the outside of the curtains; but, arms in hand, I sat up, and directed by the noise, I hurled the invaders to the ground, till at length resistance and the passing away of the storm allowed me to sleep in peace." This was the brown rat so familiar all over the world.

Migrations The habit of rats to migrate in numbers, apof Rats. parently well ordered, and under leadership, has often been noticed, and the way in which they will leave a burning house or a sinking ship has often been recorded. These companies will as a rule pass on their own way, and mind their own business if unmolested, but instances are recorded of their attacking and severely biting those who have opposed their progress. The Rev. Mr. Ferryman, who resided at Quorn in Leicestershire and who made somewhat of a study of rats, was walking in a meadow one evening when he observed a large number of rats in the act of migrating from one place to another. He stood perfectly still, and the whole assemblage passed close to him. His astonishment, however, was great when he saw amongst the number an old, blind rat, which held one end of a piece of stick in its mouth while 
another rat had hold of the other end of it, and thus conducted its blind companion.

The

Some remarkable illustrations of the intelligence Intelligence of rats have been recorded from time to time. of Rats. The following which occurred recently seems to show both thought and reason. A Burley rat found a dead hen in a field, one evening, and departed to inform his brethren of the discovery, when a gentleman, who afterwards reported the incident to the Leeds Evening Post-removed the prize, which the speedy return of half-a-dozen rats was too late to secure. The first rat plainly evinced his disappointment, but his friends suspected him of hoaxing them, turned upon him suddenly, and in a few moments he was as dead as the chicken which had disappeared, and was left lying on almost the same spot which it had occupied. Captain Brown tells the following story of the ingenuity of the rat in self-preservation. "During the great flood of September, the $4^{\text {th }}$, I829, when the river Tyne was at its height, a number of people were assembled on its margin. A swan at last appeared, having a black spot on its plumage, which the spectators were surprised to find, on a nearer approach, was a live rat. It is probable it had been borne from its domicile on some hay rick, and, observing the swan, had made for it as an ark of safety. When the swan reached the land, the rat leapt from its back, and scampered away.

gaved by a Perhaps no better example of the intelligence Rat. of the rat could be given than that afforded by the incident quoted by Jesse from Mr. Ferryman. Mr. Ferryman records that he had an old friend, a clergyman, of retired and studious habits. When sitting in his room one day, he saw an English rat come out of a hole at the bottom of the wainscot; and threw it a piece of bread. In process of time, he so familiarised the animal, that it became perfectly tame, ran about him, was his constant companion, and appeared much attached to him. He was in the habit of 
reading in bed at night; and was on one occasion awoke by feeling a sharp bite on his cheek, when he discovered the curtains of his bed to be on fire. He made his escape, but his house was burnt down, and he saw no more of his rat. He was, however, convinced, and remained so for the rest of his life, that his old companion had saved him from being burnt to death, by biting his cheek; and thus making him aware of his danger.

The Mouse. The mouse is a much more popular animal than the rat, though taking its size and numbers into account it is scarcely less destructive. No one weeps when the rat suffers capital punishment, but many a tear has been shed over a "dear little mouse". The house mouse is too well known to need description. Like rats, mice appear to act in companies, either under leadership or by common consent. Mrs. Bowdich describes a number of mice which she observed during an illness frequently emerge from her bed-room closet and gravely form themselves into a circle and apparently hold a council. That they frequently combine to effect purposes which they are unable to accomplish singly is well known. Mrs. Bowdich describes an attempt made by a combined force of mice to get possession of the dainties provided for her as she approached convalescence. These were placed under tin covers upon a chest of drawers, and the mice were evidently of opinion that if they could only climb to the top of these covers they would find them open like a basin, and so effect an entry. Unable to gain a footing on the smooth metal sides, "they mounted upon each other's shoulders and so accomplished the feat", though like arctic explorers they failed to find an open sea and were compelled to return with disappointment. An organised attempt to remove a cover from the bottom, when, on one occasion, it had not been firmly set down, resulted in an accident similar to those incident to human engineering, for the cover slipped and many tiny hands were severely pinched, After this 
they abandoned their attempts though a single mouse would occasionally reconnoitre the scene, apparently unsatisfied with the defeat. Mice, like many other animals, are said to be much affected by music.

The

The harvest mouse is a most interesting little

Harvest creature; whose habits are thus described by

Mouse. White of Selborne:- "They build their nest amidst the straws of the corn above the ground, and sometimes in thistles. They breed as many as eight at a litter, in a little round nest composed of the blades of grass or wheat. One of these I procured this autumn, most artificially plaited, and composed of the blades of wheat, perfectly round, and about the size of a cricket ball, with the aperture so ingeniously closed that there is no discovering to what part it belonged. It was so compact and well filled that it would roll across the table without being discomposed, though it contained eight little mice that were naked and blind. As this nest was perfectly full, how could the dam come at her litter. respectively so as to administer a teat to each? Perhaps she opens different places for that purpose, adjusting them again when the business is over; but she could not possibly be contained, herself, in the ball with her young, which moreover would be daily increasing in bulk. This procreant cradle-an elegant instance of the efforts of instinct - was found in a wheat field, suspended in the head of a thistle."

'The Field There are two kinds of field mice, the long-

Mouse. tailed and the short-tailed varieties. The longtailed field mouse is the mouse immortalised by Burns, and is found throughout Europe. The short-tailed variety occupies much the same geographical area, though it probably extends further. The latter are very destructive, and have sometimes increased to such an extent, that organised efforts have had to be made to exterminate it.

The The common dormouse, and the greater dorDormouse. mouse are the principal varieties of this interestin 
little animal. They resemble the squirrel in appearance as well as in some of their habits. They live in trees, where they construct nests, on nuts, acorns, fruits, insects, birds and eggs, and squirrel-like rest upon their hindquarters when eating, holding their food between their forepaws. They lay up store for the winter and become torpid in the cold weather, rolling themselves into a ball, in which condition they may be handled without disturbance or injury. The common dormouse is found all over Europe, the greater dormouse occupying a still more extended area.

The Jerboa. The Jerboa is a curious little animal with the body of a mouse and hind legs which resemble those of the kangaroo in appearance. There are several varieties, one belonging to Southern Russia, one to the deserts of Egypt, Nubia, Arabia, Barbary and Tartary, and one to North America. They live in burrows which they construct with great care and industry. They are naturally timid and make for their holes on the slightest disturbance, leaping kangaroo fashion sometimes as high as five feet, and so swiftly as to be very difficult of capture. They have very long tails.

The Beaver. There are two species of the beaver, the European beaver, and the American beaver. The former is most numerous in Siberia, Tartary, and the Caucasus but is also occasionally found in Central Europe. The American beaver is found throughout North America where it is eagerly hunted for the sake of its fur.

The European The following anonymous paragraph cut from

Beaver. a newspaper, but likely enough quoted from some standard Natural History, perhaps that of Messrs. Cassell and Co., throws some light upon the present condition of the European beaver.

"There are still some naturalists who assert that the beaver has ceased to exist in France. This, however, is a mistake; an animal of that species was caught a short time ago in the Hérault, and is now being exhibited at Montpelier. Beavers 
do not live in Europe in large companies or herds as they do in America, but only in solitude, and in this state they haunt secondary rivers, such as the Gard and the Gardon. There are a few on the banks and islands of the Rhone, but as these creatures are averse to noise, the splashing of the steamers plying to and fro has driven most of them away. They give a decided preference to such streams as are overshadowed by the willow, of the bark of which they are exceedingly fond. The beaver is also to be found as far north as the Saone, in those valleys where there is peat-ground. It lives in Spain, in Italy, and in Greece, but always solitary and fugitive. This curious animal is not only called Castor Americanus, but also Castor Gallicus, and not without reason, since the fossil remains of the genus are sufficient to attest their having been very numerous in France at some remote period. The little stream of the Bièvre derives its name from its having been the habitat of these creatures; its resemblance to the English name beaver need hardly be alluded to. In Europe this amphibious animal does not build those substantial and commodious dwellings which have rendered it so celebrated, because the rapacity and spirit of destruction so common in man have made it suspicious and cautious."

The American Writing of the American Beaver Dr. Godman

Beaver. says :- "Beavers are not particular in the site they select for the establishment of their dwellings, but if in a lake or pond, where a dam is not required, they are careful to build where the water is sufficiently deep. In standing waters, however, they have not the advantage afforded by a current for the transportation of their supplies of wood, which, when they build on a running stream, is always cut higher up than the place of their residence, and floated down. The materials used for the construction of their dams are the trunks and branches of small birch, mulberry, willow, and poplar trees. They begin to cut down their timber for build- 
ing early in the summer, but their edifices are not commenced until about the middle or latter part of August, and are not completed until the beginning of the cold season. The strength of their teeth, and their perseverance in this work, may be fairly estimated by the size of the trees they cut down. Dr. Best informs us, that he has seen a mulberry tree, eight inches in diameter, which had been gnawed down by the beaver. The figure of the dam varies according to circumstances. Should the current be very gentle, the dam is carried nearly straight across; but when the stream is swiftly flowing, it is uniformly made with a considerable curve, having the convex part opposed to the current. Along with the trunks and branches of trees they intermingle mud and stones, to give greater security; and when dams have been long undisturbed and frequently repaired, they acquire great solidity, and their power of resisting the pressure of water and ice is greatly increased by the trees occasionally taking root, and eventually growing up into something of a regular hedge.

"The dwellings of the beaver are formed of the same materials as their dams, and are very rude, though strong, and adapted in size to the number of their inhabitants. These are seldom more than four old and six or eight young ones. Double that number have been occasionally found in one of the lodges, though this is by no means a very common circumstance. When building their houses, they place most of the wood crosswise, and nearly horizontally, observing no other order than that of leaving a cavity in the middle. Branches which project inward are cut off with their teeth, and thrown among the rest. The houses are by no means built of sticks first and then plastered, but all the materials, sticks, mud, and stones, if the latter can be procured, are mixed up together, and this composition is employed from the foundation to the summit. The mud is obtained from the adjacent banks or bottom of the stream or pond near the 
door of the hut. Mud and stones the beaver always carries by holding them between his fore paws and throat.

"Their work is all performed at night, and with much expedition. As soon as any part of the material is placed where it is intended to remain, they turn round and give it a smart blow with the tail. The same sort of blow is struck by them upon the surface of the water when they are in the act of diving. The outside of the hut is covered or plastered with mud late in the autumn, and after frost has begun to appear. By freezing it soon becomes almost as hard as stone, and effectually excludes their great enemy, the wolverine, during the winter."

The squirrel. The family of the Squirrel is a very large one and with it are included the marmots, the prairie dogs, and the anomalures, the latter of which form a sub-family. The common squirrel, the variety familiar in England, is a pretty little creature with its bright piercing eyes, and knowing look, and its graceful bushy tail. It is one of the most agile of animals, ascending and descending trees with the rapidity of a flash and so sensitive, that it is said that if the tree upon which its nests is only touched at the bottom it takes alarm and seeks safety on another tree. It builds its nests in the forks of branches of trees,-of moss, twigs, and dried leaves, -and leaps great distances from tree to tree. The ground squirrel is characterised by fine longitudinal black bands on its back, which form a very pretty marking. It belongs chiefly to North America. "It lives in villages under ground," says an American writer, "and plunders the farmers worse than the gopher. Every two months the ground squirrel breeds and neither State premiums nor strychnine diminishes its numbers. It levies an assessment of thirty per cent. on the profits of a wheat crop in many sections."

The flying squirrel, also common in the United States, has a membranous skin which extends from the fore limbs along the body to the hind limbs by which its body is buoyed up 
as it descends obliquely through the air from the tree to the ground, the tail operating as a rudder. One species of the flying squirrel is found in Europe and several in India.

The squirrel Mr. Head gives a graphic description of his expe-

at Home. riences with a squirrel in the Canadian woods. He says:-_ I was waiting the approach of a large flock of wild fowl, but a little villain of a squirrel on the bough of a tree close to me, seemed to have determined that even now I should not rest in quiet, for he sputtered and chattered with so much vehemence, that he attracted the attention of my dog, whom I could scarcely control. The vagrant inattention of my dog was truly mortifying; he kept his eyes fixed upon the squirrel, now so noisy as to be quite intolerable. With my hand, I made a motion to threaten him, but the little beast actually set up his back, and defied me, becoming even more passionate and noisy than before, till all of a sudden, as if absolutely on purpose to alarm the game, down he let himself drop, plump at once within a couple of yards of Rover's nose. This was too much for any four-footed animal to bear, so he gave a bounce and sprang at the impertinent squirrel, who, in one second, was safe out of his reach, cocking his tail, and showing his teeth on the identical bough where he had sat before. Away flew all the wild fowl, and my sport was completely marred. My gun went involuntarily to my shoulder to shoot the squirrel. At the same moment, I felt I was about to commit an act of sheer revenge, on a little courageous animal which deserved a better fate. As if aware of my hesitation, he nodded his head with rage, and stamped his fore paws on the tree: while in his chirruping, there was an intonation of sound, which seemed addressed to an enemy for whom he had an utter contempt. What business, I could fancy he said, had I there, trespassing on his domain, and frightening his wife and little family, for whom he was ready to lay down his life? There he would 
sit in spite of me, and make my ears ring with the sound of his war whoop, till the spring of life should cease to bubble in his little heart."

Tamo Captain Brown tells of a gentleman who had a

Bquirrels. tame squirrel, who used to run up his legs and enter his pocket when he saw him preparing to go out. From this safe retreat the squirrel often poked his head and peeped at the people as they passed, but never ventured to emerge until the crowded thoroughfares were passed. When they reached the outskirts of the city, however, the squirrel leaped to the ground, ran along the road, ascended trees and hedges, with the quickness of lightning, and nibbled at the leaves and bark. If the gentleman walked on, it would descend, scamper after him, and again enter his pocket. On hearing a carriage or cart, it became much alarmed, and always hid itself till it had passed by. This gentleman had a dog, between which and the squirrel a certain enmity existed. Whenever the dog lay asleep, the squirrel would show its teasing disposition, by rapidly descending from its box, scampering over the dog's body, and quickly mounting to its box again. Another squirrel who frequented his master's pocket, on one occasion rendered important service. One evening, as was his practice, when his master's coat was taken off and hung behind a door, the squirrel ran up the door and took up his quarters in the familiar pocket, carrying with him a supply of tow with which to make himself comfortable for the night. After all the family had retired to rest, a burglar made his appearance, effected an entrance, and proceeded to examine the pockets of the coat hanging to the door. Putting his hand rather unceremoniously into the squirrel's bedroom the robber received such a sharp and unexpected bite that he could not forbear to cry out and the master of the house, aroused by the unusual sound, entered the room, armed with a poker, just in time to secure the thief as he was escaping through the window. 
The Marmot.

Marmots are found in the northern parts of The Bobal. both the old and the new worlds. The Bobak The Prairie Dog: belongs to southern Russia, the Prairie Dog to North America and the Woodchuck to Canada. The marmot is easily tamed and is familiar to many from being made the companion of itinerant Savoyards who exhibit them when asking alms. The Bobak is also readily amenable to kindness. All these animals live in burrows and are exceedingly interesting in their habits. The anomalure is a squirrel with a membranous skin resembling to some extent that of the flying squirrels and used by it for the same purpose. It belongs to Fernando Po.

The

The Chinchilla is about nine inches long, its

Chinchilla. tail being about five inches. Its eyes are full, like those of the rabbit, its hind legs are long, its fore ones short. It sits upon its haunches, and takes its food in its fore paws. It is found in Chili and Peru, and inhabits the open country, living in burrows, and subsisting on the roots of bulbous plants, which are abundant in those regions. Great numbers of them are killed for their skins, which furnish the most delicate and beautiful of furs. The Alpine Viscacha and the Viscacha of the Pampas, are included in the same family.

The The Porcupine is found throughout Africa and Porcupine. southern Asia and also in the south of Europe. "Less completely covered with weapons of defence than the hedgehog," says Captain Brown, "the porcupine possesses them in greater strength, for its formidable quills are capable of inflicting severe wounds. When irritated or in danger it raises its quills on its back; but it is though fretful, not fierce in disposition but easily tamed." When cornered the porcupine turns its back to its assailant, who usually wounds himself by coming in contact with the quills. The porcupine lives in burrows by itself; it is a lonely animal. The Cavies and the Agouti of America are classified with this family. 
Among the former is the Capybara, the largest of the rodents, an animal which attains to from three to four feet in length. It belongs to Brazil, Guinea, and Paraguay. The Canadian porcupine, and the Brazilian porcupine, are tree porcupines and are only found in America.

The Guines The Guinea Pig (Cavia Cobaya) is said to be Pig. the domestic form of the Cavia Aperea of Brazil and Peru. It derives its name from its supposed place of origin, as it was said to have been first introduced into England from Guinea. It is tailless, but clean and neat in appearance, being marked with black, white, and orange colours. It is said to lack intelligence and to be destitute of attachment, suffering its young to be destroyed without resistance. Perhaps this is due to the fact that it has so many; it breeds at intervals of two months and produces from three to twelve young ones at a birth.

Hares and We come now to the second sub-order of the

Rabbits. Rodents or animals that gnaw, the Duplicidentati, the rodents having four incisor teeth in the upper jaw. This brings us to the Hares and Rabbits, of which there are numerous species, the Common Hare, the Irish or Mountain Hare and the Common Rabbit being the best known. The Irish or Mountain Hare is somewhat larger than the common hare and changes from brown to white in the winter. The Sardinian, the Egyptian, the Polar, and the Sage hares are other varieties.

The

The Common Hare is a familiar animal and Common needs no description. It is found throughout Fare. Europe and is well known in England. The hare hides during the day under cover of low foliage, ferns, and the undergrowth of preserves, in spots known as 'forms'. Its habit of making a definite track from its form to its feeding grounds and of always following its own track makes it an easy sacrifice to those who know its ways. It is exceedingly swift in its movements, and it is well that it is so, for its 
only safety is in flight and in the sagacity and cunning it shows in eluding its pursuers. Many illustrations of the latter have been recorded. Fouilloux mentions a hare which he saw start from its form at the sound of a hunter's horn, run towards a pool of water at a considerable distance, plunge in and swim to some rushes in the middle, and there lay down and conceal itself from the pursuit of the dogs. Another hare, when closely pressed passed under a gate, the dogs leaping over it. The hare quickly perceived the advantage it had gained by this, and so doubled, returning under the gate, the dogs following over it as before. This was repeated several times until taking advantage of the exhaustion of the dogs the hare escaped. The hare will often run perfectly straight while in view of the hounds, but immediately on gaining the slightest cover will double, and redouble with astonishing rapidity, apparently to confuse the scent.

The

The following anecdote seems to show remarkIntelligence able intelligence on the part of a hare. It is of the from a statement made by Mr. Yarrell in the Hare. "Magazine of Natural History":- "A harbour of great extent on our southern coast has an island near the middle, of considerable size, the nearest point of which is a mile distant from the mainland at high water, and with which point there is frequent communication by a ferry. Early one morning in spring two hares were observed to come down from the hills of the mainland towards the seaside, one of which from time to time left its companion, and proceeding to the very edge of the water, stopped there a minute or two, and then returned to its mate. The tide was rising, and after waiting some time, one of them, exactly at high water, took to the sea, and swam rapidly over, in a straight line, to the opposite projecting point of land. The observer on this occasion, who was near the spot, but remained unperceived by the hares, had no doubt that they were of different sexes, and that it was the male-like another Lean- 


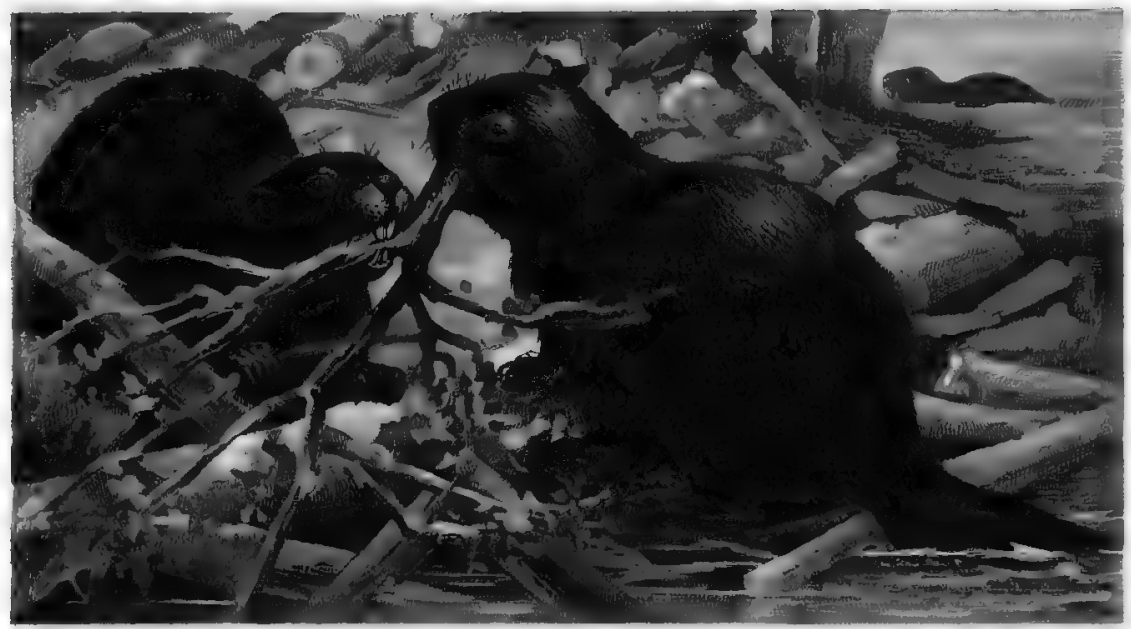

BEAVER

(Castor canadensis)

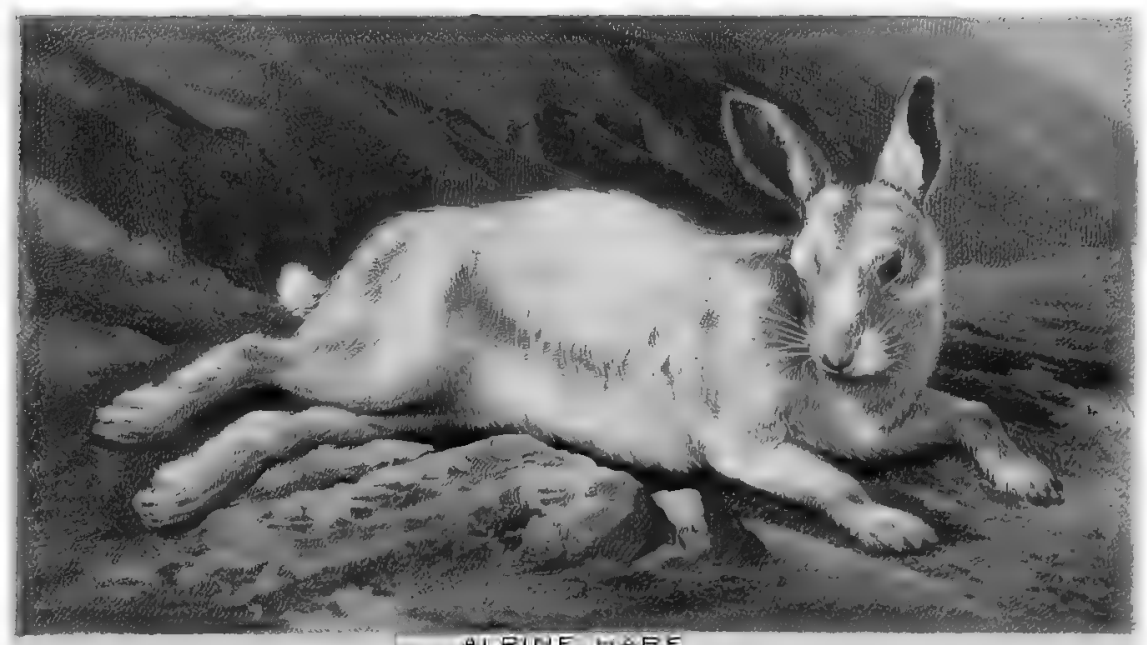


Digitized by Microsofte 
der-which swam across the water, as he had probably done many times before. It was remarkable that the hares had remained on the shore nearly half an hour, one of them occasionally examining, as it would seem, the state of the current, and ultimately taking to the sea at that precise period of the tide called slack water, when the passage across could be effected without being carried by the force of the stream either above or below the desired point of landing. The other hare then cantered back to the hills."

$\Delta$ Hunted The following story of a hunted hare is from Erare. "The Annals of Sporting," for May 1822:- "Two years ago, a doe hare produced two young ones in a field adjoining my cottage; and the three were occasionally seen, during the summer, near the same spot. But the leverets were, I have reason to believe, killed at the latter end of September of the same year; the old doe hare was also coursed, and making directly for my cottage, entered the garden, and there blinked the dogs. I repeatedly afterwards saw her sitting, sometimes in the garden, (which is one hundred and ten yards by forty-three,) but more frequently in the garden-hedge. She was repeatedly seen by greyhounds when she sat at some distance, but uniformly made for the garden, and never failed to find security. About the end of the following January, puss was no longer to be seen about the garden, as she had probably retired to some distance with a male companion. One day, in February, I heard the hounds, and shortly afterwards observed a hare making towards the garden, which it entered at a place well known, and left not the least doubt on my mind, that it was my old acquaintance, which, in my family, was distinguished by the name of Kitty. The harriers shortly afterwards came in sight, followed Kitty, and drove her from the garden. I became alarmed for the safety of my poor hare, and heartily wished the dogs might come to an irrecoverable fault. The hare burst away with the fleetness of the wind, and was followed breast high, by 
her fierce and eager pursuers. In about twenty minutes I observed Kitty return towards the garden, apparently much exhausted, and very dirty. She took shelter beneath a small heap of sticks, which lay at no great distance from the kitchen door. No time was to be lost, as, by the cry of the hounds, I was persuaded they were nearly in sight. I took a fishing-net, and, with the assistance of the servant, covered poor Kitty, caught her, and conveyed the little, panting, trembling creature into the house. The harriers were soon at the spot, but no hare was to be found. I am not aware that I ever felt greater pleasure than in thus saving poor Kitty from her merciless pursuers. Towards evening I gave Kitty her liberty; I turned her out in the garden, and saw her not again for some time. In the course of the following summer, however, I saw a hare several times, which I took to be my old friend; and, in the latter end of October, Kitty was again observed in the garden. Henceforward she was occasionally seen as on the preceding winter. One morning, in January, when I was absent, a gun was fired near my cottage; Kitty was heard to scream, but, nevertheless, entered the garden vigorously. The matter was related to me on my return home; and I was willing to hope that Kitty would survive. However, I had some doubt on the subject; and, the next morning, as soon as light permitted, I explored. the garden, and found that my poor unfortunate favourite had expired; she was stretched beneath a large gooseberry tree; and I could not help very much regretting her death."

Tame Hares. Though exceedingly timid creatures hares are readily tamed, and have often become as domesticated as cats and dogs. Cowper's experiments with hares will naturally occur to the reader, besides which there are cases recorded where tame hares have been associated in domesticity with cats and even sporting dogs. One possessed by Mr. A. S. Moffat was thus domiciled and would feed from 
the same plate with a cat and a dog. This hare would knock a book out of its master's hand to secure his attention.

The Common The Common Rabbit is found all over the Rabbit. British Isles, as well as in France and Spain; and in the north of Africa where it is indigenous. It is smaller than the hare and lives in burrows, in large numbers, completely honey-combing sand hills which are covered with grass and vegetation. Before producing her young, the female forms a separate burrow where she conceals them after birth. This is done to protect them from the male who destroys, if he discovers them. The young are born blind and gain their sight after ten days. They are a month old before they are allowed to leave the burrow.

ORDER XI. Curiously enough this order, though deToothless nominated toothless, includes several animals

Animals. which have well developed dental arrangements. In these, however, the teeth are not found in the front of the jaw, and those which are found are elementary and simple. Several families are classified with this order, of which the Sloth, the Pangolin, the Armadillo, the Cape AntBear, and the Ant-Eater are the best known representatives. The Bloth. The Sloth belongs to South America. "In its wild state," says Waterton, "the Sloth spends its whole life in the trees, and never leaves them but through force or accident, and, what is more extraordinary, not upon the branches, like the squirrel and monkey, but under them. He moves suspended from the branch, he rests suspended from the branch, and he sleeps suspended from the branch." "In fact," says the Rev. J. G. Wood, "as Sydney Smith observes, he passes a life of suspense, like a curate distantly related to a Bishop. To render it fit for this singular mode of life, its long and powerful arms are furnished with strong curved claws, which hook round the branches, and keep the animal suspended without any effort. When on the ground, these claws are very inconvenient, and it can barely shuffle 
along; but when it is in its native element, it moves with exceeding rapidity, particularly in a gale of wind, when it passes from branch to branch, and from tree to tree, with an activity which its movements on the ground by no means portend."

The There are two species of the Pangolin, or

Pangolin. Manis, the long-tailed and the short-tailed, the former being a native of Africa and the latter of the East Indies. The long-tailed manis measures about five feet inclusive of the tail which is about three feet long, the short-tailed manis about four feet in all. All the upper parts of its body are closely covered with scales of different sizes, which, as they are attached to the skin only by the lower extremity, it can erect at pleasure, opposing to its adversary a formidable row of offensive weapons. They are sharp at the point, and so hard as, on collision, to strike fire like a flint. The moment it perceives the approach of an enemy, it rolls itself up like a hedgehog, by which means it covers all the weaker parts of its body. The Pangolins live on ants, which they catch by thrusting their long slender tongues into the midst of their prey, their tongues being covered by a gummy saliva to which the ants adhere.

The

The Armadillo is a native of South America, Armadillo. in which country there are several varieties. They are all covered with a strong crust or shell, resembling, as the Rev. J. G. Wood puts it, "the modified plate armour" worn by men in the r6th century. They eat vegetables and insects, and do good work as scavengers. They burrow with great rapidity and when rolled up, after the manner of the hedgehog, are invulnerable to their ordinary enemies.

The Cape The Cape Ant-Bear belongs to the Cape of Ant-Bear. Good Hope. It differs from the ant-eaters of the western world in many ways, being a hairy animal without scales, its head resembling that of the deer kind, having long ears but no horns. The length of its body which is covered 
with bristles is about four feet, and its feet which are short, are furnished with strong claws which enable it to excavate the cavities in which it lives.

The Ant- The true Ant-Eater is found in the South Eater. American tropics. The Great Ant-Eater belongs to La Plata, the Little Ant-Eater to the Brazils. The Great Ant-Eater is four feet in length, without its tail, which is two feet six inches long. The true ant-eater like the Pangolin already described inserts its long tongue into the nest of the ant, catching its little victims in large numbers by the sticky mucus which covers its tongue.

ORDER XII. Of the several families classed in this order

Pouched the opossums and the kangaroos are the most

Animals. familiar. The Dasyures of Tasmania and the Bandicoots of Australia and New Guinea also belong to this order, as do the many varieties of the Phalanger of Australasia and those of the Wombat of Tasmania. The pouch is one of the most remarkable provisions of Nature, the young of the pouched animals being small and of imperfect form at birth and requiring the protection of the pouch for their sustenance and development.

The The common Opossum, which is a native of

Opossum. Virginia, is about the size of a badger. It is provided with a pouch, in which it carries its young, and into which they leap on the approach of danger. Its covering is a coat of long fur, of a dingy white colour. It feeds upon fish, birds, insects, and reptiles. Its tail is very muscular, and by this it hangs from the branches of trees and, watching its prey, lets itself fall upon its victions with great precision. Its hind feet are formed something like hands, by which it is enabled to climb with wonderful facility. The opossum when caught often simulates death so admirably that he deceives his captors and ultimately escapes them.

The The Kangaroo belongs to Australia and New

Kangaroo. Guinea. The length of its body is from four to 
five feet six inches; its fore legs are very short; its hind ones very long. Its tail is from three to four feet in length, and its strength is such, that a stroke of it will break a man's leg. The Kangaroo moves by great leaps or bounds of from twelve to twenty feet. It is covered with a short soft fur, of a reddish ash-colour. It feeds on vegetables, and has a pouch for its young, like the opossum. Mr. Cunningham says: "The Kangaroos make no use of the short fore legs, except in grazing. When chased, they hop upon their hind legs, bounding onward at a most amazing rate, the tail wagging up and down as they leap, and serving them for a balance. They will bound over gulleys and deep declivities, and fly right over the tops of low brush wood." There are several varieties of this animal; one of which, called the Rat Kangaroo, is only the size of a rabbit; another, called the Tree Kangaroo, can hop about on trees in an extraordinary manner and is furnished with curved claws, on its fore paws, similar to those of the sloth, by which he can lay hold of the branches.

Kangaroo Kangaroo hunting is a favourite Australian sport.

Hunting. It is not unattended with danger either to dogs or men, the sharp claws and powerful hind legs of the animal making it a formidable enemy at close quarters. Dawson in his "Present State of Australia" says: "A full-sized 'wool man" at bay always sits on his haunches, and when he rises to move forward, he stands four, or four and a half feet high. In this manner, he will, when pressed, meet a man, and hug and scratch him, if not to death, in such a way that he does not soon forget it. When hard pressed, and near to water, the 'kangaroo always takes it; if it be deep water, and the dogs follow him, one or the other is almost sure to be drowned. If a single dog, the kangaroo is nearly certain to come off victorious, by taking his assailant in his fore arms, and holding him under water till he is dead; but, if he has two dogs opposed to him, he is not left at liberty to hold either of his opponents long enough under water to drown him, and 

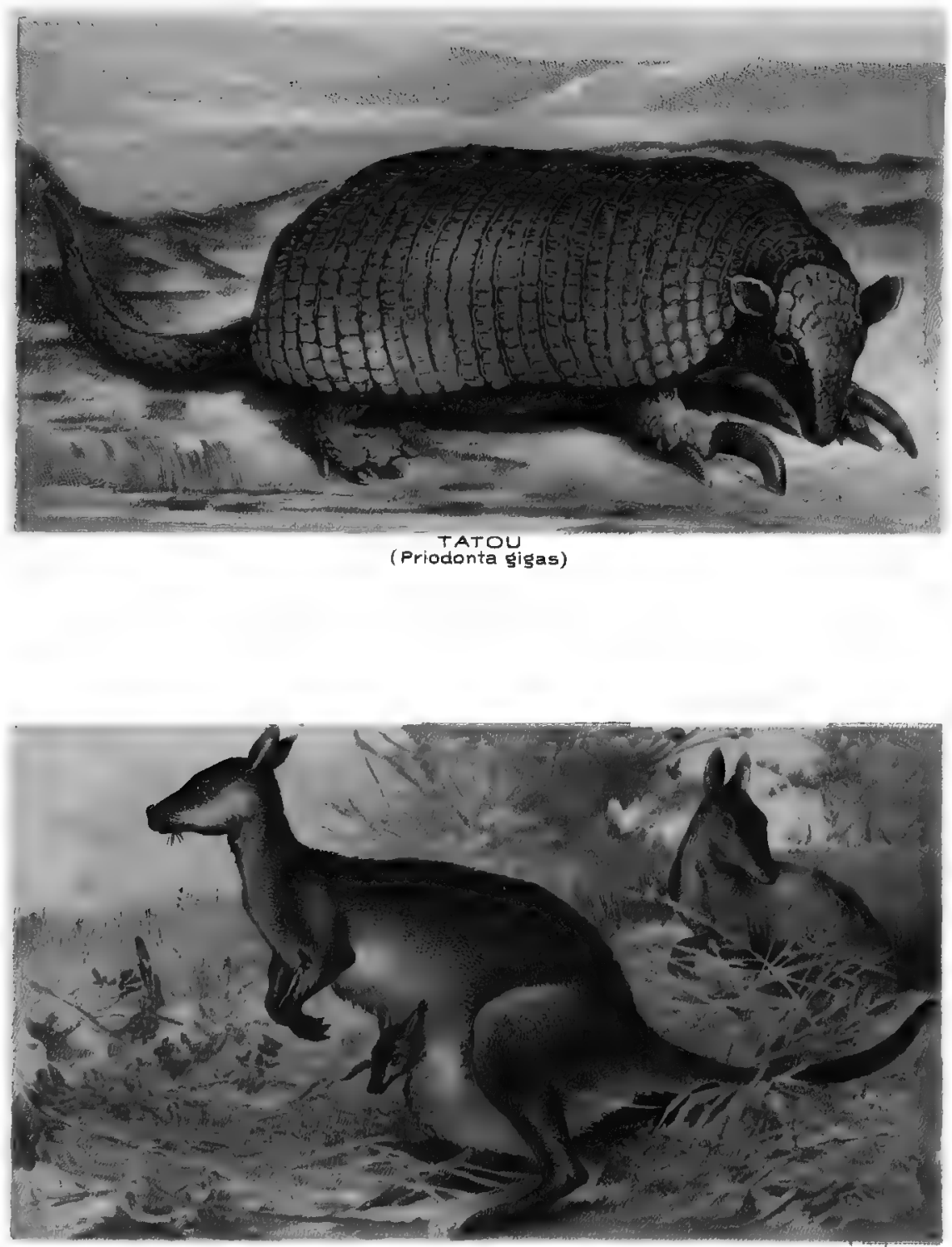
Digitized by Microsofte 
he generally himself falls a sacrifice, after a long and hard struggle. Notwithstanding the courage and ferocity of the kangaroo, when pressed, he is otherwise extremely timid, and more easily domesticated than any wild animal with which I am acquainted. The smaller ones are frequently quite as swift as a hare; and I have sometimes seen them outstrip the fleetest dogs." Young and inexperienced dogs are almost sure to fall victims to the sharp claw and powerful hind leg of the kangaroo, with one stroke of which he will rip the dog open and let his entrails out.

ORDER XIII. The order Monotremata includes two fami-

Monotremata. lies, the Ornithorhynchida and the Echidnida, both of which belong to Australia. The Duck-billed Platypus belongs to the former, the Australian Hedgehog to the latter family.

The

The Duck-billed Platypus is one if the most Duck-billed singular of animals. "When it was first introduced

Platyous. into Europe," says Mr. Wood, "it was fully believed to be the manufacture of some impostor, who with much ingenuity had fixed the beak of a duck into the head of some unknown animal. It will, however, be seen by examining the skull of the animal, that this duck-like beak is caused by a prolongation of some of the bones of the head." The Platypus lives on the banks of rivers in burrows which it forms, and feeds on water insects and small shell fish. It is web-footed but its feet are so constructed that it can fold back the web when it wants to burrow, and unfold it when it wants to swim. The hind feet of the male are armed with a sharp spur.

The The Australian Hedgehog is about a foot long. Australian It lives in burrows and feeds on insects, has a long Hodgehog. tongue but no teeth. It has spines from which circumstance it is called a hedgehog after its English namesake, though its spines are almost hidden by its hair. It is said to be a dull, unintelligent animal. 


\title{
THE ANIMAL KINGDOM.
}

\author{
SUB-KINGDOM VERTEBRATA.
}

\section{CLASS II-A VES.}

Classiflcation. The Birds are distinguished from the Mammals by many obvious characteristics, chief among which are their bodily form, their feathery covering and their manner of producing their young by means of eggs. The Birds form the second class of the sub-kingdom Vertebrata and according to the classification followed in this work are divided into ten orders. These orders are, I Passeres: birds characterised by the habit of perching; II Picaria: birds that climb, etc. III Psittacini : the Parrots; IV Columbæ: the Doves; V Gallinæ: the Fowls; VI Opisthocomi: the Hoazin of Brazil and Guinea; VII Accipitres: the Birds of Prey; VIII Grallatores: the birds that wade; IX Anseres: the Birds that swim; $\mathrm{X}$ Struthiones: the Ostrich, the Emu, etc., etc.

ORDER I. The species of this order are very numerous, and Perching have been variously divided by different authorities. Birds. Mr. Wallace forms them into five groups, which classification we shall find it convenient to follow. These five groups are: I The Thrushes and Thrush-like perching birds; II The Tanagers and similar kinds; III The Starlings and allied species; IV The Ant-eaters, etc., and V The Lyre Birds, and the Scrub Birds of Australia. The first group includes many well known feathered favourites: the Thrush; the Blackbird; the Mocking Bird; the Tailor Bird; the Wren; the Robin; the Nightingale; the Titmouse; the 
Golden Oriole; the Jay; the Magpie; the Raven; the Rook; the Carrion Crow ; the Jackdaw ; the Chough; and the Bird of Paradise. The second group includes the Swallow; the Martin; the Goldfinch; the Linnet; the Canary; the Bullfinch; the Bunting and many others. The third group contains the Starlings; the Weaver Bird; the Lark; the Wagtail, and the Pipits; the fourth group, the King Bird of North America; the Manakins of Guinea; the Chatterers of South America; the Bell Bird of Brazil, and the Umbrella Bird of the Amazon. The fifth group contains the Lyre Birds and the Scrub Birds of Australia.

The

The order of Thrush-like perching birds is a

Thrush. very large one, including nearly three thousand known varieties. Of these it will be impossible, within present limits, to even mention a very large number, and we shall content ourselves with dealing with a few of the better known species.

The Common The Thrush is one of the most popular of Thrush. English native birds, as its song is one of the most beautiful of those of the bird kind. It is a herald of the English spring and summer, beginning to sing at the end of January and continuing until July. It builds its nest in a hedge or bush, and, as it breeds early in the year, lines it with a plaster of mud to protect its young from the cold winds. It is a bold bird and will vigorously defend its nest from the attacks of larger birds. It feeds on insects, snails and worms.

"Watch an old thrush," says Dr. Stanley, "pounce down on a lawn, moistened with dew and rain. At first he stands motionless, apparently thinking of nothing at all, his eye vacant, or with an unmeaning gaze. Suddenly he cocks his ear on one side, makes a glancing sort of dart with his head and neck, gives perhaps one or two hops, and then stops, again listening attentively, and his eye glistening with attention and animation; his beak almost touches the ground,he draws back his head as if to make a determined peck. 
Again he pauses; listens again; hops, perhaps once or twice, scarcely moving his position, and pecks smartly on the sod; then is once more motionless as a stuffed bird. But he knows "well what he is about; for, after another moment's pause, having ascertained that all is right, he pecks away with might and main, and soon draws out a fine worm, which his fine sense of hearing had informed him was not far off, and which his hops and previous peckings had attracted to the surface, to escape the approach of what the poor worm thought might be his underground enemy, the mole."

The Missel The Missel Thrush, so called from its fondness

Thrush. for the mistletoe, is larger than the common or song thrush, less melodious and not so common in England, but well known upon the continent of Europe. Like the song thrush it finds a determined enemy in the magpie, against which it often defends itself with success. It is, however, unable to withstand a combined attack. Gilbert White says: "The Missel-thrush is, while breeding, fierce and pugnacious, driving such birds as approach its nest with great fury to a distance. The Welsh call it "pen y llwyn," the head or master of the coppice. He suffers no magpie, jay, or blackbird, to enter the garden where he haunts; and is, for the time, a good guard to the new-sown legumens. In general, he is very successful in the defence of his family; but once I observed in my garden, that several magpies came determined to storm the nest of a missel-thrush: the dams defended their mansion with great vigour, and fought resolutely pro aris et focis; but numbers at last prevailed, they tore the nest to pieces, and swallowed the young alive."

The The Blackbird is another of the most cherished Blackbird. of English song birds. It is one of the earliest to wake the morning with a song. Its habits are similar to those of the Thrush; it builds its nest in bushes, in shrubberies and gardens, safe from the sight, but close to the haunts of man. It lines its nest with a plaster of mud which it covers 
over with dry grass, and is exemplary in the care of its young. It has a black coat as its name implies, and an orange tawny bill. The blackbird has to some extent the power of the mocking bird, of imitating the sounds it hears,-such as the chuckling of a hen, the song of the nightingale, the caw of the crow. In the "Magazine of Natural History" of September 1831, Mr. Bouchier of Wold Rectory, near Northampton, says: "Within half a mile of my residence there is a blackbird which crows constantly, and as accurately as the common cock, and nearly as loud; as it may, on a still day, be heard at the distance of several hundred yards. When first told of the circumstance, I conjectured that it must have been the work of a cock pheasant, concealed in a neighbouring brake; but, on the assurance that it was nothing more or less than a common blackbird, I determined to ascertain the fact with my own eyes and ears; and this day $I$ had the gratification of getting close to it, seated on the top bough of an ash tree, and pursuing with unceasing zeal its unusual note. The resemblance to the crow of the domestic cock is so perfect, that more than one in the distance were answering it. It occasionally indulged in its usual song; but only for a second or two; resuming its more favourite note; and once or twice it commenced with crowing, and broke off in the middle into its natural whistle. In what way this bird. has acquired its present propensity I am unable to say, except that as its usual haunt is near a mill where poultry are kept, it may have learned the note from the common fowl."

The Blackbird of America resembles his English cousin in most particulars. $\mathrm{He}$ is often seen following the plough, looking for worms in the fresh furrows, and frequently, like the crow, stealing the planted maize or Indian corn from the hill. In the autumn the American Blackbirds gather in vast flocks, and sometimes produce a roar like the rush of a waterfall by their flight. 
The

The Mocking Bird is a native of America and Mooking many stories are told of its wonderful powers

Bird. of mimicry. The following description is furnished by Wilson: "The plumage of the Mocking Bird, though none of the homeliest, has nothing gaudy or brilliant in it, and, had he nothing else to recommend him, would scarcely entitle him to notice; but his figure is well proportioned, and even handsome. The ease, elegance, and rapidity of his movements, the animation of his eye, and the intelligence he displays in listening, and laying up lessons from almost every species of the feathered creation within his hearing, are really surprising, and mark the peculiarity of his genius. In his native groves, mounted upon the top of a tall bush or half grown tree, in the dawn of a dewy morning, while the woods are already vocal with a multitude of warblers, his admirable song rises pre-eminent over every competitor. The ear can listen to his music alone, to which that of all the others seems a mere accompaniment. Neither is this strain altogether imitative. His own native notes, which are easily distinguishable by such as are acquainted with those of our various song birds, are bold and full, and varied seemingly beyond all limits. They consist of short expressions of two, three, or at the most five or six syllables, generally interspersed with imitations, and all of them uttered with great emphasis and rapidity, and continued with undiminished ardour for half an hour, or an hour, at a time. His expanded wings and tail, glistening with white, and the buoyant gaiety of his action, arresting the eye, as his song most irresistibly does the ear, he sweeps round with enthusiastic ecstasy and mounts and descends as his song swells or dies away. ' $\mathrm{He}$ bounds aloft with the celerity of an arrow, as if to recover or recall his very soul, which expired in the last elevated strain.' He often deceives the sportsman, and sends him in search of birds that are not perhaps within miles of him, but whose notes he exactly imitates: even birds themselves are 
frequently imposed upon by this admirable mimic, and are decoyed by the fancied calls of their mates, or dive with precipitation into the depth of thickets at the scream of what they suppose to be the sparrow-hawk."

The Tailor The Tailor Bird is a small bird of no very

Bird. remarkable appearance, but it is singular from its habit of sewing leaves together in forming its nest. This it does by using its beak as a needle, and certain vegetable fibres as thread, and sewing the edges of leaves together in the form of a pocket, in which it deposits its eggs and rears its young. The Golden The Golden Crested Wren is the smallest Crested Wren. of British Birds, and it is one of the most beautiful, acccording to Mrs. Bowdich it only weighs eighty grains. It is peculiar among British birds for suspending its nest to the boughs of trees. Its nest is an elegant structure, sometimes open at the top, sometimes covered with a dome, having an entrance at the side. It is a tame bird, and often visits country gardens where it may be distinguished by its green and yellow coat with white facings, and its golden crest. Captain Brown says: "its song is weak and intermittent, yet sweet as that which fancy attributes to the fairy on the moonlight hill."

The

Captain Brown, quoting from "Selby's OrnithoMigration logy", gives an interesting account of the way in of Birds. which our native birds are reinforced from other countries. - "On the 24th and 25th of October, 1822," says Mr. Selby, "after a very severe gale, with thick fog, from the North East, (but veering, towards its conclusion, to the east and south of east,) thousands of these birds were seen to arrive upon the sea-shore and sand-banks of the Northumbrian coast; many of them so fatigued by the length of their flight, or perhaps by the unfavourable shift of wind, as to be unable to rise again from the ground, and great numbers were in consequence caught or destroyed. This flight must have been immensely numerous, as its extent was traced through the whole length of the coasts of Northumberland 
and Durham. There appears little doubt of this having been a migration from the more northern provinces of Europe (probably furnished by the pine forests of Norway, Sweden, \&c.), from the circumstance of its arrival being simultaneous with that of large flights of the woodcock, fieldfare, and redwing. Although I had never before witnessed the actual arrival of the gold-crested regulus, I had long felt convinced, from the great and sudden increase of the species, during the autumnal and hyemal months that our indigenous birds must be augmented by a body of strangers making these shores their winter's resort.-A more extraordinary circumstance $i_{n}$ the economy of this bird took place during the same winter, viz., the total disappearance of the whole, natives as well as strangers, throughout Scotland and the north of England. This happened towards the conclusion of the month of January 1823 , and a few days previous to the longcontinued snow-storm so severely felt throughout the northern counties of England, and along the eastern parts of Scotland. The range and point of this migration are unascertained, but it must probably have been a distant one, from the fact of not a single pair having returned to breed, or pass the succeeding summer, in the situations they had been known always to frequent. Nor was one of the species to be seen till the following October, or about the usual time, as I have above stated, for our receiving an annual accession of strangers to our own indigenous birds."

The

The Willow Wren is a summer visitor to the Willow British Isles. He arrives about the end of March Wren. and leaves in the month of September. He is an active little bird, an expert fly-catcher and an agreeable singer. His coat is of a greenish yellow-brown, his waistcoat is white tinged with yellow.

The

The Common Wren is indigenous to Great Common Britain. It builds its nest under the shelter of Wren. thatched eaves, in out-of-the-way and unusual 
places. It is a plain homely looking little bird of a pale chestnut brown colour. Captain Brown gives the following interesting description of a wren's music lesson.

A Wren's "A pair of wrens," says Captain Brown, "built Music Lesson. their nest in a box, so situated that the family on the grounds had an opportunity of observing the mother's care in instructing her young ones to sing. She seated herself on one side of the opening of the box, facing her young, and commenced by singing over all her notes very slowly and distinctly. One of the little ones then attempted to imitate her. After chirping rather inharmoniously a few. notes, its pipe failed, and it went off the tune. The mother immediately took up the tune where the young one had failed, and distinctly finished the remaining part. The young one made a second attempt, commencing where it had left off, and continuing for a few notes with tolerable distinctness, when it again lost the notes; the mother began again where it ceased, and went through with the air. The young one again resumed the tune and completed it. When this was done, the mother again sung over the whole of her song with great precision; and then another of the young attempted to follow it, who likewise was incapable of going through with the tune, but the parent treated it as she had done the first bird; and so on with the third and fourth. It sometimes happened that the little one would lose the tune, even three or four times in making the attempt; in which case the mother uniformly commenced where it had ceased, and always sung to the end of the tune; and when each had completed the trial, she always sung over the whole song. Sometimes two of them commenced the strain together, in which case she pursued the same conduct towards them, as she had done when one sung. This was repeated at intervals every day, while they remained in their nest."

The

The American House Wren is described by Bouse Wren. Audubon as a cheery familiar little bird, resem- 
bling the common wren in many of his habits, if not indeed identical with it.

Wilson says, "in the month of June a mower hung up his coat, under a shed, near the barn, and two or three days elapsed before he had occasion to put it on again, when thrusting his arm up the sleeve, he found it completely filled with some rubbish, as he called it, and on extracting the whole mass, found it to be the nest of a wren completely finished, and lined with a large quantity of feathers. In his retreat, he was followed by the forlorn little proprietors, who scolded him with great vehemence for thus ruining the whole economy of their household affairs." Wilson also tells a very pretty story of a pair of wrens who built their nest upon a window sill, one of whom, the female, venturing to enter the room was devoured by a cat. The male bird showed much uneasiness when he missed his mate, but after a time disappeared for two days, returning with a new wife, and with her help removing the two eggs left by her predecessor to a new nest in a more secure position.

The The Nightingale and the Sky-Lark, may perhaps Nightingale. be said to divide honours in the sphere of feathered song. Both have entranced innumerable auditors and both have won noble tributes from poets' pens. Both, moreover, are plain birds. The nightingale is of a tawny colour on the head and back, and of a greyish white on the throat and under parts. It has a full large eye of great brightness. It is one of the largest of the song birds, measuring seven inches in length. The nightingale is found in Yorkshire but not in Lancashire, also in Surrey, Sussex, Kent, Dorsetshire, Somersetshire and East Devonshire, but not in Cornwall. It belongs to France, Germany, Poland, Italy, and Palestine.

The "The Nightingale's song," says the author of Nighingale's "Tales of Animals," unites strength and sweetness, song. in a most wonderful degree, as its notes may be heard on a calm evening at the distance of half a mile. 
Plate No. 14
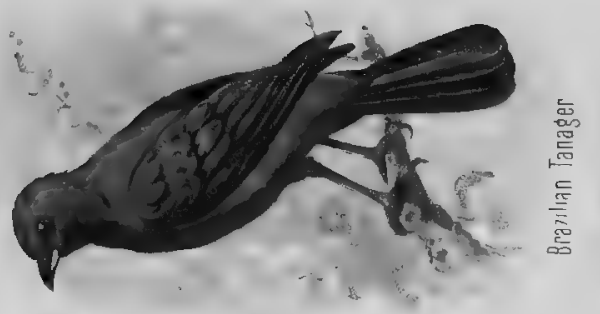

MILES' NATURAL HISTORY.
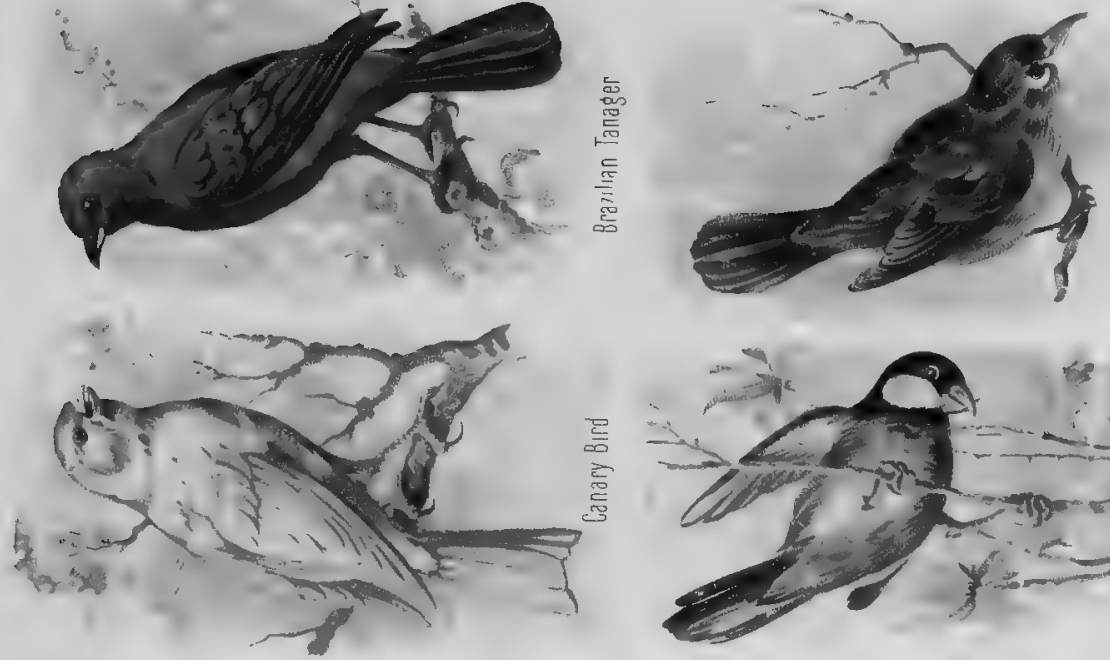

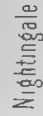
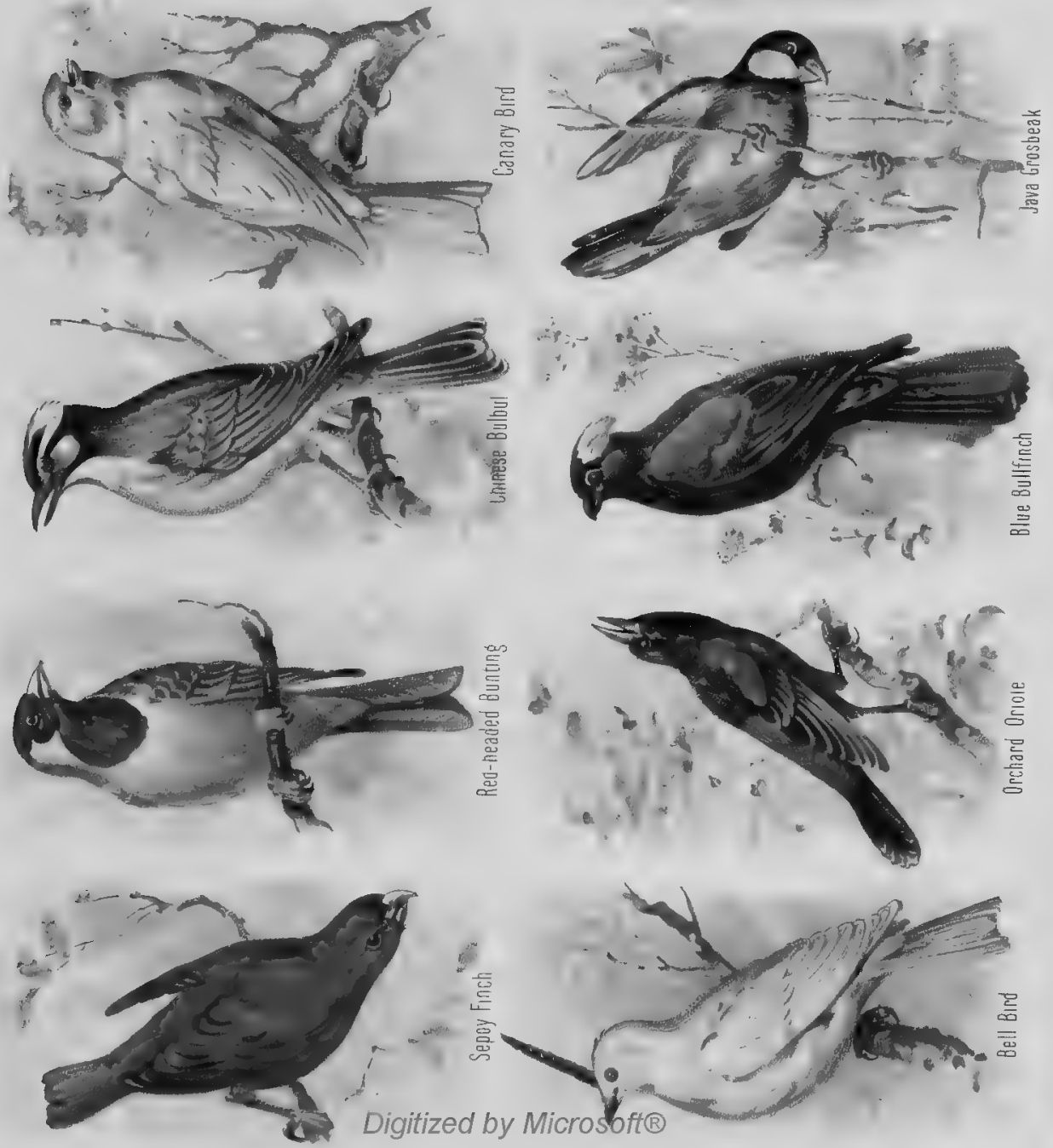
Digitized by Microsofte 
The most consummate musician might listen with delight to its song, whatever might be his peculiar taste, as it can at one moment thrill the heart with joy and at another melt it to sober sadness, by the laughing and sighing modulations which follow each other in rapid succession through the melody, which is seldom interrupted by a pause. As if conscious of its unrivalled powers, it does not join the sometimes discordant concert of the other songsters, but waits on some solitary twig till the blackbird and thrush have uttered their evening call, till the stock and ring doves have lulled each other to rest, and then it displays at full its melodious fancies." The following is an attempt made by a well-known naturalist to reduce the song to writing:

"Tiuu tiuu tiuu tiuu-Spe tiuu zqua-Tīo tiō tió tio tio tio tio tix-Qutio qutio qutio qutio-Zquo zquo zquo zquoTzü tzü tzü tzü tzỉ tzỉ tzü tzü tzü tzi-Quorror tiu zqua pipiquisi-Zozozozozozozozozozozozo zirrhading! " \&c. \&c.

Quaint old Izaac Walton says: "But the nightingale, another of my airy creatures, breathes such sweet, loud music out of her instrumental throat, that it might make mankind to think that miracles are not ceased. He that at midnight, when the very labourer sleeps securely, should hear, as I have very often, the clear airs, the sweet descents, the natural rising and falling, the doubling and redoubling of her voice, might well be lifted above earth, and say, 'Lord', what music hast thou provided for the saints in Heaven, when thou affordest bad men such music on earth!" "

The Robin The Robin Redbreast is a prime favourite in

Redbreast. English cottage homes. Its appearance on the window sill at the approach of winter is an irresistible appeal to human sympathy and seldom fails of a hearty response. Captain Brown mentions a robin which, during a severe storm, came to the window of the room where his father sat, upon which his father opened the window, to give it some crumbs. "Instead of flying away, the robin hopped into the room, 
and picked the crumbs from the floor. His father, being very fond of animals, took great pleasure in taming this bird, and so completely succeeded, that it would pick small pieces of raw flesh and worms from his hand, sat on the table at which he wrote, and, when the day was very cold, perched upon the fender. When a stranger entered, it flew to the top of a door, where it perched every night. The window was frequently opened to admit air, but the robin never offered to go away. As the spring advanced, and the weather became fine, it flew away every morning, and returned every evening, till the time of incubation arrived, and it then flew away altogether. At the next fall of the year it again asked for admittance, and behaved exactly in the same manner as before. It did this a third time, but when it flew away the ensuing spring, it was never seen again." Robins have been known to build their nests in queer places. Mrs. Bowdich tells of one which attached its nest to the Bible of the parish church of Hampton, Warwickshire, and of others which built theirs on the reading desk of a church in Wiltshire and deposited six eggs in it.

The Intelligence The Robin is an intelligent little bird and of the Robin. some pretty stories are told of its sagacity. Mrs. Bowdich mentions a gardener who was in the service of a friend of hers, who having made a pet of a robin, was one day much struck with the uneasiness of his little friend, and concluding that he wanted assistance followed him to his nest, which occupied a flower pot, when he discovered that a snake had coiled itself round the little home. Happily the gardener was in time to save the birds though at the snake's expense. In “The Gardener's Chronicle" there is a story, quoted by Mrs. Bowdich, of a robin which having been caught young and kept with a nightingale, learned the nightingale's song so perfectly as to be indistinguishable in verformance.

The Titmouse. There are several varieties of the Titmouse; 
the Blue Titmouse, the Great Titmouse, and the Long-tailed Titmouse are some of these. The Blue Titmouse, sometimes called a Tomtit, is a plucky little bird and resists capture with such vigour that according to the Rev. J. G. Wood it has become known to rustic boys by the name of "Billybiter." "The angry hiss of the female," says Mr. Wood, "has frequently caused an intruding hand to be rapidly withdrawn, for the sound is so exceedingly like the hiss of an irritated snake, and the little beak is so sharp, that few have the courage to proceed with their investigations. A pair of these birds built their nest in the coping of the Great Western Railway, at the Shrivenham station, not two feet from the fiery and noisy engines, which were constantly passing. The men respected the courage of the little birds, and the whole brood was hatched, and suffered to fly at liberty."

The Great Titmouse is found in various parts of Europe. According to Mrs. Bowdich it is sufficiently pliable to roll itself up in a ball, and is strong enough to crack a hazel nut. She says, "It will plant itself at the door of a hive, and tap loudly on the edge; which signal is answered by a sentinel bee who is immediately snapped up, taken to the bough of a tree where he is beaten to death, and then loses his head and thorax; the rest of him being unworthy of the appetite of his captor." The Long-tailed Titmouse is famous for the beauty, security and warmth of its nest.

The Golden The Golden Oriole deserves mention if only

Oriole. for its beautiful name; it has, however, other claims to attention. It is found in Europe and Australia and visits England occasionally during the summer, but is not found in America. The male is a very handsome bird of a golden yellow colour, with wings and tail of black, the feathers of the latter ending in yellow. It lives on fruit and berries, and, failing these, insects, and inhabits thickets and wooded spots adjacent to orchards, upon which it commits serious depredations. 
The Bhrike. There are several species of Shrikes, the Thick-headed Shrike, the Great Shrike, and the Red-backed Shrike being among these. The Great Shrike belongs to both Europe and America. In appearance it resembles the Mocking Bird for which it is sometimes mistaken. It preys upon mice, frogs, birds, grasshoppers and large insects, killing and then impaling them upon thorns until such time as it chooses to eat them. Its rapacity has earned for it the name of "the Butcher Bird." According to $\mathrm{Mr}$. Bell these birds are kept tame in the houses in Russia. One in his possession was furnished with a sharply pointed stick for a perch, on the end of which it spitted any bird or animal it caught. The Shrike believes in a well filled larder, and does not proceed to eat his game until he has a good stock. $\mathrm{He}$ is also known as the "Nine-killer" in America, from his supposed preference for spitting that number at a forage.

The Jay. We now come to the family of the Corvidæ, the crow family, which includes the Jays, the Magpies and the Choughs. The Common Jay is indigenous in England where it secludes itself in woody fastnesses, rarely exposing itself in open country. It is a handsome bird about thirteen inches long, with beautiful blue markings on its wings, but is so shy that it is difficult to get a sight of it when at liberty. Taken young it may be easily tamed, when it becomes an amusing, if mischievous pet. It has considerable powers of mimicry and can imitate the common sounds it hears with wonderful exactness. The bleat of the lamb, the mew of the cat, the neigh of the horse and the cries of other birds give exercise to this faculty, and Bewick says: "We have heard one imitate the sound made by the action of a saw, so exactly, that though it was on a Sunday, we could hardly be persuaded that the person who kept it had not a carpenter at work in the house." Like many other birds it becomes bold in the care and protection of its young. Knapp in his "Journals of a Naturalist" says : 

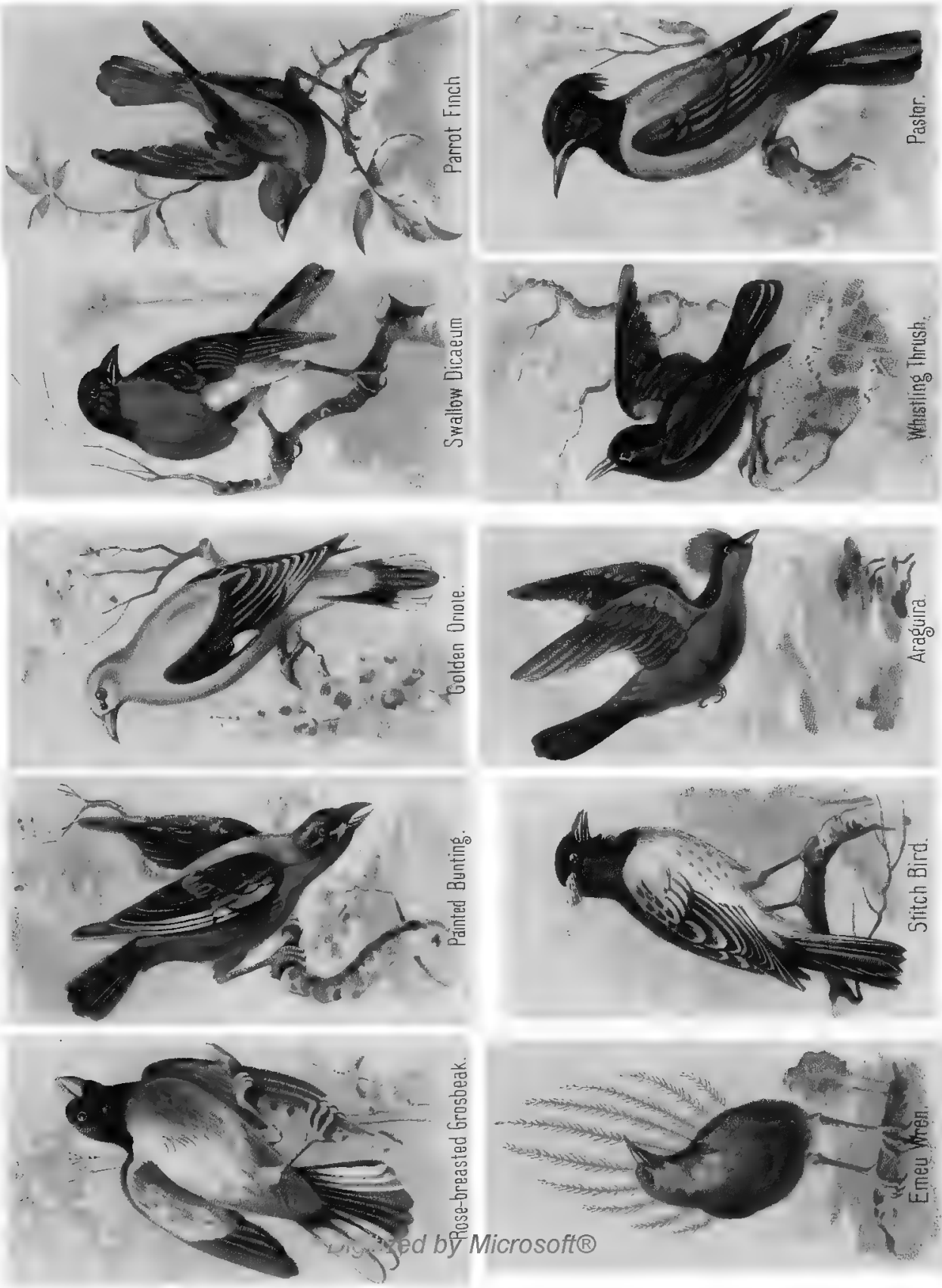
Digitized by Microsofte 
"This bird is always extremely timid, when its own interest or safety is solely concerned; but no sooner does its hungry brood clamour for supply, than it loses all its wary character, and becomes a bold and impudent thief. At this period it will visit our gardens, which it rarely approaches at other times, plunder them of every raspberry, cherry, or bean, that it can obtain, and will not cease from rapine as long as any of the brood or the crop remains. We see all the nestlings approach, and, settling near some meditated scene of plunder, quietly await a summons to commence. A parent bird from some tree, surveys the ground, then descends upon the cherry, or into the rows, immediately announces a discovery, by a low but particular call, and all the family flock into the banquet, which having finished by repeated visits, the old birds return to the woods, with all their chattering children, and become the same wild, cautious creatures they were before."

The Blue Wilson gives the following description of the Jay. Blue Jay: "This elegant bird, peculiar to North America, is distinguished as a kind of beau among the feathered tenants of the woods, by the brilliancy of his dress; and like most other coxcombs, makes himself still more conspicuous by his loquacity, and the oddness of his tones and gestures. Of all birds he is the most bitter enemy to the owl. No sooner has he discovered the retreat of one of these, than he calls the whole feathered fraternity to his assistance, who surround the glimmering recluse, and attack him froin all sides, raising such a shout as may be heard on a still day more than half a mile off. The owl at length, forced to betake himself to flight, is followed by his whole train of persecutors, until driven beyond the boundaries of their jurisdiction. But the blue jay himself is not guiltless of similar depredations as the owl and becomes in his turn the very tyrant he detested, and he is sometimes attacked with such spirit as to be under the necessity of making a 
speedy retreat. The blue jay is not only bold and vociferous, but possesses a considerable talent for mimicry, and seems to enjoy great satisfaction in mocking and teasing other birds, particularly the little hawk, imitating his cry whenever he sees him, and squeaking out as if caught; this soon brings a number of his own tribe around him, who all join in the frolic, darting about the hawk, and feigning the cries of a bird sorely wounded, and already in the clutches of its devourer; while others lie concealed in bushes, ready to second their associates in the attack. But this ludicrous farce often terminates tragically. The hawk, singling out one of the most insolent and provoking, swoops upon him in an unguarded moment, and offers him up a sacrifice to his hunger and resentment. In an instant the tune is changed, all their buffoonery vanishes, and loud and incessant screams proclaim their disaster. Whenever the jay has had the advantage of education from man, he has not only shown himself an apt scholar, but his suavity of manners seems equalled only by his art and contrivances, though it must be confessed that his itch for thieving keeps pace with all his other acquirements."

The The Magpie is an ancient bird and is men-

Magpie. tioned by Plutarch and other early writers. It is indigenous in England and shows great industry and ingenuity in the construction of its nest, which it lines with mud plaster and covers with thorns, building upon high trees and in secluded spots. It feeds upon both animal and vegetable food, attacking birds, young ducks and chickens, as well as mice and even rats, and regaling itself on both fruit and grain. It attains to a length of about eighteen inches and is a handsome bird, though captivity does not improve its appearance.

The Magpie's The mischievous habits of the magpie have Mischiof. won for it the name of "the Monkey of the Birds," the Raven as Mr. Wood puts it being "the rnitho- 
logical baboon." Its mischief is displayed in many ways; in the wanton destruction of articles and in their crafty secretion, as well as in the thievish appropriation of edible dainties. Mr. Wood tells of a Wiltshire magpie which " found a malicious enjoyment in pecking the unprotected ankles of little boys not yet arrived at manly habiliments, and was such a terror to the female servants that they were forced to pass his lurking-place armed with a broom. One of the servants having neglected this precaution, was actually found sitting down on the stones to protect her ankles, the magpie triumphantly pacing round her, until aid was brought, and the bird driven away." Mrs. Bowdich quotes the following from Mr. Ranson: "A magpie, kept by a branch of our family, was noted for his powers of imitation. He could whistle tunes, imitate hens and ducks, and speak very plainly. Seated upon a toll-bar gate, he would shout 'Gate, ahoy!' so distinctly, as to draw out the keeper, who was generally saluted by a loud laugh when he answered the call. When the keeper's wife was making pastry, he would practise the same manœuvre, and if the trick were not detected, and the woman rushed out to open the gate, the magpie darted into the house, and speedily made his exit with his bill full of paste; and he, in great glee, would chatter about it for some time afterwards. He would perch upon the backs of chairs, say he was hungry, or inform the juniors of the family it was time to go to school. He was allowed to run about, but was never out of mischief, and had a constant propensity to pilfer and hide small articles." Of the serious consequences sometimes attending this habit of secreting things, the following story from Lady Morgan's "Italy" is a painful illustration. - " A noble lady of Florence, resided in a house which stands still opposite the lofty Doric column which was raised to commemorate the defeat of Pietro Strozzi, and the 'taking of Sienna, by the tyrannic conqueror of both. Cosmo, the First, lost a valuable pearl necklace, and one of her 
waiting-women, (a very young girl) was accused of the theft. Having solemnly denied the fact, she was put to the torture, which was then a plaisir at Florence. Unable to support its terrible infliction, she acknowledged that 'she was guilty,' and, without further trial, was hung. Shortly after, Florence was visited by a tremendous storm; a thunder-bolt fell on the figure of Justice, and split the scales, one of which fell to the earth, and with it fell the ruins of a magpie's nest, containing the pearl necklace. Those scales are still the haunts of birds, and I never saw them hovering round them, without thinking of those 'good old times,' when innocent women could be first tortured, and then hung on suspicion."

The The Raven is a large bird, indeed the largest

Raven. of the British crows, attaining to a length of two feet two inches, and having a stretch of wing of four feet eight inches, in width. It is an historic bird, being mentioned by Pliny who records that a tame one kept in the Temple of Castor, was taught by a tailor whom it used to visit, to pronounce the name of the Emperor Tiberius and of the other members of the Royal family. The fame of the bird brought the tailor riches, but excited the jealousy of his neighbours, one of whom killed the bird. The record states that the offender was punished and the bird accorded a magnificent funeral. The Raven builds its nest in high trees and among inaccessible and precipitous rocks, especially in the Hebrides, and lives on carrion, not disdaining fruit and grain. Like many other birds who afterwards show little concern for their young the Raven is assiduous in its attentions during the period of incubation. The following is from White's "Natural History of Selborne" :

"In the centre of a grove near Selborne, there stood an oak, which though shapely and tall on the whole, bulged out into a large excrescence near the middle of the stem. On the tree a pair of ravens had fixed their residence for such a series of years, that the oak was distinguished by the name 
of the 'raven tree.' Many were the attempts of the neighbouring youths to get at this eyrie; the difficulty whetted their inclinations, and each was ambitious of surmounting the arduous task; but, when they arrived at the swelling, it jutted out so much in their way, and was so far beyond their grasp, that the boldest lads were deterred, and acknowledged the undertaking to be too hazardous. Thus the ravens continued to build nest after nest, in perfect security, till the fatal day arrived on which the wood was to be levelled. This was in the month of February, when these birds usually sit. The saw was applied to the trunk, the wedges were inserted in the opening, the woods echoed to the heavy blows of the beetle or mallet, the tree nodded to its fall; but the dam persisted to sit. At last, when it gave way, the bird was flung from her nest; and though her maternal affection deserved a better fate, was whipped down by the twigs, which brought her dead to the ground." Ravens are said to pair for life and to live for a hundred years.

Unnatural Though models of conjugal fidelity, Ravens

Parents. are said to be very unnatural parents, often showing not only indifference but cruelty to their young. Mr. Morris in his "Anecdotes of Natural History" tells an interesting story of a family of ravens whose mother came to an untimely death. "For a time the surviving parent hovered about the nest, uttering loud and menacing croakings whenever anybody approached. At length, however, he disappeared, and absented himself for two or three days, and then returned with another mate, when a strange scene occurred. The poor half-starved nestlings were attacked without mercy by the step-mother, who, after severely wounding, precipitated them from the nest; two, however, were found at the foot of the tree with signs of life, and with great care and attention reared at the rectory, about half a mile distant, and after being slightly pinioned, were allowed their liberty; but they seldom quitted the lawn or 
offices, roosting in a tree in the shrubbery. Here, however, they were soon discovered by their unnatural parents, who for a long time used to come at early dawn and pounce upon them with fierce cries." In this case it was the stepmother and not the mother that treated the young ravens so unkindly, and the father may be charitably credited with acting under the influence of his second wife. That the Raven drives its young out of its nest as soon as they are able to provide for themselves is true, but why they should pursue them after they have become independent is not clear. This habit of the ravens, as Mr. Morris points out, may be referred to in the following quotations: "He giveth to the beast his food, and to the young ravens which cry" (Psalm CXLVII. 9). "Who provideth for the raven his food? when his young ones cry unto God, they wander for lack of meat" (Job xxxviII. 4I).

The Tame The Raven may be easily tamed, and in pri-

Raven. vate life is always an amusement, if sometimes an annoyance. Like all birds which are capable of imitating sounds and which learn words and phrases it will often "speak its lines," with startling appropriateness as to time and place. Captain Brown tells a good story of a Raven which belonged to a gentleman who resided on the borders of the New Forest in Hampshire. On one occasion a traveller who was passing through the forest was startled by the frequent repetition of the words: "Fair play, gentlemen! fair play! for God's sake, gentlemen, fair play!" and upon tracing the source of the sound discovered the tame raven defending himself from the attacks of two of his own species. It is needless to say that the traveller rescued the "gentleman" from the two "ruffians" who molested him. Captain Brown also tells of a tame raven who was an expert rat-catcher and whose method was to place a meat bone in front of a rat hole and to stand on a ledge above the hole, pouncing on the rat as soon as he emerged from 
his retreat. In this way he captured as many as six in a fore-noon.

The Raven Dr. Stanley tells the following story of a and the Dog. Raven and a Dog: "A strong attachment was once formed between a raven and a large otter-dog. The raven had been taken when young, and reared in a stable-yard, where the dog was kept chained up. A friendship. soon commenced, which, increasing from little to more, in time ripened into a most extraordinary degree of intimacy. At first the bird was satisfied with hopping about in the vicinity of the kennel, and occasionally pecking a hasty morsel from the dog's feeding-pan when the latter had finished his meal. Finding, however, no interruption on the part of his friend, the raven soon became a constant attendant at meal times, and, taking up his position on the edge of the dish, acted the part of a regular guest and partaker of the dog's dinner, which consisted usually of meal and milk, with occasional scraps of offal meat, a piece of which the bird would often snatch up, almost from the very mouth of the dog, and hasten beyond the reach of his chain, as if to tantalise his four-footed friend; and then hopping towards him, would play about, and hang it close to his nose; and then as speedily, at the moment the dog was preparing to snap it up, would dart off beyond the reach of the chain. At other times he would hide the piece of meat under a stone, and then coming back, with a cunning look, would perch upon the dog's head. It was observed, however, that he always ended his pranks by either sharing or giving up the whole piece to his friend the dog. By some accident the raven had fallen into a tub of water, and, either weakened by struggling, or unable to get out owing to its feathers being soaked with water, it was nearly drowned. The dog (whether the same dog or another does not appear), chained at a short distance, saw the poor bird's danger, and dragging his heavy kennel towards it, reached his head over the side of the tub, 
and taking the drowning raven up in his mouth, laid him gently on the ground, when he soon recovered."

Tho Rook. The Rook which is often confused with the Carrion Crow is found in many parts of Europe and is abundant in England, where it is common to see groups of trees near gentlemen's houses given up to their occupancy. Here they build their nests, rear their young, keep up an incessant cawing, quarrel and make peace as do all other large communities. If a new-comer appears among them, he is generally received in a very rough manner. At Newcastle, a pair of rooks attempted to introduce themselves into a rookery, but were so rudely treated, that, in high dudgeon, they ascended to the steeple of one of the public buildings, and built their nest on the vane. Here they lived for several successive seasons, turning about with every change of wind, and regardless of the busy scene in the town beneath. The rook is gregarious, in which particular it differs from the Carrion Crow which lives in pairs. Further differences are found in the feathering of the head and neck of these birds, that of the crow being much more completely covered than that of the rook. The croak of the crow is, moreover, much harsher than the caw of the rook. Like most, if not all other birds and animals, the rook serves a useful purpose in nature, in checking the multiplication of the worms and insects which prey upon the crops; and doubtless were he able to argue the question he would contend that helping the farmer to produce his harvest he has a right to a share in it. It is only when the rook in his turn gets too numerous that he needs a similar check.

The Carrion The Carrion Crow resembles the raven in apCrow. pearance, but is about one third smaller in size. It lives in pairs and is said to be a model of conjugal fidelity and parental care. Omnivorous in habit it appropriates all kinds of food: insects, grain, eggs, fruit, nuts, mice, ducklings and chickens, as well as such dead meat as may offer oppor- 
tunity. Captain Brown quoting from a Scotch newspaper tells of a crow which made an attempt to carry off one of a brood of fourteen chickens, but which on being disturbed, dropped its prey and made its escape, returning some time after with thirteen other crows and carrying off the whole brood.

The Jackdaw. The Jackdaw, measures about fourteen inches, and is thus the smallest of the birds of its kind. It builds in old ruins, church towers, and rocky eminences, in which particular it differs from the rooks and the crows, who select the topmost branches of trees for this purpose. Like its near relatives with whom we have been dealing, it is thievish and secretive in its habits, showing a preference, in its appropriations, for bright objects such as silver spoons and gold rings. These habits and their terrible consequences have been immortalized by the history and fate of the "Jackdaw of Rheims."

The Chough. The Chough frequents the western sea coasts of England, the north, south, and west of Ireland and the Isle of Man, and the borders of the snow line or Alpine ranges on the continent of Europe. It nests in the cavities of high cliffs and attains a length of seventeen inches; its beak and legs are of a brilliant red. When tamed it shows the same qualities of curiosity and secretiveness which characterise the other birds of its kind.

The

The Bird of Paradise is one of the most beautiful

Bird of. of living birds. Mr. Wallace thus describes the

Paradise. Paradisea apoda which is the largest species known: "The body, wings, and tail are of a rich coffee brown, which deepens on the breast to a blackish-violet or purple brown. The whole top of the head and neck is of an exceedingly delicate straw-yellow, the feathers being short and close set, so as to resemble plush or velvet; the lower part of the throat up to the eye is clothed with scaly feathers of an emerald green colour, and with a rich metallic gloss, and velvety plumes of a still deeper green, extend in 
a band across the forehead and chin as far as the eye, which is bright yellow. The beak is pale lead blue, and the feet which are rather large and very strong and well formed, are a pale ashy pink. The two middle feathers of the tail have no webs, except a very small one at the base and at the extreme tip, forming wire-like cirri, which spread out in an elegant double curve, and vary from twenty-four to thirty-four inches long. From each side of the body beneath the wings, springs a dense tuft of long and delicate plumes, sometimes two feet in length, of the most intense golden orange colour, and very glossy, but changing towards the tips into a pale brown. This tuft of plumage can be elevated and spread out at pleasure so as almost to conceal the body of the bird. These splendid ornaments are entirely confined to the male sex; the female is a very plain and ordinary looking bird. The male is generally seventeen or eighteen inches from the beak to the tip of the tail."

Hunting the

Bird of

Paradise.

In catching the Bird of Paradise, the natives take advantage of the apparent vanity of their victims. "In May when they are in full plumage," says Mr. Wallace, "the males assemble early in the morning to exhibit themselves in a most singular manner. This habit enables the natives to obtain specimens with comparative ease. As soon as they find that the birds have fixed upon a tree upon which to assemble, they build a little shelter of palm leaves in a convenient place among the branches, and the hunter ensconces himself in it before daylight, armed with his bow and a number of arrows terminating in a round nob. A boy waits at the foot of the tree, and when the birds come at sunrise, and a sufficient number have assembled, and have begun to dance, the hunter shoots with his blunt arrow so strongly as to stun the bird, which drops down, and is secured and killed by the boy, without its plumage being injured by a drop of blood. The rest take no notice, and fall one after another till some of 
them take the alarm." The Bird of Paradise is found in New Guinea and the Papuan Islands.

The Following Mr. Wallace's order we come now

Tanagers. to the second class of the perching birds, the Tanagroid perchers, with the more important species of which we will now proceed to deal.

The Tanagers are found in America and the West

Trnager. Indian Islands. Wilson, the American ornithologist, describing the scarlet Tanager, says: "Among all other birds that inhabit our woods, there is none that strikes the eye of the stranger or even a native with so much brilliancy as this. Seen among the green leaves, with the light falling strongly on his plumage, he really appears beautiful. If he has little melody in his notes to charm us, he has nothing in them to disgust. His manners are modest, easy and inoffensive; he commits no depredations on the property of the husbandman, but rather benefits him by the daily destruction in spring of many noxious insects; and when winter approaches he is no plundering dependant, but seeks in a distant country for that sustenance which the severity of the season denies to his industry in this. $\mathrm{He}$ is a striking ornament to our rural scenery and none of the meanest of our rural songsters." Its body is scarlet and its wings and tail are black. One species of the Tanager is known as the Organist Tanager from the richness of its tones.

The swallow. Though only a summer friend the swallow is among the most popular of birds in England. It arrives in April and is always sure of a hearty welcome, and when it leaves in September for its long journey across the sea no one would withhold from it a "God speed". The swallow builds under the eaves of houses, always selecting dry and sheltered spots. Its flight is very rapid, and is a pretty sight to watch as it skims over the surface of the water, sometimes striking it with its wings as it darts hither and thither, snapping at the flies and insects which come within its reach. The 
marvellous flights of these birds when they migrate are among the many wonderful things of nature. Humboldt states that he saw a swallow alight on the rigging of his vessel when it was one hundred and twenty miles from land. How such tiny creatures can sustain such extended flights it is difficult to understand.

Swallows in Swallows seem to understand the principle of Council. co-operation and what the family is unable to do for itself the community seems always ready to undertake for it. Captain Brown tells of a pair of swallows who returning to their last year's nest found it occupied by a robust English sparrow. The sparrow declined to give up the nest and the swallows were not strong enough to eject it, whereupon a council was called, as a result of which a large army of swallows proceeded to close up the entrance to the nest with clay, "leaving the sparrow to perish in the garrison it had so gallantly defended." This happened at Strathendry, Bleachfield, in Fifeshire, on the banks of the Leven, and was witnessed by Mr. Gavan Inglis. But not only do the swallows cooperate for the purposes of war; Mr. Inglis was a witness of another effort of combination. It happened that a pair of swallows had built a nest in the corner of one of his windows, in which they had hatched five oftspring. The parent birds fell victims to a sportsman's gun and Mr. Inglis contemplated an attempt to rear the family himself. This, however, proved unnecessary. In a very short time a number of swallows came and inspected the bereaved dwelling, apparently noting the condition of the house as well as the brood. A supply of food was immediately brought, and the next morning the kindly offices were renewed and thenceforward continued until the young were able to provide for themselves. Remarkable as these incidents are they are not singular, for both have been known to occur more than once.

The House The House Martin is characterized by a white Martin. spot above his tail which adds to the prettiness 
of his appearance in flight. The summer residence of this agreeable bird is universally among the habitations of man, who, having no interest in its destruction, and deriving considerable advantage as well as amusement from its company, is generally its friend and protector.

The Martin inhabits America as well as Europe, and is a particular favourite wherever it takes up his abode. "I never knew but one man," says Wilson, "who disliked the Martins, and would not permit them to settle about his house: this was a penurious, close-fisted German, who hated them, because, as he said, 'they eat his peas.' I told him he certainly must be mistaken, as I never knew an instance of Martins eating peas; but he replied with coolness, 'that he had many times seen them himself blaying near the hive, and going schnip schnap,' by which I understood that it was his bees that were the sufferers; and the charge could not be denied."

The sand The Sand Martin is the smallest of the British Martin. swallows and it is the first to arrive. It bores horizontal holes two or three feet deep into the sides of sand-pits, at the end of which it builds its nest of grass and feathers.

The Ohaffinch. The Finches are beautiful and interesting The Goldfinch. birds. The Chaffinch is famous for the vivacity The Greenflnoh. of its song and the beauty of its nest. "The forks of a thorn, or wild crab tree," says Mr. Wood, "are favourite places for the nest, which is composed of mosses, hair, wool and feathers, covered on the exterior with lichens and mosses so exactly resembling the bough on which the nest is placed that the eye is often deceived by its appearance." The Goldfinch is a favourite pet, and is capable of being trained to perform tricks. It has been called the Thistlefinch from its use of the down of the thistle in the construction of its nest. It is bright of appearance, cheery of song, and affectionate of disposition. The Greenfinch has a coat of rich olive green, and a waistcoat of greyish-yellow. 
The Iinnet. The Linnet is a homely looking little brown bird with a sweet melodious voice. It frequents commons and waste lands, where it builds its nest under the cover of friendly furze bushes, or nearer the habitations of man, in thick-set hedges. The Linnet is the natural laureate of the English cottage home.

The

The Canary, as its name implies, comes from

Canary. the Canary Islands, but it has been so crossed in breeding that it differs very considerably from its original ancestors. Buffon says:- "If the nightingale is the chauntress of the woods, the canary is the musician of the chamber; the first owes all to nature, the second something to art. With less strength of organ, less compass of voice, and less variety of note, the canary has a better ear, greater facility of imitation, and a more retentive memory; and as the difference of genius, especially among the lower animals, depends in a great measure on the perfection of their senses, the canary, whose organ of hearing is more susceptible of receiving foreign impressions, becomes more social, tame, and familiar; is capable of gratitude and even attachment; its caresses are endearing, its little humours innocent, and its anger neither hurts nor offends. Its education is easy; we hear it with pleasure, because we are able to instruct it. It leaves the melody of its own natural note, to listen to the melody of our voices and instruments. It applauds, it accompanies us, and repays the pleasure it receives with interest; while the nightingale, more proud of its talent, seems desirous of preserving it in all its purity, at least it appears to attach very little value to ours and it is with great difficulty it can be taught any of our airs. The canary can speak and whistle; the nightingale despises our words, as well as our airs, and never fails to return to its own wild-wood notes. Its pipe is a masterpiece of nature, which human art can neither alter nor improve; while that of the canary 'is a model of more pliant materials, which we can mould 
te No. 16
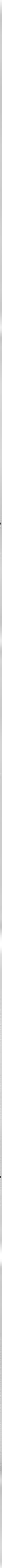
Digitized by Microsofte 
at pleasure; and therefore it contributes in a much greater degree to the comforts of society. It sings at all seasons, cheers us in the dullest weather, and adds to our happiness, by amusing the young, and delighting the recluse, charming the tediousness of the cloister, and gladdening the soul of the innocent and captive."

The Tame The canary is easily tamed, and has been taught

Canary. to perform many little tricks, indeed groups of them have been trained to act little plays, firing cannons and driving coaches. The canary shows a humane disposition, has been known to foster the young of other birds, to make friends with other pets, even cats; to show great affection for its master and to die of grief on the loss of its mate. Dr. Darwin tells of "a canary bird which always fainted away when its cage was cleaned. Having desired to see the experiment," says Dr. Darwin, "the cage was taken from the ceiling, and the bottom drawn out. The bird began to tremble, and turned quite white about the root of the bill; he then opened his mouth as if for breath, and respired quickly; stood up straighter on his perch, hung his wing, spread his tail, closed his eyes, and appeared quite stiff for half an hour, till at length, with trembling and deep respirations, he came gradually to himself."

The

The Crossbill must be mentioned for the sake

Orossbill of the peculiarity indicated by its name. The points of the beak instead of being straight and meeting in a common point, "curve to the right and left and always in opposite directions." They therefore cross each other and present a unique appearance. It is found in the North of Europe, and in the great pine forests of Germany.

The

There are several kinds of Bunting; the Eng-

Bunting. lish Bunting common to wayside hedges, and familiar from its habit of flitting in front of the traveller, and the Snow Bunting of the northern regions, which turns white on the approach of snow. 
The We come now to the third division of the starlings. Passeres or perching birds, to which Mr. Wallace attaches the name of the starlings. "The starlings or Sturnide," says Dr. Percival Wright, "are a well marked old-world group. No species of the family are found in Australia."

The The Common Starling is a bird of passage, Common arriving in England about the beginning of March

Btarling. and leaving some time in October. Knapp says:"There is something singularly curious and mysterious in the conduct of these birds previously to their nightly retirement, by the variety and intricacy of the evolutions they execute at that time. They will form themselves, perhaps, into a triangle, then shoot into a long, pear-shaped figure, expand like a sheet, wheel into a ball, as Pliny observes, each individual striving to get into the centre, etc., with a promptitude more like parade movements than the actions of birds. As the breeding season advances, these prodigious fights divide, and finally separate into pairs, and form their summer settlements." The Starling is a handsome bird and usually nests in old buildings, though it has a preference for a dove-cote if it can gain admission. It is a peaceable bird and for all its military evolutions does not seem to war with other species. Its domestic character is also good.

The Weaver The Weaver birds which are included in this

Bird. division, are a very interesting species. They belong to Africa, where they hang their nests upon trees, those of the sociable weaver birds giving the trees the appearance of partially thatched wall-less structures. Le Vaillant thus describes his experience of the sociable weaver bird: he says:- "I observed, on the way, a tree with an enormous nest of these birds, to which I have given the appellation of republicans; and as soon as I arrived at my camp, I dispatched a few men with a wagon to bring it to me, that I might open the hive and examine its structure in its minutest parts. When it arrived, I cut it to pieces with a hatchet 
and saw that the chief portion of the structure consisted of a mass of Buckmans grass, without any mixture, but so compactly and firmly basketed together, as to be impenetrable to the rain. This is the commencement of the structure; and each bird builds its particular nest under this canopy, the upper surface remaining - void without, however, being useless; for, as it has a projecting rim and is a little inclined, it serves to let the rain water run off and preserve each little dwelling from the rain. Figure to yourself a huge, irregular, sloping roof, all the eaves of which are completely covered with nests crowded one against another, and you will have a tolerably accurate idea of these singular edifices. Each individual nest is three or four inches in diameter, which is sufficient for the bird. But as they are all in contact with one another around the eaves, they appear to the eye to form one building and are distinguishable from each other only by a little external aperture which serves as an entrance to the nest; and even this is sometimes common to three different nests, one of which is situated at the bottom and the other two at the sides." One of these structures examined by Patterson contained three hundred and twenty inhabited cells.

The Irark. The skylark is common all over Europe and is an especial favourite in the British Isles. It builds its nest on the ground among growing corm or high grass, and shows especial care for its young. Its song is perhaps the most joyous and inspiriting of those of English birds. Captain Brown quotes the following interesting particulars of its song from a communication made by Mr. J. Main to the "Magazine of Natural History:" "His joyous matins and heavenward flight have been aptly compared to hymns and acts of adoration and praise. No bird sings with more method: there is an overture performed vivace crescendo, while the singer ascends; when at the full height, the song becomes moderato, and distinctly divided into short passages, each repeated three or 
four times over, like a fantasia, in the same key and time. If there be any wind, he rises perpendicularly by bounds, and afterwards poises himself with breast opposed to it. If calm, he ascends in spiral circles; in horizontal circles during the principal part of his song, and zigzagly downwards during the performance of the finale. Sometimes, after descending about half way, he ceases to sing, and drops with the velocity of an arrow to the ground. Those acquainted with the song of the skylark can tell without looking at them whether the birds be ascending or stationary in the air, or on their descent; so different is the style of the song in each case. In the first, there is an expression of ardent impatience; in the second, an andante composure, in which rests of a bar at a time frequently occur; and in the last, a graduated sinking of the strains."

The

Mrs. Bowdich quoting from "The Naturalist" Maternal gives the following pretty story of the maternal Instinct of instinct of the Lark:- "The other day, some the Lark. mowers shaved off the upper part of the nest of a skylark, without injuring the female, who was sitting on her young: still she did not fly away; and the mowers levelled the grass all round her, without her taking any notice of their proceedings. The son of the owner of the crop witnessed this, and, about an hour afterwards, went to see if she were safe; when, to his great surprise, he found that she had actually constructed a dome of dry grass over the nest during the interval, leaving an aperture on one side for ingress and egress; thus endeavouring to secure a continuance of the shelter previously supplied by the long grass." Buffon tells a remarkable story of the self-sacrifice of a young lark who took upon itself the duties of a foster mother. $\mathrm{He}$ says:- "A young hen bird was brought to me in the month of May, which was not able, to feed without assistance. I caused her to be educated, and she was hardly fledged when I received from another place a nest of three or four unfledged 
skylarks. She took a strong liking to these new-comers, which were scarcely younger than herself; she tended them night and day, cherished them beneath her wings, and fed them with her bill. Nothing could interrupt her tender offices. If the young ones were torn from her, she flew to them as soon as she was liberated, and would not think of effecting her own escape, which she might have done a hundred times. Her affection grew upon her; she neglected food and drink; she now required the same support as her adopted offspring, and expired at last consumed with maternal anxiety. None of the young ones survived her. They died one after another; so essential were her cares, which were equally tender and judicious."

The Lark The Lark when pursued by the Hawk has and the been known to seek refuge under the protection Hawk. of man, as the following quoted by Captain Brown from Bell's "Weekly Messenger" will show. "On Wednesday, the 6th of October, 1805, as a gentleman was sitting on the rocks at the end of Collercot's sands, near Tynemouth, Northumberland, dressing himself after bathing, he perceived a hawk in the air, in close pursuit of, and nearly within reach of a lark. To save the little fugitive, he shouted and clapped his hands, when immediately the lark descended, and alighted on his knee, nor did it offer to leave him, when taken into the hand, but seemed confident of that protection, which it found. The hawk sailed about for some time. The gentleman, after taking the lark nearly to Tynemouth, restored it to its former liberty."

The Wagtails The Wagtails, of which family the Pied Wagand Pipits. tail is the most familiar, derives its name from its habit of wagging its tail. As Mr. Wood says, "it settles on the ground and wags its tail; it runs a few paces and wags its tail again; pecks an insect, and again its tail vibrates." It frequents sandbanks and the margins of rivers where it finds its food. It is found in England throughout the year, 
migrating to the southern counties in the early winter. The Pipits, of which "The Meadow Pipit" and the Tree Pipit are the best known varieties, are found all over the British Isles as well as in many parts of Europe.

The Ant- The fourth division of the perching birds desigIraters. nated by Mr. Wallace, the Ant-Eaters, includes a large number of American varieties, which space forbids us even to enumerate. One or two must suffice.

The King The King Bird or Tyrant Fly-catcher of North Bird. America is small, but of a fearless disposition, attacking hawks, crows, and other larger birds, and generally having the best of the battle. The upper part of its body is black and the lower of a delicate white. Its song is a shrill twittering "resembling the jingling of a bunch of keys." It belongs to the family of the Tyrant Shrikes or Tyrannida. It is during the time of incubation that it shows so much ferocity. Wilson says, "I have seen the red-headed woodpecker while clinging on a rail of the fence, amuse himself with the violence of the king bird, and play 'bo-peep' with him round the rail, while the latter, highly irritated, made every attempt, as he swept from side to side, to strike him, but in vain. All his turbulence subsides as soon as his young are able to shift for themselves, and he is then as mild and peaceable as any other bird."

The The Chatterers, or Cotingidae include among Chatterers. them, the Cock of the Rock, one of the most beautiful of South-American birds. Resembling a pigeon in size, its head is sufficiently like that of the farm-yard cock to account for its name, which is also made to indicate the nature of its haunts. Its coat is a warm saffron yellow and its crest resembles a fan. Sir Robert Schomburgh says: "While traversing the Kikiritze mountains in Guiana, we saw a number of that most beautiful bird, the cock-of-therock, or Rock Manakin (rupicola elegans), and I had an opportunity of witnessing an exhibition of some of its very 
singular antics, of which I had heard stories from the Indians, but had hitherto disbelieved them. Hearing the twittering noise so peculiar to the Rupicola, I cautiously stole near, with two of my guides, towards a spot secluded from the path from four to five feet in diameter, and which appeared to have been cleared of every blade of grass, and smoothed as by human hands. There we saw a cock-of-the-rock, capering to the apparent delight of several others, now spreading its wings, throwing up its head, or opening its tail like a fan; now strutting about, and scratching the ground, all accompanied by a hopping gait, until tired, when it gabbled some kind of note, and another relieved it. Thus three of them successively took the field, and then with self-approbation withdrew to rest on one of the low branches near the scene of action. We had counted ten cocks and two hens of the party, when the crackling of some wood, on which I had unfortunately placed my foot, alarmed and dispersed this dancing party." The Bell Bird of Brazil; the Umbrella Bird of the Amazons, the Broadbills, the Plant cutters, the Oven bird, and the Ant-Thrushes are all included in this group.

The Iyre The Lyre Bird, which according to the classifiBird. cation we are following, with the scrub bird, forms the fifth group of the perching birds, belongs to Australia. The Lyre Bird has been so often depicted in illustrations that its form is familiar to most people. The tail of the male bird which is composed of three different kinds of feathers so beautifully resembles the Lyre that there could be no hesitation in giving the bird its name. Since its discovery this bird has been so hunted as to considerably reduce its numbers, and the tail feathers which at one time could be purchased at a low price, have become rare and costly.

ORDER II. This order includes some widely different speClimbers and cies and is made up of Scansores, Climbers and Gapers. Fissirostres, Gapers. A few of the better known species are all that we can mention. 
The Wood- The green Woodpecker is the variety best pecker. known in England, where it inhabits the woods and feeds upon the insects it finds in the bark of trees. Audubon writing of the "Ivory-billed" variety says:- "The birds pay great regard to the particular situation of the tree, and the inclination of its trunk; first, because they prefer retirement, and again, because they are anxious to secure the aperture against the access of water during beating rains. To prevent such a calamity the hole is generally dug immediately under the junction of a large branch with the trunk. It is first bored horizontally for a few inches, then directly downwards, and not in a spiral manner as some people have imagined. According to circumstances, this cavity is more or less deep, being sometimes more than ten inches, whilst at other times it reaches three feet downwards into the core of the tree. The average diameter of the different nests which I have examined was about seven inches within, although the entrance, which is perfectly round, is only just large enough to admit the bird." Wilson declares that during the excavation of its nest, which occupies several days, the woodpecker will often carry the chips and strew them at distance to divert suspicion. Audubon describing the Red-headed Woodpecker says:- "With the exception of the mocking bird, I know no species so gay and frolicsome. Their whole life is one of pleasure."

The This bird which was known to the Greeks, and Wryneck. described by Aristotle, forms with its allied species a connecting link between the Woodpecker and the Cuckoo. It feeds on caterpillars and insects which it catches with its long sticky tongue, with such rapidity of movement that the eye cannot follow it.

The Cuckoo. The Cuckoo is always welcomed in England as the harbinger of Spring. Its cry is one of the most easily distinguished of bind songs, and is the nearest approach to a definite musical interval produced by any bird. The habit 
of the cuckoo of laying its eggs in the nests of other birds, has given rise to much speculation, ancient and modern, and now, though the fact remains, a sufficiently satisfactory reason seems as remote as ever. The nest of the Hedgesparrow seems to be the one most often selected, though that of the wagtail is sometimes chosen. The consequences to the young of the native bird, are somewhat serious as the following will show.

The Cuckoo

and the

Hedge-Sparro

Dr. Jenner, the discoverer of vaccination says:- "On the 18th of June, 1787 , I exammodularis), which then contained a cuckoo and three hedgesparrows' eggs. On inspecting it the day following, the birt had hatched; but the nest then contained only a young cuckoo and one hedge-sparrow. The nest was placed so near the extremity of a hedge, that I could distinctly see what was going forward in it; and, to my great astonishment, I saw the young cuckoo, though so lately hatched, in the act of turning out the young hedge-sparrow. The mode of accomplishing this was very curious; the little animal, with the assistance of its rump and wings, contrived to get the bird upon its back, and making a lodgment for its burthen by elevating its elbows, clambered backwards with it up the side of the nest till it reacked the top, where, resting for a moment, it threw off its load with a jerk, and quite disengaged it from the nest. It remained in this situation for a short time, feeling about with the extremities of its wings, as if to be convinced whether the business was properly executed, and then dropped into the nest again. I afterwards put in an egg, and this, by a similar process, was conveyed to the edge of the nest and thrown out. These experiments I have since repeated several times, in different nests, and have always found the young cuckoo disposed to act in the same manner. "It sometimes happens that two cuckoos' eggs are deposited in the same nest, and then the young produced from one of 
them must inevitably perish. Two cuckoos and one hedgesparrow were hatched in the same nest, and one hedgesparrow's egg remained unhatched. In a few hours afterwards a contest began between the cuckoos for the possession of the nest, which continued undetermined till the next afternoon, when one of them, which was somewhat superior in size, turned out the other, together with the young hedge-sparrow and the unhatched egg. The combatants alternately appeared to have the advantage, as each carried the other several times to the top of the nest, and then sunk down again, oppressed by the weight of the burthen; till at length, after various efforts, the strongest prevailed, and was afterwards brought up by the hedge-sparrow." Jenner's experiences have been corroborated by repeated experiments since. Colonel Montague carried a hedge-sparrow's nest, so inhabited, into his house where he could watch it at leisure and where he saw the young cuckoo frequently oust the baby hedge-sparrow in the manner described. The cuckoo feeds on caterpillars, and insects. It may be tamed, but as a rule does not live long in confinement. Its note is heard from April to June.

The

That the cuckoo is scarcely an amiable bird Cuckoo and the Thrush. would appear from the following incident recorded by Dr. Stanley: "A young thrush, just able to feed itself, was placed in a cage. A short time after, a young cuckoo, which could not feed itself, was placed in the same cage, and fed by the owner. At length it was observed that the thrush fed it; the cuckoo opening its mouth, and sitting on the upper perch, and making the thrush hop down to fetch its food. One day, while thus expecting its supply, a worm was put into the cage, and the thrush could not resist the temptation of eating it, upon which the cuckoo descended, attacked the thrush with fury, and literally tore out one of its eyes, and then hopped back. Although so lacerated, the poor thrush meekly took up some food, and continued to do so till the cuckoo was full grown." 
Digitized by Microsofte 
The The Trogons are among the most gorgeous of Trogons. living birds; the brilliance of their plumage defying verbal description. Their main colour is "a metallic golden green, boldly contrasted with scarlet, black, and brown." "The Resplendent Trogon," says Mr. Wood, "is the most gorgeous of all this gorgeous family. Its long and gracefully curved tail is nearly three feet long, and the whole of the upper surface, and the throat, are a glowing green; the breast and under parts are bright crimson; the middle feathers of the tail black, and the outer feathers white." These birds are natives of Mexico.

The The Kingfishers are a wide-spread family, being Kingtisher. found all over the world. There are numerous . varieties, of which the Common Kingfisher and the Laughing Kingfisher are all that we can notice. The Common Kingfisher is indigenous in England where it usually lives on the banks of rivers and streams, feeding upon fish and insects. It makes burrows or holes in the banks, where it lays its eggs and rears its young; fishing from the low branches of trees which overspread the water. When the fish is caught it is beaten to death against some hard substance and then swallowed whole, head foremost. The Common Kingfisher is somewhat larger than the lark, and has a beautiful metallic coat which shimmers with a very pleasing effect as it darts among the greenery of the river bank or flies along the surface of the water. The Laughing Kingfisher belongs to Australia and is so named from its peculiar cry. It is one of the largest species of its kind. Other species belong to the Moluccas and New Guinea, and a few to America.

The The Hornbill is famous for the size and shape Hornbill. of its bill, which is very large. There are several varieties, African and Indian. They live mostly on fruit, though some are said to eat reptiles. They have some very curious habits. Mr. Wallace describes the habit of the male Hombill of shutting up the female during the period of 
incubation and feeding her through a small hole left open for the purpose.

The Goat- The goat-sucker is so called from the belief

suckers. long entertained that it was in the habit of sucking the teat of the goat. There are several varieties and they are remarkable for the strangeness of their cries. The Goat-sucker has sometimes been called the Night-jar from its discordant note, it is also known as the Fern Owl. Mr. Wood says:- "It may be seen at the approach of evening silently wheeling round the trees, capturing the nocturnal moths and beetles; then occasionally settling and uttering its jarring cry. When flying the bird sometimes makes its wings meet over its back, .and brings them together with a smart snap. It arrives in England in the beginning of May and leaves in December. The Whip-poor-will and the Chuck-will's-widow both belong to this family."

The Whip- The Whip-poor-will, which is peculiar to America, poor-Will. is celebrated for its singular melody, which is heard in spring to issue at night from the woods and glens of all parts of the country. It is a rapid warbling repetition of the name given to the bird, and is so distinctly pronounced, as to seem like the voice of a human being. It is a solitary bird, remaining silent and sequestered during the day, but at night it often approaches a dwelling, and pours forth its song upon the door-step, or a neighbouring tree.

Chuck-Will's. This bird, also peculiar to America, is about

widow. a foot in length, resembling in colour, form, and habits, the whip-poor-will. It is a solitary bird, frequenting glens and hollows, and seldom making its appearance during the day. Its song, which is uttered, like that of the whippoor-will, at night, is a constant repetition of the sound, chuck-will's-widow, very distinctly articulated. It is common in Georgia, and is regarded by the Creek Indians with superstitious awe. It is very seldom seen in the Middle or Eastern States; "but I recollect once," says an American writer, "to have 
known a whole village in New England in terror and amazement at hearing one of them singing its strange song on the edge of a swamp. The superstitious part of the inhabitants considered it a prediction of some evil that was to befall a widow of the parish; but there was a diversity of opinion as to who the hapless Chuck-will's-widow might be."

The The Swift, so called from the remarkable speed

Bwift. of his flight, is also known as "Jack screamer" from the shrillness of his voice. He winters in Africa and arrives in England about May, remaining until about the middle of August. He builds his nest under the eaves of houses and frequents steeples and other lofty edifices, forming his nest of grasses and feathers. The esculent swift, so called from the fact that its nests are edible, builds at the sides of almost inaccessible cliffs, a habit which renders the collection of these singular dainties very dangerous. The nests are formed of mucilaginous sea-weeds and have the appearance of isinglass. They are considered great delicacies in China, where they are found. They abound in Java. The swifts resemble the swallows in several particulars and have often been classed with them, there are, however, important differences which separate them.

The Humming There are hundreds of kinds of Humming Birds,

Bird. nearly all of them natives of America, where they frequent the gardens, and sip the honey from the honeysuckle and other plants, like the hive and humble bee. The humming bird is several times larger than the latter, but flies so swiftly as almost to elude the sight. Its wings, when it is balancing over the flower, produce a humming sound, from which it takes its name. It is the smallest of the feathered race, and is one of the most beautiful in the elegance of its form, and the glossy 'brilliancy of its delicate plumage. Small as it is, however, it is exceedingly courageous, and has violent passions. The length of this bird is three inches; it lives partly on honey obtained from flowers, but devours also great quan- 
tities of very small insects. The general colour is a rich golden green on the upper parts; the breast and neck are of a dusky white. Its nest is very small, and is elegantly lined with the down of the mullein. It is covered on the outside with moss, to imitate the colour of the limb on which it is built.

ORDERIII. The parrots never fail to interest, on account The Parrots. of their beauty of form and colour, and their aptitude for imitating common sounds. There are some hundreds of species, belonging to different parts of the world, the Cockatoos to Australia, the Macaws to America, and many varieties to Africa. The Macaws and some other kinds are among the most gorgeous of living birds and whether seen in their native wilds or in the aviaries of civilisation never fail to excite admiration. The Cockatoo is distinguished from the true parrot by its crest; other species are differentiated by habit, size, colour, and form. The better known of these are, the Sulphur-crested Cockatoo, the Ground parrot, the Macaw, the Grey parrot, the Green parrot, the Parrakeets and the Love-birds.

The Parrot's Many stories are told of the remarkable powers Intelligence. of individual parrots and the singular appropriateness of their remarks on particular occasions. These are often so startling as to arouse suspicion of their authenticity, and yet a moment's reflection will show that coincidence plays a large part in these demonstrations, and that many of the most astonishing examples of felicitous interjection, or repartee, are due to this, and not to any special gift of intelligence on the part of the bird. An ordinary parrot with half a dozen phrases which it is constantly repeating, will in the nature of things, often use them in singularly felicitous connection with current conversation. No notice is taken of the many instances in which the phrase is inappropriate and yet a few cases of remarkable fitness are held to demonstrate extraordinary intelligence. Teach a parrot such a simple 
rejoinder as "not I!" and the bird using it in answer to all sorts of questions, will often use it with apparent intelligence, but a doll might be made to show equal wit. That parrots are taught to give certain answers to certain questions is of course true, but in these cases the questions suggest the answers and all the intelligence is shown by the interrogator. Those birds which have lived many years and acquired many phrases, will naturally, from the extent of their repertoire, the more often surprise their hearers; but that they show any greater intelligence may perhaps be doubted. That some of the parrots, and especially the Love-birds, show great feeling for each other and attachment to their owners is well known, but the claim sometimes made that they show greater intelligence than any other birds may be very safely disputed. The term "parrot-like," as applied to the repetition of lessons by rote which are not understood by those repeating them, involves no injustice to the parrot.

Famous There have been many famous parrots who

Parrots. have played their part in history if they have not rivalled the geese that saved Rome. The Emperor Basilius Macedo was induced by a Parrot, who cast a gloom over the guests at a banquet by continually calling out, "Alas, alas! poor Prince Leo", to liberate his son whom he had confined on suspicion of treason. The Emperor observed the gloom of his guests and urged them to the pleasures of the table, when one of them is said to have responded, "How should we eat, Sire, when we are thus reproached by this bird of our want of duty to your family? The brute animal is mindful of its Lord; and we that have reason, have neglected to supplicate your Majesty in behalf of the prince, whom we all believe to be innocent, and to suffer under calumny." Whether the bird had been purposely taught this phrase, or had merely acquired it by hearing its frequent repetition does not appear. The following memorial which appeared in the London papers in October 1822 is quoted from the "Percy 
Anecdotes." "A few days ago, died, in Half Moon Street, Piccadilly, the celebrated parrot of Colonel O'Kelly. This singular bird sang a number of songs in perfect time and tune. She could express her wants articulately, and give her orders in a manner nearly approaching to rationality. Her age was not known; it was, however, more than thirty years, for previous to that period, Colonel O'Kelly bought her at Bristol for one hundred guineas. The Colonel was repeatedly offered five hundred guineas a year for the bird, by persons who wished to make a public exhibition of her; but this, out of tenderness to the favourite, he constantly refused. She could not only repeat a great number of sentences, but answer questions put to her. When singing, she beat time with all the appearance of science; and so accurate was her judgment that if by chance she mistook a note, she would revert to the bar where the mistake was made, correct herself, and still beating regular time, go through the whole with, wonderful exactness." A Grey parrot is said to have been sold in I500, for a hundred guineas, to a Lord High Cardinal at Rome, on account of its ability to repeat, without error, the Apostles' Creed.

The Grey The Grey Parrot though less attractive in colour

Parrot. than other species, is perhaps the most popular of the parrot family on account of its superior accomplishments as an imitator of familiar sounds. Mr. Jesse secured from a lady friend a description of the performances of a grey parrot which resided at Hampton Court, from which we quote the following: "Her laugh is quite extraordinary, and it is impossible not to help joining in it, more especially when in the midst of it she cries out, 'Don't make me laugh so; I shall die, I shall die!' and then continues laughing more violently than before. Her crying and sobbing are curious; and if you say, 'Poor Poll, what is the matter?' she says, 'So bad, so bad; got such a cold;' and after crying some time, will gradually cease, and making 
a noise like drawing a long breath, say, 'Better now' and begins to laugh." "If any one happens to cough or sneeze, she says, 'what a bad cold.' She calls the cat very plainly, saying, 'puss, puss,' and then answers 'mew'; but the most amusing part is, that whenever I want to make her call it, and to that purpose say, 'puss, puss', myself she always answers, 'mew', till I begin mewing; and then she begins calling 'puss', as quickly as possible. She imitates every kind of noise, and barks so naturally, that $I$ have known her to set all the dogs on the parade of Hampton Court barking, and the consternation I have seen her cause in a party of cocks and hens, by her crowing and chuckling, has been the most ludicrous thing possible. She sings just like a child and I have more than once thought it was a human being; and it is most ludicrous to hear her make what one would call a false note and then say, 'oh la!' and burst out laughing at herself, beginning again in quite another key. She is very fond of singing 'Buy a Broom', which she says quite plainly, but if we say, with a view to make her repeat it, 'Buy a Broom', she always says 'Buy a Brush', and then laughs as a child might do when mischievous. She often performs a kind of exercise which I do not know how to describe, except by saying that it is like the lance exercise. She puts her claw behind her, first on one side and then on the other, then in front, and round over her head; and whilst doing so, keeps saying, 'Come on, come on!' and when finished she says 'Bravo, beautiful,' and draws herself up."

Parrot To deny the parrot the understanding of what

Talk. it says, is to relieve it of the responsibility of using bad language, and offering unsound advice, and this it surely needs. A gentleman who was in the habit of kissing his parrot and then kissing his wife, before leaving home in the morning, taught the bird to say, on being kissed, "Now kiss the missus," with the result that most of the gentlemen visitors who took any notice of the parrot were 
recommended to salute the lady of the house. Another parrot whose cage occupied a window close to a fashionable church continually accosted the passers-by, by calling out "That's right! Go to church, keep up appearances." Such remarks must often be very embarrassing, as must have been the words and actions of a parrot who frequently called out "Who kissed the pretty girl?" and then gave a perfect imitation of the sound of several kisses in succession. Perhaps no more aggravating use was ever made of a parrot's powers than that witnessed by Buffon, who says, "I have seen a parrot very ridiculously employed, belonging to a distiller who had suffered pretty severely in his circumstances from an informer who lived opposite him. This bird was taught to pronounce the ninth commandment, - 'Thou shalt not bear false witness against thy neighbour,' with a very clear, loud, articulate voice. The bird was generally placed in a cage over against the informer's house, and delighted the whole neighbourhood with its persevering exhortations." ORDER IV. There are many varieties of pigeons, some Pigeons, being peculiar to certain districts, and others covering a much more extended geographical area. Mr. Darwin divides the British varieties into four groups: I. The English carrier; the Runt, and the Barb. II. The Fantail; the African owl; the Short-faced Tumbler; the Indian Frillback; and the Jacobin. III. The English Pouter, and IV. The Dove-cote pigeon; the Swallow; the Spot; the Nun; the English Frill-back; the Laugher, and the Trumpeter. The Passenger pigeon of America, the Nicobar pigeon of the Philippine Islands, the Great-crowned pigeon of New Guinea and the Hook-billed ground pigeon of Samoa are other important species.

Carrier In the "Percy Anecdotes" there is a brief history

Pigeons. of the use of carrier pigeons, which we quote as follows :- "The first mention we find made of the employment of pigeons as letter carriers is by Ovid, in his 'Metamor- 
phoses', who tells us that Taurosthenes, by a pigeon stained with purple, gave notice of his having been victor at the Olympic games on the very same day to his father at Egina. Pliny informs us that during the siege of Modena by Marc Antony, pigeons were employed by Brutus to keep up a correspondence with the besieged. When the city of Ptolemais, in Syria, was invested by the French and Venetians, and it was ready to fall into their hands, they observed a pigeon flying over them, and immediately conjectured that it was charged with letters to the garrison. On this, the whole army raising a loud shout, so confounded the poor aërial post that it fell to the ground, and on being seized, a letter was found under its wings, from the sultan, in which he assured the garrison that 'he would be with them in three days, with an army sufficient to raise the siege.' For this letter the besiegers substituted another to this purpose, "that the garrison must see to their own safety, for the sultan had such other affairs pressing him that it was impossible for him to come to their succour;' and with this false intelligence they let the pigeon free to pursue his course. The garrison, deprived by this decree of all hope of relief, immediately surrendered. The sultan appeared on the third day, as promised, with a powerful army, and was not a little mortified to find the city already in the hands of the Christians. Carrier pigeons were again employed, but with better success, at the siege of Leyden, in 1675. The garrison were, by means of the information thus conveyed to them, induced to stand out, till the enemy, despairing of reducing the place, withdrew. On the siege being raised, the Prince of Orange ordered that the pigeons who had rendered such essential service should be maintained at the public expense, and that at their death they should be embalmed and preserved in the town house, as a perpetual token of gratitude."

Pigeons on Pigeons are said to travel as fast as 2,200 yards the Wing. per minute and to sustain flight for hundreds of 
miles at a stretch. The extraordinary manner in which they will find their way almost incredible distances has suggested all kinds of speculation as to the instinct or sense which guides them. A well known pigeon fancier, interviewed by a writer who published the results of the interview in "Chums" (Cassell \& Co.) says, "The popular notion that carrier pigeons are guided by some 'direction sense,' or blind instinct, is quite as absurd as the French belief that they follow certain electrical currents. I have had to do with pigeons for over twenty years," he continued, "and I am open to demonstrate to anyone that in flight they are guided by sight alone. Of course, some pigeons are more sagacious, cleverer than others; but the fact remains, and everything tends to prove it. For example, no carrier-pigeon can find its way over a strange country: it often gets lost in a fog; and again, until taught by experience, it is often led astray by colours and objects which appear to be familiar. Quite recently, when I was trying some young birds, I had an instance of how easily they may be led astray. Close to my residence is a large red-brick building, which, to an old bird, would prove a good landmark miles away. In this case, however, the birds had not been tried before, although, of course, they had been let loose and had circled round the loft for several weeks. I took five birds with me some half-mile distant from home; and, letting them loose separately from the box, was rather surprised to see four out of the five, after circling round, fly off in an entirely opposite direction to that in which they should have gone. I soon solved the mystery, however, for, watching the birds, I saw they were making for another red-brick building, which showed up clearly in the sunlight. Arriving there, each one evidently discovered its mistake, and, after flying back to the starting-point, found their whereabouts, and made for home-not in a straight line, however, for young birds invariably take a crooked, tortuous path, as though feeling their way. If pigeons are let loose on water 
(from a boat in a lake or wide river), they always make for the nearest land first; then, circling round, widening their circle and rising higher at the same time, they keep the starting-point in view until they sight some familiar object, in which direction they travel. If a bird is dull, or 'stupid,' as we term it, and has been tried from various points of the compass, it often happens that, when taken to a distance (say thirty or forty miles), the time occupied in reaching the loft is three of four times longer than was expected; but, take it there next day, and the journey will be done quicker than a mile a minute. Why is that? Well, the birds get confused; some object which it may have seen on a former journey, may possibly stand out boldly; and, flying at once toward this, the bird may find itself just as far from finding the 'lay of the land.' Thus it may go from one familiar point to another before 'striking' for home. That is the reason why, in training a bird for a match, we take it only in the direction from which it will have to fly, increase the distance gradually, until the bird is familiar with the path it must travel and recognises each landmark as soon as it comes in sight."

ORDER V. In this order (Galline) the Grouse, the PtarFowls. migan, the Quail, the Peacock, the Pheasant, the Jungle Fowl, the Guinea Fowl, and the Wild Turkey are included; as well as our Domestic Fowls to the forms of which they more or less closely approximate. The Black Grouse, and the Red Grouse are found throughout Great Britain; the Prairie Grouse in North America. The Ptarmigan is found in Scotland and in the North of the continent of Europe; it changes colour with the seasons, becoming snow-white in winter. The Quail is found in many parts of Europe, Asia, and Africa; it visits England in the early summer and leaves about October for Africa, where it winters.

The

The Peacock has been famous in the East from

Percock. before the days of Solomon and the Queen of 
Sheba, and has been much affected in England in more recent years, on account of its beauty, as an adornment of English lawns, and as a royal dainty upon the festive board. It may be said still to keep its place as an ornament of the park, but it is no longer the choice of the epicure and seldom appears at the feast. It is said to have come originally from Persia and has doubtless reached the west from India where it still abounds. Colonel Williamson says that he has seen, in the passes of the Jungletery district, as many as twelve or fifteen hundred pea-fowls of various sizes within sight of one spot. "The gorgeous plumes that adorn the Peacock," says Mr. Wood, "do not compose the tail, as many suppose, but are only the tail-coverts. The tail feathers themselves are short and rigid, and serve to keep the train spread, as may be seen when the bird walks about in all the majesty of his expanded plumage. Although pea-fowl seek their food on the ground, they invariably roost on some elevated situation, such as a high branch, or the roof of a barn or haystack." The peacock is swift of foot, but heavy on the wing, and remains ordinarily on the ground, where it finds its food. It has a harsh voice. The peahen is a plain, homely looking bird, lacking the gorgeous tail which adorns her lord and master. Guillim, an old writer quoted by Captain Brown, says: "The Peacock is so proud, that when he erecteth his fan of plumes, he admireth himself. He displayeth his plumes against the rays of the sun, that they may glister the more gloriously: and he loseth this beautiful train yearly with the fall of the leaf; at which time he becometh bashful, and seeketh corners, where he may be secret from the sight of men, until the spring of the year, when his train beginneth to be renewed. And such is the quality of many dames, who being painted and richly attired, cannot keep within doors; but being undressed, and in their own hue, they are loath any man should see them."

The

There are several varieties of the Pheasant, of Phemsant. which the Peacock Pheasant of Burmah, the 
Argus Pheasant of Malacca, the Golden Pheasant of China, and the Common Pheasant are the better known species. The Common Pheasant is a native of the British Isles, where it is cultivated and preserved. Under some circumstances the cock pheasant displays considerable pugnacity and a story is told of a young lady who when walking near Stirling was attacked by one which, "with spurs and beak began a furious assault. Seeing no escape from the enraged bird, she seized her adversary, and carried him home. He was, however, soon released, and when the door was opened, he went out without any sign of fear, and, with a deliberate step, paced backwards and forwards in front of the house, and manifested an inclination to join the fowls in the poultry yard. The only way to account for this assault is, that the lady wore a scarlet mantle, to which the pheasant may have " had such an antipathy as the turkey cock manifests to that colour; an antipathy evinced by many other birds, and various quadrupeds; and the cause of which is to us a mystery."

The

The partridge is an interesting bird and shows Partridge. great intelligence in the care of its young. Mr. Jesse mentions an instance quoted by Mr. Wood. "A gentleman who was overlooking his ploughman, saw a partridge run from her nest, almost crushed by the horses' hoofs. Being certain that the next furrow must bury the eggs and nest, he watched for the return of the plough, when to his great astonishment, the nest, previously containing twenty-one eggs, was vacant. After a search, he found the bird sitting upon the eggs under a hedge, nearly forty yards from the nest, to which place she and her mate had removed the whole number in less than twenty minutes." Mr. Markwick relates, that "as he was once hunting with a young pointer, the dog ran on a brood of very small partridges. The old bird cried, fluttered, and ran trembling along just before the dog's nose, till she had drawn him to a considerable distance; 
when she took wing and flew farther off, but not out of the field. On this the dog retumed nearly to the place where the young ones lay concealed in the grass; which the old bird no sooner perceived, than she flew back again, settled just before the dog's nose, and a second time acted the same part, rolling and tumbling about till she drew off his attention from the brood, and thus succeeded in preserving them."

The wild The Wild Turkey was at one time common in

Turkey. all parts of America, but it is fast diminishing, and is now seldom found except in the western territories. It is often larger than the domestic turkey; it is gregarious and feeds on grain, seeds, and fruits. It is the original stock of the domestic turkey. Mr. Lucien Bonaparte has given a long and interesting account of this bird. He says they sometimes fly across broad rivers, ascending the tallest trees on one side, and the whole flock starting together. Some of the younger and weaker birds sometimes fall into the water and either paddle to the shore or are drowned.

The Domestic The Wild Turkey was first carried to Europe

Turkey. and other parts of the eastern continent and domesticated in the r6th century. It is now extensively diffused over the world, and its flesh is ranked among the most delicious poultry. The cock is a noisy fellow, strutting about, and displaying his plumage with great ostentation; he is also very quarrelsome. The hen seems to possess a more modest and retiring disposition, wandering about the fields with a melancholy and dejected air, occasionally uttering a short plaintive note. She is exceedingly attached to her young, but leads them away from danger without ever attempting to defend them by repelling an attack.

The Sagacity of Of the sagacity of the Turkey Audubon

the Turkey. says: "While at Henderson, on the Ohio, I had a fine male turkey, which had been reared from its earliest youth under my care. It became so tame that it 
would follow any person who called it, and was the favourite of the little village. Yet it would never roost with the tame turkeys; but regularly betook itself at night to the roof of the house, where it remained till dawn. When two years old it began to fly to the woods, where it remained for a considerable part of the day, and returned to the enclosure as night approached. It continued this practice until the following spring, when I saw it several times fly from its roosting-place to the top of a high cotton-tree on the bank of the Ohio, from which, after resting a little, it would sail to the opposite shore, the river being there nearly half a mile wide, and return towards night. One morning I saw it fly off, at a very early hour, to the woods in another direction, and took no particular notice of the circumstance. Several days elapsed, but the bird did not return. I was going towards some lakes near Green River, to shoot, when, having walked about five miles, I saw a fine large gobbler cross the path before me, moving leisurely along. Turkeys being then in prime condition for the table, I ordered my dog to chase it and put it up. The animal went off with great rapidity, and as it approached the turkey, I saw, with great surprise, that the latter paid little attention. Juno was on the point of seizing it, when she suddenly stopped, and turned her head towards me. I hastened to them; but you may easily conceive my surprise when I saw my own favourite bird, and discovered that it had recognised the dog, and would not fly from it, although the sight of a strange dog would have caused it to run off at once. A friend of mine, being in search of a wounded deer, took the bird on his saddle before him, and carried it home for me. The following spring it was accidentally shot, having been taken for a wild bird, and brought to me, on being recognised by the red ribband which it had round its neck."

Bitting

The male Turkey is said to be but an indifferent Turkey Oooks. father, but there are some curious illustrations 
on record of his displaying maternal instincts. Captain Brown tells of a cock Turkey near Abingdon who manifested a desire to sit and was allowed to experiment with thirteen eggs, from which in three weeks he hatched twelve fine chickens. A precisely similar incident occurred many years ago in Sweden, according to the same authority.

Domestic The Domestic Fowls are too well known to need

Fowle. description here. They are said to have descended from the Java species and have long been the subjects of systematic and careful culture. John Guillim who wrote in 1677 and whose quaint description of the peacock we have already quoted, says: "As some account the eagle the queen, and the swallow or wagtail the lady, so may I term this (the cock) the knight amongst birds, being both of noble courage, and also prepared evermore to the battel, having his comb for an helmet, his sharp and hooked bill for a faulchion or court-lax, to slash and wound his enemy: and as a compleat soldier armed capa-pe, he hath his legs armed with spurs, giving example to the valiant soldier to expell danger by fight, and not by flight. The cock croweth when he is victor and giveth a testimony of his conquest. If he be vanquished, he shunneth the light, and society of men." The cock is a courageous bird and in fighting with his own kind or in the defence of his family will show great gallantry and endurance. Buffon thus describes an encounter of which he was an observer. He says: "I have just witnessed a curious scene. A sparrow hawk alighted in a populous court-yard; when a young cock, of this year's hatching, instantly darted at him, and threw him on his back. In this situation, the hawk defending himself with his talons and his bill, intimidated the hens and turkeys, which streamed tumultuously around him. After having a little recovered himself, he rose and was taking wing; when the cock rushed upon him a second time, upset him, and held him down so long, that he was easily caught by a person who witnessed the conflict." The cock is said to show many of the quali- 
ties which belong to knighthood. He is jealous, and has been known to kill a hen which has hatched a foreign brood; and he is chivalrous both in the treatment of his hens and in their defence against their enemies. He has a sense of justice too, which he does not hesitate to assert on occasion. Mrs. Bowdich says: "On one occasion I saw a cock pursue a hen round the poultry-yard; and, as she had a worm in her bill, I at first thought he was so acting from a greedy desire to have the delicious morsel; but when he at last caught her, he gave her a knock on the head with his beak, and, taking up the worm which she had dropped, brought it to another hen, who stood witnessing the affray in mute expectation. A further knowledge of the habits of these birds has made me feel sure she had purloined the worm from the other, and the cock had restored it to its rightful owner." Though natural fighters, cocks sometimes form friendships for each other, and Captain Brown records an instance of two game cocks, belonging to the same owner, who obstinately declined combat though all means were tried to excite mutual animosity. These same birds when placed in the ring with other cocks fought furiously, and in both cases destroyed their antagonists.

The Common The hen gathering her chickens under her wings

Hen. is a favourite type of motherhood, and it cannot be denied that in many ways the hen shows herself a model parent. The care she will expend upon her brood, or upon a brood of ducks which she may have hatched, is well known, and the courage she will show in their defence is well attested. The following from the "Percy Anecdotes" is an illustration of this: "In June, 1820, a contest of rather an unusual nature took place in the house of $\mathrm{Mr}$. Collins, at Naul in Ireland. The parties concerned were, a hen of the game species, and a rat of the middle size. The hen, in an accidental perambulation round a spacious room, accompanied by an only chicken, the sole surviving offspring of a numerous 
brood, $\boldsymbol{n}$ as roused to madness by an unprovoked attack made by a voracious rat, on her unsuspecting companion. The shrieks of the beloved captive, while dragged away by the enemy, excited every maternal feeling in the affectionate bosom of the feathered dame: she flew at the corner whence the alarm arose, seized the lurking enemy by the neck, writhed him about the room, put out one of his eyes in the engagement, and so fatigued her opponent by repeated attacks of spur and bill, that in the space of twelve minutes, during which time the conflict lasted, she put a final period to the invader's existence ; nimbly turned round, in wild but triumphant distraction, to her palpitating nestling, and hugged it in her victorious bosom." In this same work there is a story of a hen, near Exeter, which devoted itself with much assiduity and success to catching mice. Hens often take to other animals and have been known to show great attachment to kittens, and to dogs, instances being recorded of hens living in dogs' kennels and laying their eggs there under canine protection. The concern shown by hens, when the ducks they may have hatched take to the water, is very amusing. Captain Brown gives an instance of a hen which had become used to this phenomena, from having been employed in hatching successive broods of ducks, and which showed equal concern when a brood of her own chickens avoided the watery element.

ORDER VI. The Hoazin is the only bird of this order.

The Hoazin. It belongs to Brazil and Guiana and is nearly as large as the peacock. It has been variously classified but, differing in important characteristics from any other bird, it is deemed best to place it in an order by itself.

ORDER VII. This order includes the Vultures, Condors, Birds of Prey. Eagles, Kites, Falcons, Goshawks, Sparrowhawks, Buzzards, Kestrals, Owls, \&c., \&c. Interesting as many of these birds are the briefest possible mention is all that we can give of some of them. 
The Fagle. Whatever may be said of the claims of other birds, the Eagle is traditionally the king of the air, as the lion is king of the forest. There are a large number of species of which the Golden Eagle, the Spotted Eagle, the Imperial Eagle and the White-headed Sea Eagle are among the best known varieties. The Golden Eagle belongs to Europe and America, and is sometimes found in Scotland and Ireland. It lives upon smaller birds and animals : hares, young lambs and deer, grouse, plovers, \&c., \&c. Though the eagle has often attacked children the stories of its carrying them away are generally discredited. Eagles often hunt in pairs and show great ferocity and determination in attacking their prey.

Faglo Mr. St. John gives the following description of shooting. a shooting expedition in which he bagged a pair of splendid birds. "On a very dark morning I sallied out with Malcolm to take a shot at the eagles, and at last I was ensconced in a hiding-place (near the dead body of a sheep) which gave me hardly room to stand, sit, or lie. It was scarcely grey dawn when a bird with a slow, flapping flight passed, and alighted out of sight, but near, for I heard him strike the ground, and my heart beat faster. What was my disappointment, when his low, crowing croak announced a raven; he hopped and walked suspiciously round the sheep, till, supposing the coast clear, he hopped upon the carcase, and began with his cut and thrust beak to dig at the meat. Another raven soon joined him, and then two more, who, after a kind of parley, were admitted to their share of the banquet. They suddenly set up a croak of alarm, stopped feeding, and all turned their knowing eyes in one direction. At that moment I heard a sharp scream, but very distant. The black party heard it too, and instantly darted off, alighting again at a little distance. Next came a rushing noise, and the monarch of the clouds lighted at once on the sheep. He quietly folded up his 
wings, and, throwing back his magnificent head, looked round at the ravens, as if wondering at their impudence in approaching his breakfast; they kept a respectful silence, and hopped further away. The royal bird then turned his head in my direction, his bright eye that instant catching mine, as it glanced along the barrel of my gun. He rose, I drew the trigger, and he fell quite dead six yards from the sheep. As one eagle is always followed by a second, I remained quiet, in hopes that his mate was not within hearing of my shot. I had not waited many minutes when I saw the other eagle skimming low over the brow of the hill towards me. She did not alight at once, but her eye catching the dead body of her mate, she wheeled up into the air. I thought she was lost to me, when presently I heard her wings brush close over my head, and she wheeled round and round the dead bird, turning her head downwards to make out what had happened. At times she stooped so low that I could see the sparkle of her eye, and hear her low, complaining cry. I watched the time when she turned up her wing towards me, and dropped her actually on the body of the other. She rose to her feet, and stood gazing at me with a reproachful look, and would have done battle, but death was busy with her, and as I was loading in haste she reeled, and fell perfectly dead."

The

The white-headed or bald eagle, is a native of White-Headed North America, and feeds equally on the produce Eagle.

of the sea and of the land, but is particularly fond of fish. "In procuring these," says Wilson, "he displays in a very singular manner the genius and energy of his character, which is fierce, contemplative, daring and tyrannical, attributes not exerted but on particular occasions, but when put forth overwhelming all opposition." "Elevated," says Wilson, in his "American Ornithology," "on the high dead limb of some gigantic tree, that commands a high view of the neighbouring shore and ocean, he seems calmly to contemplate the motions of the 
varicus feathered tribes that pursue their busy avocations below; the snow-white gulls, slowly winnowing the air; the busy tringæ, coursing along the sands; trains of ducks streaming over the surface; silent and watchful cranes, intent and wading; clamorous crows; and all the winged multitude that subsist by the bounty of this vast liquid magazine of nature. High over all these hovers one, whose action instantly arrests all attention. By his wide curvature of wing, and sudden suspension in the air, he knows him to be the fish-hawk, settling over some devoted victim of the deep. His eye kindles at the sight, and balancing himself with half-opened wings on the branch, he watches the result. Down, rapid as an arrow from heaven, descends the distant object of his attention, the roar of its wings reaching the ear as it disappears in the deep, making the surges foam around! At this moment the looks of the eagle are all ardour; and levelling his neck for flight, he sees the fish-hawk once more emerge, struggling with his prey, and mounting into the air with screams of exultation. This is the signal for the eagle, who, launching in the air, instantly gives chase, and soon gains on the fish-hawk; each exerts his utmost power to mount above the other, displaying in these rencontres the most elegant and sublime aèrial evolutions. The unencumbered eagle rapidly advances, and is just on the point of reaching his opponent, when with a sudden scream, probably of despair and honest execration, the latter drops his fish; the eagle poising himself for a moment, as if to take a more certain aim, descends like a whirlwind, snatches it in his grasp ere it reaches the water, and bears his ill-gotten booty silently away into the woods."

The Vulture. The Vultures have been sometimes called the Hyænas of the feathered world, and judged by their habits, they certainly justify the term. As scavengers they serve a useful purpose in Eastern lands and deserve the protection they are said to receive from the natives. The Griffin 
Vulture of Europe, Turkey, Persia and Africa, the Egyptian Vulture of the Nile country, and the Condor, or American Vulture, are the best known varieties.

The Condor. The American Condor is the largest of the birds of prey, and is said to partake of the ferocity of the Eagle and the filthiness of the Vulture. "Two of these birds, acting in concert," says an American writer, "will frequently attack a puma, a llama, a calf, or even a full-grown cow. They will pursue the poor animal with unwearied pertinacity, lacerating it incessantly with their beaks and talons, until it falls exhausted with fatigue and loss of blood. Then, having first seized upon its tongue, they proceed to tear out its eyes, and commence their feast with these favourite morsels. The intestines form the second course of their banquet, which is usually continued until the birds have gorged themselves so fully as to render themselves incapable of using their wings in flight." This bird is said to measure from three and a half to four feet from head to tail.

The King of This bird which is the handsomest of its tribe the Vultures. is called the King of the vultures, because of the royal honours it receives from common vultures. Mr. Byam says in his "Central America," "One day, having lost a mule by death, he was dragged up to a small hill, not far off, where I knew, in an hour or two, he would be safely buried in vulture-sepulture. I was standing on a hillock, about a hundred yards off, with a gun in my hand, watching the surprising distance that a vulture descries his prey from, and the gathering of so many from all parts, up and down wind, where none had been seen before, and that in a very short space of time. Hearing a loud, whirring noise over my head, I looked up, and saw a fine large bird, with outstretched and seemingly motionless wings, sailing towards the carcase that had already been partially demolished. I would not fire at the bird; for I had a presentiment that it was his majesty of the vultures; but beckoned to an Indian to come up the 
hill-and, showing him the bird that had just alighted, he said, 'the King of the vultures; you will see how he is adored.' Directly the fine-looking bird approached the carcase, the oi polloi of the vultures retired to a short distance; some flew off, and perched on some contiguous branch; while by far the greatest number remained, acting the courtier; by forming a most respectful and well-kept ring around him. His majesty, without any signs of acknowledgment for such great civility, proceeded to make a most gluttonous meal; but, during the whole time he was employed, not a single envious bird attempted to intrude upon him at his repast, until he had finished, and taken his departure with a heavier wing and slower flight than on his arrival; but when he had taken his perch on a high tree, not far off, his dirty, ravenous subjects, increased in number during his repast, ventured to discuss the somewhat diminished carcase; for the royal appetite was certainly very fine. I have since beheld the above scene acted many times, but always with great interest."

A Feast of Wilson gives the following account of the Black

Vultures. Vulture of America. "February 2 Ist, I 809. Went out to Hampstead this forenoon. A horse had dropped down in the street, in convulsions; and dying, it was dragged out to Hampstead, and skinned. I ventured cautiously within thirty yards of the carcase, where three or four dogs, and twenty or thirty vultures, were busily tearing and devouring. Seeing them take no notice, I ventured nearer, till I was within ten yards, and sat down on the bank. Still they paid little attention to me. The dogs being sometimes accidentally flapped with the wings of the vultures, would growl and snap at them, which would occasion them to spring up for a moment, but they immediately gathered in again. I remarked the vultures frequently attack each other, fighting with their claws or heels, striking like a cock, with open wings, and fixing their claws in each other's heads. The females, and I believe the males likewise, made a hissing sound with open 
mouth, exactly resembling that produced by thrusting a red hot poker into water; and frequently a snuffing like a dog clearing his nostrils, as I suppose they were theirs. On observing that they did not heed me, I stole so close that my feet were within one yard of the horse's legs, and I again sat down. They all slid aloof a few feet; but seeing me quiet, they soon returned as before. As they were often disturbed by the dogs, I ordered the latter home: my voice gave no alarm to the vultures. As soon as the dogs departed, the vultures crowded in such numbers, that I counted at one time thirty-seven on and around the carcase, with several within; so that scarcely an inch of it was visible. Sometimes one would come out with a large piece of the entrails, which in a moment was surrounded by several others, who tore it in fragments, and it soon disappeared. They kept up the hissing occasionally. Some of them having their whole legs and heads covered with blood, presented a most savage aspect. Sometimes I observed them stretching their neck along the ground, as if to press the food downwards." The Secretary The Secretary Bird, so called from the possession Bird. of feathers thought to resemble pens behind the ear, feeds on snakes and other reptiles. Le Vaillant, who in dissecting one of these birds, found in his crop eleven large lizards, three serpents each a yard in length, eleven small tortoises and a great quantity of locusts and other insects, once witnessed a contest thus referred in the "Percy Anecdotes":

"When the secretary approaches a serpent, it always carries the point of one of its wings forward, in order to parry off its venomous bites; sometimes it finds an opportunity of spurning and treading upon its antagonist; or else, of taking him upon its pinions, and throwing him into the air. When by this system it has, at length, wearied out its adversary, and rendered him almost senseless, it kills and swallows him at leisure. On the occasion which Vaillant mentions, the 
battle was obstinate, and conducted with equal address on both sides. The serpent, feeling at last his inferiority, endeavoured to regain his hole; while the bird apparently guessing his design, stopped him on a sudden, and cut off his retreat by placing herself before him at a single leap. On whatever side the reptile endeavoured to make his escape, the enemy still appeared before him. Rendered desperate, the serpent resolved on a last effort. He erected himself boldly to intimidate the bird, and hissing dreadfully, displayed his menacing throat, inflamed eyes, and a head swollen with rage and venom. The bird seemed intimidated for a moment, but soon returned to the charge; and covering her body with one of her wings as a buckler, struck her enemy with the bony protuberance of the other. M. Vaillant saw the serpent at last stagger and fall; the conqueror then fell upon him to despatch him, and with one stroke of her beak laid open his skull."

The Kite. The Kite is common in Europe and is someThe Osprey. times seen in Scotland. It is a bird of the Hawk The Buzzard. kind and may easily be distinguished from other birds of prey by its forked tail and the slow and circular eddies it describes in the air whenever it spies its prey. It measures about two feet in length. The Osprey is common in Europe and America. It feeds principally upon fish, in pursuit of which it frequents the sea coast and the borders of lakes and rivers. It is about two feet in length. The common Buzzard is rather smaller, measuring twenty or twentytwo inches. It nests on high trees and watches on overhanging branches for any prey that may pass beneath. The Marsh Harrier which measures twenty-one to twenty-three inches is a formidable foe to moles and mice, rabbits and reptiles. The Falcon. The Peregrine Falcon so famous in the days of Falconry is a fearless bird and does not hesitate to attack those of much larger size. For this reason it was often employed in hunting the Heron. "In this contest," says 
Mr. Wood, "the Falcon was almost always victorious, and after it had attained a sufficient altitude, it swept, or 'stooped', as the phrase was, upon the Heron. When the Falcon had closed with its prey, they both came to the ground together. Sometimes, however, the wary Heron contrived to receive its enemy on the point of its sharp beak, and transfixed it by its own impetus." This bird is from fifteen to eighteen inches in length. Mr. Selby in his "Ornithology" says, "In daring disposition, this bird equals most of its congeners. I may be allowed to add the following instance, as having happened under my own observation, and as exemplifying not only its determined perseverance in pursuit of its prey, when under the pressure of hunger, but as arguing also an unexpected degree of foresight:-In exercising my dogs upon the moors, previous to the commencement of the shootingseason, I observed a large bird of the hawk genus, hovering at a distance, which, upon approaching, I knew to be a Peregrine Falcon. Its attention was now drawn towards the dogs, and it accompanied them, whilst they beat the surrounding ground. Upon their having found, and sprung a brood of grouse, the falcon immediately gave chase, and struck a young bird, before they had proceeded far upon wing. My shouts and rapid advance, prevented it from securing its prey. The issue of this attempt, however, did not deter the falcon from watching our subsequent movements, and another opportunity soon offering, it again gave chase, and struck down two birds, by two rapidly repeated blows, one of which it secured, and bore off in triumph."

The

The Sparrow-hawk which measures from twelve

sparrow to fifteen inches long is a terror to smaller

Hawk. birds, showing great pertinacity in their pursuit. Mr. St. John says that one pursued a pigeon through his "drawing-room window, and out at the other end of the house through another window, and never slackened its pursuit, notwithstanding the clattering of the broken glass of 
the two windows as they passed through," and that on another occasion he found "a sparrow hawk deliberately standing on a very large pouter pigeon on the drawing-room floor, and plucking it, having entered in pursuit of the unfortunate bird through an open window, and killed him in the room." White says, in his "Natural History of Selborne," "About the tenth of July, a pair of sparrow-hawks bred in an old crow's nest on a low beech in Selbornehanger; and as their brood, which was numerous, began to grow up, they became so daring and ravenous, that they were a terror to all the dames in the village that had chickens or ducklings under their care. A boy climbed the tree, and found the young so fledged that they all escaped from him; but discovered that a good house had been kept; the larder was well stored with provisions; for he brought down a young blackbird, jay, and house martin, all clean picked, and some half devoured. The old birds had been observed to make sad havoc for some days among the new flown swallows and martins, which, being but lately out of their nests, had not acquired those powers and command of wing that enable them when more mature to set enemies at defiance."

The Owl. Great interest attaches to the owl from the singularity of its appearance and habits. There are many varieties, the Common Barn Owl; the Long-eared Owl; the Great Eagle Owl; and the American Horned Owl being some of these. The Barn Owl measures about twelve inches in length. This bird does great service in the destruction of mice, rats, and other vermin, and it is the nemesis of fate that it is destroyed by those it serves. Its movements are noiseless, the peculiar form of the feathers of its wings enabling it to fly without making any sound, and so surprise its prey. "Its method of devouring a mouse," says Mr. Wood, "is quite different from the mode in which it eats a bird. If a mouse is given to an owl, the bird seizes it across the back, and gives it one or two smart bites, much as a terrier handles a 
rat. The mouse is then jerked upwards, and caught again head downwards. A second jerk sends the mouse half down the owl's throat, while its tail remains sticking out of the side of its bill, where it is rolled about as if the owl were smoking. After some time has been spent in this amusement, another jerk causes the mouse to disappear altogether, and the owl looks very happy and contented. But if a small bird is presented to it, the owl tears it up and devours it piecemeal." The great Eagle Owl which measures two feet and upwards will attack hares, rabbits, and young fawns. ORDER VIII. The order of wading birds includes many Wading Birds. that we can do no more than mention:- the Moor Hen; the Woodcock; the Snipe; the Water pheasant; the Plover; the Lapwing; the Crane; the Heron; the Stork; and the Flamingo are the more familiar birds of the order, which however includes the Crakes; the Coots; the Curlews; the Bustards; the Sandpipers, and others.

The Cranes. The Cranes belong to Africa and Southern Asia, but migrate from clime to clime as the seasons change. The flight of the Cranes, like that of some other birds, is a compact and well ordered progression. They fly high and commonly at night, apparently under the direction of a leader whose course they follow and whose calls they obey. There are several varieties, the Common Crane, the Numidian Crane, and the Balearic Crane being the better known of these. The Heron. The Heron is an expert fisherman and has all the necessary patience for the pursuit of his sport. He will stand motionless for hours at the water side, waiting his opportunity, and then dart with unerring aim at the unsuspecting fish and secure his meal. The bill of ? the heron is a powerful weapon, and as we remarked when dealing with the falcons, formerly used in hunting the heron, it will sometimes transfix the Falcon by throwing its head back and receiving its enemy on the point. Captain Brown gives an illustration which shows that the Heron's bill may be as effective in 
other cases. "A gentleman being on a shooting excursion, accompanied by a small spaniel, observed a heron wading a little above a waterfall. He fired-wounded it-and sent his dog into the stream to bring it to land. As soon as the dog had come within its reach, the heron drew back its head, and with all its force, struck him in the ribs with its bill. The gentleman again fired, and killed the heron; but it had well revenged itself: both dog and heron floated dead together, down the foaming waterfall." The Heron nests on the tops of high trees and lives in companies.

The Bittern. The Bittern is remarkable for its loud booming cry which has some resemblance to the bellowing of a bull, and for its spiral flight which it pursues to a great altitude.

The stork. Storks are found in different parts of Europe, Asia and Africa. In Holland, and in some other countries, they live in a state of semi-domestication, encouraged by the people, and building nests upon the roofs of their houses. They feed on rats, mice, frogs, and other vermin, and render the Hollander good service by keeping down the numbers of such pests. In the East they act as scavengers, and for this reason are as much encouraged by the people. "A recent visitor to Constantinople," says Mr. Wood, "remarks that the very Storks seemed to have become Ottoman, for they sat on the tops of the houses, looking staid and solemn, as becomes the Oriental character, and managed their beaks just as if they were pipes. It is true that they wore no turbans, but each of them appeared to have left a turban of preposterous dimensions, viz., his nest, on the roof of a house close by." The Stork is easily tamed and sometimes shows considerable intelligence.

The Jealousy The following illustration which we take from of the Stork. the "Percy Anecdotes" shows that the Stork shares with other birds the feeling of jealousy. "In Smyrna there are a great number of storks, who build their nests and hatch their young very regularly. The inhabitants, in order to divert 
themselves at the expense of these birds, and gratify a cruel disposition, sometimes convey hens' eggs into the stork's nest; and when the young are hatched, the cock on seeing them of a different form from his own species, makes a hideous noise, which brings a crowd of other storks about the nest, who to revenge the disgrace which they imagine the hen has brought upon her race, immediately peck her to death. The cock in the meantime makes the heaviest lamentation, as if bewailing his misfortune, which obliged him to have recourse to such extreme punishment."

A stork's From the same work we quote the following, Revenge. which shows that though ordinarily placid and placable the stork can cherish the feeling of revenge. "A wild stork was brought by a farmer in the neighbourhood of Hamburgh, into his poultry yard, to be the companion of a tame one, which he had long kept there; but the tame stork disliking a rival, fell upon the poor stranger, and beat him so unmercifully that he was compelled to take wing, and with some difficulty escaped. About four months afterwards, however, he returned to the poultry yard, recovered of his wounds, and attended by three other storks, who no sooner alighted, than they all together fell upon the tame stork, and killed it."

ORDER IX. This order includes the Goose, the Duck,

The Geese. the Swan, the Teal, the Gull, the Petrel, the Albatross, the Cormorant, the Pelican, the Penguin, the Grebe, the Great Auk, the Puffin and other birds. The first of these is found in all parts of the world, geese being especially cultivated in England for the sake of their quills and feathers, and for the purposes of food. The goose, far from being the foolish bird it is popularly esteemed, often shows considerable intelligence, as well as great affection for those who show it kindness.

The

Many instances are recorded of gratitude shown Gratitude of by geese towards those who have befriended the Goose. them. Buffon once rescued a young gander from 
an older and stronger bird, after which his young protege would follow him on all his daily walks, never tiring of his company. "On one occasion," says Buffon, "he heard me talking in the rector's upper room, and as he found the front door open, climbed upstairs, and, marching into the room, gave a loud exclamation of joy, to the no small astonishment of the family."

A wild Bishop Stanley, in his "Familiar History of Goose Chsse. Birds," says :- "An officer settled on a farm near the Missouri in North America, one day, when walking near the banks of the river, observed a large eagle frequently darting towards the water, and then rising again. On a near approach, he perceived that its object was to take a wild goose, which had alighted on the water, and which was diving to avoid so powerful an enemy. Its efforts, however, appeared to be in vain; and, after diving again and again, and as often rising to get breath, it became nearly exhausted, when, suddenly turning, it made for the shore with all speed towards the officer's house, where two men were at work, and as soon as it had landed walked leisurely up to them, permitting itself to be taken without attempting to escape. It was completely exhausted, but soon recovered, and within three days seemed quite contented, and confident of protection."

Goose

There are some curious instances known of Friendships. friendships formed by geese for both men and animals, apparently without any special reason. A goose in Cheshire once followed a farmer with so much persistency, at the plough, to the market, and in the house, that the farmer who had shown it no special kindness, superstitiously regarded it as a bird of ill omen and had it killed. A singular friendship grew up some years ago between a gander at York and an old man who lived near the farm to which the bird belonged. In this case the gander waddled off in the morning and spent theday with his human friend, returning at night to its home at the farm. One of the 
prettiest of these stories is that of a gander in Germany who used to lead a blind woman to church, taking the corner of her apron in his beak, and wait quietly in the churchyard until the service was over to conduct her home again. Another goose was known to have a great affection for soldiers and to regularly perform sentry duty, walking backwards and forwards for hours with his red-coated friends.

The Goose and A more singular friendship than any perhaps, the Dog. was that existing between a goose and a dog, thus described in "The Philosophical Magazine":-

"A species of goose, a native of Africa, belonging to a person in Scotland, was observed some time ago to pay particular attention to a dog which was chained up; a dog which had previously manifested a great dislike to poultry, never allowing them to come within reach of his chain. The goose, finding she had nothing to fear from her canine friend, would enter his kennel, in the centre of which, among the straw, she made her nest and deposited her eggs, which was not known till one of the family mentioned that the goose slept in the dog's bosom. The singularity of the circumstance led to, an examination of the box, but not without the greatest reluctance on the part of the dog, who appeared determined to protect what was left to his charge. On removing the straw, five eggs were discovered in a fine bed of down and feathers. The dog was in the habit of going into his box with the greatest care, for fear of injuring the eggs."

The Maternal The Rev. C. A. Bury gives a pathetic illustraInstinct of the tion of the maternal instinct of the goose:-

Goose.

"An old goose, that had been for a fortnight hatching in a farmer's kitchen was perceived on a sudden to be taken violently ill. She soon after left the nest, and repaired to an outhouse where there was a young goose of the first year, which she brought with her into the kitchen. The young one immediately scrambled into the old one's 
nest, sat, hatched, and afterwards brought up the brood. The old goose, as soon as the young one had taken her place, sat down by the side of the nest, and shortly after died. As the young goose had never been in the habit of entering the kitchen before, I know of no way of accounting for this fact than by supposing that the old one had some way of communicating her thoughts and anxieties, which the other was perfectly able to understand. A sister of mine, who witnessed the transaction, gave me the information in the evening of the very day it happened." The Rev. F.C. Morris tells of a goose which had a number of ducks' eggs placed with some of her own that she might hatch them, but which twice removed the ducks' eggs from the group, declining to sit on any but her own.

The Duok. The many varieties of Ducks might well occupy much more space than we can spare for them. The better known of these are the Wild Duck, the Common Duck, the Eider Duck, the Long-tailed Duck, the King Duck, the Canvas-back Duck, the Mallard, the Teal, the Widgeon, the Mandarin, and the Common Shelldrake.

An interesting illustration of the affection which ducks sometimes show towards each other is given by Dr. Stanley. He says:- "A pair of Muscovy Ducks were landed at Holyhead from a Liverpool vessel, returning from the coast of Africa. The male was conveyed to a gentleman's house, and put with other ducks, towards whom he evinced the utmost indifference: he evidently pined for the loss of his mate; but she was brought after a time, and let loose; he did not at first see her, but when, on turning his head, he caught a glimpse of her, he rushed towards her with a joy which was quite affecting. Nothing after that would induce him to quit her; he laid his beak upon hers, nestled his head under her wing, and often gazed at her with the greatest delight."

The swan. The Swan is one of the most graceful of the bird kind, the purity of its colour and the beauty of its 
form as it glides along the river making it one of the prettiest sights in nature. There are several varieties of the swan, of which the Whooping Swan and the Common Swan of Europe, the Black Swan of Australia, and the Black-necked Swan of South America are the most familiar.

The Maternal

The swan is assiduous in the care of her young, Instinct of the and shows great intelligence in providing for

Bwan. them as well as courage in their defence. She makes her nest in the grass among reeds; and in February begins to lay, depositing egg after egg, until there are six or eight. Dr. Latham mentions two females that for three or four years successively, agreed to associate, and had each a brood yearly, bringing up together about eleven young ones: they sat by turns, and never quarrelled. Captain Brown gives a remarkable illustration of the courage of a swan in defending her nest. He says:- "A female swan, while in the act of sitting, observed a fox swimming towards her from the opposite shore: She instantly darted into the water, and having kept him at bay for a considerable time with her wings, at last succeeded in drowning him; after which, in the sight of several persons, she returned in triumph. This circumstance took place at Pensy, in Buckinghamshire."

The Swan's Mr. Yarrell, in his "British Birds," mentions a Intelligence. remarkable instance of the sagacity and intelligence of the swan: "A female swan was sitting on four or five eggs. One day she was observed to be very busy in collecting weeds, grasses, and sticks, to raise her nest above its usual level. A kind-hearted farming man threw her some handfuls of brushwood, with which she most industriously raised her nest, and soon placed the eggs about two feet and a half above the old level. That night there came down a tremendous fall of rain, which flooded all the fields and cellars, and did great damage in the village. Man made no preparation-the bird did; and instinct prevailed over reason! Her eggs were above, and only just above, the water." 
The Bwan Swans are said to be spiteful at times, and to and the show a savagery of temper on occasion, for which, Fawn. as in the following case, it is difficult to account. "In the park of Lord Grantley at Wonersh, near Guildford, a fawn, drinking, was suddenly pounced upon by one of the swans, which pulled the animal into the water, and held it under until quite drowned. This action was observed by the other deer in the park, and did not long go unrevenged; for shortly after, this very swan, which had hitherto never been molested by the deer, was singled out when on land, and furiously attacked by a herd, which surrounded and killed it."

The

The Gulls are a numerous family, the Common

Common Gull, the Herring Gull, the Great Black-Backed

Bea-Gull. Gull and the Ivory Gull being well known species. The Common Gull is found everywhere. It frequents the coasts of continents and islands and feeds principally upon fish, though its voracity is very accommodating, and its taste not over fastidious.

A Tamo Many years ago, Mr. Scot, of Benholm, near Bea-gull. Montrose, caught a sea-gull, and having cut its wings put it into his garden. The bird remained in this situation for several years, and being kindly treated, became so familiar, as to come at call to be fed at the kitchen door and to answer to the name of Willie. It became so tame at last that no pains were thought necessary to circumscribe its liberty, and its wings having grown to full length, it flew away, joined the other gulls on the beach, and rame back, from time to time, to pay a visit to the house. When its companions left the country at the usual season, Willie accompanied them, much to the regret of the family. To their great joy, however, it returned next season; and with its usual familiarity came to its old haunt, where it was welcomed and fed very liberally. In this way it went and returned for forty years, without intermission, and kept up its acquaintance with the family, for while in the country it visited them 
almost daily, answered to its name like any domestic animal, and ate almost out of the hand. One year, however, very near the period of its final disappearance, Willie did not pay his respects to the family for eight or ten days after the general flock of gulls were upon the coast, and great was their lamentation for his loss, as it was feared he was dead: but to the surprise and joy of the family, a servant one morning came running into the breakfast-room with delight, announcing that Willie was returned. The whole company rose from the table to welcome the bird. Food was supplied in abundance, and Willie with his usual frankness ate of it heartily, and was as tame as any barn-yard fowl about the house. In a year or two afterwards this grateful bird disappeared for ever.

Mother

The Stormy Petrel or Mother Carey's Chicken,

Carey's is a small black bird well known to mariners, and

Chicken. familiar to all at sea in stormy weather. It follows in the wake of ships and is regarded as a prophet of evil, at least in so far as stormy weather is concerned. It is seen in many parts of the ocean busily engaged in searching for food, braving the fury of the storm and skimming along the waves, sometimes above their tops, and sometimes screening itself from the blast by sinking down into the billows between them. It nests in all but inaccessible places, the Island of St. Kilda being the chief British breeding place of the Fulmar variety. These are of great importance to the natives who run great risks in searching for their eggs and who catch the birds for the purposes of food, and for the oil which they supply.

Catching the The danger attaching to the capture of the stormy Petrel in its rocky haunts in the Hebrides is thus Petrel. vividly described by Mr. Drosier. "As the stormy petrel, is scarcely ever to be seen near the land, except in very boisterous weather, one of the natives for a trifling remuneration, agreed to traverse the face of a rock, and take 
me some from out its fissures. Accordingly, accoutred with a rope of hemp and hogs' bristles coiled over his shoulders, he proceeded to the cliff. Having made one end fast by means of a stake, he threw the coil over the face of the rock, and gradually lowered himself down, but with the utmost caution and circumspection, carefully pressing his foot hard upon the narrow ridges before he at all loosened his firm grasp of the rope, which he never altogether abandoned. I had previously thrown myself upon my chest, to enable me to have a better view of him, by looking over the cliff; and, certainly, to see the dexterity and bravery with which he threw himself from one aperture to another, was truly grand. The tumbling roar of the Atlantic was foaming many hundreds of feet beneath, and dashing its curling cream-like surge against the dark base of the cliff, in sheets of the most beautiful white; while the herring and black-backed gulls, alternately sweeping past him so as to be almost in reach of his arm, threw a wildness into the scene, by the discordant scream of the former, and the laughing, oft-repeated bark of the latter. This, however, he appeared entirely to disregard; and continuing his search, returned in about half an hour, with seven or eight of the stormy petrels, tied up in an old stocking, and a pair of the Manks puffins, together with their eggs. The birds, he told me, he had no difficulty in capturing. The eggs of the stormy petrel are surprisingly large, considering the diminutive size of the bird, being as large as those of the thrush. The female lays two eggs, of a dirty or dingy white, encircled at the larger end by a ring of fine rust-coloured freckles. The birds merely collect a few pieces of dried grass, with a feather or two, barely sufficient to prevent the eggs from rolling or moving on the rock."

The Cormorant. The Common Cormorant is familiar all round the coast of England, and will even sometimes venture inland or at any rate up the mouths of rivers. Captain Brown mentions one that, many years ago, was seen resting upon 
the vane of St. Martin's steeple, Ludgate Hill, London; and was shot in the presence of a large number of people. It is a voracious bird and shows great dexterity in the catching and swallowing of fish, turning them round so as to swallow them head foremost, in order to avoid the resistance of the fins and spines. Colonel Montague had one, caught in a tributary of the Bristol Channel, by a Newfoundland dog, which at first refused food but offered no resistance to being crammed. "The Colonel having retired to the library after seeing the bird fed," says Captain Brown, "was surprised in a few minutes to see it walk boldly into the room, unceremoniously place itself by him at the side of the fire, and begin to dress its feathers. This practice it continued till removed to an aquatic menagerie. Whenever it saw the water it became restless, and on being set at liberty, plunged into it, and incessantly dived for a considerable time in search of fish. After this, it seemed to be convinced that there were none to be found there, as it was not noticed to dive again for three days."

The Albatross. The great Albatross is a large and powerful bird, measuring three feet in length and having a stretch of wing of from nine to twelve or fourteen feet. It is a heavy bird, and needs great strength to sustain its weight during its long and rapid flights. Mrs. Bowdich says, "One was known to follow a ship, which made two hundred miles a day, for forty-eight hours; and besides these miles, from its irregular flight, it must have passed over a much longer distance. The Albatross darts with unerring aim and great force on its prey, as it swims on the top of the waves. A man who fell overboard near the island of St. Paul's was killed 'by these birds; for, although the boat was lowered immediately, nothing was found of him except his hat, pierced through and through by the beaks of three albatrosses, who had marked him, pecked him on the head, and caused him to sink." Their flight is easy and apparently performed without 
effort and with an almost imperceptible movement of wing. The Albatross is easily caught from the stern of a ship with a hook. Mr. Wood says: "It seems rather remarkable that a bird that lives in or over the sea during its whole life, should prove a landsman when taken on board. Yet, when the Albatross is caught and placed on deck, it begins to stagger about, and soon becomes as thoroughly sea sick as the most inexperienced cockney." Mr. Earl thus describes the haunt of the Albatross in the heights of the Island of Tristan d'Acunha: "A death-like stillness prevailed in these high regions, and to my ear our voices had a strange unnatural echo, and I fancied our forms appeared gigantic, whilst the air was piercing cold. The prospect was altogether sublime, and filled the mind with awe. The huge Albatross here appeared to dread no interloper or enemy; for their young were on the ground completely uncovered, and the old ones were stalking around them."

The Pelican. The Pelican is one of the largest of swimming birds. It is distinguished by the possession of a pouch. which is capable of holding two gallons of water, and which it uses for the purposes of catching fish, and feeding its young. In this latter operation the bird presses its pouch which hangs beneath its beak, against its breast, and so disgorges its contents. This action is said to have given rise to the fable that pelicans pluck nourishment from their own breasts to feed their young. The Pelican belongs to the South and East of Europe and the North of Africa.

A Tame Mr. Hill, of St. Domingo, gives an interesting

Pelicen. account of a tame pelican which is quoted by Mrs. Bowdich. He says:- "The facility with which the pelican resigns itself to fasting or feasting, was very interestingly exhibited to me in a bird I saw the other day at Passage Fort. It was a pelican of mature age; it flew backwards and forwards, visiting the wild flocks, and feeding with them in the harbour during the day, and withdrew from 
them to roost in its master's yard during the night. In that period of restraint, when it was necessary to observe the caution of drawing its quill feathers, to keep it within diminished capabilities of flight, until it became familiar and domesticated, it was wholly dependent on the fish provided for it by the fishermen of the beach. Sunday was no fishing day with these men; and this was, therefore, a day in which there were no supplies for the pelican. It became, in time, so conscious of the recurrence of this fast-day, that although, at all other times, it went daily down to the sea-side to wait the coming in of the canoes, on the seventh day it never stirred from the incumbent trunk of a tree, on which it roosted, within the yard. It had been found necessary to pluck its wings within the last two or three months, to restrain it within bounds, in consequence of its absence latterly with the wild birds, for several days in succession, and in this state it was reduced, as formerly, to depend on the fishermen for food. The old habit of abstinence and drowsy repose on the Sundays again recurred, and when I saw it, it was once more a tranquil observer of the rest, and with it the fast, of the Sabbath-day."

The Penguin. The Penguin belongs to South America, Australia, New Zealand and the Cape of Good Hope. There are a number of species; the Jackass Penguin, so called from the peculiarity of its cry, the King Penguin of the South Pacific, and the Cape Penguin of Cape Horn, the largest of the penguins, being the principal varieties. Mr. Darwin in describing the Jackass penguin says:- "In diving, its little plumeless wings are used as fins, but on the land as front legs. When crawling (it may be said on four legs) through the tussocks, or on the side of a grassy cliff, it moved so very quickly that it might readily have been mistaken for a quadruped. When at sea and fishing, it comes to the surface, for the purpose of breathing, with such a spring, and dives again so instantaneously, that I defy any one at first sight 
to be sure that it is not a fish leaping for sport." The penguin is a courageous bird, and will not hesitate to attack a man. Mr. Darwin when on the Falkland Islands, placed himself between one of the Patagonian penguins and the water, and till it reached the sea, it regularly fought and drove him backwards. It stood close before him, erect and determined, and every inch gained it firmly kept. Nothing less than heavy blows would have stopped it.

The Puffin. The Puffin is a bird of singular appearance and interesting habits. It is sometimes called the sea parrot from the resemblance of its head to that of the Parrot kind. The bird measures thirteen inches in length, and its bill is a formidable weapon. The Raven seems to be its natural enemy, and when they come to close quarters a great deal depends upon which succeeds in getting the first grip. Naturally each bird has the best chance in its own element. It is a bird of passage, visiting its customary breeding places in the summer and wintering in southern Europe. Mr. Rennie says, "In the breeding season, numerous troops of them visit several places on our coasts, particularly the small island of Priestholm, near Anglesey, which might well be called puffin land, as the whole surface appears literally covered with them. Soon after their arrival in May, they prepare for breeding, and it is said, the male, contrary to the usual economy of birds, undertakes the hardest part of the labour. He begins by scraping up a hole in the sand not far from the shore; and after having got some depth he throws himself on his back, and with his powerful bill as a digger and his broad feet to remove the rubbish, he excavates a burrow with several windings and turnings, from eight to ten feet deep. He prefers, where he can find a stone, to dig under it, in order that his retreat may be more securely fortified. Whilst thus employed, the birds are so intent upon their work that they are easily caught by the hand," 
ORDER X. This order includes the Ostrich, the Rhea, the The Cassowaries and the Emus. The Ostrich beOstriohes, longs to Africa, Australasia, and South America. It is the largest of the birds, attaining to a height of six feet, and a weight of three hundred pounds. It is hunted for the sake of its feathers, but being very swift of foot has to be circumvented by strategy. It is said to run in large curves, which habit gives the hunter the opportunity of riding straight and intercepting it. "A favourite method adopted by the wild Bushman for approaching the Ostrich and other varieties of game," says Captain Cumming, "is to clothe himself in the skin of one of these birds, in which, taking care of the wind, he stalks about the plain, cunningly imitating the gait and motions of the Ostrich, until within range, when, with a well-directed poisoned arrow from his tiny bow, he can generally seal the fate of any of the ordinary varieties of game." The eggs of the Ostrich are also much prized. "The nest," says Captain Cumming, "is merely a hollow scooped in the sandy soil, generally amongst heath or other low bushes; its diameter is about seven feet; it is believed that two hens often lay in one nest. The hatching of the eggs is not left, as is generally believed, to the heat of the sun, but, on the contrary, the cock relieves the hen in the incubation. The eggs form a considerable item in the Bushman's cuisine, and the shells are converted into water flasks, cups, and dishes. I have often seen Bush-girls and Bakalahari women, who belong to the wandering Bechuana tribes of the Kalahari desert, come down to the fountains from their remote habitations, sometimes situated at an amazing distance, each carrying on her back a kaross, or a net-work containing from twelve to fifteen ostrich egg-shells, which had been emptied by a small aperture at one end; these they fill with water."

The Ostrioh The Ostrich shows the same affection for its and its Young. mate, and the same devotion to the care of its 
young that we have noticed in other birds, and in animals. The female of a pair in Paris died through swallowing a three-cornered piece of glass which a glazier had dropped into their cage, after which the mate pined away and died in a few weeks. Of their care of their young Captain Cumming says:

"I fell in with a troop of about twelve young ostriches, which were not much larger than Guinea-fowls. I was amused to see the mother endeavour to lead us away, exactly like a wild duck, spreading out and drooping her wings, and throwing herself down on the ground before us as if wounded, while the cock bird cunningly led the brood away in an opposite direction." Professor Thunberg once rode past the place where a hen Ostrich was sitting in her nest; when the bird sprang up, and pursued him, evidently with a view to prevent his noticing her eggs or young. Every time he turned his horse towards her she retreated ten or twelve paces; but as soon as he rode again she pursued him, till he had got to a considerable distance from the place where he had started her.

The Rhea. The Rhea is a beautiful bird of the ostrich The Cassowary. type belonging to South America. There are The Irmu. several species, known as the Common Rhea, the Great-billed Rhea, and Darwin's Rhea, the latter belonging to Patagonia. A Common Rhea bred some time ago in the Zoological gardens, when the male bird discharged the duties of incubation. The Cassowary and the Emu belong to Australia. The Cassowary resembles the ostrich in form, but is not so large. It stands about five feet. Like all these birds it is unable to fly, but is very swift of foot. It can kick too, with great violence, as dogs have sometimes found to their cost. The Emu is a very large bird and is said sometimes to exceed six feet in height.

Mr. Bennett says:- "The length of its legs and the muscularity of its thighs enable it to run with great swiftness; and as 
it is exceedingly shy, it is not easily overtaken or brought within gun-shot. Captain Currie states that it affords excellent coursing, equalling if not surpassing the same sport with the hare in England; but Mr. Cunningham says that dogs will seldom attack it, both on account of some peculiar odour in its flesh which they dislike, and because the injuries inflicted upon them by striking out with its feet are frequently very severe. The settlers even assert that the Emu will break the small bone of a man's leg by this sort of kick; to avoid which, welltrained dogs run up abreast, and make a sudden spring at the neck, whereby the bird is quickly dispatched. Its flesh has been compared to coarse beef, which it resembles both in appearance and taste." Mr. Jesse says, "The only instance I have met with in which the hen bird has not the chief care in hatching and bringing up the young, is in the case of the Emus, at the farm belonging to the Zoological Society, near Kingston. A pair of these birds bred five young ones: the female, at different times, dropped nine eggs in various places in the pen in which she was confined. These were collected in one place by the male, who rolled them gently and carefully along with his beak. He then sat upon them himself, and continued to do so with the utmost assiduity, for nine weeks, during which time the female never took his place, nor was he ever observed to leave the nest. When the young were hatched, he alone took charge of them, the female not appearing to notice them in any way. On reading this anecdote, many persons may suppose that the female emu is not possessed of that natural affection for its young which other birds have. In order to rescue it from this supposition, I will mention that a female emu belonging to the Duke of Devonshire at Chiswick, laid some eggs; and as there was no male bird, she collected them together herself, and sat upon them." The Apteryx, the wingless bird of New Zealand, belongs to this order. 


\title{
NATURAL HISTORY IN ANECDOTE.
}

\author{
VERTEBRATA.
}

\section{CLASS III-REPTILIA.}

ORDER I. This order introduces us to creatures differing The Tortoise and very widely, in form and character, from those which we have been considering. There are more The Turtle. than two hundred species of the tortoise, and these are grouped into four families. The Common European tortoise is found in the South of France and Italy, as well as in Sicily and Greece. It feeds on vegetables, and under favourable circumstances lives a great number of years. It is slow in its movements but it burrows rapidly and is soon out of sight in the sandy soil it affects. Tortoises are commonly kept in a state of domestication in England, one known to the writer showing a great preference for pansies, eating the flowers and leaving the other parts of the plant. Mr. Wood describes the efforts made by a tortoise in his possession to attain the summit of a footstool, which shows that the reptile has some measure of intelligence. "Unfit as the form of the creature may seem for such a purpose," says Mr. Wood, "it did contrive to scramble upon a footstool which was placed by the fender. Its method of attaining this elevation was as follows:- First it reared up against the footstool in the angle formed by it and the fender, and after several ineffectual attempts, succeeded in hitching the claws of one of its hind feet into the open work of the fender. On this it raised itself, and held on to the top of the stool by its 
fore feet, while it gained another step on the fender, and so managed to raise itself to such a height, that it only had to fall flat on the top of the footstool. When once there, it could hardly be induced to leave the elevation which it had gained with such difficulty."

The Flephant The gigantic tortoises of the Galapagos Islands

Tortoise. came under the observation of Mr. Darwin, from whom we quote the following descriptive passages: "These animals are found, I believe, in all the Islands of the Galapagos Archipelago. They frequent in preference the high damp parts, but likewise inhabit the lower and arid districts. Some individuals grow to an immense size. Mr. Lawson told us that he had seen several so large that it required six or eight men to lift them from the ground, and that some had afforded as much as two hundred pounds of meat. This tortoise is very fond of water, drinking large quantities and wallowing in the mud. The larger islands alone possess springs, and these are always situated towards the central parts and at a considerable elevation. The tortoises, therefore, which frequent the lower districts, when thirsty have to travel from a long distance. Hence broad and well beaten paths radiate off in every direction from the wells, even down to the sea coasts, and the Spaniards by following them up first discovered the watering-places. Near the springs it was a curious spectacle to behold many of these great monsters; one set eagerly travelling onwards with outstretched necks, and another set returning, having drunk their fill. The tortoises when moving towards any definite point, travel by night and day, and arrive at their journey's end much sooner than would be expected. One large tortoise, which I watched, I found walked at the rate of sixty yards in ten minutes, that is three hundred and sixty in the hour, or four miles a day, allowing also a little time to eat on the road. During the breeding season, when the male and female are together, the male utters a hoarse roar or bellowing, which, it is said, 
can be heard at a distance of more than a hundred yards. The female never uses her voice and the male only at such times. They were at this season (the month of October) laying their eggs. The female, where the soil is sandy, deposits them together and covers them up with sand; but where the ground is rocky she drops them indiscriminately in any hollow. Mr. Bynoe found seven placed in a line on a fissure. The egg is white and spherical ; one which I measured was seven inches and three-eighths in circumference. The inhabitants believe that these animals are absolutely deaf; certainly they do not overhear a person walking close behind them. I was always amused when overtaking one of these great monsters as it was quietly pacing along, to see how suddenly, the instant I paused, it would draw in its head and legs, and uttering a deep hiss, fall to the ground with a heavy sound as if struck dead. I frequently got on their backs, and then, upon giving a few raps on the hinder parts of the shell, they would rise up and walk away, but I found it very difficult to keep my balance. The flesh of these animals is largely employed, both fresh and salted; and a beautiful clear oil is prepared from the fat. When a tortoise is caught, the man makes a slit in the skin, near its tail, so as to see inside its body whether the fat under the dorsal plate is thick. If it is not, the animal is liberated; and is said to recover soon from this strange operation. In order to secure the tortoises it is not sufficient to turn them, like turtles, for they are often able to regain their upright position."

The Turtle. The Green Turtle is the turtle of the famous soup. It is a large animal, measuring five or six feet in length and weighing from five hundred to six hundred pounds; it feeds on sea-weeds and is found in large numbers in the seas of warm latitudes. The species from which we get the horny substance known as tortoiseshell (Chelonia Imbricata) is sometimes called the Hawk's-bill turtle. It is a smaller variety, measuring about three feet and belonging to tropical 
seas. The Leathery Turtle is said to reach eight feet in length and a weight of a thousand pounds. The Loggerhead Turtle is even larger than this, and sometimes weighs as much as fifteen hundred pounds.

ORDER II. The Crocodile and the Alligator belong The Crocodile. respectively to the Eastern and the Western Worlds. The former infests the rivers of Africa and Asia, one species at least belonging to Australia. Some of the best known varieties are those of the river Nile, the Gavial of the Ganges being also among the more familiar species. These formidable and unwieldy monsters grow to an immense size, sometimes attaining to a length of twenty-five feet. Their enormous jaws and innumerable sharp teeth (they sometimes number a hundred) give them a terrible appearance, while their hard scaly coats are invulnerable against ordinary attack. Their point of weakness is their unwieldy character, taking advantage of which the natives will dive beneath them and stab them with knives in vulnerable parts. The huntsman aims at their eyes as being the nearest approach to their brains. Mungo Park relates that one of his guides across the river Gambia was suddenly seized by a Crocodile and pulled under the water; upon which the negro thrust his fingers into the animal's eyes with such violence that it quitted its hold, but seizing him again, he resorted to the same expedient and with more success, as it again released him, appeared stupified, and then swam down the river. This man reached the bank bleeding very much, with long and deep wounds in his thighs, which incapacitated him for travel for six days. The crocodile lays an enormous number of eggs on the banks of its native rivers, but most of these are prevented from maturing by the birds and animals which prey upon them. Mrs. Bowdich tells an amusing story of a merchant who packed some crocodiles' eggs in sand for shipment to England and placed the barrel containing them with other goods in his warehouse. Strange and unaccountable 
noises, attracted attention to the spot, when it was discovered that the eggs had become hatched and the young crocodiles were quite ready to assume the responsibilities of life. The natives fled in terror, and the merchant had to take speedy measures for destroying his unexpected brood. Some species of the crocodile have been tamed or partially so, the sacred crocodiles being among these. Accustomed to be fed regularly by the same hands they gradually become familiar with their priestly attendants, and to some extent obedient to their commands. Mungo Park says:- "The crocodiles of the Congo appear to be of a smaller species, and not so numerous as those at Old Calabar, where they continually float past the shipping like large grey pieces of timber, and are so bold that they frequently seize people in the small canoes. In Old Calabar river, I once observed a crocodile swimming with a large cat-fish in its mouth to the opposite shore. It held the fish by the head, whilst the body was thrown into a perpendicular position. I watched it with the spy-glass until it had dragged the fish upon the mud bank, and commenced its meal."

The Alligator. The Alligator of which there are some ten or twelve species known, is found exclusively in America. The Mississippi Alligator is one of the most familiar of these. The Alligator is smaller than the crocodile, which it much resembles in form and habit, though specimens have been met with which measure twenty-two feet in length. The Alligator is naturally most abundant in tropical regions. Captain Brown says: "In the height of the dry season in torrid regions all animated nature pants with consuming thirst. A party of wood cutters, English and Irish, went on one occasion to hunt in the neighbourhood of a lake called Pies Pond in Beef Island, one of the smaller islands of the Bay of Campeachy. To this pond the wild cattle repaired in herds to drink, and here the hunters. lay in wait for them. The chase had been prosecuted with great success 
for a week, when an Irishman of the party going into the water during the day, stumbled upon an alligator, which seized him by the knee. His cries alarmed his companions, who fearing he had been seized by the Spaniards, to whom the island belonged, instead of affording assistance, fled from the huts which they had erected. The Irishman seeing no appearance of help, with happy presence of mind (a quality which the natives of that country possess in an eminent degree) quietly waited till the alligator loosened his teeth to take a new and surer hold; and when it did so, snatched away his knee, interposing the butt-end of his gun in its stead, which the animal seized so firmly that it was jerked out of the man's hand and carried off. He then crawled up a neighbouring tree, again shouting after his comrades, who now found courage to return." Mr. Waterton in his "Wanderings" says, "One Sunday evening, some years ago, as I was walking with Don Felipe de Ynciarte, governor of Augustura, on the bank of the Oroönque, 'Stop here a minute or two, Don Carlos,' said he to me, 'while I recount a sad accident. One fine evening last year, as the people of Augustura were sauntering up and down here, in the Alameda, I was within twenty yards of this place, when I saw a large Cayman rush out of the river, seize a man, and carry him down, before any one had power to assist him. The screams of the poor fellow were terrible as the Cayman was running off with him; he plunged in the river with his prey; we instantly lost sight of him, and never saw or heard him more." "

A Tame That the Alligator is amenable to kindness is Alligator. shown by the following account of a tame specimen, which we quote from $\mathrm{Mr}$. Jesse. He says, "The most singular instance of attachment between two animals, whose nature and habits were most opposite, was related to me by a person on whose veracity I can place the greatest reliance. Before he took up his abode at Hamoden-court, he had 
resided for nine years in the American States, where he superintended the execution of some extensive works for the American government. One of these works consisted in the erection of a beacon in a swamp in one of the rivers, where he caught a young alligator. This animal he made so perfectly tame, that it followed him about the house like a dog, scrambling up the stairs after him, and showing much affection and docility. Its great favourite, however, was a cat, and the friendship was mutual. When the cat was reposing herself before the fire (this was at New York), the alligator would lay himself down, place his head upon the cat, and in this attitude go to sleep. If the cat was absent, the alligator was restless; but he always appeared happy when the cat was near him. The only instance in which he showed any ferocity was in attacking a fox, which was tied up in the yard. Probably, however, the fox resented some playful advances, which the other had made, and thus called forth the anger of the alligator. In attacking the fox he did not make use of his mouth, but beat him with so much severity with his tail, that had not the chain which confined the fox broken, he would probably have killed him. The alligator was fed on raw flesh, and sometimes with milk, for which he showed great fondness. In cold weather he was shut up in a box, with wool in it; but having been forgotten one frosty night, he was found dead in the morning."

ORDER III. Order III consists of a large reptile belongHatteria

Punctata. ing to New Zealand which for anatomical reasons cannot be classed either with the Crocodiles or the Lizards. It is rare if not almost extinct, but a specimen may be seen in the Natural History Museum.

ORDER IV. The lizards form an exceedingly numerous

The Lizards, order. There are many hundreds of different species, large and small, of which we can only refer to the Chameleon, the Iguana, the common Lizard, and the Monitor. The Chameleon. The Chameleon Family belongs to Africa, 
the common variety being otherwise found in central Asia and Ceylon. There are several genera and numerous species. They live on insects and possess tongues of unusual length, furnished with a sticky mucus, which they protrude and retract with such rapidity and certainty of aim that insects are caught and conveyed to the mouth with a speed the eye cannot follow. The characteristic for which they are most famous is that of changing their colour, a power which has doubtless been much exaggerated, but which no less surely exists. Mrs. Bowdich describes some she had in her possession; she says, "Mine became green and yellow, assumed lighter and brighter lines, but I could not see the bright blue or red substances on which I put them reflected in their skins." According to M. D'Obsonville, who is quoted by Mrs. Bowdich, the original colour is green, the shades of which vary according to circumstances. When at liberty, and in health, it assumes gradations of brown, red, or light grey; when well-fed and in the open air, if provoked, it becomes a blue-green; but when feeble, or deprived of free air, the prevailing tint is yellow-green. If surrounded and teased or if one of its own species comes near, it exhibits all three tints of green. If dying, especially of hunger, yellow first predominates; and when dead, it is the colour of dead leaves.

The Iguana. The Common Iguana, which sometimes attains to a length of five feet, belongs to South America. It is a singular-looking animal, but is much esteemed as an article of food, its flesh resembling that of chickens. When taken young it may be tamed by kindness, but otherwise it is fierce when attacked, and its bite is very severe. It is said that the natives of the Bahama Islands, who subsist largely on the Iguana, sew up their mouths to prevent their biting when they wish to keep them alive for a time.

The Common The Common Lizard and the Sand Lizard are Lizard. the varieties found in England. The Common 
Lizard is the smaller of the two, measuring about six inches, the Sand Lizard sometimes attaining to double that length. The former frequents green and sunny banks, and is so rapid in its movements when disturbed that it is sometimes mistaken for a viper. The latter, which frequents sandy heaths and lives in burrows, assimilates to the colour of its surroundings.

The Monitor. The Monitor is the largest of the Lizards, sometimes measuring as much as six feet in length. The largest of these frequents the Nile, and is known as the Nile Monitor, from the habit attributed to it of signalling the presence of crocodiles by a peculiar whistling sound. Dr. Abel Smith says, "It is usually met with in rocky precipices, or on low, stony hills, and when surprised, seeks concealment in the chinks of the former, or in the irregular cavities of the latter; and when any projections exist upon the surface of the rocks or stones, it clasps them so firmly with its toes, that it becomes a task of no small difficulty to dislodge it, even though it can be easily reached. Under such circumstances the strength of no one man is able to withdraw a full-grown individual; and I have seen two persons required to pull a specimen out of a position it had attained, even with the assistance of a rope fixed in front of its hinder legs. The moment it was dislodged it flew with fury at its enemies, who by flight only saved themselves from being bitten. After it was killed, it was discovered that the points of all the nails had been broken previously, or at the moment it lost its hold. It feeds upon frogs, crabs, and small quadrupeds, and, from its partiality to the two former, it is often found among rocks near to springs or running streams, which fact having been observed by the natives, has led them to regard it as sacred, and not to be injured without danger of drought."

ORDER IV. There are hundreds of species of snakes dis-

snakes. tributed in different parts of the world, of which we can only select a few of the better known for present pur- 
poses. These are the Viper, the Rattlesnake, the Cobra, the Boa Constrictor.

The Viper. The Viper is found throughout Europe and is the only venomous reptile known in England. It feeds on frogs, lizards, mice and other small animals, but like many of the snake kind often gorges itself and falls a victim to its own rapacity. A Viper mentioned in the "Magazine of Natural Histery" swallowed a lizard almost as large as itself, with the result that one of the lizard's legs protruded through its side. Another Viper came into the possession of Professor Bell, which had lost its life through attempting to swallow a mouse which was too big for it, the skin of its neck being so distended as to burst in several places. The sting of the Viper, though venomous, is not nearly so fatal as is commonly supposed. The simplest remedy is suction, a fomentation, and the application of oil. Vipers are sometimes caught by the sudden seizure of the hand, at the neck, whereupon the creature opens its mouth to bite its captor who cuts off its fangs with a pair of scissors.

The Viper

and its

Young.

"On August 4th, I776,"' says Gilbert White, "we surprised a large viper, which seemed very heavy and bloated, as it lay in the grass basking in the sun. When we came to cut it up, we found that the abdomen was crowded with young, fifteen in number; the shortest of which measured full seven inches, and were about the size of full-grown earth-worms. This little fry issued into the world with the true viper-spirit about them, showing great alertness as soon as disengaged from the belly of the dam : they twisted and wriggled about, and set themselves up, and gaped very wide when touched with a stick, showing manifest tokens of menace and defiance, though as yet they had no manner of fangs that we could find, even with the help of our glasses. To a thinking mind nothing is more wonderful than that early instinct which impresses young animals with a notion of the situation of their natural weapons, 
and of using them properly in their own defence, even before those weapons subsist' or are formed. Thus a young cock will spar at his adversary before his spurs are grown; and a calf or a lamb will push with their heads before their horns are sprouted."

The Rattle. The Rattlesnake belongs to America, and many snake. exaggerated stories are current concerning it. At certain seasons it is very fierce and its bite at all times very dangerous, but in the ordinary way it will not attack anything but the animals it feeds upon, unless molested. It has been tamed and kept in cages, one in the possession of Mr. Pierce making friends with a toad which was introduced to its cage for the purposes of food, and allowed it to take many liberties.

The Sting "After the death of this snake," says Mr. of the Pierce, "I examined his fangs; they were sharp Rattle- like a sickle; a duct led from the reservoir of snake. poison at the bottom of the tooth quite through its whole length, and terminated just by the point, which was exceedingly sharp. Thus, when the fang is darted out it makes the puncture, and simultaneously the poison flows through the duct, and is deposited in the very bottom of the wound. As this rarely fails to touch a blood-vessel, the venom is thus instantly issued into the system, and without delay, commences the march of death through every vein and artery." Mr. Smith in the Philosophical Transactions (1848) says :"If a venomous serpent be made repeatedly to inflict wounds, without allowing sufficiently long intervals for it to recover its powers, each successive bite becomes less and less effective. A gentleman who had a rattlesnake in a cage, put a rat in with it; it immediately struck the rat, which died in two minutes. Another rat was then introduced, which ran as far as it could from the snake, with cries of distress. In half an hour, during which time the snake showed no hostility, on being irritated, it struck the rat, which died in twenty minutes. A third, and remarkably large rat, was then thrust into the 
cage, which showed no terror of the snake, and the snake took no notice of the rat; the gentleman, after watching them for the whole evening, went to bed, and when he inspected the cage the next morning, the snake was dead, and the muscular part of its back eaten by the rat."

The rattle consists of a number of horny joints which when shaken produce the sound by which it is known, and which gives notice of the proximity of the snake.

The Black

"The black snake of Central America," says Snakeand the Mr. Byam, " is a deadly enemy to the rattlesnake; Rattlesnake. it is next in size to the boa, but much more agile; very vicious and ill-tempered, but not poisonous ; it measures from nine to ten feet, and whenever they meet a pitched battle ensues, which, if tolerably equal in size, ends in favour of the black snake. It is not known whether they bite each other, but, at all events, the poison of the venomous serpent has no effect upon his adversary, although a rattlesnake bit itself one day, and died of the wound. A black and a rattlesnake were each descending opposite banks to drink at a stream a yard broad; the black fellow sprang over the stream, and they instantly joined in conflict. They twined together, and the black snake had evidently most muscular power, so that in half an hour the rattlesnake was dead, and the black snake swallowed him, gliding into the thicket, double the size he was when he came out of it."

The Cobra. The Cobra is one of the most venomous of the snakes of the East. It is common all over India and Ceylon and the Islands of the Archipelago. It attains to a length of five or six feet, and feeds on birds, small animals, lizards, frogs, toads, and fishes, in the pursuit of which it will ascend trees and swim the sea. Notwithstanding its dangerous character, the Cobra is the chosen subject of the Indian snake-charmer, who keeps it in a basket, until the time for the performance and then allows it to creep out to the sounds of a native fife, upon hearing which the Cobra immediately expands its beauti- 
ful though threatening hood, erects its neck, and commences a series of undulating movements, which are continued until the sound of the fife ceases, when the snake instantly drops, and is replaced in its basket by its master.

Snake

" One morning, as I sat at breakfast," says a Charming. writer in the Penny Magazine, "I heard a loud noise and shouting among my palankeen bearers. On enquiry, I learned that they had seen a large hooded snake, and were trying to kill it. I immediately went out, and saw the snake creeping up a very high green mound, whence it escaped into a hole, in an old wall of an ancient fortification; the men were armed with their sticks, which they always carry in their hands, and had attempted in vain to kill the reptile, which had eluded their pursuit, and in his hole had coiled himself up securely, whilst we could see his bright eyes shining. I had often desired to ascertain the truth of the report, as to the effect of music upon snakes. I therefore enquired for a snakecatcher. There was one about three miles off, and I accordingly sent for him, keeping a strict watch over the snake, which never attempted to escape, whilst we, his enemies, were in sight. About an hour elapsed, when my messengers returned, bringing a snake-catcher. This man wore no covering on his head, nor any on his person, excepting a small piece of cloth round his loins; he had in his hands two baskets, one containing tame snakes, the other empty; these, and his musical pipe, were the only things he had with him. I made the snake-catcher leave his two baskets on the ground, at some distance, while he ascended the mound with his pipe alone. He began to play ; at the sound of music the snake came gradually and slowly out of his hole. When he was entirely within reach, the snake-catcher seized him dexterously by the tail, and held him thus at arm's length, while the snake, enraged, darted his head in all directions, but in vain ; thus suspended, he has not the power to round himself, so as to seize hold of his tormentor. He exhausted himself in vain exertions; when 
the snake-catcher descended the bank, dropped him into the empty basket, and closed the lid, he then began to play, and after a short time raising the lid of the basket, the snake darted about wildly, and attempted to escape ; the lid was shut down again quickly, the music always playing. This was repeated two or three times ; and, in a very short interval, the lid being again raised, the snake sat on his tail, opened his hood, and danced quite as quietly as the tame snakes in the other basket, nor did he again attempt to escape."

The Cobra as A gentleman in India once visited a neighbourCompanion ing station for the purpose of taking part in a of the Bath. cricket match, and was hospitably entertained. $\mathrm{He}$ was put up in a large tent, accompanied by his wife. After the day's play, at dusk, he went between the canvas walls of the tent where his bath was ready. Touching the bath-tub, were placed two large earthenware jars, full of cold water, and next to them was a brass basin, also containing water, on a stand; the light was burning in the centre of the tent so that between the canvas walls was darkness. He stepped into the tub, and finding the water too hot, bent down to take up one of the cold water jars, but something induced him instinctively to refrain. He stayed his hand, at the same time calling out to his wife to bring a light, which she did when, to his horror, he saw a large cobra coiled round the mouth of the jar, within a foot of his naked legs. The sensation can be imagined. To move was probably death, to stand still required nerve. Experience and courage decided the point, and fixing his eye on the reptile, he quietly told his wife to put down the light on the ground and get him a stick. The wife, a sensible creature, obeyed, leaving her lord in the agonies of suspense as to what the snake's next move would be. This was soon settled by the reptile uncoiling itself and gliding up the chillumchee stand on to the basin, from which it commenced drinking. By this time the stick was gently put into the bather's hand, who with a well-directed blow cut the snake in half against 
the edge of the copper basin, thus putting a full stop to a thrilling period.

A Night with I was on a visit during the rainy season, a few a Cobra. years ago, says a recent writer, when I slept upon an iron bedstead which had two lots of bedding on it. The first night I awoke, as I thought with a horrible nightmare, feeling the cold slimy body of a snake gliding over my person, and imagining myself in the regions described in Milton's Paradise Lost, and so wondrously drawn by Doré. I was bathed in perspiration, and trembled all over till daylight brought relief, and I convinced myself it must have been merely a nightmare. But the next night I again awoke in terror, feeling the same awful sensation of a cold, clammy body gliding gently along my side, and passing with a wriggle over my body ; terror preventing me moving. Whether I fainted or again fell asleep I have never been able to decide, but at daylight I fled from the room and sat cowering in the verandah, in a state of mind bordering on insanity. My hostess was informed of my state, and got me round with a glass of wine. Nothing could induce me to re-enter my bedroom. The bearer and other domestics were sent for, and headed by the mistress of the house, inspected the bed by removing the sheets. Nothing was to be seen till one of the servants brushed his leg against something soft and cold, and looked down at the junction of the two beddings; he saw the end of a dark-coloured tail. A howl from him scattered the servants and made me imagine the snake was about to attack me. The valiant servants again assembled, and with sticks entered the bedroom and poked off the upper bedding, revealing a large hooded cobra coiled in the centre, which was eventually despatched by blows.

An Unpleas.

A soldier in a regiment stationed at $\mathrm{C}$ ant Bedfellow. was, for disorderly conduct, condemned to pass the night in one of the cells. Just as he was going to sleep he was startled by hearing a noise, which he knew could only 
be occasioned by a snake. Instead of jumping up and calling to the sentinel for help, and perhaps treading on the snake and being bitten by it, he lay perfectly still, knowing that unless disturbed the snake would not hurt him. Presently the snake drew its cold slimy body over his bare feet. There are few persons who, in a similar condition, would not have drawn up their legs with a start, but our hero did not even move. Soon the snake began to crawl over his body and even passed over his face. The poor soldier hardly dared to breathe. At last the reptile coiled itself under his pillow, and when day broke our soldier, seizing the stone with which he ought to have blocked up the hole by which the snake entered, crushed it to death. On being examined, the reptile proved to be of a kind whose bite is almost invariably fatal.

The Boa The Boa Constrictor is one of the largest of the Constrictor. snake kind. It is not venomous, but is possessed of enormous strength which it shows by coiling itself round the object of its attack and crushing it into a shapeless mass. It belongs to tropical America and feeds on birds, and animals of all kinds, not hesitating to attack even the larger quadrupeds. The following account from the pen of Mr. Byam will give an idea of the way in which these monsters dispose of their prey.

The Boa and An Englishman and an Indian, travelling toits Prey. gether through a thick forest, heard a noise like the cry of a child in great pain. Pulling out their pistols, and tying up their horses, they proceeded to the spot, and there saw a boa crushing a young roebuck with short horns. It had wound itself twice round its prey, just behind the shoulders, one coil lying on the other to increase the weight, and its teeth were fastened on the back of the deer's head. The tail was twisted twice round a young tree close by. It was too busy to observe the strangers; and the Englishman wished to attack it, and save the deer; but the Indian walked off very gently, and made signs to him to follow. When they had regained 
their horses, the Indian said it would have been madness to have fought with the irritated animal, and they went their way. This was seven in the morning, and they marked the spot by notching the trees. At four in the afternoon they again passed that way, and found the boa lying straight upon the ground; one of the horns of the roebuck sticking out of a corner of the mouth, and the other looking as if it would perforate the neck of the snake; the tail was still coiled round the tree, and the middle of the body looked like a nine-gallon cask. A few blows of the hunting sword about the tail finished the monster; but when attacked, it tried to throw up the deer." The boa has been known to measure upwards of twenty-five feet, though commonly not exceeding eighteen feet.

The Boa's Captain Heyland thus describes a boa which

Appetite. was in his possession for some time :- "The animal was brought to me early in January, and did not taste food from that time until the July following. During this period he generally drank a quart of water daily. The man who brought him stated, that he had been seen to eat a hog deer the day before he was taken. He was allowed to be at liberty in the grounds about my house. One evening early in July, hearing a noise, I went out, and discovered that the snake had left his harbour, under the boards of a stable where he generally lay; and having entered a small shed in which some fowls were roosting, had swept eleven from the perch, and destroyed them by pressing them between his folds. Then taking them one by one, head foremost into his mouth, swallowed the whole down in twenty minutes. The largest animal that he ate while in my possession was a calf, which he killed and gorged in two hours and twenty minutes. He never attacked dogs, cats, or pigs. Of these last, indeed, he seemed to be in dread, for, whenever one was presented to him, he retired to a corner, and coiled himself up, with his head undermost. If fed with animals not larger than a duck, he ate readily every day; but after the meal of a goat, refused food for a month." 
A Terrible Not many years ago, says a writer in "Chums," Boa. a boa escaped from a menagerie at Grenoble, and disappeared without leaving a trace. A few days afterwards a certain Monsieur Flisson went on a visit to Beauregard along with a friend, who accompanied him on an excursion among the romantic hills and rocks in that part of the country. At a particularly interesting spot he tarried behind his friend, and, in order to enjoy the glorious prospect, sat down on what appeared to be a stone covered with soft moss. It was eight o'clock in the evening, and M. Flisson, though shortsighted, was a man of prodigious strength. This was lucky for him, for the stone now began to move under him, stretched itself out with the elasticity of a spring, and lifted him several feet from the ground. M. Flisson had sat down on the boa. Before he had time to recover his presence of mind, he felt himself rolling downwards. The serpent had curled his tail round a tree-trunk, and Flisson held its head firmly grasped between his hands. A strange and terrible struggle ensued. The boa, securely fastened to the tree, pulled upwards, and Flisson, still clinging with herculean strength to the head of the creature, found himself at last swinging over a precipice of about seventy feet in depth, as though suspended by a rope. In this terrible situation he remained ten minutes, until his friend, with the assistance of a few countrymen, came to his relief.

A Narrow Mr. Byam's book contains many interesting Fscape. anecdotes of the experiences of travellers of which the following snake story is one.

" Two travellers passed a hillock in a marsh, and heard some groans proceeding from a man on the top of it. Earnestly beckoned to approach, they at first hesitated, thinking it might be a contrivance to entice them into danger. They, however, went near, and the man told them that, while asleep, a snake had crept up his loose drawers, and was then lying on his stomach, and from what he had seen of it, he believed it to be a Coral-snake, one of the deadliest of the western serpents. 
He had nothing on but his drawers and a short cloak. The travellers saw the form of the snake under the drawers; they dismounted, put on thick gloves, took a pair of scissors, cut very carefully through the drawers till they came to the head of the animal, still fast asleep, and then one of them seized it by the neck, and so released the poor man. It was nearly three feet long, as thick as a walking-stick, coral-red in colour, with yellow rings. The poor man said he had passed two or three hours in that dangerous situation, which appeared as long as weeks, and had called to two or three passers-by, who had all avoided him, from the supposition that it was the decoy of a marauding Indian. He was completely unmanned, and his strength was prostrated by his apprehensions." 


\title{
NATURAL HISTORY IN ANECDOTE.
}

\section{VERTEBRATA.}

\author{
C LASS IV-BATRACH IA.
}

The Class IV of the Vertebrata comprises the BatraBatrachia. chia which are divided into three orders : I Pseudophidia, II Urodela, III Anura. The first order comprises the limbless worm-like reptiles of the genus Cæcilia of Africa and South America; the second includes the Newts and the Salamanders; the third the Frogs and the Toads. Leaving the first two orders, we devote a few lines to the third, dealing with the Toad, the Common Frog and the Tree Frog. The members of this order are singular for the extraordinary changes through which they pass between birth and maturity. As Tadpoles, in which form they first reach life, they have thick black legless bodies ending in tapering tails, and are provided with the fishlike anatomy necessary to an aquatic existence. In the process of development they completely change both in internal arrangement and external appearance. The gills are exchanged for lungs, the legs supersede the tail and the internal system undergoes corresponding change. In the end the animal becomes semi-aquatic, capable of living under water for some time, but compelled to come to the surface for air at intervals; and also of living out of the water altogether in such places as afford sufficient moisture, damp being as necessary to their comfort as food and air. They hybernate in the winter and propagate in the spring; and in times of drought burrow into the earth and remain lethargic until rain falls. They feed on 
insects and slugs for which they have a voracious appetite. Their tongues, which like those of the chameleon and other insect eaters, are furnished with a sticky mucus to which insects adhere, - when in repose, turn inwards towards the throat and the act of catching flies and other insects is simply that of flapping the tongue out and in again, an act performed with such rapidity as to almost escape observation.

The Common The toad is found in all temperate and torrid

Toad. climes. It hides in damp secluded places during the day, emerging in search of food at night, or after the fall of rain. Though voracious in its appetite, it can accommodate itself to circumstances and can subsist with little food if its abode be damp. Failing food and damp, it has yet another resource, namely that of sleep, or torpor, in which condition it can lay by and wait for better times. Under such circumstances the toad naturally lives a long life and survives conditions usually fatal. The voracity of the toad is attested by the following incident furnished by Captain Brown. "A gentleman who resides at Keswick, Cumberland, one evening in the latter end of July, observed a rustling among the strawberries in his garden, and on examining what it was, found that a toad had just seized a field-mouse, which had got on the toad's back, scratching and biting to get released, but in vain. The toad kept his hold, and as the strength of the mouse failed, he gradually drew the unfortunate little animal into his mouth, and gorged him."

Tame Tozds. The toad may be easily tamed. Mr. Wood tells of one which lived with a family for years and was in the habit of supping on a piece of sugar. The story of the Duke of Wellington and the tame toad deserves telling in this connection. The Duke of Wellington was one day taking his usual country walk, when he heard a cry of distress. $\mathrm{He}$ walked to the spot, and found a chubby, rosyfaced boy lying on the ground, and bending his head over a tame toad, and crying as if his little heart would break. Enquiry elicited the 
fact that the boy was about to be sent to boarding school and that he was afraid the toad lacking his attention would die in his absence. The duke promised to look after the toad and apprise the boy from time to time of its condition. During the time he was at school he received five letters couched in the following terms:-Strathfieldsaye, July 27, 1837. "Field Marshal the Duke of Wellington is happy to inform William Harries that his toad is alive and well." When the boy returned for his Christmas holidays, the toad was as the duke said, "Alive and well," but, in accordance with the usual habits of these animals, he was in his winter's sleep, in which he remained until spring and genial weather brought him from his well-guarded hole in the ground.

The

The Common Frog (Rana Temporaria) is now Common found all over the British Isles. Formerly unFrog. known in Ireland it was introduced there about the year I700 and has since spread all over the country. The frog is more sociable than the toad and is often seen and heard in large numbers; his habits however are very similar and his mode of seizing his prey the same. The Edible Frog belongs to Europe, where it is used as an article of food and is not found in England. The Bull Frog is an Indian variety and attains to a great size. The American Bull Frog is also an interesting species.

The

Mr. Jesse gives the following illustration of the Ingenuity of ingenuity of the Frog: "I may mention a curithe Frog. ous observation made in regard to some frogs that had fallen down a small area, which gave light to one of the windows of my house. The top of the area being on a level with the ground, was covered with some iron bars, through which the frogs fell. During dry and warm weather, when they could not absorb much moisture, I observed them to appear almost torpid ; but when it rained they became impatient of their confinement, and endeavoured to make their escape, which they did in the following manner. The wall of the 
area was about five feet in height, and plastered and whitewashed, as smooth as the ceiling of a room. Upon this surface the frogs soon found that their claws would render them little or no assistance; they therefore contracted their large feet, so as to make a hollow in the centre, and by means of the moisture which they had imbibed in consequence of the rain, they contrived to produce a vacuum, so that by the pressure of the air on the extended feet (in the same way that we see boys take up a stone by means of a piece of wet leather fastened to a string), they ascended the wall and made their escape. This happened constantly in the course of three years."

The Tree The Tree Frog of which there are numerous Frog. varieties belongs to both East and West occurring in China and Japan as well as in North and South America. It is not found in England. Mr. Gosse says : "They are very numerous in the damp woods of tropical America, and reside by day in the tofts of those parasitical plants, which form reservoirs for rain-water. The under-surface of their bodies is very different to that of the terrestrial species; for the skin, instead of being smooth, is covered with granular glands, pierced by numerous pores, through which the dew or rain, spread on the surface of the leaves, is rapidly absorbed into the system, and reserved to supply the moisture needful for cutaneous respiration. The males make the woods resound throughout the night with their various cries, and, mingled with the shrill chirping of insects, quite banish sleep from the stranger's eyes." 


\section{NATURAL HISTORY IN ANECDOTE.}

\section{VERTEBRATA.}

\section{CLASS V-P I S ES.}

Fishes. We now come to the fifth and last class of the Vertebrata, a class so large that it is impossible to deal adequately with it in a single volume of ordinary size, much less in a single section of one treating of the whole of the vertebrates. There are said to be 10,000 species, so that a book which devoted one page to each would make an enormous volume. All that can be done here is to deal with a few of the better known species, as far as possible selecting types of orders without attempting to follow closely any classification. Günther divides the Fishes into six sub-classes, which are further arranged in thirteen orders. The first of these orders includes the Sticklebacks, the Perches, the Mullets, the Gurnards, the Mackerel and the Swordfish besides others. Of these we can deal with but two or three.

The The Stickleback is associated with the earliest 8ticklebacks. efforts of the youthful angler, and most of us can remember capturing specimens of some fresh-water variety, in the days of childhood, and carrying them home in triumph in a bottle. There are a number of species of the stickleback, some living in fresh water and some being marine. They are extremely voracious and it is a good job for a large number of other living things that they are no bigger than they are. They are also very pugnacious and fight among themselves with great determination. The Stickleback is about an inch and a half 
, 
in length and is furnished with spines which it uses with great effect when fighting with its enemies.

The Stickle- Mr. John Stark who experimented with some back and the sticklebacks and leeches some years ago gives the

Leech. following description of his experiences.

"On putting the leeches into the water, the stickleback darted round the tumbler with lively motions till it found a leech detached, and in a proper situation for being seized. When the leech was very small, say about half an inch in length, it was often swallowed at once before it reached the bottom of the vessel, but when a larger one, about an inch, or an inch and a half in length in its expanded state, was put in, and had fastened itself by its mouth to the glass, the efforts of the stickleback to seize and tear it from its hold, were incessant, and never failed to succeed. It darted at the loose extremity, or, when both ends were fastened, at the curve in its middle, seized it in its mouth, rose to near the surface, and after a hearty shake (such as a dog would give a rat) let it drop. The leech, who evidently wished to avoid its enemy upon its release again, attached itself by its mouth to the glass; but again and again the attack was repeated, till the poor leech became exhausted, and ceased to attempt holding itself by its disc. The stickleback then seized it by the head in a proper position for swallowing, and after a few gulps the leech disappeared. The flattened leech being of an oval form, and having a hard skin, was not attacked, unless when very young, and small; and leeches of the other species when pretty well grown, or larger than himself when expanded, were killed in the manner above mentioned, but not swallowed. In one of his attempts to seize a leech, the stickleback having got it by the tail, the animal curled back and fixed its disc upon his snout. The efforts of the stickleback to rid himself of this encumbrance were amusing. He let go his hold of the leech, which then hung over his mouth, and darting at the bottom and sides of the glass with all his strength, endeavoured to rub 
off this tantalizing morsel. This lasted for nearly a minute, when at last he got rid of the leech by rubbing his back upon the bottom of the vessel. The leech, perfectly aware of the company he was in, no sooner loosed his hold, than he attempted to wriggle away from his devourer; but before he had reached mid-way up the tumbler, the stickleback had turned and finished the contest by swallowing him up."

The The mackerel is one of the most useful as well Mackerel. as one of the most beautiful of familiar fishes. It measures from twelve to twenty inches and weighs from one and a half to two or three pounds. It is elegant of form and brilliant of colour, as well as agreeable as an article of food. Mackerel visit the coast of England in vast shoals at certain seasons, but retire to deep seas for the winter. They are exceedingly voracious, and prey upon the herrings; Captain Brown tells a story of a number of mackerel fastening on to a sailor who had plunged into their midst for a bath. The man was rescued by his comrades, but he died soon after from loss of blood.

The The sword-fish is a formidable member of this sword-fish. order. It is found in the Mediterranean, and the Atlantic, and sometimes visits the English coast. It has been known to measure ten feet or more without the sword, with which it attains even to a length of fifteen feet. It attacks other large fish and is a great enemy to the whale, which it charges with great force and destructive effect. It is said sometimes to mistake the hull of a ship for the body of a Whale and to charge it accordingly, with the result that it leaves its sword fixed in the ship's timbers as the bee leaves its sting in human flesh. The sword of this fish is formed by the elongation of its upper jaw and some idea of the force with which it can be used may be gained from the fact that one found in the hull of a ship at Liverpool and described by Scoresby had penetrated a sheet of copper, an oak plank two and a half inches in thickness, a solid oak timber of seven and a half inches, and 
another plank also of two inches. "The position of the bone was at the distance of four feet horizontally from the stern, and two feet below the surface of the water when the vessel was afloat. Hence, it appeared, that when the ship had been in rapid progress through the water, she had been met with and struck by a sword-fish advancing in an opposite direction, by the shock of which, or by the action of the water forced past the body of the animal by the vessel's progress, the snout had been broken off and detached. The blow, though it must have been singularly forcible, was not observed by any person in the ship. Had the bone been withdrawn, the vessel would probably have foundered." Mr. Wood says in one instance, a sword-fish attacking a whaling-ship, drove its weapon " through the copper sheathing, an inchboard sheathing, a three-inch plank of hard wood, the solid white oak timber of the ship twelve inches thick, through another two-and-a-half inch hard oak ceiling plank, and lastly, perforated the head of an oilcask, where it still remained immovably fixed, so that not a single drop of oil escaped."

The Cod. The third order of Dr. Günther's classification includes many of the more familiar fishes. Here we find the Cod, the Haddock, the Place, the Flounder, the Halibut, the Turbot, the Brill and the Sole. Of these we will take the Cod as representative. The Cod is one of the most prolific of fish. Enormous quantities are caught and consumed every year and yet the number seems to increase rather than decrease. This is accounted for by the fact, that the spawn of one fish will sometimes contain nine millions of eggs. The Cod frequents the deep seas of the temperate and colder climes, not being found in any quantities north of Iceland, or South of Gibraltar. They are found chiefly in the Northern Atlantic, where extensive fisheries are carried on, but they are also caught in the Forth of Firth at the mouth of which some of the best are taken. The Cod grows very rapidly and often to a great size. One is said to have been caught off Scarborough many years 
ago which weighed seventy-eight pounds and measured five feet eight inches in length. They feed on herrings, sprats, mollusca, worms, and small shell fish, are very voracious, and have excellent digestions. Captain Brown killed one at Killough, Co. Down, Ireland, in which he found upward of fifty small crabs, and other testaceous and crustaceous animals. The Cod fisheries find employment for a large number of people and are a great source of profit. The flesh is highly valued as an article of diet, and the liver for the properties of the oil which it produces, while other parts are used for various purposes.

The Salmon. In the Fourth order of Dr. Günther's classification we find the Salmon, the Trout, the Pike, the Flying Fish, the Carp, the Roach, the Chub, the Herring, the Sardine, the Anchovy, the Gymnotus and the Eel, besides other fish. Of these the Salmon takes easy precedence. Izaak Walton called it " the King of fresh-water fish," and many have accorded it the first place among its kind for the delicacy of its flavour. It is of migratory habits, leaving the sea in the autumn and ascending rivers for the purpose of depositing its spawn, and returning to the sea in the spring. In seeking suitable places for its purpose the salmon brooks no obstacle, leaping with great vigour the rapids and falls that impede its course even though they may sometimes exceed eight or ten feet in height. Curving the body until it forms a circular spring, it strikes the water with great force, throwing itself forward and thus lifting itself over rocks and weirs. In the shallow gravelly pools which they find towards the source of rivers, Salmon form hollows in which they spawn, covering it up with the loose sand they excavate in the process. The eggs deposited in the later months of the autumn are hatched in the earlier months of Spring and by the end of May the whole of the young fish have followed their parents to the sea.

The Pike. The Pike,-fierce, strong, and voracious, holds his own in the rivers of both the old and the new Worlds. 
It has been known to attack a man when its retreat has been cut off ; to bite the legs of bathers, and to snap at the fingers of persons cooling their hands in the water; and when pressed with hunger, to fight an otter for the possession of a carp, which the latter had caught. Its strength and endurance have often been demonstrated in the destruction of strong tackle and in its power to survive, without apparent inconvenience with hooks and wires mingling with its anatomy. Captain Brown gives an instance of a pike being caught, which had a strong piece of twisted wire projecting from its side. It was in excellent condition, and on being opened, discovered in its stomach a double eel hook, much corroded, and attached to the protruding wire. Another pike when caught, in the river Ouse, was found in possession of a watch with a black ribbon and seals attached; property which it was afterwards discovered had belonged to a gentleman's servant who had been drowned. The pike has often been caught with portions of tackle broken from the line in former engagements hanging from the mouth. Its rapacity is extraordinary. Eight-hundred gudgeon are said to have been consumed in three weeks by eight pike of not more than five pounds weight each. "The appetite of one of my pike," says Mr. Jesse, "was almost insatiable. One morning I threw to him one after the other, five roach, each about four inches in length. He swallowed four of them, and kept the fifth in his mouth for about a quarter of an hour, when it also disappeared." The pike attains to large proportions and to a great age. When less than two pounds weight it is called a jack, but it has been known to attain to sixty or seventy pounds weight, and if all records be true, to more than a hundred years of age. Gesner mentions a pike caught in standing water at Heilbroon, in Suabia in 1497 which had a ring round its head with an inscription in Greek which ran somewhat as follows: "I am the first fish that was launched into this pond, and was thrown in by Frederick the Second, emperor of the Romans, on the fifth of October, 12zo," If 
this be true, the pike was two hundred and fifty-seven years old at the time of its capture, when it is said to have weighed three hundred and fifty pounds.

The Herring. Probably no living thing of its size is equal to the herring in its value to man. It visits the northern coasts of England and Scotland in vast shoals, of several miles in extent, in the autumn of the year, heralded by sea gulls and followed by dog-fish, both of whom take toll as it proceeds. The annual produce of these little fish is beyond all calculation. The Scotch fisheries are credited with the capture of over four hundred millions a year, while those of Norway can scarcely be much less successful. The Swedish fisheries are said to capture nearly double that number, to which must be added those taken by the English, Irish, Dutch, French, and German fisheries before the grand total can be reached. The enormous number of hands employed in these various fisheries, to say nothing of the capital invested in them, marks them out as one of the most important of European enterprises.

The Flying The Flying fish is about the size of a herring,

Fish. and is furnished with strong pectoral fins, almost the length of its body, by which it is able to spring out of the water and sustain itself for a time in the air. It has apparently no power of guiding itself, or of varying its altitude while in the lighter element, both the height and the course of its flight being determined by the direction and the force of its spring. Its ordinary flight is about three feet above the surface of the water, and of no very great distance or duration, but it has been known to fly as high as fourteen or fifteen feet, and even higher, and a distance of over two hundred yards. Flying fish often fall upon the decks of ships, where they are welcomed as affording a pleasant variety to the sailors' menu. They frequent warmer latitudes, but are sometimes seen off the English coast. They leave the sea to escape the larger fish which prey upon them, only too often, to fall a prey to the fowls of the air. 
Digitized by Microsofte 
The Eel. The Eel from its general resemblance to the snake is not usually a favourite when alive, however popular it may be with the palate, when served up with suitable accessories at table. It is however full of interest as a study, and shows many remarkable characteristics and traits. It migrates from the river to the sea in the Autumn to produce its young, thus reversing the order of procedure of the salmon. $\mathrm{Mr}$. Jesse, writing of these migrations as observed by him in the Thames many years ago, says: "An annual migration of young eels takes place in the river Thames in the month of May, and they have generally made their appearance at Kingston, in their way upwards, about the second week in that month. These young eels are about two inches in length, and they make their approach in one regular and undeviating column of about five inches in breadth, and as thick together as it is possible for them to be. As the procession generally lasts two or three days, and as they appear to move at the rate of nearly two miles and a half an hour, some idea may be formed of their enormous number. Sir Humphry Davy says, in his "Salmonia,"- "There are two migrations of eels, one from and the other to the sea ; the first in spring and summer, and the second in autumn, or early in winter. The first of very small eels, which are sometimes not more than two and a half inches long; the second of large eels, which sometimes are three or four feet long, and weigh from fifteen to twenty pounds. There is great reason to believe, that all eels found in fresh water are the results of the first migration; they appear in millions in April and May, and sometimes continue to rise as late as July, and the beginning of August. They feed, grow, and fatten in fresh water. In small rivers, they are seldom very large; but, in large deep lakes, they become as thick as a man's arm, or even leg; and all those of a considerable size attempt to return to the sea in October or November, probably when they experience the cold of the first autumnal rains." Mr. St. John thus describes some young 
Eels which he saw ascending the river Findhorn: "When they came to a fall, which they could not possibly ascend, they wriggled out of the water, and gliding along the rock, close to the edge, where the stone was constantly wet from the splashing and spray of the fall, they made their way up till they got above the difficulty, and then again slipping into the water, continued their course." The eel is voracious, and will leave the water in search of frogs and other food. It will attack, and appropriate, young ducks, and one is said to have been caught near Bootle with two rats in its stomach. The Conger Eel grows to a great size and attains great weight. It is said sometimes to measure eight or even ten feet, and to weigh a hundred pounds or even more. It is plentiful in the English Channel, and on the coast of Cornwall.

The The Gymnotus is the famous electric eel, and Gymnotus. like the Torpedo of the English Channel and the Mediterranean, has the ability of communicating a powerful electric shock. It belongs to the Amazon and other South American rivers, and their tributaries, and is well known to American Indians. Humboldt describes the shock produced by this creature, as exceeding in strength that of a large Leyden jar. Having imprudently placed his foot on one just taken from the water he received such a shock that he says, "I was affected the rest of the day with violent pains in the knees, and in almost every joint."

Catching the The following vivid description of a Gymnotus Gymnotus. hunt is given by Humboldt: "We at first wished to make our experiments in the house we inhabited at Cakabozo ; but the dread of the electrical shocks of the gymnoti is so exaggerated among the vulgar; that during three days we could not obtain one, though they are easily caught, and though we had promised the Indians two piastres for every strong and vigorous fish.

"Impatient of waiting, and having obtained very uncertain results from an electrical eel that had been brought to us 
alive, but much enfeebled, we repaired to the Cano de Bera, to make our experiments in the open air, on the borders of the water itself. We set off on the Igth of March for the village of Rastro de Abaxo, thence we were conducted to a stream, which, in the time of drought, forms a basin of muddy water, surrounded by fine trees. To catch the gymnoti with nets is very difficult, on account of the extreme agility of the fish, which bury themselves in the mud like serpents. We would not employ the barbasco, that is to say, the roots of Piscidea erythrina and Jacquinia armillaris, which, when thrown into the pool, intoxicate or benumb these animals. These means would have enfeebled the gymnoti; the Indians therefore told us, that they would ' fish with horses.' We found it difficult to form an idea of this extraordinary manner of fishing; but we soon saw our guides return from the Savannah, which they had been scouring for wild horses and mules. They brought about thirty with them, which they forced to enter the pool.

" The extraordinary noise caused by the horses' hoofs makes the fish issue from the mud, and excites them to combat. These yellowish and livid eels resemble large aquatic serpents, swim on the surface of the water, and crowd under the bellies of the horses and mules. A contest between animals of so different an organization furnishes a very striking spectacle. The Indians, provided with harpoons and long slender reeds, surround the pool closely; and some climb upon the trees, the branches of which extend horizontally over the surface of the water. By their wild cries, and the length of their reeds, they prevent the horses from running away and reaching the bank of the pool. The eels, stunned by the noise, defend themselves by the repeated discharge of their electric batteries. During a long time they seem to prove victorious. Several horses sink beneath the violence of the invisible strokés which they receive from all sides, in organs the most essential to life ; and stunned by the force and frequency of the shocks, disappear under the water. Others, panting, with their mane 
standing erect, and wild looks, expressing anguish, raise themselves and endeavour to flee from the storms by which they are overtaken. They are driven back by the Indians into the middle of the water; but a small number succeeds in eluding the active vigilance of the fishermen. These regain the shore, stumbling at every step, and stretch themselves on the sand, exhausted with fatigue, and their limbs benumbed by the electric shock of the gymnoti.

"In less than five minutes two horses were drowned. The eel, being five feet long, and pressing itself against the belly of the horses, makes a discharge along the whole extent of its electric organs. It attacks at once the heart, the intestines, and the plexus coeliacus of the abdominal nerves. It is natural, that the effect felt by the horses should be more powerful than that produced upon men by the touch of the same fish at any one of his extremities. The horses are probably not killed, but only stunned. They are drowned from the impossibility of rising from amid the prolonged struggle between the other horses and the eels.

"We had little doubt, that the fishing would terminate by killing successively all the animals engaged; but by degrees the impetuosity of this unequal combat diminished, and the wearied gymnoti dispersed. They require a long rest, and abundant nourishment, to repair what they have lost of galvanic force. The mules and horses appear less frightened; their manes are no longer bristled, and their eyes express less dread. The Indians assured us, that when the horses are made to run two days successively into the same pool, none are killed the second day. The gymnoti approach timidly the edge of the marsh, when they are taken by means of small harpoons fastened to long cords. When the cords are very dry, the Indians feel no shock in raising the fish into the air. In a few minutes we observed five eels, the greater part of which were but slightly wounded. Some were taken by the same means towards the evening. 
"The temperature of the water in which the gymnoti habitually live is about 86 degrees of Fahrenheit. Their electric force, it is said, diminishes in colder waters. The gymnotus is the largest of electrical fishes. I measured some that were from four feet to five feet three inches long; and the Indians assert, that they have seen them still larger. We found that a fish of three feet ten inches long weighed twelve pounds. The transverse diameter of the body was three inches five lines. The gymnoti of Cano de Bera are of a fine olive-green colour. The under part of the head is yellow, mingled with red. Two rows of small yellow spots are placed symmetrically along the back, from the head to the end of the tail. Every spot contains an excretory aperture. In consequence the skin of the animal is constantly covered with a mucous matter, which, as Volta has proved, conducts electricity twenty or thirty times better than pure water. It is somewhat remarkable, that no electrical fish yet discovered in the different parts of the world, is covered with scales.

"It would be rashness to expose ourselves to the first shocks of a very large and strongly irritated gymnotus. If by chance you receive a stroke before the fish is wounded, or wearied by a long pursuit, the pain and numbness are so violent, that it is impossible to describe the nature of the feeling they excite. I do not remember having ever received from the discharge of a large Leyden jar, a more dreadful shock than that which I experienced by imprudently placing both my feet on a gymnotus just taken out of the water."

The Torpedo. It would be difficult to name two fish more dissimilar in outward appearance than the Gymnotus and the Torpedo, and yet they enjoy in common the unique power of communicating electric shocks. The Gymnotus is a long eellike fish, the Torpedo is round and flat. The Torpedo belongs to the family of the Rays, and sometimes reaches a large size. It is common in the Mediterranean and is sometimes found on the southern coasts of the British Isles. 
"Although it has once or twice been caught on our coasts," says Mr. Wood, " it is usually found in the Mediterranean, where its powers are well known, and held in some awe. The shock that the Torpedo gives, of course, varies according to the size of the fish and its state of health, but a tolerably large fish in good health can, for the time, disable a strong man. From the effects of its shock, it is in some parts called the Cramp-fish. It has been known to weigh from seventy to a hundred pounds."

The Shark. The Shark, whose name instinctively suggests a shudder, is the largest of the fishes and one of the largest of marine animals. There are many varieties, and they are found in all seas; some measuring no more than a few feet, others attaining to very large proportions. The Blue Shark of the Mediterranean which measures about eleven feet sometimes approaches the south coast of England and Ireland, as does the Hammer-headed Shark of the Atlantic and the Indian Ocean, a shark of twelve feet in length. The Tope a smaller variety is often seen in the English Channel, as are also several others of the smaller Sharks. The Great Basking Shark which often measures thirty feet in the length is the largest of those which visit the English coast, but like the largest of all the sharks (Rhinodon Typicus) which sometimes exceeds fifty feet in length is herbivorous, and therefore not bloodthirsty.

The White The Shark known to sailors as the White Shark

sbark. is a fierce and sanguinary creature. It frequents the Atlantic Ocean and the Mediterranean Sea, where it follows ships for days for the sake of the refuse, which is thrown overboard. This creature has been known to swallow a man entire, and commonly to devour one in two or three portions. Sailors get no mercy from the shark and consequently show him none. There is a story told of a negro cook who seeing a shark follow in the wake of a ship made a brick hot in the stove, and then threw it to the monster who probably never had a warmer or more indigestible meal. This shark suffered 
great agony if its contortions may be taken as evidence, and, after exhausting itself with its fury, allowed itself to drift away with the tide. Expert swimmers, armed with long sharp knives, have sometimes engaged the shark single-handed, diving underneath it, and stabbing it before it discovered their whereabouts. The Negroes of the West Indies are credited with this hardihood, and are said to be frequently successful.

Sharks in

the South

Seas.

"The amphibious. South Sea Islanders," says Mr. Wood, " stand in great dread of the Shark, and with good reason, for not a year elapses without several victims falling to the rapacity of this terrific animal. Nearly thirty of the natives of the Society Islands were destroyed at one time by the sharks. A storm had so injured the canoe in which they were passing from one island to another, that they were forced to take refuge on a raft hastily formed of the fragments of their canoe. Their weight sunk the raft a foot or two below the surface of the water, and, dreadful to say, the sharks surrounded them and dragged them off the raft one by one, until the lightened raft rose above the water and preserved the few survivors." Mrs. Bowdich, who was an eye-witness of the tragic circumstances she describes, says :- "Sharks abounded at Cape Coast, and one day, as I stood at a window commanding a view of the sea, I saw some of the inhabitants of the town bathing, and the sharks hastening to seize upon them, - they being visible from always swimming with part of their dorsal fin out of water. I sent to warn the men of their danger, and all came ashore except one, who laughed at the caution of his companions. A huge shark was rapidly approaching, and I sent my servant again, and this time armed with half a bottle of rum, to bribe the man to save himself. It was too late, the murderous creature had seized him, and the water around was dyed with his blood. A canoe was dispatched to bring him ashore, but a wave threw him on to the beach; and it was found that the shark had taken the thigh bone completely out of the 
socket. The man, of course, expired in a very few minutes. Accidents were often happening, and always fatal, and yet the negroes, who seldom think beyond the present moment, could not be dissuaded from bathing. A man walking in the sea, up to his knees, was dragged away by one, almost before my eyes.' "

The Rays. The Rays are large flat fish of which there are numerous species, the Thornback and the Common Skate being the best known. They have large pectoral fins, and some species grow to an enormous size. The Skate has been known to measure six or seven feet. Other species are the Homelyn Ray and the Sandy Ray, which like the Thornback and the Skate are found in British waters. The Sting Ray and the Eagle Ray cover wider areas and grow to a gigantic size in tropic seas. It is a large species of the Eagle Ray that is known as the Sea Devil of the tropics. These fish, though very large, display no great antipathy to man, though from their enormous size and strength they are a source of danger to small craft. Mr. Swinburne Ward in a letter to Colonel Playfair, quoted in Dr. Percival Wright's concise "Natural History," thus describes the capture of one of these monsters off the Seychelles.

"Coming home we passed close to an enormous 'diabla de-mer' floating quietly about. We changed from the pirogue to the whale-boat, which I had scientifically fitted up for the gros poissons, and went alongside of him, driving a regular whale harpoon right through his body. The way he towed the water was beautiful, but we would not give him an inch of line and he also had to succumb to a rather protracted lancing. His size will give you an idea of his strength in the waterforty-two feet in circumference! We got him a wash on the beach, but the united strength of ten men could not get him an inch further, so we were obliged to leave him there. $\mathrm{By}$ this time the sharks will not have left much of him; they have not had such a meal as that for a long time. The fisher- 
men say that when alive the sharks do not molest the 'diablede-mer,' whose offensive weapons consist of those enormous flexible sides (one can hardly call them fins) with which they can beat almost any shark to death. As a rule when harpooned, they endeavour, like other rays, to bury themselves in the sand, and if they succeed in doing this, no line can ever haul them out of it-their flat bodies act on the principle of an enormous sucker. Another curious fact about them is that when harpooned they swim sideways, edge on, in order to avoid exposing too broad a surface to their enemy. They never do this unless harpooned."

Ray Catching. Lieutenant Lamont gave the following graphic description of a Ray fishing expedition in which he took part near Port Royal, Jamaica, in 1824 to Professor Jameson.

" The first appearance of an animal of this species, since I have been here (about eighteen months), was about two months ago, when I was called out to the beach by some of the inhabitants, whom I found, on going there, to be assembled in great numbers, to see what they called the Sea Devil. I confess my curiosity was not less excited than theirs, when I saw floating close to the surface of the water, about twenty yards from me, a large mass of living substance of a dark colour, but of the shape and size of which I could not, at the time, form any proper idea, it being so very different from what I had ever before seen or heard of, farther than that I supposed it to have been many times the size of what I now believe it was. No time was lost in setting out in pursuit of him, with harpoons, \&c.; and it was not long before he was come up with, and struck with one of the harpoons, when he made off with great velocity, towing the boat after him. As he seemed to incline chiefly to the surface of the water, six or seven more harpoons were (with the assistance of several canoes that had come up) successively plunged into him, and all the boats made fast to each other, which he was obliged to pull after him, with several people in each. Such, however, was 
the great strength of the animal, that, after being fast in the manner I have described, for upwards of nour hounrs, and taking the boats out to sea attached to him to a distance of about ten miles from the harbour, and having been pierced with so many wounds, he was still able to defy every effort to bring him in. It had now got late, and was dark, and an attempt was made to force him up near enough to get another large harpoon into him; this was no sooner done, than he darted off; and by an almost unaccountable and seemingly convulsive effort, in a moment broke loose from all fetters, carrying away with him eight or ten harpoons and pikes, and leaving every one staring at his neighbour in speechless astonishment, confounded at the power of the animal which could thus snatch himself from them at a time when they conceived him almost completely in their power.

"Since then some of these animals have occasionally been heard of at a distance from the harbour ; and a few days ago, in coming over from Fort Augusta with another gentleman, we fell in with one of them, which allowed us to get so near him, that it was determined to set out the next morning to look for him. We did so; and took with us several large harpoons, muskets, pikes, \&c., determined, if it were possible, to bring him in. He was described about eight o'clock near Greenwich, towards the top of the harbour, as usual floating near the surface, and moving slowly about. Having allowed the boat to get very close to him, he was struck with a harpoon, which was thrown at him in a most dexterous manner by Lieutenant St. John, of the royal artillery. He immediately set out towards the mouth of the harbour, towing the boat after him with such velocity, that it could not be overtaken by any of the others. After going on this way for near an hour he turned back, which enabled the other boats to lay hold; and four of them were tied, one after the other, to the one in which he was harpooned, with four or five people in each of them. By this means we hoped to tire him out the sooner. 
In about an hour and a half after he was first struck, a favourable opportunity offering, a large five-pointed harpoon, made fast to a very heavy staff, was thrown at him with such an elevation, that it should fall upon him with the whole weight of the weapon-this having been as well directed as the first, was lodged nearly in the middle of his back. The struggle he made at this time to get away was truly tremendous, - plunging in the midst of the boats, - darting from the bottom to the surface alternately, - dashing the water and foam on every side of him, -and rolling round and round to extricate himself from the pole. This might be considered as having given him the coup de grace, although, at short intervals afterwards, he was struck with two more harpoons, and several musket balls were fired into him. Still he was able to set out again, taking the four boats after him, which he carried along with the greatest ease. Having gone in this way for some time he came to a stop, and laid himself to the bottom, when, with all the lines that were attached to him, it was quite impossible to move him. All expedients were nearly beginning to fail, when it was proposed to slacken the lines, which being done had the desired effect, and he again set out. Having thus got him from the ground, inch by inch was gained upon him, till he was got near the surface, when he was struck with two large pikes. He now got rather faint; and the boats closing on him on every side, the combat became general with pikes, muskets, and every weapon we had. In fact, to such a pitch were all excited on the occasion, that, had a cool spectator seen the affray, he would undoubtedly have imagined that it was his sable majesty himself that we had got amongst us. $\mathrm{He}$ was now towed ashore, being about five hours since he was first struck. This it required all the boats to do, and then but very slowly. His appearance now showed the extraordinary tenacity of life of which this animal must be possessed, as his whole body was literally a heap of wounds, many of which were through and through, and he was not yet quite 
dead. This circumstance, with his great strength, is the cause of the name which has been given him by the fishermen here, as they have never been able to succeed in taking one of them, and were firmly of opinion it was impossible to do so.

" On measurement, it was found to be in length and breadth much the same, about fifteen feet, and in depth from three to four feet. It had the appearance of having no head, as there was no prominence at its mouth ; on the contrary, its exterior margin formed, as it were, the segment of a circle; with its arc towards the animal's body, and opening into a large cavity of about two feet and a half in width, without teeth, into which a man went with so much ease, that I do not exaggerate when I say, that another might have done so at the same time. On each side of the mouth projected a mass of cartilaginous substance like horns, about a foot and a half long, and capable of meeting before the mouth. These feelers moved about a great deal in swimming, and are probably of use in feeding. On looking on this animal as it lay on the ground with its back upwards, it might be said to be nearly equal in dimensions on every side, with the exception of the two lateral extremities, extending to a point about four feet from the body, and a tail about five feet long, four and a half inches diameter at the root, and tapering to a point. Above the root of the tail was the dorsal fin, and on each side of it a flat and flabby substance close to the body, of the appearance of fins. There were no other distinct fins, and its sole propelling power seemed to be its two lateral extremities, which became very flat and thin towards the point. As it shows these much in swimming, it gives a spectator an extraordinary idea of its size, as, to him imperfectly seen, the conclusion naturally is, if the breadth is so great, how much greater must the length be. This animal was a female, and was viviparous. On opening it, a young one, about twenty pounds weight, was taken out, perfectly formed, and which had been preserved. Wishing to know what it fed upon, I saw the stomach opened, which was round, 
about eight inches in diameter, and quite empty. It was closely studded over with circular spots of a muscular substance. Under the stomach was a long bag, with transverse muscular layers from end to end, and which contained nothing but some slime and gravel. This muscular appearance of the digestive organs would lead one to suppose that it fed upon other fish, as is the general opinion here, though its having no teeth does not support that idea. Its weight was so great that it was impossible to ascertain it at the time; but some idea may be formed of it when I assure you that it was with difficulty that forty men, with two lines attached to it, could drag it along the ground. Its bones were soft, and, with the exception of the jaw-bones, could be cut with a knife. One ridge of bone ran from the mouth to the middle of the back, where it was met by another running transversely, from the extremities of which there were two larger ones converging towards the tail." 


\section{N D EX.}

\section{A.}

Aardwolf, 80

Accentor modularis, 285

Accipitres, 250

Addax, 216

Aelurus fulgens, 145

African mouse, 227

“ owl [pigeon], 294

Agouti, 240

Aguara, 93, 94

Albatross, 316, 324

Alcephaline, 207

Alligator, 334, 335-337

Alpaca, 198

American blackbird, 253

“ bull frog, 352

“ horned owl, 313

“ house wren, 257

“ leopard, 64-67

“ lion, 43, 67-69

“ monkey, 30-32

" sable, i4o

“ vulture, 308

Anchovy, $35^{8}$

Angola or Angora cat, 7I

Anomalure, 237, 240

Anseres, 250

Ant-eater, 245, 247

Ant-thrush, 283

[bird], 250, 282

Antelope, 206, 216

Antilocaprina, 207
Anubis, 20

Anura, $35^{\circ}$

Ape, 3, 18, 29

Apteryx, 330

Arabian baboon, 20

" horse, 163-166

Arctic fox, 86, 93

Argus pheasant, 299

Armadillo, 245, 246

Artiodactyla, 162, 188

Ass, $162,178-183$

Ateles, 30

Australian hedgehog, 249

Aye-aye, 33, 34

B.

Babiroussa, I92

Baboon, I5, I9-25

Babouin, 20

Bactrian camel, 193

Badger, I40, 142

Bald eagle, 306

Balearic crane, 314

Bandicoot, 247

Barb [pigeon], 294

Barbary ape, 25

Barbel [sporting dog], 95

Barn owl, 3 r 3

Bat, 34-39

Bay antelope, 216

Beagle, 95, 129

Bear, 43, I45-I5I

[375] 
Bearded saki, 3I

Beaver, 226, 234-237

$$
\text { “ rat, } 227
$$

Bell bird, 25I, 283

Beluga catodon, 160

"Billybiter," 26r

Bird of Paradise, 25 $\mathrm{r}, 27 \mathrm{r}-273$

Bison, 162, 207, 211, 212

Bittern, 315

Black bear, I46, I47-I 49 :

$$
\begin{array}{ll}
\text { “ } & \text { grouse, 297 } \\
\text { “. } & \text { rat, 227 } \\
\text { “ } & \text { snake, 342 } \\
\text { “ } & \text { swan, 320 } \\
\text { “ } & \text { vulture, 309 }
\end{array}
$$

Black-necked swan, 320

Blackbird, 250, 252

Bladder-nose hooded seal, I55

Blenheim spaniel, I34, I35

Blood-hound, 95, 125-127

Blue jay, 263

$$
\text { " shark, } 366
$$

Boa constrictor, 340, 346-349

Boar, I62, Igo

Bobak, 240

Bonnet monkey, 25

Borèle, I84, 186

Bosch-bok, 216

Bovide, 206

Bovine, 207

Brahmin bull, 209

Brazilian porcupine, 24I

Brill, 357

Broodbill, 283

Brown bear, 146, I5I

$$
\text { " capuchin, } 30
$$

Budorcina, 207

Buffalo, 207, 213-216
Bull, 207, 208, 209

“ frog, 352

“ terrier, 136

Bull-dog, 95, 138

Bullifinch, 25I

Bunting, 251, 277

Bustard, 314

" Butcher bird," 262

Buzzard, 304, 3 II

o.

Cacilia, 350

Camel, I92-197

Camelopardalis giraffa, 205

Canadian porcupine, 24I

Canary, 25I, 276, 277

Canis anglicus, 138

" avicularis, 130

" domesticus, II4

"index, 132

" sanguinarius, 125

" scoticus, 123

Canvas-back duck, 3t9

Cape ant bear, 245, 246

“ buffalo, 214, 215

“ penguin, 326

Caprina; 207

Capuchin, 30

Capybara, 24I

Caribou, 20r-204

Carnivora, 43

Carp, 358

Carrier pigeon, 294, 295

Carrion crow, 251, 270

Cashmir goat, 217

Cassowary, 328, 329

Castor americanus, 235

“ gallicus, 235

Cat, 43, 44, 7I-76, 337

Catamountain, 43

Cavia aperea, 24I 
Cavia cobaya, 24I

Cavy, 240

Cayman, 336

Cebida. 3, 30- 32

Cephalophina, 207

Cercoleptes caudivolvulus, 145

Cervicaprince, 207

Cervus, I99

“ elaphus, I99

Chackma, 20, 21

Chaffinch, 275

Chameleon, 337,338

Chamois, 2 I6

Chatterer, 25 I, 282

Cheek-pouched monkey, rg

Cheir omyida, 33

Cheiramys madagascariensis, 33

Cheiroptera, 34

Chelonia imbricata, 333

Chetah, 77, 78

Chevrotain, 198

Chimpanzee, 3, 4, II, 12

Chinchilla, 226, 240

Chough, 25I, 262

Chub, $35^{8}$

Chuck-Will's-widow, 288

Civet, 79

Classical dolphin, I60

Clouded tiger, 70

Coach-dog, 95, 98

Coati, 145

Cobra, 340, 342-346

Cock of the rock, 282

Cockatoo, 290

Cod, 357

Colugo, 39

Columba, 250

Common barn owl, 314

“ crane, $3 \mathrm{I} 4$

“ duck, 3 I 9

، fin whale, I59
Common frog, 350, 352, 353

" gull, 32 I

“ hare, 241

“ iguana, 338

“ jay, 262

“ kingfisher, 287

“ lizard, 338, 339

" pheasant, 299

“ porpoise, I60, I6I

“ rabbit, 24I, 245

“ thea, 329

" seal, I55

“ skate, 368

is starling, 278

“ swan, 320

"s thrush, $25 x$

“ toad, 35 I

“ wren, 256, 257

Condor, 304, 308

Coney, 226

Conger eel, 362

Coot, 314

Coral snake, 349

Cormorant, 316, 323

Corvida, 262

Cotingide, 282

Couguar, 43,67

Cow, 207, 2 ro

Crake, 3 I4

Cramp-fish, 366

Crane, 3 I 4

Crocodile, I4, 334

Crossbill, 277

Crow, 262

Cuckoo, 284-286

Curlew, 3 I 4

Cyncelurus, 77

Cynocephalus, ro

D.

Dalmatian, 95,98 , 130 
Dama vulgaris, 204

Darwin's rhea, 329

Dasyure, 247

Deer, 27, 198-205

Delphinus Delphis, 160

Desman, 228

Dhole, 93, 94

Diable-de $\cdot m e r, 369$

Diana monkey, 19

Dingo, 93, 94

Dog, 43, 84, 94-r 39

Dolphin, $158,159,160$

Domestic fowl, 297, 302-304

$$
\text { “ turkey, 300-302 }
$$

Dormouse, 227, 233

Douroucouli, 32

Dove, 250

Dove-cot pigeon, 294

Drill, 20

Dromedary, I92, I93, I94

Duck, 3r6, 3 I9

Duck-billed platypus, 249

Dugong, 162

Duplicidentati, 226, 24I

\section{E.}

Eagle, 304, 305-307

$$
\text { “ ray, } 368
$$

Eared seal, I52

Eastern bison, 212

Echidnida, 249

Edible frog, 352

Eel, 358, 36I

Egyptian fox, 85

$$
\begin{array}{ll}
\text { ". hare, 24I } \\
\text { " vulture, } 308
\end{array}
$$

Eider duck, 3I9

Eland, 2I6

Electric eel, 362-366

Elephant, 27, 219-226

، tortoise, 332
Elk, 199, 204

Emballonurida, 36

Emu, 250, 328, 329, 330

English bunting, 277

“ carrier, 294

“ frill-back, 294

“ pouter, 294

“ terrier, 136

Entellus, I9

Equine antelope, 216

Ermine, I40

Esculent swift, 289

Eskimo dog, 104-I07

$\boldsymbol{F}$.

Falcon, 304, 311

Fallow deer, I99, 204

Fantail, 294

Fawn, 321

Feneca zaarensis, 85

Fennec, 85

Fern owl, 288

Ferret, 140

Fieldmouse, 227, 233

Finch, 275

Fish-hawk, 307

Fissipedia, 43

Fissirostres, 283

Flamingo, 314

Flounder, 357

Flying dog, 37

“ fish, $35^{8}, 360$

“ fox, 35

“ squirrel, 237

Four-horned antelope, 216

Fowl, 250, 297

Fox, 84, 85, 90-93, 337

Fox terrier, 136

Foxhound, 95, 128, 129

Frog, 350 
Galago, 33

Galline, 250, 297

Gavial, 334

Gazelle, 217

Gazelline, 207

Genet, 79

Gibbon, 3, I7, 18

Giraffe, 205, 206

Glutton, I40

Gnu, 2 I6

Goat, 206, 217

Goatsucker, 288

Golden eagle, 305

" howler, 31

4 oriole, 25I, 26 I

“ pheasant, 299

Golden-crested wren, 255, 256

Goldfinch, 25I, 275

Goose, 316-3I9

Gorilla, 3-I I

Goshawk, 304

Grallatores, 250

Grampus, I60, I6I

Great albatross, 324

“ ant-eater, 247

" auk, 3r6

“ basking shark, 366

“ black-backed gull, 32I, 323

"c eagle owl, 3I3, 3 I4

“ shrike, 262

“ titmouse, $26 \mathrm{r}$

Great-billed rhea, 329

Great-crowned pigeon, 294

Grebe, 316

Green monkey, I9

“ parrot, 290

“ turtle, 333

“ woodpecker, 284

Greenfinch, 275

Grey fox, 86
Grey parrot 290, 292

“ seal, I55

Greyhound, 95, I22-I24, 177

Griffin vulture, 307

Grivet, I9

Grizzly bear, 146, I49-I5 I

Ground parrot, 290

Grouse, 297

Guinea fowl, 297

Guinea-pig, 226, 241

Gull, 316, 321

Gulo luscus, 140

Gurnard, 354

Gymnotus, 358, 362-365

E.

Haddock, 357

Halibut, 357

Halicore dugong, 162

Hammer-headed shark, 336

Hamster, 228

Hapale, 32

Hare, 226, 241-244

Harnessed antelope, 216

Harp seal, 155, I56

Harrier, 95, I 29

Harvest mouse, 227, 233

Hatteria punctata, 337

Hawk, 73

Hawk's bill turtle, 333

Hedge-sparrow, 285

Hedgehog, 39

Hen, 176

Heron, 312, 3I4, 3I5

Herring, 358,360

Hinny, 183

Hippopotamus, 162, I88-rgo

Hippotragina, 207

Hoazin, 250, 304

Hog, 27, 28, rgo, 191 
Homelyn ray, 368

Honey bear, 146

Hook-billed ground pigeon, 294

Hoolock, 17,18

Hornbill, 287

Horse, $162-178$

Horseshoe bat, 36

House martin, 274

House mouse, 227. 232

Howling monkey, $3 \mathrm{I}$

Humming bird, 289

Humpback whale, 159

Hunting leopard, 77,78

tiger, 201

Hyana, 43, 80-84

Hyænidæ, 80

Hylobates, I7

Hyrax, 226

\section{I.}

Ibex, 218

Ichneumon, 79, 80

Iguana, $\mathbf{3 3 8}$

Imperial eagle, 305

Indian buffalo, 213

“ frillback, 294

" monkey, 25-29

“ rhinoceros, 184

" tapir, 184

Indri, 33

Insectivora, 39

Irish hare, 241

Ivory gull, $32 \mathrm{I}$

Ivory-billed woodpecker, 284

Izard, 216

\section{J.}

Jack, 359

Jack screamer, 289

Jackal, 27, 28, 84, 86

Jackass penguiin, 326
Jackdaw, 25I, 272

Jacobin, 294

Jagliar, 43, 64-67 :

Jay, 251, 262

Jerboa, 226, 234

Jungle fowl, 297

Kahan, I9

Kangaroo, 247, 248

Keitloa, I84

Kestrel, 304

King bird, 25I, 282

King Charles spaniel, 120, 134, 135

" duck, 319

" of the vultures, 308

“ penguin, 326

Kingfisher, 287

Kinkajou, 145

Kit fox, 86

Kite, 304, 3II

Kobaoba, I84

L.

Labrador dog, 107

Land bear, 146

Lapwing, 314

Lark, 25I, 258, 279-28r

Laugher, 294

Laughing kingfisher, 287

Leathery turtle, 334

Leech, 355

Lemming, 227, 228

Lemux, 3, 32, 33

Lemuride, 32, 33

Leopard, 43, 6I-64

Lesser fin whale, 159

Leucocyon lagopus, 86

Leucoryx, 216

Linnet, 25I, 276

Lion, 43, 44-57 
Little ant-eater, 247

Lizard, 337

Llama, 198

$$
\begin{aligned}
& \text { “ pacos, } 198 \\
& \text { “ peruana, } 198 \\
& \text { " vicugna, } 198
\end{aligned}
$$

Loggeshead turtle, 334

Long-eared owl, 313

Long-nosed dolphin, I60 “ monkey, I9

Long-tailed duck, 319

$$
\begin{array}{ll}
\text {." } & \text { manis, 246 } \\
\text { a } & \text { sheep, 2r7 } \\
\text { titmouse, 26r }
\end{array}
$$

Love bird, 290

Lurcher, 124

Lutra vulgaris, $\mathbf{1 4 I}$

Lynx, 44, 76, 77

Lyre bird, 250, 25I, 283

\section{M.}

Macacus, 25

Macagne, 25

Macaw, 290

Mackerel, 354, 356

Magot, 25

Magpie, 251, 262, 264-266

Mahoohoo, 184

Malayan bear, I46, I5I

Malbrouck monkey, 19

Mallard, 319

Maltese spaniel, 134, I35

Manakin, 25I

Manatide, 162

Mandarin, 3I9

Mandrill, 20

Manis, 246

Manx Cat, 71

Marmoset, 3, 32

Marmot, 237, 240

Marsh Harrier, 3II
Martin, 25I, 274, 275

Mastiff, 95, 109, $136-138$

Meadow pipit, 282

Megaderma Lyra, 36, 38

Meles taxus, $\mathbf{1 4 2}$

Mellivora capensis, $\mathbf{1 4 3}$

Merino, 217

Mias, 3, 13, I4

Midas, 32

Missel thrush, 252

Mississippi alligator, 335

Mocking bird, 250, $25+$

Mole, 39-42

Mona, I9

Monitor, 337, 339

Monkey, 3, I5, 18-32

Monodon monoceros, I6o

Monotremata, 249

Moor hen, 314

Moose, I99, 204, 227

Mother Carey's chicken, 322

Mountain hare, 24r

Mouse, 226, 227, 232, 233

Mouse deer, 198

Muchocho, 184

Mule, 183

Mullet, 354

Muscovy duck, 3 I9

Musk rat, 227

" sheep, or ox, 217

Mustelida, I4O

Mycetes, 3 I

N.

Narwhal, I6o

Nasua narica, 145

Nemorhedina, 207

Newfoundland dog, 95, 97, 98, I0r, I07-II4, I77

Newt, 350

Nicobar pigeon, 294

Night-jar, 288 
Nightingale, 250, 258, 259

Nile monitor, 339

Nine-killer, 262

Northern sea bear, I52, 154

$$
\text { “ " lion, } 152
$$

Numidian crane, 314

Nun, 294

Nycterida, 36

Nycticebus tardigradus, 33

Nyctipithecus felinus, 32

Nylghan, 216

\section{o.}

Ocelot, 69

Opisthocomi, 250

Opossum, 247

Orang-utan, 3, 12-17

Orca gladiator, $\mathbf{3 6 \mathbf { I }}$

Organist tanager, 273

Ornithorhynchida, 249

Orygina, 207

Osprey, 3II

Ostrich, 250, 328, 329

Otarida, 152

Otter, I4O, I4I, 142

Ounce, 43, 20r

Oven bird, 283

Owl, 304, 313

Ox, 162, 206, 207, 209

\section{P.}

Pallah, 216

Panda, 145

Pangolin, 245, 246

Panther, 43, 6r-64, 67

Paradisea apoda, 27I-273

Paradoxure, 79

Parrakeet, 290

Parrot, 250, 290-294

Partridge, 299

Passenger pigeon, 294
Passeres, 250

Patas, I9

Pea-fowl, 298

Peacock, 297, 298

“ pheasant, 298

Peahen, 298

Peccary, I9O, Ig2

Pelican, 3I6, 325

Penguin, 316, 326

Perch, 354

Peregrine falcon, 3 II

Perissodactyla, 162

Persian cat, 7r

Persian lynx, 44

Petrel, 316

Pheasant, 297, 298

Philander, 247

Phyllostomida, 36

Picarice, 250

Pied wagtail, 28I

Pig, Igo

Pigeon, 294-297

Pike, 358,359

Pine marten, 140

Pinnipedia, 43, I5I

Pipistrelle, 36

Pipit, 251, 28I

Pithecia, 3I

Plaice, 357

Plantcutter, 283

Platypus, 249

Plecotus auritus, 36

Plover, 3I4

Pointer, 95, 130-r 32

Polar bear, I46, I57

". hare, 24I

Polecat, 140

Poodle, IOI, I 39

Porcupine, 226, 240, 241

Porpoise, I6I

Pouched rat, 227, 228 
Prairie dog, 237, 240 " grouse, 297

Procyonido, 145

Prong-horned antelope, 216

Protelida, 80

Pseudophidia, 350

Psittacini, 250

Ptarmigan, 297

Puffin, 316, 323, 327

Puma, 43, 67-69

Python, I4

Quagga, I83

Quail, 297

R.

Rabbit, 226, 24I, 245

Raccoon, I45

Rana temporaria, 352

Rat, 226, 227-232, 303

“ kangaroo, 246

Ratel, I43

Rattlesnake, 340, 34I, 342

Raven, 25I, 264, 266-269

Ray, 365, 368-373

Red deer, I99, 201

Red fox, 86

$$
\text { " grouse, } 297
$$

Red-backed shrike, 262

Red-headed woodpecker, 284

Reindeer, 199, 20I-204

Resplendent trogon, 287

Rhea, 328, 329

Rhesus monkey, 25

Rhinoceros, $162,184-188$

$$
\text { “ bird, I9o }
$$

Rhinodon Typicus, 366

Right whale, 158

Ringed seal, 155

Roach, 358

Robin, 250, 259, 260

Rock manakin, 282
Rodents, 226

Roebuck, I99, 204

Rook, 25I, 270

Runt, 294

Rupicaprina, 207

Rupicola elegans, 282

s.

Sable, 140

Sacred monkey, 18

Sage hare, 24I

St. Bernard dog, I I9-122

Salamander, 350

Salmon, 358

Sand lizard, 338

Sandmartin, 275

Sandpiper, 314

Sandy ray, 368

Sardine, 358

Sardinian hare, 24I

Scansores, 283

Scarlet tanager, 273

Scotch greyhound, 123

“ terrier, I36

Scrub bird, 250, 25I, 283

Sea bear, 145

“ canary, 160

“ cow, 162

“ devil, 368-373

“ elephant, 155, I56

“" leopard, 155

"lion, 43, 152

“ pig, I60

Sea-gull, 321

Seal, $43,15 I-158$

Secretary bird, 3 Io

Semnopithecus, I8, I9

Serval, 44, 70

Setter, 95, r32-134

Shark, $366-368$

Sheep, 162, 206, 217-219 
Sheldrake, 3ro

Shepherd's dog, 95, 99, II4-I I9

Short-faced tumbler, 294

Short-tailed manis, 246

Shrew, 39, 42, 43

Shrike, 262, 282

Siamang, 3, I7, 18

Siberian dog, 107

Silver fox, 86

Simia, 12

Simplicidentati, 226

Skate, 368

Skunk, I43-I45

Skye terrier, I36

Sky-lark, 258, 279-28 r

Sleuth-hound, 125

Sloth, 245

Sloth bear, I5I

Slow lemur, 33

Snakes, 339-349

Snipe, 314

Snow bunting, 277

Sociable weaver-bird, 278

Sole, 357

Sorex vulgaris, 42

Spaniel, 95, 98, Ior, $134-136$

Sparrow-hawk, 302, 304, 312

Spectacled bear, I5I

Sperm whale, I59

Sphinx, 2o

Spider monkey, 30

Spot, 294

Spotted eagle, 305

Spotted hyæna, 82, 83

Squirrel, 226, 237-239

Stag, I99-20I

Staghound, 127

Starling, 250, 25I, 278

Stickleback, 354-356

Sting ray, 368

Stoat, 140
Stork, 3I4, 3I5, 316

Stormy petrel, 322, 323

Striped hyæna, 82

Struthionies, 250

Sturmide, 278

Sulphur-crested cockatoo, 290

Swallow, 251, 273, 274

“ [pigeon], 294

Swan, 316, 319-32I

Swift, 289

Sword-fish, 354, $35^{6}$

Syrian bear, I5I

\section{T.}

Tadpole, $35^{\circ}$

Tahaleb, 85

Tailor bird, 250, 255

Tanager, 250, 273

Talapoin, 19

Talpida, $4^{\circ}$

Tapir, 183

Tapirida, 183

Tarsida, 33

Tarsier, 33

Tarsius spectrum, 33

Teal, 3I6, 3I9

Terrier, 95, 96, 136

Thick-headed shrike, 262

Thistlefinch, 275

Thornback, 368

Thrush, 250, 25I, 286

Tiger, 43, 57-6I

Tiger-cat, 43

Titmouse, 250, 260

Toad, 350-352

Tomtit, 26r

Tope, 365

Torpedo, 365

Tortoise, 33I

Tragelaphina, 207

Tragulus, 198 
Tragulus meminna, I98

Tree frog, 350, 353

" kangaroo, 248

" pipit, 282

“ porcupine, 24I

Trichechus rosmarus, 154

Troglodytes, 4

Trogon, 287

Trout, $35^{8}$

Trumpeter, 294

Turbot, 357

Turkey, 300-302

Turnspit, 130

Turtle, 65, 331, 333

Tyrannida, 282

Tyrant fly-catcher, 282

“ shrike, 282

U.

Umbrella bird, 25I, 283

Unicorn, I85

Urodela, 350

Ursus americanus, 147

"arctos, $15 \mathrm{I}$

v.

Vampire bat, 36-39

Vervet monkey, I9

Vespertilionida, 36, 38

Viper, 340

Viscacha, 240

Viverrida, 79

Vulpes vulgaris, 85

Vulture, 304, 307-310

\section{w.}

Wagtail, 253, 28I

Wallachian sheep, 217

Walrus, 43, I5I, I54
Wanderoo, 25

Water rat, 227

Water shrew, 42

Water spaniel, 134, I35

Water-pheasant, 314

Weasel, 43, 140

Weaver bird, 25I, 278

Weeper capuchin, 30

Whale, I58, 159

Whip-poor-Will, 288

White shark, 367

White whale, r6o

White-headed sea eagle, 305, 306

White-nosed monkey, Ig

White-throated capuchin, 30

Whooping swan, 320

Widgeon, 319

Wild boar, Igo

“cat, 7o, 7I

" dog, 93

" goose, 3 I 7

“ turkey, 297, 300

Wild-duck, 3I9

Wildebeest, 216

Willow wren, 256

Wolf, 43, 84, 85, 86-9o

Wombat, 247

Woodchuck, 240

Woodcock, 314

Woodpecker, 282, 284

" Wool man," 248

Wren, 250, 255-258

Wryneck, 284

\section{$\mathbf{Y}$.}

Yak, 216

\section{z.}

Zebra, 183

Zebu, 216 
Digitized by Microsofte 
Digitized by Microsofte 
Digitized by Microsofte 


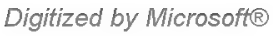




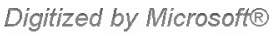




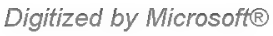


